Prepared in Cooperation with the Honolulu Board of Water Supply

\title{
Effects of Surface-Water Diversion and Ground-Water Withdrawal on Streamflow and Habitat, Punaluu Stream, Oahu, Hawaii
}

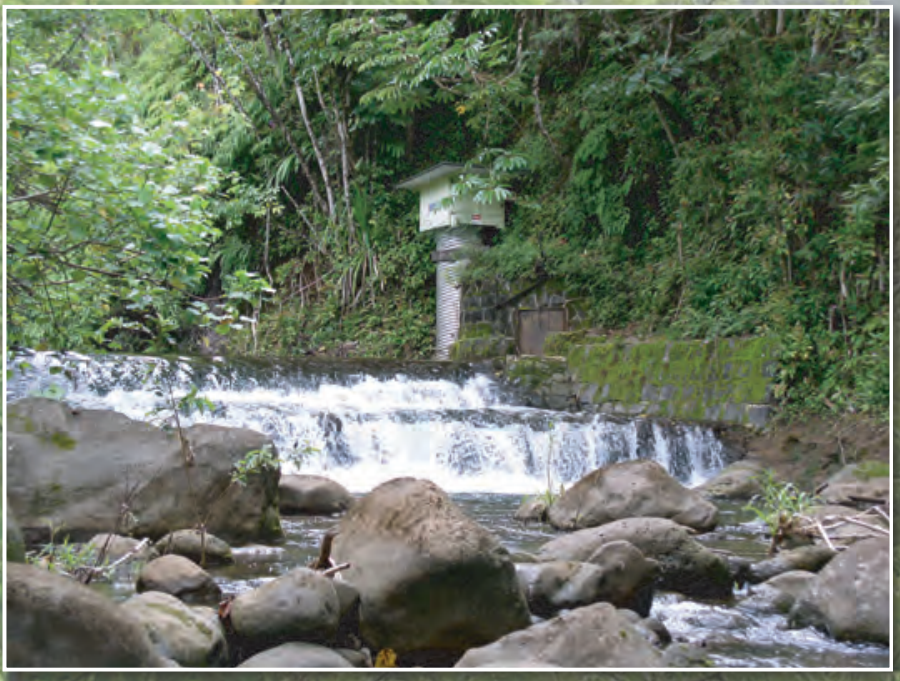

Scientific Investigations Report, $2006-5153$, है ?

U.S. Deparinent of the linterior

U.S. Goologjtoaf Sunney 
About the cover: Punaluu Stream flows perennially because of ground-water discharge and persistent rainfall over the mountainous interior areas of the watershed (background photo). The U.S. Geological Survey records flow in Punaluu Stream at an altitude of about 210 feet (gaging station 16303000 shown in upper left inset) as well as in Punaluu Ditch (gaging station 16302000 in lower right inset). Punaluu Ditch diverts water from Punaluu Stream and consists of a system of 12 tunnels connected by open ditches. The portal to the first of the 12 tunnels of Punaluu Ditch is visible in the upper left inset just downstream from the gage house at station 16303000 . Water flowing out of the first tunnel is measured at gaging station 16302000 . 


\section{Effects of Surface-Water Diversion and Ground-Water Withdrawal on Streamflow and Habitat, Punaluu Stream, Oahu, Hawaii}

By Delwyn S. Oki, Reuben H. Wolff, and Jeff A. Perreault

Prepared in Cooperation with the Honolulu Board of Water Supply

Scientific Investigations Report 2006-5153 


\section{U.S. Department of the Interior \\ Dirk Kempthorne, Secretary \\ U.S. Geological Survey \\ P. Patrick Leahy, Acting Director}

\section{U.S. Geological Survey, Reston, Virginia: 2006}

For product and ordering information:

World Wide Web: http://www.usgs.gov/pubprod

Telephone: 1-888-ASK-USGS

For more information on the USGS--the Federal source for science about the Earth, its natural and living resources, natural hazards, and the environment:

World Wide Web: http://www.usgs.gov

Telephone: 1-888-ASK-USGS

Any use of trade, product, or firm names is for descriptive purposes only and does not imply endorsement by the U.S. Government.

Although this report is in the public domain, permission must be secured from the individual copyright owners to reproduce any copyrighted materials contained within this report.

Suggested citation:

Oki, D.S., Wolff, R.H., and Perreault, J.A., 2006, Effects of Surface-Water Diversion and Ground-Water Withdrawal on Streamflow and Habitat, Punaluu Stream, Oahu, Hawaii: U.S. Geological Survey, Scientific Investigations Report 2006-5153, $104 \mathrm{p}$. 


\section{Contents}

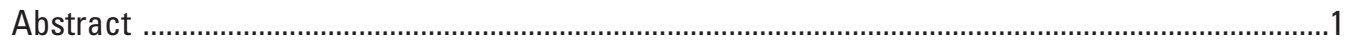

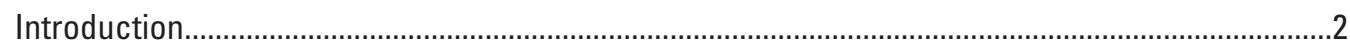

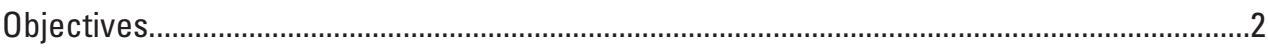

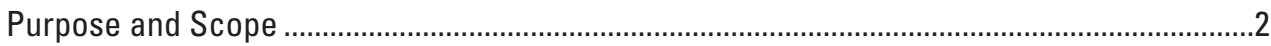

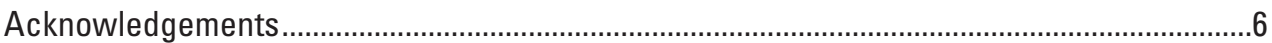

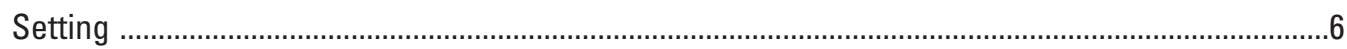

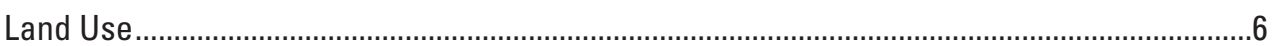

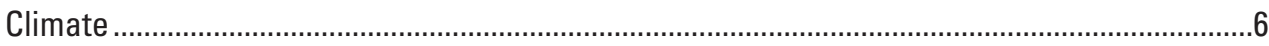

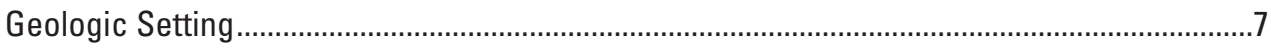

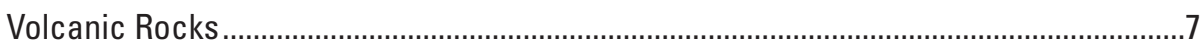

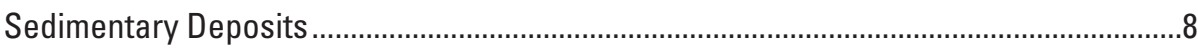

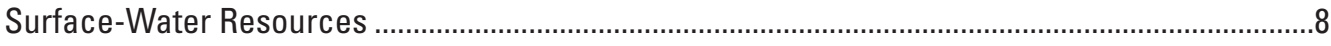

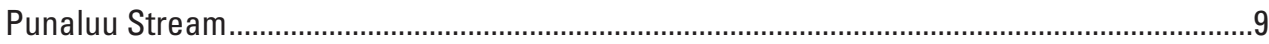

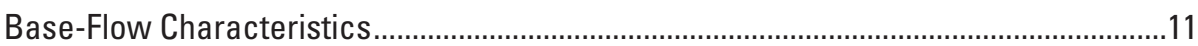

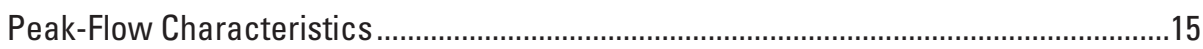

Interaction Between Ground Water and Surface Water .......................................................17

Gains and Losses Below an Altitude of 210 Feet.........................................................18

Seepage Runs and Additional Discharge Measurements............................................18

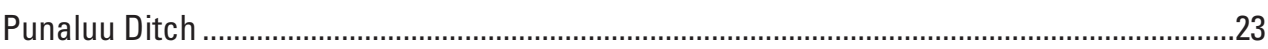

Punaluu Ditch Flow Characteristics ................................................................................

Ditch Discharge Measurements .....................................................................................24

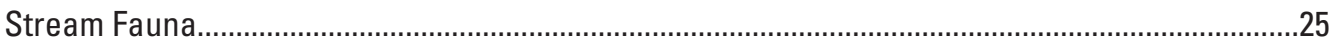

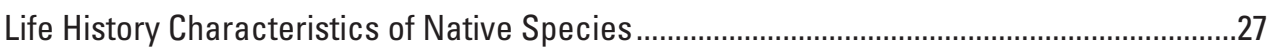

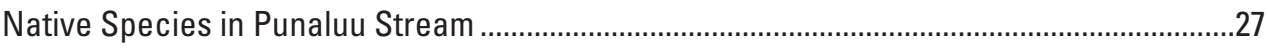

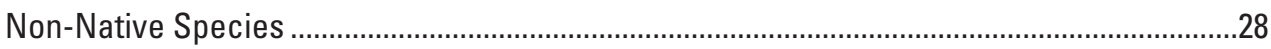

Potential Factors Affecting Abundance of Native Species ........................................................3

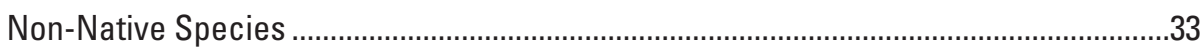

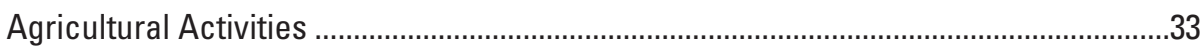

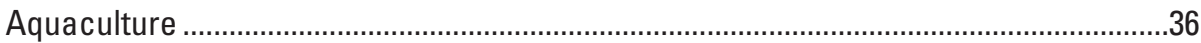

Effects of Surface-Water Diversion on Streamflow ................................................................36

Immediately Downstream from Punaluu Ditch Diversion (210-Feet Altitude) ........................36

Altitudes of 140 to 10 Feet................................................................................................

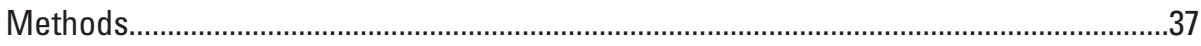

Flow Characteristics for Diverted Conditions .................................................................38

Flow Characteristics for Natural Conditions .................................................................38

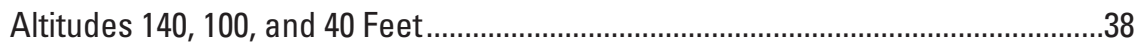

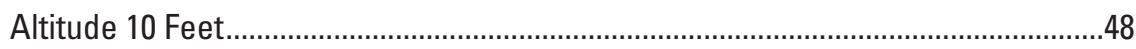

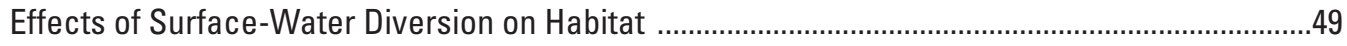

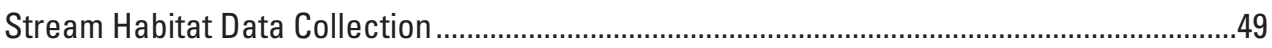

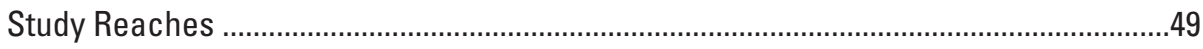

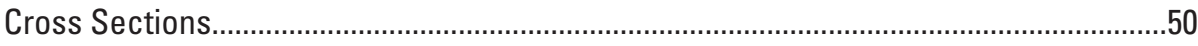

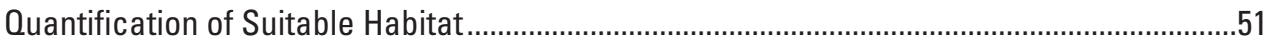


Habitat-Duration Characteristics .......................................................................................53

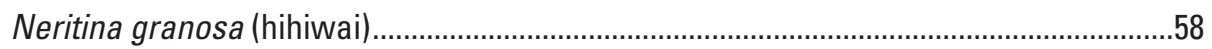

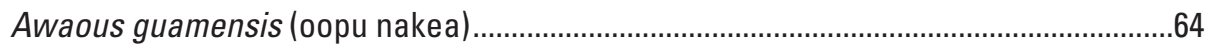

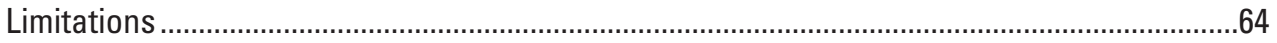

Effects of Surface-Water Diversion on Stream Temperatures .....................................................66

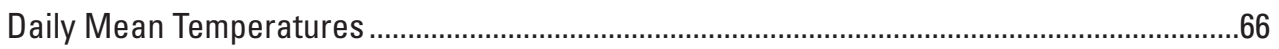

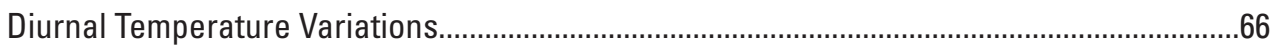

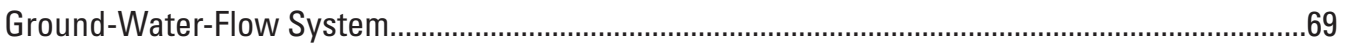

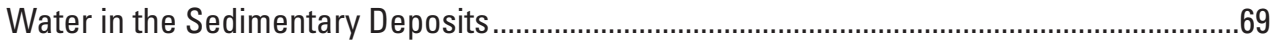

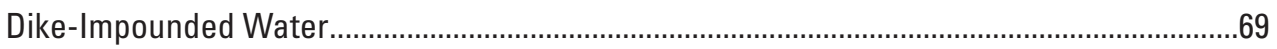

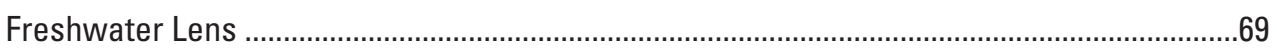

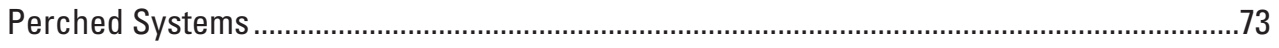

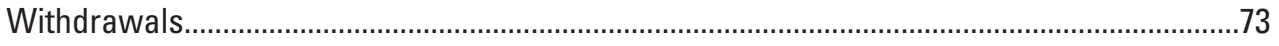

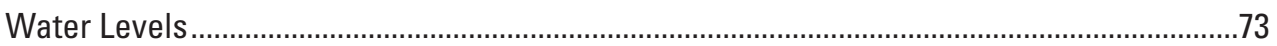

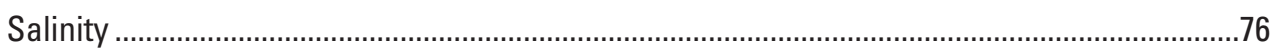

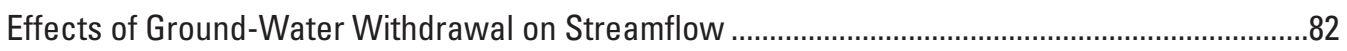

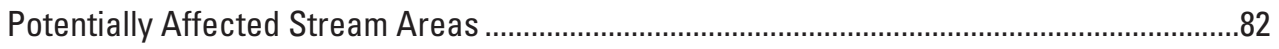

Water-Level Variations Caused by Withdrawal...................................................................... 84

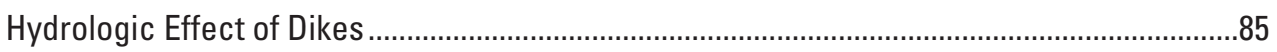

Approaches to Quantify Streamflow Reduction ................................................................. 86

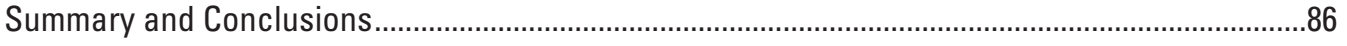

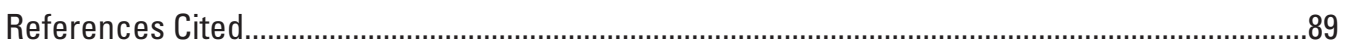

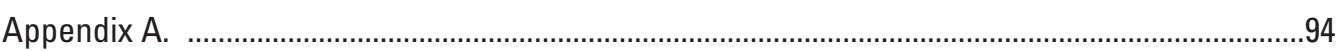

Table 1. Discharge measurements made during 2004 and 2005 in Punaluu Ditch and

Punaluu Stream and tributaries, Oahu, Hawaii, sorted by date.

Table 2. Discharge measurements made during 2004 and 2005 in Punaluu Ditch and

Punaluu Stream and tributaries, Oahu, Hawaii, sorted by site. 100

\section{Figures}

1. Punaluu study area and mean annual rainfall, Island of Oahu, Hawaii

2. Topographic map of Punaluu study area and selected stream- and rain-gaging stations, Oahu, Hawaii.

3. Geologic features and wells in the Punaluu area, Oahu, Hawaii .....................................5

4. Mean monthly rainfall at selected rain-gaging stations near Punaluu, Oahu, Hawaii.....7

5. Water-level drawdown in well 3553-01 caused by withdrawal from well 3553-03 at a rate of 2,100 gallons per minute, Punaluu, Oahu, Hawaii.................................................9

6. Geologic cross sections, Punaluu, Oahu, Hawaii .......................................................10

7. Flow-duration curves for Punaluu Stream (gaging stations 16299000 and 16301000) for water years 1916 and 1917, Oahu, Hawaii

8. Annual mean discharge in Punaluu Stream (gaging stations 16303003 and 16303000) and Punaluu Ditch (gaging station 16302000), Oahu, Hawaii.

9. Mean monthly discharge in Punaluu Stream (gaging stations 16303003 and 16303000) and Punaluu Ditch (gaging station 16302000) during water years 1955-2004, Oahu, Hawaii 
10. Flow-duration curves for Punaluu Stream total flow, base flow, and direct runoff (gaging station 16303003), water years 1955-2004, Oahu, Hawaii..

11. Discharge in Punaluu Ditch (gaging station 16302000), Punaluu Stream (gaging station 16303000), and combined discharge from stations 16302000 and 16303000 (gaging station 16303003), August 2004, Oahu, Hawaii.

12. Probability of peak discharge being equaled or exceeded during any given year at Punaluu Stream (gaging station 16303000), Oahu, Hawaii...

13. Discharge at selected altitudes, Punaluu Stream, Oahu, Hawaii

14. Sites of discharge measurements on Punaluu Stream and tributaries and Punaluu Ditch, Oahu, Hawaii, 2004 and 2005

15. Streamflow variation with stream-channel altitude below 210 feet, Punaluu Stream, Oahu, Hawaii .....

16. Streamflow variation (excluding measured tributary inflows and ditch return flows downstream from an altitude of $210 \mathrm{ft}$ ) with stream-channel altitude, Punaluu Stream, Oahu, Hawaii

17. Flow-duration curves for Punaluu Ditch (gaging station 16302000), Punaluu Stream (gaging station 16303000), and combined discharge from stations 16302000 and 16303000 (gaging station 16303003), water years 1995-2004, Oahu, Hawaii..

18. Photographs of the Punaluu Ditch intake near a stream altitude of about 210 feet on August 5,2005 , (A) prior to clearing the intake grate of debris and (B) after clearing the intake grate of debris

19. Native species observed in Punaluu Stream during 2004 and 2005, Oahu, Hawaii ...

20. Non-native species observed in Punaluu Stream during 2004 and 2005, Oahu, Hawaii

21. Flow-duration curves for Punaluu Stream (gaging station 16303003) for water years 1955-2004 and 1995-2004, Oahu, Hawaii

22. Flow-duration curves for low-flow partial-record stations at altitudes of 10, 40, 100, and 140 feet, Punaluu Stream, Oahu, Hawaii

23. Ratios of diverted-to-natural discharges $\left(\mathrm{O}_{50}\right.$ and $\left.\mathrm{O}_{95}\right)$ at stream-channel altitudes of 10 to 200 feet, Punaluu Stream, Oahu, Hawaii.

24. Habitat-suitability curves (Froude number) for selected native species, Hawaii ...........52

25. Relation between habitat (weighted usable area) for selected native species and discharge at an altitude of 10 feet (reach 1), Punaluu Stream, Oahu, Hawaii..

26. Relation between habitat (weighted usable area) for selected native species and discharge at an altitude of $\mathbf{4 0}$ feet (reach 2), Punaluu Stream, Oahu, Hawaii.....

27. Relation between habitat (weighted usable area) for selected native species and discharge at an altitude of 100 feet (reach 2b), Punaluu Stream, Oahu, Hawaii

28. Relation between habitat (weighted usable area) for selected native species and discharge at an altitude of 200 feet (reach 3), Punaluu Stream, Oahu, Hawaii

29. Habitat-duration curves for study reaches at altitudes of 10,40 , and 100 feet, Punaluu Stream, Oahu, Hawaii..

30. Habitat-duration curves for the study reach at an altitude of 200 feet, Punaluu Stream, Oahu, Hawaii

31. Relation for Neritina granosa (hihiwai) between diversion condition and habitat (in terms of change in weighted usable area relative to natural conditions), Punaluu Stream, Oahu, Hawaii

32. Relation for Awaous guamensis (oopu nakea) between diversion condition and habitat (in terms of change in weighted usable area relative to natural conditions), Punaluu Stream, Oahu, Hawaii 
33. Relation for Neritina granosa (hihiwai) between diversion condition and average number of days per year that habitat is less than 50 or 75 percent of the habitat at median natural discharge, Punaluu Stream, Oahu, Hawaii.

34. Relation for Awaous guamensis (oopu nakea) between diversion condition and average number of days per year that habitat is less than 50 or 75 percent of the habitat at median natural discharge, Punaluu Stream, Oahu, Hawaii.

35. Daily mean discharge at stream-gaging station 16303003 , daily mean stream temperatures at altitudes of 10 to 210 feet above mean sea level, and daily mean temperature difference between stream altitudes of 210 and 10 feet, Punaluu Stream, Oahu, Hawaii

36. Discharge at stream-gaging station 16303003 , stream temperatures at altitudes of 10 and 210 feet above mean sea level, and difference between daily maximum and minimum stream temperatures, Punaluu Stream, Oahu, Hawaii..

37. Schematic cross section showing freshwater-lens system and dike-impounded ground water, Punaluu, Oahu, Hawaii

38. Schematic cross sections of (A) gaining stream with sedimentary deposits hydraulically connected to the volcanic rocks, (B) losing stream with sedimentary deposits hydraulically connected to the volcanic rocks, and (C) losing stream with saturated sedimentary deposits separated from the volcanic rocks by a zone of unsaturated rock

39. Fluid specific-conductance profiles from Punaluu deep monitor well 3553-05, 0ahu, Hawaii...

40. Ground-water withdrawal from Punaluu well fields I, II, and III, Oahu, Hawaii ..............74

41. Measured ground-water levels on April 12, 2005 and May 19, 2005 in the Punaluu area, Oahu, Hawaii

42. Ground-water levels in Punaluu wells VA (3454-01) and VB (3453-10) during May 15 through July 31, 2005, Oahu, Hawaii.

43. Ground-water levels in Punaluu deep monitor well 3553-05, Punaluu, Oahu, Hawaii

44. Discharge at Punaluu Stream gaging station 16303003 and water levels in Punaluu well VB (3453-10) and Makalii well 3 (3453-13), Oahu, Hawaii, April 15, 2005 through May 15, 2005

45. Water levels in Sproat well (3453-05), water levels with tidal variations removed, and pump timing at selected wells in the Punaluu area (shaded areas represent periods when pumps were in operation), Oahu, Hawaii, during June 2005

46. Water levels in Makalii 1 (3452-02), water levels with tidal variations removed, and pump timing at selected wells in the Punaluu area (shaded areas represent periods when pumps were in operation), Oahu, Hawaii, during June 2005

47. Water levels in Makalii 3 (3453-13), water levels with tidal variations removed, and pump timing at selected wells in the Punaluu area (shaded areas represent periods when pumps were in operation), Oahu, Hawaii, during June 2005

48. Water levels in Punaluu VA (3454-01), water levels with tidal variations removed, and pump timing at selected wells in the Punaluu area (shaded areas represent periods when pumps were in operation), Oahu, Hawaii, during June 2005

49. Chloride concentration of pumped water from Punaluu well fields I, II, and III, Oahu, Hawaii

50. Stage-discharge relation for Punaluu Stream near an altitude of 10 feet, Oahu, Hawaii, 2004-2005.

51. Double-mass curves of cumulative base flows in Punaluu Stream (gaging station 16303003) and (A) Kalihi Stream (gaging station 16229000), (B) North Fork Kaukonahua Stream (gaging station 16200000), Oahu, Hawaii. 


\section{Tables}

1. Discharge measurements made during 2004 and 2005 in Punaluu Ditch and Punaluu Stream and tributaries, Oahu, Hawaii, sorted by date

2. Discharge measurements made during 2004 and 2005 in Punaluu Ditch and Punaluu Stream and tributaries, 0 ahu, Hawaii, sorted by site

3. Rainfall during the 24- and 72-hour periods prior to 8:00 a.m. on the days of seepage-run measurements, Punaluu Stream, Oahu, Hawaii.

4. Native aquatic species observed in Punaluu Stream, 1969-2004, Oahu, Hawaii ............29

5. The distributions and abundances of native aquatic species observed in Punaluu Stream in 2004

6. Non-native aquatic species observed in Punaluu Stream from surveys during 1984 to 2004

7. The distributions and abundances of non-native aquatic species observed in Punaluu Stream in 2004

8. Concurrent discharge values at the low-flow partial-record station at a stream altitude of 10 feet and at gaging stations 16303000 and 16303003, Punaluu Stream, Oahu, Hawaii

9. Concurrent discharge values at the low-flow partial-record station at a stream altitude of 40 feet and at gaging stations 16303000 and 16303003, Punaluu Stream, Oahu, Hawaii ..

10. Concurrent discharge values at the low-flow partial-record station at a stream altitude of 100 feet and at gaging stations 16303000 and 16303003, Punaluu Stream, Oahu, Hawaii ...

11. Concurrent discharge values at the low-flow partial-record station at a stream altitude of 140 feet and at gaging stations 16303000 and 16303003, Punaluu Stream, Oahu, Hawaii ..

12. Estimated flow-duration characteristics for natural and recent diverted conditions for the low-flow partial-record station at a stream altitude of 10 feet, Punaluu Stream, Oahu, Hawaii

13. Estimated flow-duration characteristics for natural and recent diverted conditions for the low-flow partial-record station at a stream altitude of 40 feet, Punaluu Stream, Oahu, Hawaii

14. Estimated flow-duration characteristics for natural and recent diverted conditions for the low-flow partial-record station at a stream altitude of 100 feet, Punaluu Stream, Oahu, Hawaii

15. Estimated flow-duration characteristics for natural and recent diverted conditions for the low-flow partial-record station at a stream altitude of 140 feet, Punaluu Stream, Oahu, Hawaii

16. Percentage of riffle, run, and pool habitat within selected study reaches, Punaluu Stream, Oahu, Hawaii

17. Substrate size categories and dominant substrate suitability values for selected native species 


\section{Conversion Factors}

\begin{tabular}{|c|c|c|}
\hline Multiply & By & To obtain \\
\hline \multicolumn{3}{|c|}{ Length } \\
\hline inch (in.) & 25.4 & millimeter (mm) \\
\hline foot $(\mathrm{ft})$ & 0.3048 & meter $(\mathrm{m})$ \\
\hline mile (mi) & 1.609 & kilometer $(\mathrm{km})$ \\
\hline \multicolumn{3}{|c|}{ Area } \\
\hline square foot $\left(\mathrm{ft}^{2}\right)$ & 0.09290 & square meter $\left(\mathrm{m}^{2}\right)$ \\
\hline square mile $\left(\mathrm{mi}^{2}\right)$ & 259.0 & hectare (ha) \\
\hline square mile $\left(\mathrm{mi}^{2}\right)$ & 2.590 & square kilometer $\left(\mathrm{km}^{2}\right)$ \\
\hline \multicolumn{3}{|c|}{ Volume } \\
\hline gallon (gal) & 3.785 & liter $(\mathrm{L})$ \\
\hline gallon (gal) & 0.003785 & cubic meter $\left(\mathrm{m}^{3}\right)$ \\
\hline million gallons (Mgal) & 3,785 & cubic meter $\left(\mathrm{m}^{3}\right)$ \\
\hline cubic foot $\left(\mathrm{ft}^{3}\right)$ & 0.02832 & cubic meter $\left(\mathrm{m}^{3}\right)$ \\
\hline \multicolumn{3}{|c|}{ Flow rate } \\
\hline foot per second (ft/s) & 0.3048 & meter per second $(\mathrm{m} / \mathrm{s})$ \\
\hline cubic foot per second $\left(\mathrm{ft}^{3} / \mathrm{s}\right)$ & 0.02832 & cubic meter per second $\left(\mathrm{m}^{3} / \mathrm{s}\right)$ \\
\hline gallon per minute (gal/min) & 0.06309 & liter per second $(\mathrm{L} / \mathrm{s})$ \\
\hline million gallons per day (Mgal/d) & 0.04381 & cubic meter per second $\left(\mathrm{m}^{3} / \mathrm{s}\right)$ \\
\hline \multicolumn{3}{|c|}{ Mass } \\
\hline ounce, avoirdupois (oz) & 28.35 & $\operatorname{gram}(\mathrm{g})$ \\
\hline
\end{tabular}

Temperature in degrees Celsius $\left({ }^{\circ} \mathrm{C}\right)$ may be converted to degrees Fahrenheit ( $\left.{ }^{\circ} \mathrm{F}\right)$ as follows:

${ }^{\circ} \mathrm{F}=\left(1.8 x^{\circ} \mathrm{C}\right)+32$

Temperature in degrees Fahrenheit $\left({ }^{\circ} \mathrm{F}\right)$ may be converted to degrees Celsius $\left({ }^{\circ} \mathrm{C}\right)$ as follows:

${ }^{\circ} \mathrm{C}=\left({ }^{\circ} \mathrm{F}-32\right) / 1.8$

Vertical coordinate information is referenced to mean sea level.

Horizontal coordinate information is referenced to the North American Datum of 1983 (NAD 83).

Altitude, as used in this report, refers to distance above the vertical datum.

Specific conductance is given in microsiemens per centimeter at 25 degrees Celsius $(\mu \mathrm{S} / \mathrm{cm}$ at $\left.25^{\circ} \mathrm{C}\right)$.

Concentrations of chemical constituents in water are given in milligrams per liter (mg/L). 


\title{
Effects of Surface-Water Diversion and Ground-Water Withdrawal on Streamflow and Habitat, Punaluu Stream, Oahu, Hawaii
}

\author{
By Delwyn S. Oki, Reuben H. Wolff, and Jeff A. Perreault
}

\section{Abstract}

The surface- and ground-water resources of the Punaluu area of northeast Oahu, Hawaii, have been and continue to be important for cultural, domestic, agricultural, recreational, and aesthetic purposes. Punaluu Stream flows perennially because rain falls frequently in the area and ground water discharges to the stream. Flow in Punaluu Stream is reduced by the direct diversion of water for off-stream uses and possibly from the withdrawal of ground water near the stream. Punaluu Ditch diverts water from Punaluu Stream near an altitude of 210 feet.

During the recent period 1995-2004, discharge in Punaluu Stream that was equaled or exceeded 50 percent of the time (median or $\mathrm{Q}_{50}$ discharge) and discharge that was equaled or exceeded 95 percent of the time $\left(\mathrm{Q}_{95}\right.$ discharge $)$ measured immediately upstream from the Punaluu Ditch diversion intake, respectively, were 18 and 13 cubic feet per second, whereas the $\mathrm{Q}_{50}$ and $\mathrm{Q}_{95}$ discharges measured immediately downstream from the diversion intake, respectively, were 7.0 and 1.3 cubic feet per second. Thus, near an altitude of 210 feet, diversion of surface water by the Punaluu Ditch caused the $\mathrm{Q}_{50}$ discharge in Punaluu Stream to be reduced to 39 percent of the natural $\mathrm{Q}_{50}$ discharge, and the $\mathrm{Q}_{05}$ discharge was reduced to 10 percent of the natural value. The relative effects of the Punaluu Ditch diversion on flow in Punaluu Stream decreased in a downstream direction, mainly because of the compensating effects of tributary inflows and ditch return flows. At an altitude of 10 feet, the $\mathrm{Q}_{50}$ discharge in Punaluu Stream was 82 percent of the natural $\mathrm{Q}_{50}$ discharge, and the $\mathrm{Q}_{95}$ discharge was 69 percent of the natural value.

Changes in streamflow affect the quantity and quality of physical habitat used by native stream fauna. The Physical Habitat Simulation System (PHABSIM) approach was used to evaluate the effects of different diversion scenarios on physical habitat for selected native species in Punaluu Stream. Habitat-suitability criteria developed for streams in northeast Maui, Hawaii, were used to determine the effects of incremental changes in streamflow on physical habitat, in terms of weighted usable area (WUA) in Punaluu Stream.

The effects of different diversion conditions on WUA for Neritina granosa and Awaous guamensis were evaluated by determining the average number of days per year for which WUA values are less than a specified reference value (during periods when discharge is less than or equal to the median natural discharge). For recent diverted conditions (19952004), the average number of days per year that WUA values are less than 50 or 75 percent of the WUA value at median natural discharge generally (1) decreases in a downstream direction, reflecting the effects of tributary inflows and ditch return flows, (2) is less than the corresponding number of days for constant diversion rates greater than about 4-5 cubic feet per second at a stream altitude of 10 feet, and (3) is greater than the corresponding number of days for a constant diversion rate of 10 cubic feet per second at stream altitudes of 40, 100, and 140 feet. The number of days that WUA values are less than 75 percent of the WUA value at median natural discharge generally increases substantially for constant diversion rates exceeding about $4-5$ cubic feet per second. At stream altitudes of 10, 40, 100, and 200 feet and for constant diversion rates of up to 4 cubic feet per second, WUA values are less than 75 percent of the WUA value at median natural discharge for fewer than 13 days per year. At stream altitudes above 40 feet and for a constant diversion rate of 10 cubic feet per second, WUA values are less than 75 percent of the WUA value at median natural discharge for 131 to 183 days per year.

Stream temperature is a factor that potentially could affect the abundance and distribution of native aquatic species. Measured stream temperatures immediately upstream and downstream from the diversion intake did not indicate a significant change in temperature caused by a reduction in flow. Measured daily maximum temperatures did not exceed $25^{\circ} \mathrm{C}$ and daily minimum temperatures did not drop below $17.5^{\circ} \mathrm{C}$ at any of the six sites between altitudes of 10 and 210 feet where temperatures were measured. At all six sites, daily maximum temperatures remained below the upper-lethal-temperature limits for native aquatic species.

On the basis of (1) measured water levels in wells, relative to stream-channel altitudes and (2) discharge measurements indicating where the stream commonly gains water, Punaluu Stream is likely connected to the main ground-water body below an altitude of about 25 feet. Measured water levels in monitoring wells in the volcanic rocks indicate that 
ground-water withdrawals west of Punaluu Stream cause ground-water-level declines east of the stream. Thus, water levels in the volcanic-rock aquifer beneath and adjacent to Punaluu Stream are affected by withdrawals from existing well fields. If a continuous zone of saturation exists between the stream and the underlying volcanic rocks, long-term waterlevel declines caused by withdrawals from existing wells in the volcanic rocks will ultimately extend to the stream and cause a reduction of ground-water discharge to the stream. The magnitude of streamflow reduction is unknown, but may be immeasurable, depending on the rate of withdrawal, because of the presence of low-permeability sedimentary deposits separating the stream and underlying volcanic rocks. The effects of ground-water withdrawal on streamflow may be best evaluated using a numerical ground-water model that accounts for the hydraulic characteristics of the rocks between sites of ground-water withdrawal and the stream.

\section{Introduction}

The surface- and ground-water resources of the Punaluu area of northeast Oahu, Hawaii, (fig. 1) have been and continue to be important for cultural, domestic, agricultural, recreational, and aesthetic purposes. Punaluu Stream provides water for traditional and customary Hawaiian practices, irrigation of agricultural crops and ornamental plants, livestock, and aquaculture operations. In addition, Punaluu Stream provides habitat for native aquatic species. The ground-water system near Punaluu Stream is hydraulically connected to the stream in some areas and is a source of drinking water.

Surface water historically was diverted from Punaluu Stream for taro and sugarcane cultivation (R.M. Towill Corporation, 1978; Dorrance and Morgan, 2000). In the Punaluu area, surface-water diversion systems for taro cultivation existed prior to the 1900s, and diversion systems for sugarcane cultivation were constructed in the early 1900s (Wilcox, 1996). Punaluu Ditch (fig. 2), which was constructed in the 1920s for sugarcane irrigation (Takasaki and others, 1969), continues to divert water from Punaluu Stream in 2005 for other uses. Punaluu Ditch consists of 12 tunnels connected by open ditches or flumes and extends $1.8 \mathrm{mi}$ from the intake at an altitude of about $210 \mathrm{ft}$ to its terminus in Kaluanui Stream Valley at an altitude of about $50 \mathrm{ft}$ (fig. 2). The tunnels range from about 50 to more than $800 \mathrm{ft}$ in length (John Primacio, Jr., Kamehameha Schools contractor, written commun., 2004). In recent years, a partial collapse within one of the tunnels (tunnel 11) has restricted flow within the ditch system to some users (The Honolulu Advertiser, June 13, 1993, p. A9). Currently (2005) water from Punaluu Ditch mainly is used for taro cultivation, vegetable crops, ornamental plants, livestock, and aquaculture operations. Punaluu Stream flows perennially, although diversion of water from the stream may result in periods of zero flow immediately downstream from the Punaluu Ditch intake.
The first reported well in the Punaluu area was drilled in 1925 and mainly was for domestic use. Since 1925, additional wells in the Punaluu area were drilled for domestic, agricultural, or municipal supply (fig. 3). Currently (2005), the main use of ground water in the area is for municipal purposes. During 2000-2002, reported ground-water withdrawal from the two main well fields in the Punaluu area averaged about 6.5 million gallons per day $(\mathrm{Mgal} / \mathrm{d})$, and was reduced to 2.4 Mgal/d during 2004 (unpub. digital data, Hawaii State Commission on Water Resource Management, 2005).

Flow in Punaluu Stream is reduced by the direct diversion of water for off-stream uses and possibly from the withdrawal of ground water near the stream. Reductions in streamflow may affect the quantity and quality of habitat for native species as well as stream temperatures. The State Water Code mandates that the Hawaii State Commission on Water Resource Management (CWRM) establish a statewide instream-use protection program (State Water Code, section 174C-71). The principal mechanism that CWRM has for the protection of instream uses is to establish instream flow standards. Beneficial instream uses recognized by CWRM include: (1) maintenance of fish and wildlife habitat, (2) outdoor recreational activities, (3) maintenance of ecosystems such as estuaries, wetlands, and stream vegetation in riparian areas, (4) aesthetic values such as waterfalls and scenic waterways, (5) maintenance of water quality, (6) the conveyance of irrigation and domestic water supplies to downstream points of diversion, and (7) the protection of traditional and customary Hawaiian rights. Scientific information generated by this study will help CWRM to fulfill its obligation to determine a technically defensible instream flow standard for Punaluu Stream.

\section{Objectives}

In cooperation with the City and County of Honolulu Board of Water Supply (BWS), the U.S. Geological Survey (USGS) undertook an investigation to evaluate the effects of surface-water diversion from Punaluu Stream on streamflow characteristics and habitat availability for native fauna. The objectives of this study were to: (1) assess the effects of the existing surface-water diversion on flow characteristics in Punaluu Stream, (2) estimate the effects of surface-water diversion on habitat availability for selected native stream fauna in Punaluu Stream, (3) characterize the effects of surface-water diversion on instream temperatures, and (4) assess the potential for existing ground-water withdrawals to affect streamflow.

\section{Purpose and Scope}

This report provides information necessary for establishing instream flow standards for Punaluu Stream. The purpose of this report is to assess effects of surface-water diversion and ground-water withdrawal on streamflow characteristics and habitat in Punaluu Stream, Oahu, Hawaii. Available discharge 

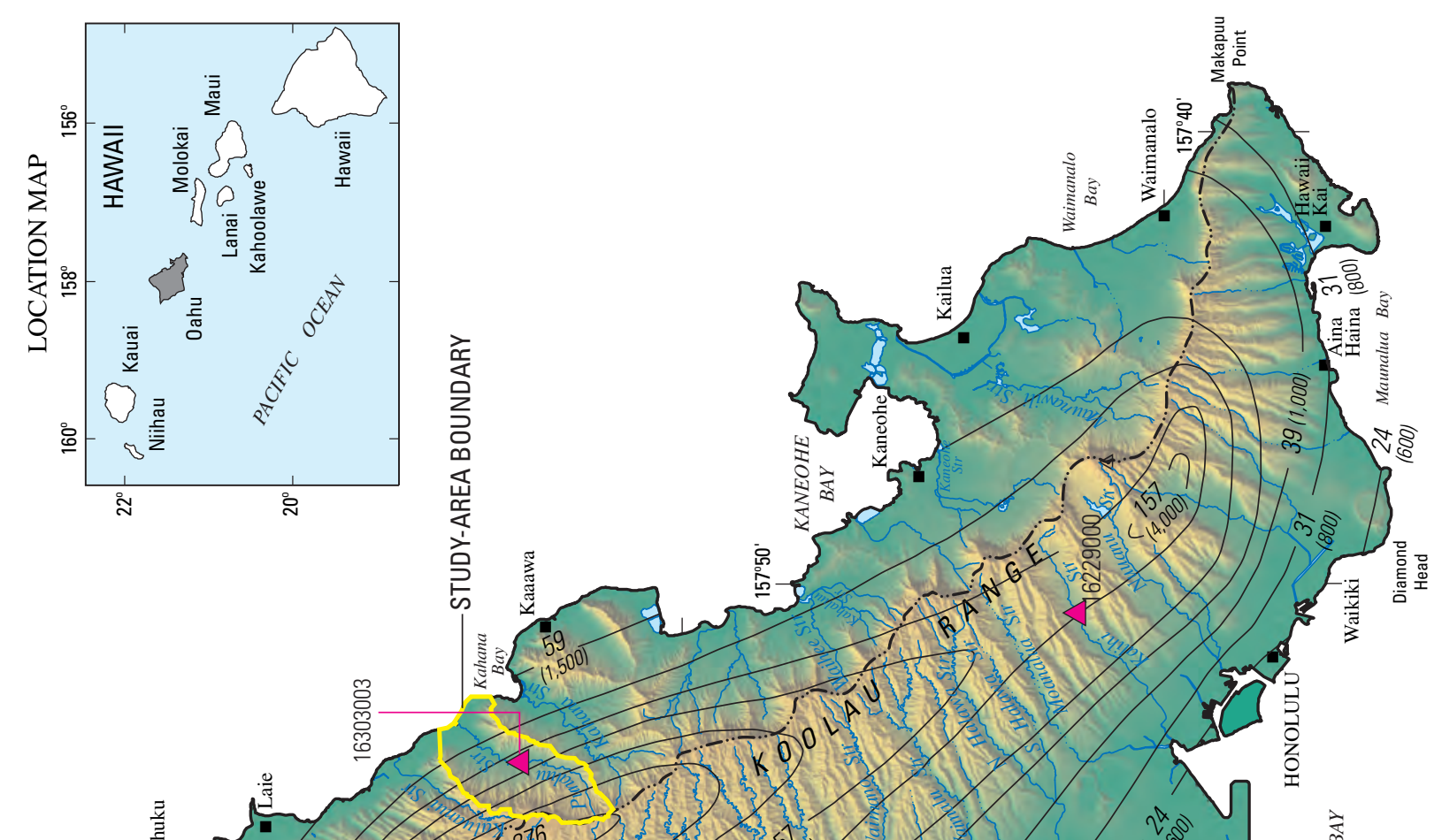

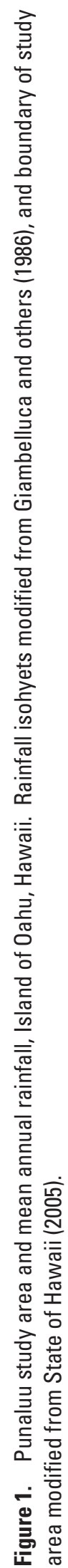




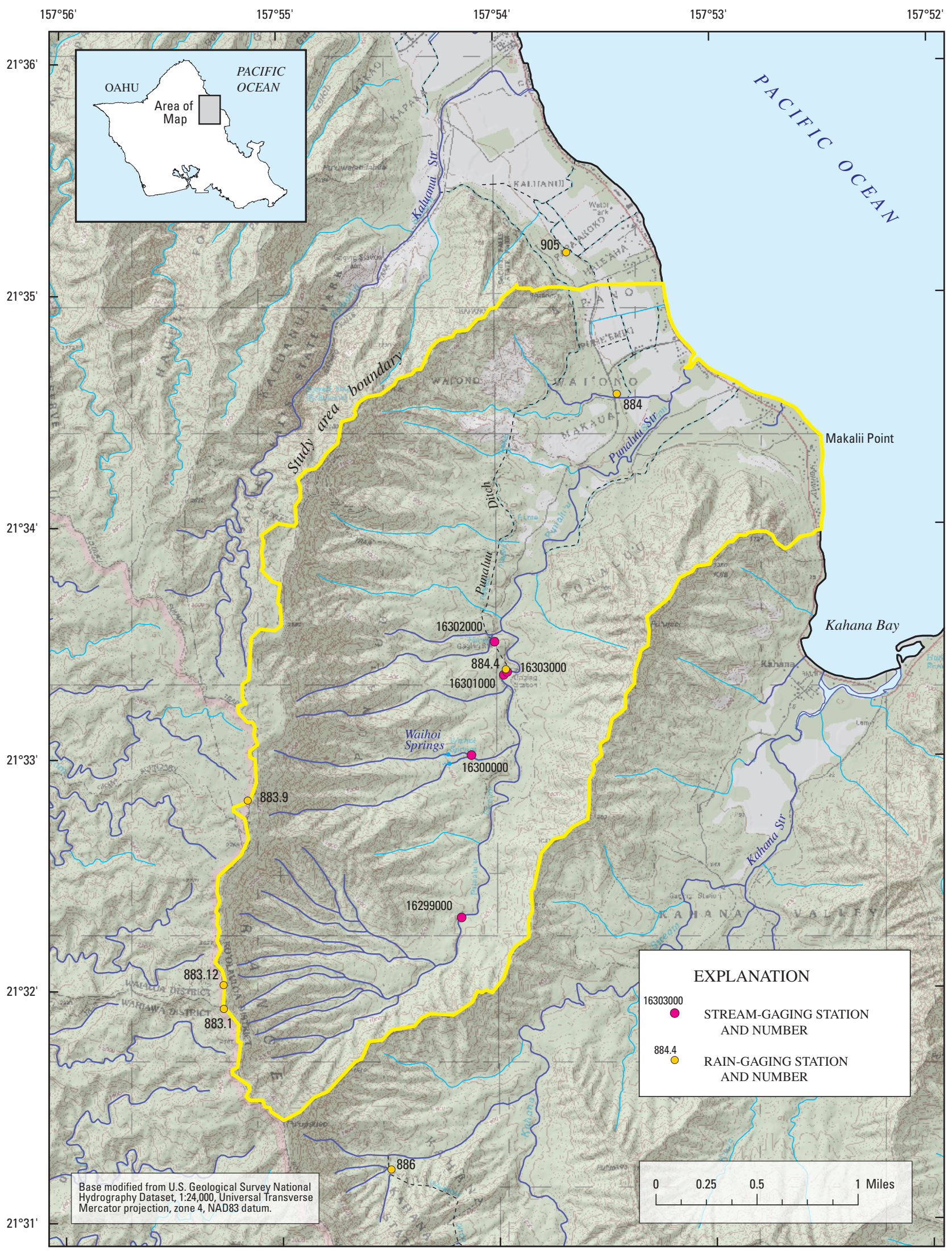

Figure 2. Topographic map of Punaluu study area and selected stream- and rain-gaging stations, Oahu, Hawaii. 


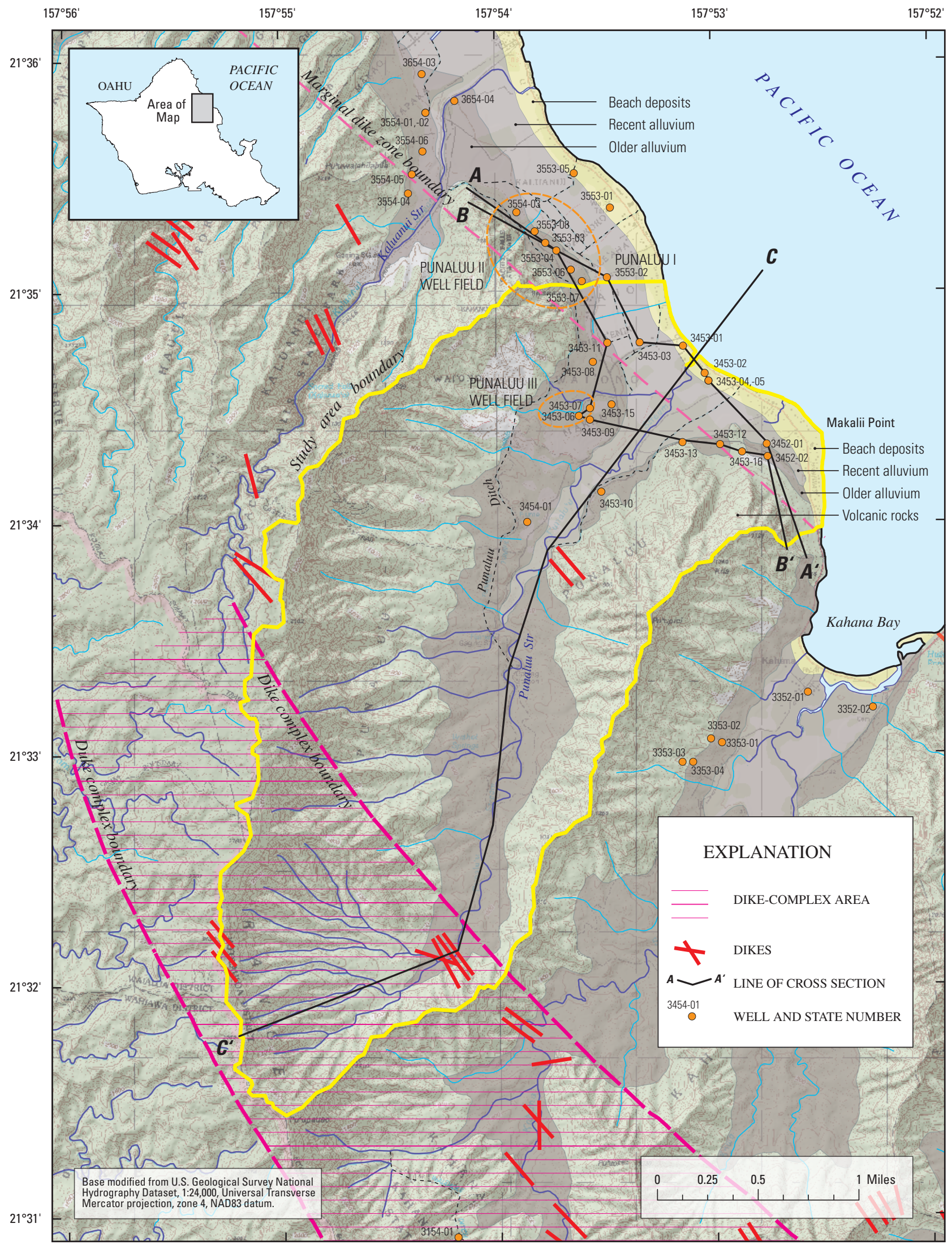

Figure 3. Geologic features and wells in the Punaluu area, Oahu, Hawaii. Modified from Stearns (1939) and Takasaki and Mink (1985). 
data from USGS stream-gaging stations at unregulated stream sites, historical seepage-run data, and additional discharge measurements made for this study are used to estimate undiverted streamflow characteristics and the effects of diversion on streamflow characteristics. Relations between streamflow and habitat for native stream macrofauna are used to estimate the effects of streamflow diversion on habitat for native stream macrofauna. This study is not designed to address the effects of flow diversion on native species abundance (which would require considerably more time and control over diversion rates than was available), water requirements for taro cultivation and aesthetic or recreational uses, algae and invertebrate food sources for native macrofauna, and reproduction and recruitment of native species. Information from ground-waterlevel monitoring and seepage runs will be used to evaluate the potential for ground-water withdrawals to affect streamflow.

\section{Acknowledgements}

The authors acknowledge the members of the Punaluu Watershed Alliance (Punaluu Community Association, Honolulu Board of Water Supply, Kamehameha Schools, and Hawaii State Commission on Water Resource Management) for their support throughout this study. Creighton and Cathleen Mattoon, G. Mahealani “Mahi” Trevenen, Kapua SproatFonoimoana, Samuel Rowland, and Katy Darlington were among the members of the Punaluu Community Association that shared their knowledge and provided historical perspectives of conditions in the Punaluu area. Kapua Sproat Fonoimoana also kindly allowed us to monitor water levels in a well on her property. Special thanks go out to John Primacio, Jr. ("Junior") and Darrel Tachibana (Kamehameha Schools contractors), who manage the Punaluu-Ditch system in Punaluu (among their many duties), for sharing their knowledge, enabling us to gain access to monitoring wells, and for always ensuring our safety while working in the area.

This study could not have been completed without the assistance of the following USGS personnel. Benjamin H. Shimizu and Heather A. Jeppesen expertly maintained USGS gaging stations in the Punaluu area, helped with seepage-run measurements, and kindly accommodated our use of field vehicles and equipment. Moani M.L. Hibbard helped establish the temperature-monitoring network for this study and she, along with Kenneth N. Natividad and Tracy J. Ibarra, spent many long days in Punaluu assisting with data-collection activities (collecting habitat information, making discharge measurements, measuring ground-water levels, and surveying). Leigh Marcello assisted with snorkeling surveys and collection of non-native fish species for gut-content analysis. Chiu W. Yeung, Chien-Hwa (Max) Chen, and Bret Hayhurst helped with seepage-run measurements. Todd K. Presley provided assistance installing temperature probes and shared his expertise on surveying stream cross sections. Richard A. Fontaine provided technical assistance and insightful comments throughout the study.

\section{Setting}

The study area $\left(6.7 \mathrm{mi}^{2}\right)$ is located in the wet, northeastern part of Oahu and is mainly defined by the drainage basin of Punaluu Stream (fig. 3). The study area is bounded by the ridge between Punaluu and Kahana Stream Valleys on the southeast, the topographic crest of the Koolau Range (the eroded remnant of the Koolau Volcano) on the southwest, the ridge between Punaluu and Kaluanui Stream Valleys on the northwest, and the coast on the northeast. Punaluu Stream originates near the topographic crest of the Koolau Range at an altitude of about 2,600 ft and terminates near sea level at the coast.

\section{Land Use}

Prior to 1900, the coastal plain within the Punaluu area, which is below an altitude of about $20 \mathrm{ft}$, was an extensive swampy area that was used for taro cultivation (Territorial Planning Board, 1939; Handy and others, 1991). In addition to flatland areas, hillsides in the Punaluu area also were terraced for taro (Handy and others, 1991). By 1937, most of the area previously used for taro cultivation was planted in sugarcane (Territorial Planning Board, 1939). Sugarcane was cultivated within about $1.2 \mathrm{mi}$ from the coast below altitudes of $200 \mathrm{ft}$. Sugarcane cultivation was the dominant agricultural land use in the Punaluu area from the early 1900s to 1971, when Kahuku Plantation Company ceased operations (Dorrance and Morgan, 2000). Land mainly was forested inland of sugarcane-cultivation areas, although some areas may have been used for grazing (Territorial Planning Board, 1939). Areas on the coastal plain adjacent to the existing highway are developed for residential use. Agricultural land uses in the Punaluu area during 1998 included banana and guava orchards; fruit, vegetable, and wetland row crops; and horticulture, aquaculture, and grazing (Klasner and Mikami, 2003).

\section{Climate}

Climate within the study area is characterized by mild temperatures and cool and persistent northeasterly winds, known locally in Hawaii as trade winds (Blumenstock and Price, 1967; Sanderson, 1993). In general, mild temperatures in Hawaii are attributed to the large heat capacity of the surrounding ocean. Near the coast in the Punaluu area, estimated mean annual air temperature is between about $73.5^{\circ} \mathrm{F}$ and $75^{\circ} \mathrm{F}$, and the estimated average lapse rate, or decline of temperature with altitude, is about $3.6^{\circ} \mathrm{F}$ per $1,000 \mathrm{ft}$ (Nullet and Sanderson, 1993).

Topography and the direction of the trade winds control rainfall in the study area. Moisture-laden northeasterly trade winds rise orographically along the windward slopes, and as the air mass rises and cools, moisture condenses and commonly precipitates on the mountain slopes. Mean annual rain- 
fall in the Punaluu area is about 280 in. near the mountainous interior and greater than 60 in. near the coast (fig. 1).

Within the study area, the pattern of seasonal rainfall differs between coastal areas and interior areas. Near the coast, a pronounced rainy season occurs during October through April and a dry season occurs during May through September (fig. 4). Near the mountainous interior areas, rainfall is less variable, although rainfall generally is lowest during the months of June and September (fig. 4).

During storms, rainfall totals in the study area may be significant. Estimated 2-yr, 24-hour rainfall ranges from about 6 in. near the coast to more than 9 in. near interior areas; estimated 100-yr, 24-hour rainfall ranges from about 15 in. near the coast to more than 20 in. near interior areas (Giambelluca and others, 1984).

\section{Geologic Setting}

Punaluu Stream Valley is wider and more deeply eroded than stream valleys farther north, which are in a more recent stage of dissection. Erosion of Punaluu Stream Valley likely was enhanced by high rainfall on the northeastern side of
Oahu. Within the study area, the geologic setting mainly consists of volcanic rocks overlain by sedimentary deposits that form the valley floor at altitudes below about $650 \mathrm{ft}$ above mean sea level (fig. 3) (Stearns, 1939). The volcanic rocks are composed of shield-stage lavas from the Koolau Volcano, which forms the eastern part of Oahu. A coastal plain formed by sedimentary deposits is about one-half mile wide near the mouth of Punaluu Stream. The coastal plain is continuous to the north, although it is truncated to the south by a volcanic ridge that extends to the coast between Punaluu and Kahana Stream Valleys. The geologic setting of Punaluu Stream Valley controls the occurrence of and interaction between surface water and ground water in the area. In some places, the presence of low-permeability rocks that impede ground-water flow may create high ground-water levels and result in discharge of ground water to Punaluu Stream and perennial streamflow.

\section{Volcanic Rocks}

Exposed volcanic rocks within Punaluu Stream Valley are classified as Koolau Basalt, consisting of shield-stage tholeiitic basalt (Langenheim and Clague, 1987). Potassium-

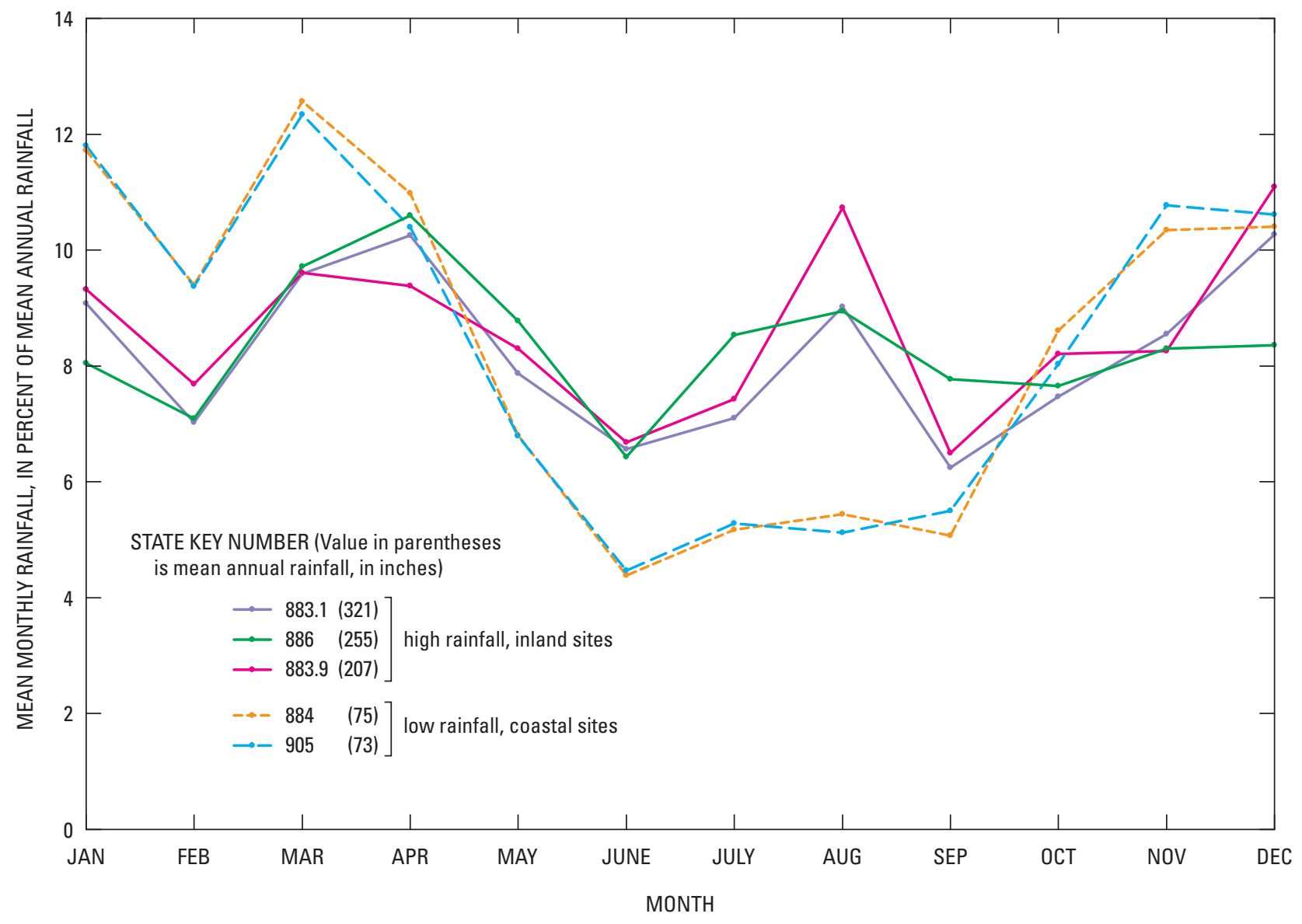

Figure 4. Mean monthly rainfall at selected rain-gaging stations near Punaluu, Oahu, Hawaii (data are 1916-1983 adjusted mean values from Giambelluca and others, 1986). 
argon determinations of Koolau Basalt indicate an age of 1.8 to 2.6 million years (Doell and Dalrymple, 1973). Lava flows from the shield-stage Koolau Basalt typically are thin-bedded, with an average flow thickness of about $10 \mathrm{ft}$, and have dips of 3 to 10 degrees (Stearns and Vaksvik, 1935). Within the study area, lava flows have been intruded by dikes, which are thin, near-vertical sheets of massive rock that are created by intrusion of magma. In the central part of a rift zone, known as the dike complex, dikes may number as many as 1,000 per mile of horizontal distance and compose 10 percent or more of the total rock volume (Takasaki and Mink, 1985). The number of dikes decreases toward the outer edges of a rift zone. At the outer part of the rift zone, within the marginal dike zone, dikes usually constitute less than 5 percent of the total rock volume (Takasaki and Mink, 1985). Takasaki and Mink (1985) indicate that the dike complex in Punaluu Stream Valley exists above a stream altitude of about $560 \mathrm{ft}$, and the marginal dike zone between stream altitudes of about 10 and $560 \mathrm{ft}$ (fig. 3). The dike complex and marginal dike zone defined by Takasaki and Mink (1985) are generalized and approximate. Dikes commonly are exposed by erosion within rift zones of volcanoes, although few dikes have been mapped in the study area because of the steep terrain and dense vegetation cover (Takasaki and others, 1969). In Punaluu Stream Valley, dikes have been mapped near stream altitudes of about 70 and $620 \mathrm{ft}$ (fig. 3) (Takasaki and others, 1969; Takasaki and Mink, 1985).

Permeability describes the ease with which fluid can move through rock. The permeability of volcanic rocks is variable and depends on many factors including the mode of emplacement and amount of weathering. Weathered volcanic rocks generally have a much lower permeability than unweathered volcanic rocks. Lava chemistry and topography also can affect permeability. In the Punaluu area, dike-free volcanic rocks are much more permeable than intrusive dikes and older sedimentary deposits, and are limited to the coastal area seaward of the marginal dike zone.

Within the rift zone, intrusive dikes reduce overall permeability of the volcanic rocks and impede flow of ground water. Although the thickness of individual dikes generally is less than $10 \mathrm{ft}$, dikes are hydrologically significant because of their impounding effect on ground water. In general, the overall permeability of a rift zone decreases as the number of dike intrusions within the rift zone increases. Thus, the overall permeability of the dike-complex area is expected to be lower than that of the marginal dike zone.

The effects of dikes on ground-water flow in the Punaluu area were indicated in an aquifer test in which well 3553-03 was pumped at a rate of about 2,100 gallons per minute ( $\mathrm{gal} / \mathrm{min}$ ) and water levels were monitored in well 3553-01 located about 2,100 ft from the pumped well (fig. 3). The relation between water-level drawdown (arithmetic scale) and time (logarithmic scale) shows increases in slope that commonly are associated with dike barriers (fig. 5). Williams and Soroos (1973) estimated the distance between well 3553-01 and the nearest dike barrier to be between about 6,850 and $8,950 \mathrm{ft}$, although the location of the barrier could not be determined.

\section{Sedimentary Deposits}

Within Punaluu Stream Valley, the sedimentary deposits generally are thickest near the coast and thinnest near steeper inland areas. In the central part of the valley near the coast, sedimentary deposits are greater than $200 \mathrm{ft}$ thick (fig. 6) and consist of recent marine and terrestrial material underlain by older alluvium. In inland areas, the sedimentary deposits consist mainly of alluvium and colluvium.

Older alluvium consists of terrestrial sediments, varying in size from fine-grain particles to boulders, which have been weathered and compacted into a soft coherent mass, and is exposed at various places in the stream channel. Older alluvium forms deposits in Punaluu Stream Valley and beneath the coastal plain and is hydrologically significant because of its low permeability. The low permeability of older alluvium is caused by a reduction of pore space from the volume increase associated with weathering as well as mechanical compaction (Wentworth, 1951). Sedimentary deposits and underlying weathered volcanic rocks of the coastal plain form a low-permeability confining unit (caprock) that overlies higher-permeability volcanic rocks and impedes the seaward discharge of freshwater from the volcanic-rock aquifer. Weathered volcanic rocks probably extend below the sedimentary deposits that fill Punaluu Stream Valley, although the depth to which weathering extends is poorly known.

In the Honolulu area of southern Oahu, valley-filling sedimentary deposits and underlying weathered volcanic rocks extend hundreds of feet below sea level, form barriers to ground-water flow, and cause distinct water-level differences on opposite sides of the valley (see for example Palmer, 1946). The effects of valley-filling deposits and underlying weathered volcanic rocks in the Punaluu area are poorly known, but data collected for this study and described later (see section "Effects of Ground-Water Withdrawal on Streamflow") provide insight into the hydrologic effectiveness of the valley-filling deposits.

\section{Surface-Water Resources}

Punaluu Stream is a perennial stream that receives flow from numerous tributaries, many of which also are perennial. Punaluu Stream flows perennially because rain falls frequently in the area and ground water discharges to the stream. Punaluu Stream flows perennially during periods of no rainfall because of ground-water discharge to the stream (base flow). During water years 1955-2004, the lowest daily mean discharge recorded in Punaluu Stream just upstream from the Punaluu Ditch intake was $8.0 \mathrm{ft}^{3} / \mathrm{s}$ on October 5, 1968. The Punaluu Ditch and tunnel system was constructed in the 1920s (Takasaki and others, 1969) to divert water from the stream for irrigation of sugarcane fields at lower altitudes. Although sugarcane is no longer cultivated on Oahu, Punaluu Ditch continues to be maintained and operated by the current land owner, Kamehameha Schools. 


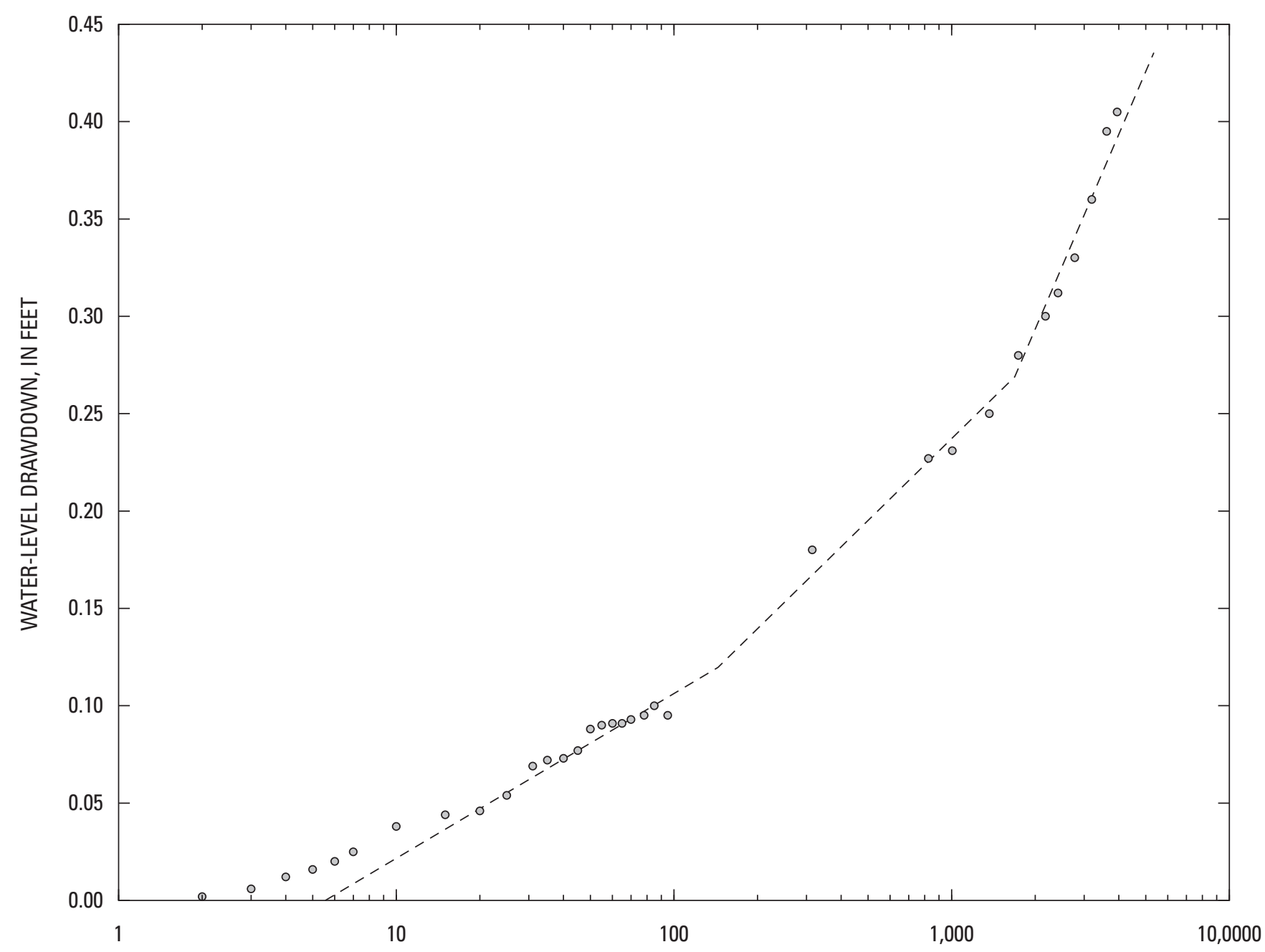

TIME SINCE START OF PUMPING, IN MINUTES

Figure 5. Water-level drawdown in well 3553-01 caused by withdrawal from well 3553-03 at a rate of 2,100 gallons per minute, Punaluu, Oahu, Hawaii. Wells 3553-01 and 3553-03 are about 2,100 feet apart. Modified from Williams and Soroos (1973).

\section{Punaluu Stream}

Streamflow consists of (1) direct runoff of rainfall, in the forms of overland flow and interflow, (2) ground-water discharge to the stream (base flow), (3) water returned from bank storage, (4) rain that falls directly on the stream, and (5) any additional water, including excess irrigation water, discharged to the stream by humans (Oki, 2003). The amount of direct runoff and base flow that contributes to total streamflow is dependent on factors including rainfall amount and intensity, drainage-basin attributes (geology, morphology, and size), soils, and land cover. Evapotranspiration from riparian vegetation potentially can result in loss of ground water that otherwise may have discharged to the stream. Streamflow charac- teristics also can be affected by humans through diversions, channel modifications, land-use changes, and other factors.

Direct runoff occurs during and immediately following a period of rainfall and may be produced by several processes. Direct runoff may contribute to streamflow for several days following a period of rainfall. When the capacity of soil to accept water and the capacity of land-surface depressions to store water are exceeded, water begins to run off in a sheet as overland flow. Rain that falls on saturated soils, where the ground-water table is at the land surface or rises to the land surface during a storm, runs off as saturation overland flow. During a storm, overland flow may be generated over only parts of a basin.

Rainfall that infiltrates the ground surface may move laterally in near-surface soils and rocks and contribute to 
$\boldsymbol{A}$

$\boldsymbol{A}^{\prime}$
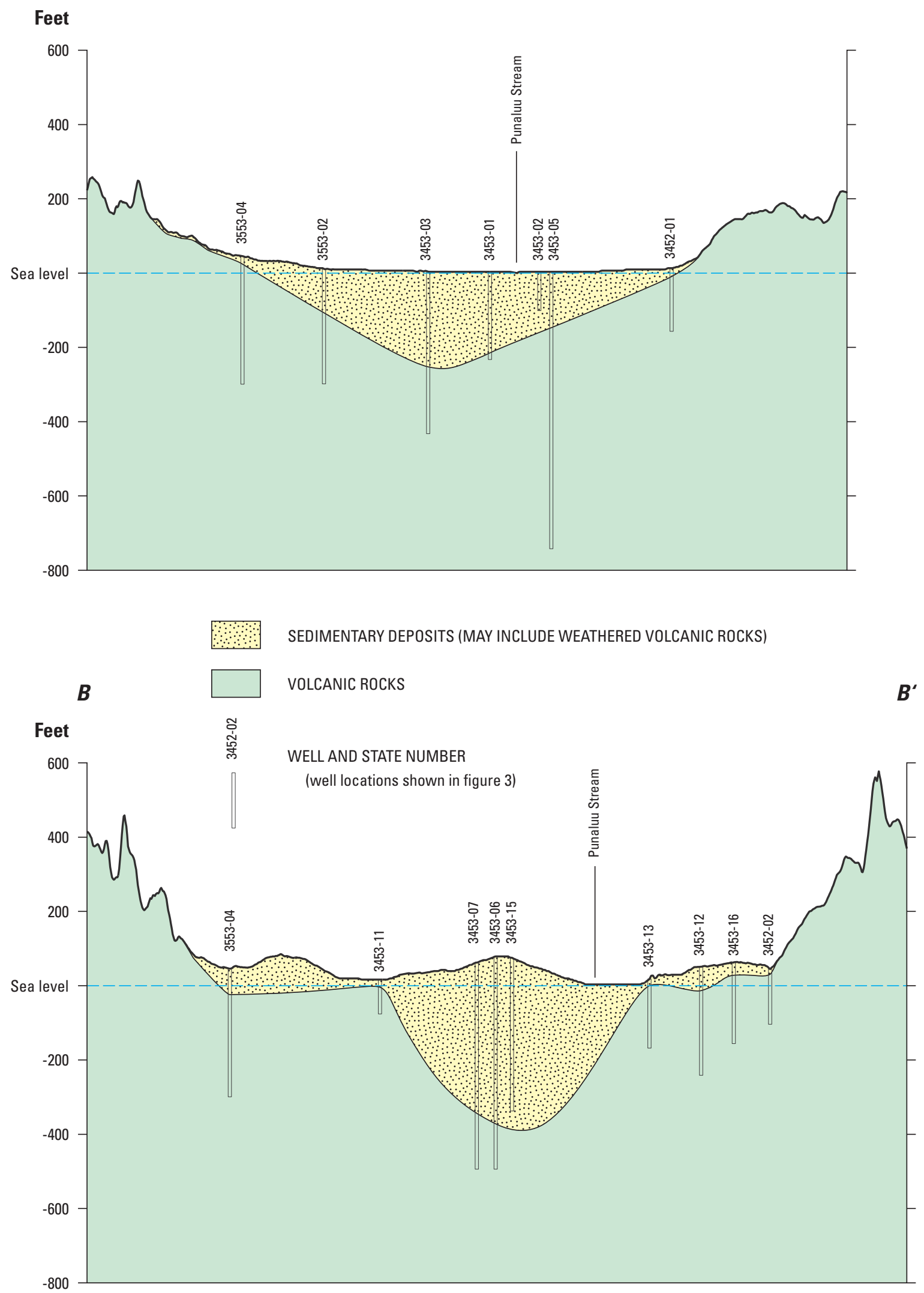

Figure 6. Geologic cross sections, Punaluu, Oahu, Hawaii. Section locations shown in figure 3. 
streamflow as interflow (also known as subsurface runoff, subsurface storm flow, or storm seepage). A significant amount of interflow may occur during and following a storm where permeable surface soils and rocks overlie less permeable soil or rock layers. Water movement associated with interflow generally is slower than that associated with overland flow, and may continue for days following a period of rainfall. In some places, interflow may move quickly to streams through preferential pathways.

Rainfall that infiltrates the ground surface also may recharge a ground-water body that discharges to a stream. Such ground-water discharge, known as base flow, originates where streams intersect the ground-water table and where the water level in the adjacent ground-water body is above the water level in the stream. Base flow may occur during extended dry periods as well as during periods of rainfall. Because ground-water levels vary with time, base flow also varies with time; base flow is high during periods when the ground-water level is high, relative to the water level in the stream; low during periods when the ground-water level is low; and may cease if the ground-water level falls below the water level in the stream. Variations in base flow, however, are much smaller than variations in direct runoff.

During a period of heavy rainfall, stream stage (water level) rises and water is absorbed into the banks of the stream as bank storage. This water may return to the stream and contribute to streamflow when the stream stage recedes.

Prior to 1953, the flow characteristics of Punaluu Stream could be determined only from a limited number of discharge measurements (Martin and Pierce, 1913; Kunesh, 1929) and short-term records at a few stream-gaging stations (Martin and Pierce 1913; Fontaine, 1996). The USGS maintained gaging stations on Punaluu Stream at an altitude of $539 \mathrm{ft}$ (station 16299000) during 1915-1918, and at an altitude of $250 \mathrm{ft}$ (station 16301000) during 1914-1918 (fig. 2). Data from these two gaging stations indicate perennial flow. During water years 1916-1917, complete data were available at both gaging stations 16299000 and 16301000 . Flow-duration curves based on these data (fig. 7) indicate that median daily discharges in Punaluu Stream at altitudes of 539 and $250 \mathrm{ft}$, respectively, were 6.5 and $25 \mathrm{ft}^{3} / \mathrm{s}$.

During 1915-1917, the USGS also maintained a gaging station on Waihoi Stream (station 16300000), which is a tributary to Punaluu Stream, although only weekly staff-gage readings were made after November 9, 1915 (Grover and Larrison, 1917). Minimum observed discharge in Waihoi Stream during the 1915-1917 period of record generally was between about 4 and $7 \mathrm{ft}^{3} / \mathrm{s}$.

Since 1953, the USGS has maintained two continuous-record gaging stations in the Punaluu study area, one on Punaluu Stream at an altitude of about $210 \mathrm{ft}$ (station 16303000) and the other on Punaluu Ditch (station 16302000) about $900 \mathrm{ft}$ from the intake on Punaluu Stream (fig. 2). Records indicate that flow in Punaluu Ditch for water year 1954 may have been affected by unmeasured flow through a wasteway gate (Takasaki and others, 1969). Gaging sta- tion 16303000 on Punaluu Stream measures the discharge downstream from the diversion intake, whereas gaging station 16302000 measures the discharge that is diverted from the stream. Thus, the combined discharge measured by gaging stations 16302000 and 16303000 represents the total flow in Punaluu Stream before water is diverted. The combined discharge from stations 16302000 and 16303000 is assigned to station 16303003. During water years 1955-2004, mean discharges measured at gaging stations 16303000 and 16303003 , respectively, were 16.4 and $24.9 \mathrm{ft}^{3} / \mathrm{s}$. Minimum daily mean discharges measured at gaging stations 16303000 and 16303003 , respectively, were 0.0 and $8.0 \mathrm{ft}^{3} / \mathrm{s}$, whereas maximum daily mean discharges, respectively, were 1,010 and 1,020 ft $\mathrm{ft}^{3} / \mathrm{s}$. During 1955-2004, daily mean discharge at gaging station 16303000 was zero on about 0.5 percent of the days.

Streamflow variability is inversely related to the time scale used to characterize flow. That is, streamflow variability increases as the time scale used to characterize flow decreases. During water years 1955-2004, annual mean discharges in Punaluu Stream at station 16303003 ranged from $14.3 \mathrm{ft}^{3} / \mathrm{s}$ in 1984 to $39.3 \mathrm{ft}^{3} / \mathrm{s}$ in 1965 (fig. 8). Daily mean discharges at station 16303003 are more variable, ranging from $8.0 \mathrm{ft}^{3} / \mathrm{s}$ (October 5, 1968) to $1,020 \mathrm{ft}^{3} / \mathrm{s}$ (April 15, 1963) during the same 50 -yr period.

During water years 1955-2004, mean monthly discharge in Punaluu Stream (station 16303003) was highest during April $\left(29.6 \mathrm{ft}^{3} / \mathrm{s}\right)$ toward the end of the wet season and lowest during September $\left(20.2 \mathrm{ft}^{3} / \mathrm{s}\right)$ toward the end of the dry season (fig. 9). The pattern of mean monthly streamflow generally is consistent with the pattern of mean monthly rainfall measured by rain gages near the wetter, mountainous interior parts of the Punaluu area (fig. 4).

A flow-duration curve for daily mean discharges is a cumulative-frequency curve that shows the percentage of days specified discharges were equaled or exceeded during a given time period (fig. 10). Although a flow-duration curve does not account for the actual sequence of flows being characterized, it does provide insight into the availability and variability of flows at a site. The median, or $\mathrm{Q}_{50}$, discharge during a specified period is the discharge that is equaled or exceeded 50 percent of the time. Similarly, the $\mathrm{Q}_{95}$ discharge during a specified period is the discharge that is equaled or exceeded 95 percent of the time and, therefore, represents a lower discharge than the $\mathrm{Q}_{50}$ discharge. The flow-duration curve (based on daily mean discharges) for station 16303003 for water years 1955-2004 indicates that the long-term median discharge was $20 \mathrm{ft}^{3} / \mathrm{s}$ and the $\mathrm{Q}_{95}$ discharge was $11 \mathrm{ft}^{3} / \mathrm{s}$ (fig. 10).

\section{Base-Flow Characteristics}

For this study, the base-flow component of daily streamflow in Punaluu Stream was estimated using a computerized base-flow separation model (Wahl and Wahl, 1995). Two parameters, $\mathrm{f}$ (turning-point test factor) and $\mathrm{N}$ (number of days in window), are assigned in the model. A value of 0.9 was 


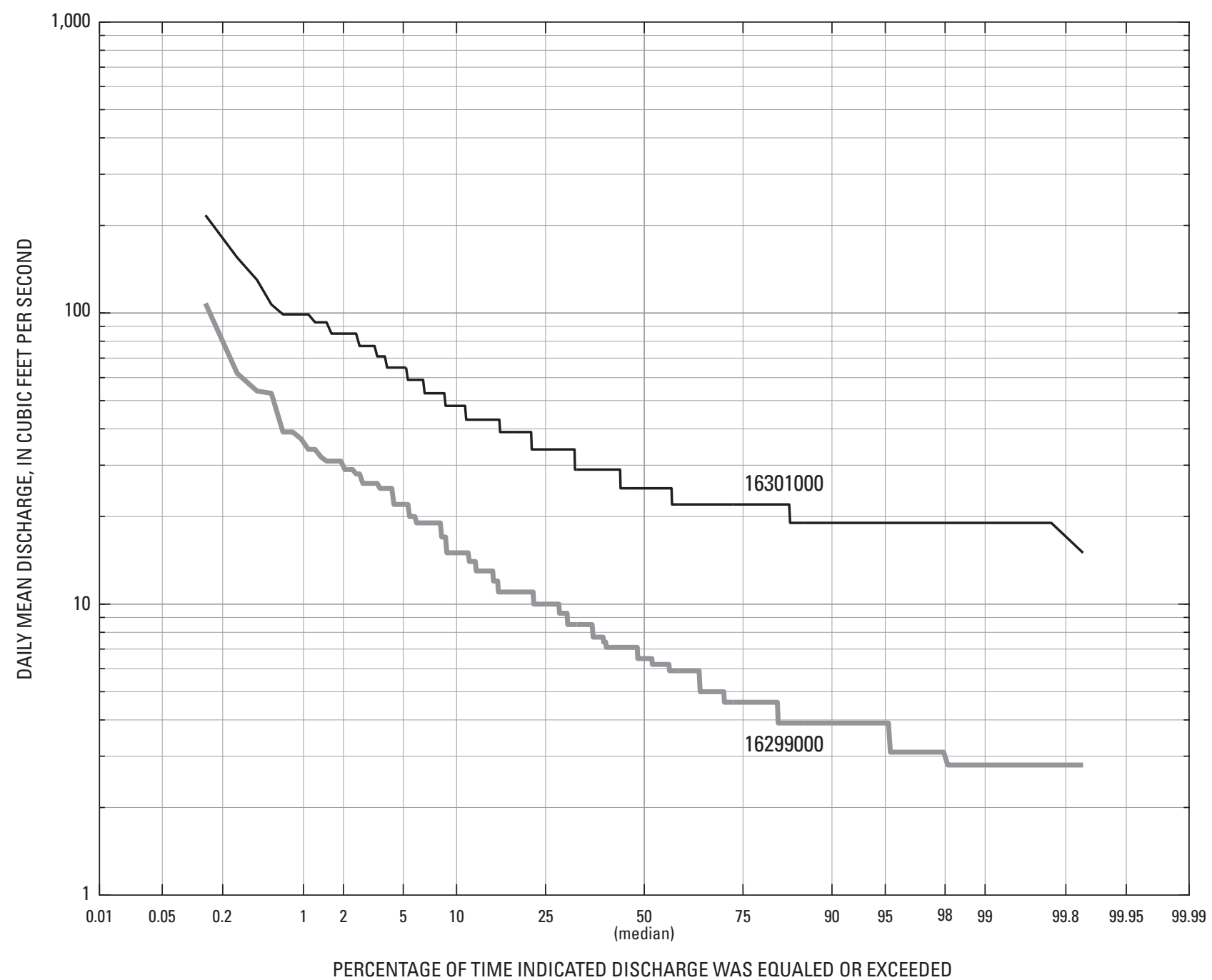

Figure 7. Flow-duration curves for Punaluu Stream (gaging stations 16299000 and 16301000) for water years 1916 and 1917, Oahu, Hawaii.

used for the turning-point test factor, $\mathrm{f}$. The model divides the daily streamflow record into non-overlapping $\mathrm{N}$-day periods and determines the minimum flow within each $\mathrm{N}$-day window. If the minimum flow within a given $\mathrm{N}$-day window is less than $\mathrm{f}(0.9)$ times the adjacent minimums, then the central window becomes a turning point on the base-flow hydrograph. The length of the $\mathrm{N}$-day window for a stream is an indicator of the time over which direct runoff occurs following a storm. For Punaluu Stream, $\mathrm{N}$ was assigned a value of 4 days.

For water years 1955-2004, the flow-duration curve for base flow in Punaluu Stream at station 16303003 is nearly the same as the flow-duration curve for total flow at flows less than the median (fig. 10). This indicates that flow in Punaluu Stream is dominated by ground-water discharge about 50 percent of the time. At flows higher than the median, the total and base-flow curves show greater separation (fig. 10). Dur- ing water years 1955-2004, mean base flow was $18.2 \mathrm{ft}^{3} / \mathrm{s}$, compared to mean total flow of $24.9 \mathrm{ft}^{3} / \mathrm{s}$. Thus, during water years 1955-2004, estimated base flow was 73 percent of the total flow in Punaluu Stream, and the remaining 27 percent of total flow was direct runoff. During water years 1955-2004, median base flow was $17.7 \mathrm{ft}^{3} / \mathrm{s}$ (fig. 10). The mean and median base-flow values correspond, respectively, to $\mathrm{Q}_{56}$ and $\mathrm{Q}_{63}$ values on the total streamflow flow-duration curve.

The steepness of a flow-duration curve provides an indication of flow variability. Steep flow-duration curves indicate high flow variability. The flow-duration curve for base flow at station 16303003 is flatter and indicates much less flow variability than the curve for direct runoff (difference between total streamflow and base flow) (fig. 10). Flow-duration curves that are relatively flat for flow-duration percentiles greater than 50 percent (flows less than median discharge) 

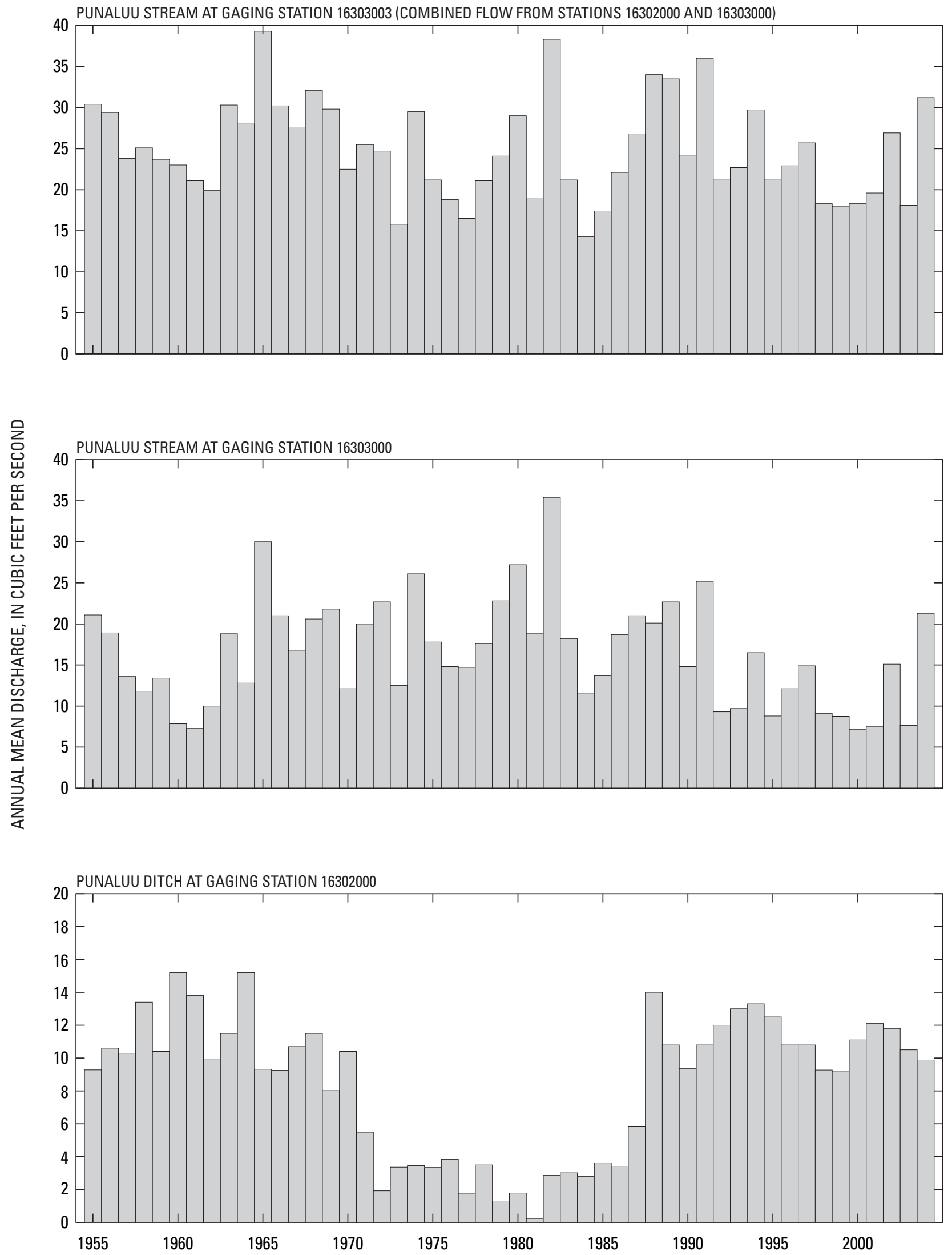

Figure 8. Annual mean discharge in Punaluu Stream (gaging stations 16303003 and 16303000) and Punaluu Ditch (gaging station 16302000), Oahu, Hawaii. 
PUNALUU STREAM AT GAGING STATION 16303003 (COMBINED FLOW FROM STATIONS 16302000 AND 16303000)
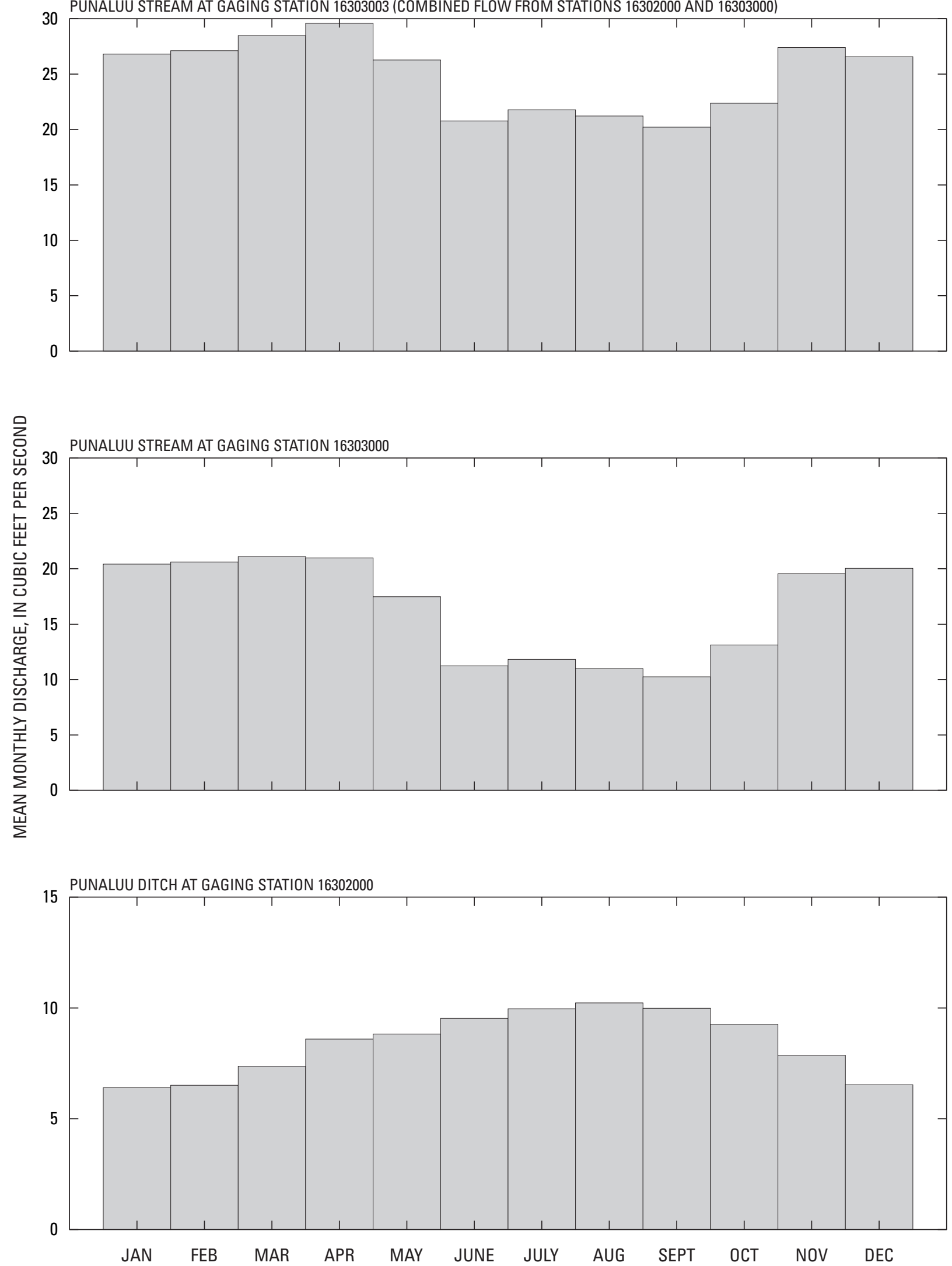

Figure 9. Mean monthly discharge in Punaluu Stream (gaging stations 16303003 and 16303000) and Punaluu Ditch (gaging station 16302000) during water years 1955-2004, Oahu, Hawaii. 


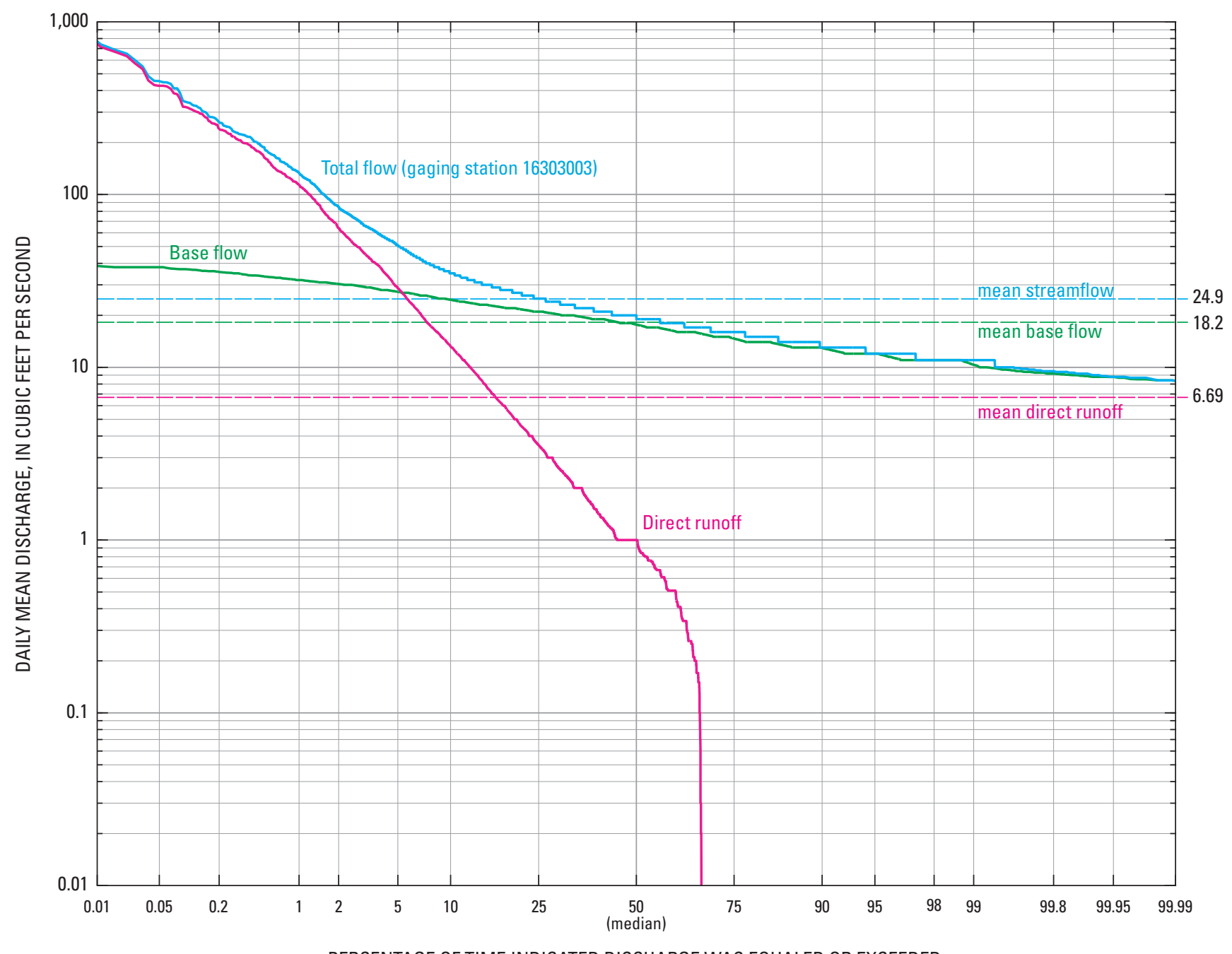

PERCENTAGE OF TIME INDICATED DISCHARGE WAS EQUALED OR EXCEEDED

Figure 10. Flow-duration curves for Punaluu Stream total flow, base flow, and direct runoff (gaging station 16303003), water years 1955-2004, Oahu, Hawaii.

indicate low variability for low-flow conditions. The ratio of $\mathrm{Q}_{95}$ to $\mathrm{Q}_{50}$ is an indicator of low-flow variability; a $\mathrm{Q}_{95}$-to- $\mathrm{Q}_{50}$ ratio that is close to 1 indicates low variability, which is indicative of a stream that receives steady ground-water discharge, whereas a ratio that is close to zero indicates high variability. During water years 1955-2004, the ratio of $Q_{95}$ to $Q_{50}$ for total streamflow at station 16303003 was 0.6 , which is indicative of low variability.

\section{Peak-Flow Characteristics}

Hawaiian streams are extremely flashy in nature because rainfall is commonly intense, drainage basins are small, basins and streams are steep, and channel storage is limited. A stream's stage can rise several feet in less than an hour during periods of intense rainfall, and discharge can increase by over an order of magnitude (fig. 11). High flows or floods are com- monly characterized by their magnitude and recurrence interval on the basis of the largest instantaneous peak discharge for each year of record (annual instantaneous peak flow). The recurrence interval is the expected (average) time between occurrences of annual instantaneous peak flows that exceed a given value. The recurrence interval, in years, is equal to the inverse of the exceedance probability for annual instantaneous peak flows. Thus, a flood with a 100 -yr recurrence interval (100-yr flood) has an annual exceedance probability of 0.01 (1 percent). Because a 1 -percent chance exists for a 100yr flood in any given year, it is possible that more than one 100 -yr flood may occur during a given 100 -yr period or even during a single year. On the basis of data from water years 1954-2004, the estimated 100-yr flood for Punaluu Stream at gaging station 16303000 is about $6,640 \mathrm{ft}^{3} / \mathrm{s}$ (fig. 12). The 100 -yr flood farther downstream is expected to be volumetrically larger because the drainage-basin area and total rainfall volume increase downstream. 


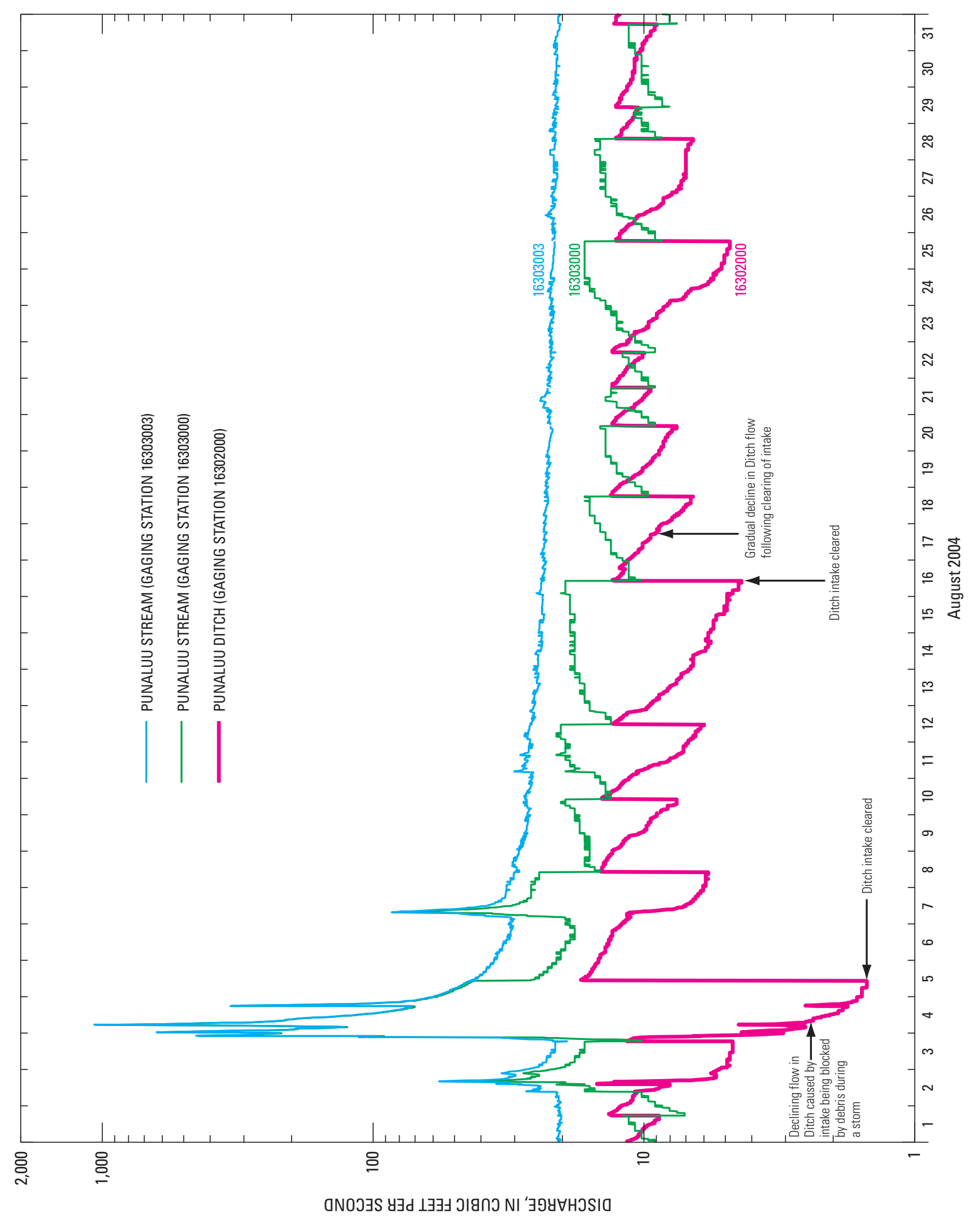

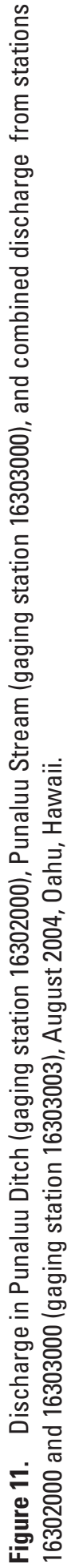

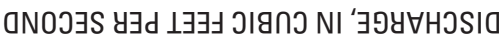




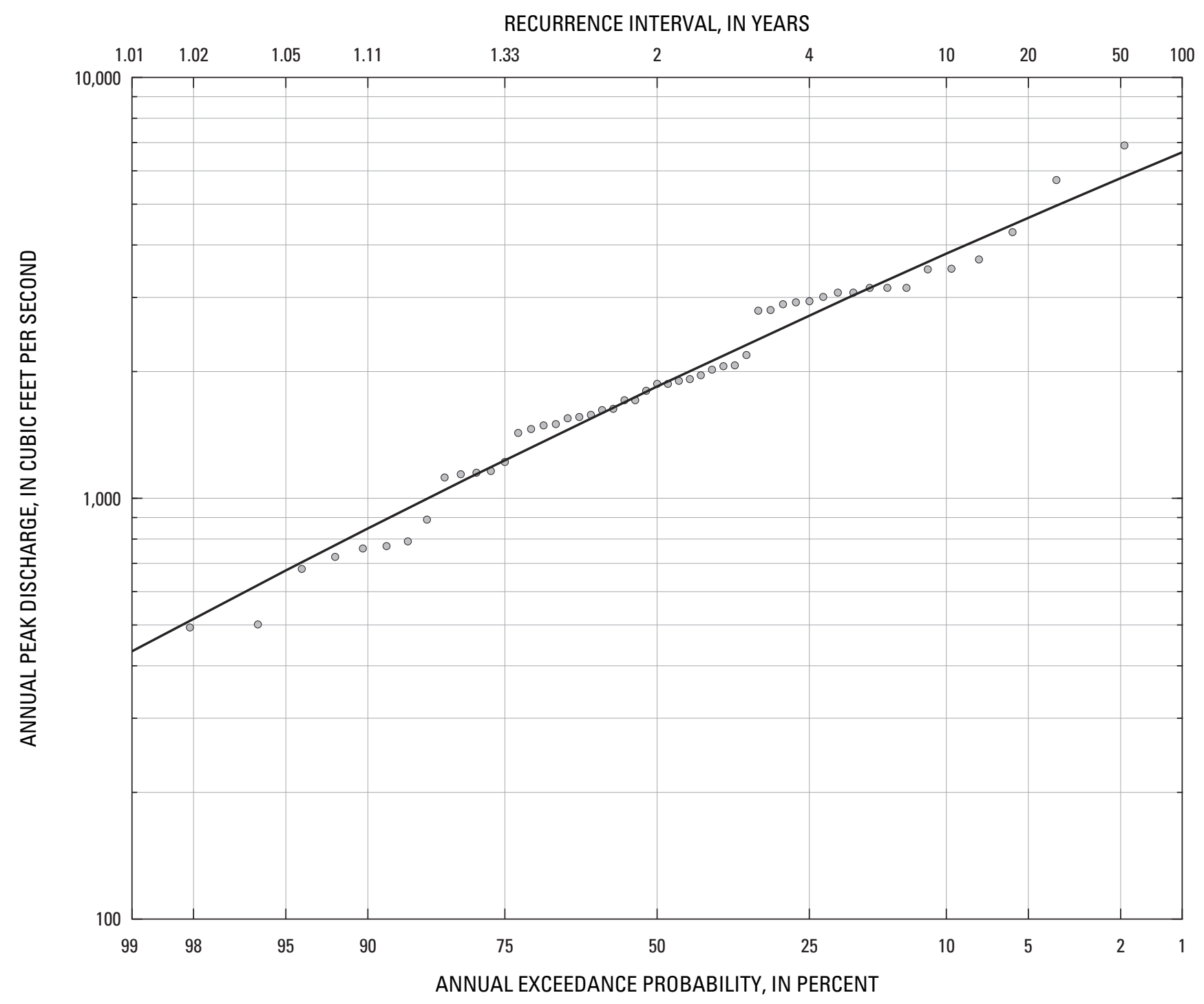

Figure 12. Probability of peak discharge being equaled or exceeded during any given year at Punaluu Stream (gaging station 16303000), Oahu, Hawaii. Annual exceedance probabilities determined from data during water years 1954-2004.

\section{Interaction Between Ground Water and Surface Water}

The rate and direction of water movement between streams and ground-water bodies depends on local geohydrologic conditions. Where the streambed is above the water table, the stream can lose water. Where the stream intersects the ground-water table, the stream can either gain or lose water, depending on whether the water level in the adjacent ground-water body is, respectively, greater than or less than the water level in the stream. Hydraulic properties of rocks near the stream affect the rate of flow between the stream and ground-water body.
Rainfall, ground-water withdrawals, and ocean tides, are factors that affect water levels in streams and ground-water bodies and the interaction between surface water and ground water. Prolonged periods of rainfall lead to increased groundwater recharge over a region and a rise in ground-water levels. Rising ground-water levels may lead to increased groundwater discharge to streams or reduced surface-water discharge to the ground-water body. Irrigation return flow, like rainfall, may contribute to increased ground-water recharge and affect the interaction between surface water and ground water. Ground-water withdrawals from wells cause a decline in ground-water levels that may extend to nearby streams. Where the stream and ground-water body are hydraulically connected, ground-water withdrawals may reduce groundwater discharge to streams (mainly base flow) or induce flow 
from the stream to the aquifer. The possible effects of groundwater withdrawal on flow in Punaluu Stream are discussed in a later section ("Effects of Ground-Water Withdrawal on Streamflow") of this report. At low altitudes, where water levels in streams and ground-water bodies are affected by ocean tides, streams may either gain or lose water during the day, depending on the relative effects of the ocean tide on streams and ground-water levels.

The upper reaches of Punaluu Stream are within or near the area where volcanic dikes impound ground water to high levels. The upper reaches of Punaluu Stream are perennial because the stream intersects the water table of the dike-impounded ground-water body and gains water from that ground-water body. (A description of the ground-waterflow system in the Punaluu area is provided in the "GroundWater-Flow System" section of this report.) Punaluu Stream flows perennially downstream from where dikes have been mapped because (1) tributaries that may originate near the dike-impounded ground-water body contribute to flow, (2) the stream may gain water from local ground water in the alluvium, and (3) permeability of the streambed is low enough to prevent major losses, thereby allowing water to flow continuously to the coast.

In general, flow in Punaluu Stream increases in a downstream direction, although localized decreases in flow are caused by diversions or infiltration to the underlying sediments. Discharge measurements (Kunesh, 1929; Takasaki and others, 1969) indicate that flow in Punaluu Stream increases between altitudes of about $650 \mathrm{ft}$ and $210 \mathrm{ft}$ (fig. 13). Flow in Punaluu Stream decreases near an altitude of $210 \mathrm{ft}$ because water is diverted from the stream by the Punaluu Ditch at that altitude (fig. 13). Above an altitude of $210 \mathrm{ft}$, downstream increases in flow in Punaluu Stream either are from ground water that discharges directly to the main stream or from tributaries that may receive ground-water discharge.

\section{Gains and Losses Below an Altitude of 210 Feet}

For this study, same-day discharge measurements (fig. 14; tables 1-2) were made along selected reaches of Punaluu Stream to determine the magnitude of streamflow gains and losses. These same-day measurements form what is commonly called a seepage run and are described in detail in the following section "Seepage Runs and Additional Discharge Measurements." Seepage-run measurements were made on days when flow generally was stable and direct runoff was considered to be negligible. Because of frequent rainfall within the drainage basin of Punaluu Stream, particularly near the mountainous interior areas, scheduling seepage-run measurements for periods of zero antecedent rainfall was not possible. Thus, the seepage-run measurements may be affected by unquantifiable, but likely small, amounts of direct runoff.

On the basis of the seepage-run measurements, Punaluu Stream (1) generally gains water between altitudes of 210 and $140 \mathrm{ft}$; (2) either gains or loses water, within about a $1-\mathrm{ft}^{3} / \mathrm{s}$ range, between altitudes of 140 and $60 \mathrm{ft}$; (3) may lose a few tenths of a cubic foot per second between altitudes of 60 and $40 \mathrm{ft}$; (4) generally loses water (as much as $0.5 \mathrm{ft}^{3} / \mathrm{s}$ ) between altitudes of 40 and $30 \mathrm{ft}$; (5) generally gains water (several tenths of a cubic foot per second) between altitudes of 30 and $10 \mathrm{ft}$; and (6) generally gains water (as much as $1 \mathrm{ft}^{3} / \mathrm{s}$ ) between altitudes of 10 and $5 \mathrm{ft}$. The general gain of water in Punaluu Stream below an altitude of $30 \mathrm{ft}$ is consistent with the head, as measured by water level, in the underlying ground-water body. (The hydraulic head at a point in an aquifer can be measured by the water level in a well, or piezometer, that is open to the aquifer only at that point.) Water-level measurements in wells in the area generally are between 5 and $25 \mathrm{ft}$ above mean sea level. Thus, it is plausible that ground water is discharging to Punaluu Stream below a stream-channel altitude of about $25 \mathrm{ft}$. Below an altitude of $25 \mathrm{ft}$, some of the flow increase in Punaluu Stream may be from irrigationreturn water and leakage from nearby aquaculture ponds that flow in the subsurface within the sedimentary deposits toward the stream. The variability of gains and losses (not associated with tributary inflows) within some stream reaches may reflect the transient nature of the interaction between the shallow ground water in the sedimentary deposits and flow in Punaluu Stream.

\section{Seepage Runs and Additional Discharge Measurements}

Seepage-run measurements on different reaches of Punaluu Stream below an altitude of $210 \mathrm{ft}$ were made on September 10, 2004; September 24, 2004; October 1, 2004; June 9, 2005; and August 5, 2005. During the 72-hr periods prior to the seepage runs, recorded rainfall at rain-gaging station 883.12 (Poamoho rain gage no. 1 near Wahiawa, Oahu) (fig. 2) varied from 0.19 to $2.07 \mathrm{in}$. During the 24 -hr periods prior to the seepage runs, recorded rainfall at rain-gaging station 883.12 varied from zero to 0.57 in. On the basis of recorded rainfall at rain-gaging station 883.12 (table 3), the seepage runs of September 24 and October 1, 2004 are the most likely to have been affected by direct runoff. Interpretation of the seepage run from October 1, 2004 is further confounded by the variable diversion of flow into Punaluu Ditch during the day. Thus, the measurements from October 1, 2004 are not used to interpret the distribution of flow in Punaluu Stream.

In general, flow in Punaluu Stream below an altitude of $210 \mathrm{ft}$ increases in a downstream direction, although flow in some reaches remains nearly constant or decreases slightly (fig. 15). Flow in Punaluu Stream increases because of inflow from tributaries, return flows from Punaluu Ditch, or discharge of ground water to the stream. The general increase of flow in a downstream direction also is indicated by discharge measurements taken during 1960-1962 (Takasaki and others, 1969) (fig. 15), although hydrologic conditions on the days of those measurements are not entirely known.

To better estimate the magnitude of gains from groundwater bodies and losses to infiltration in the main Punaluu 


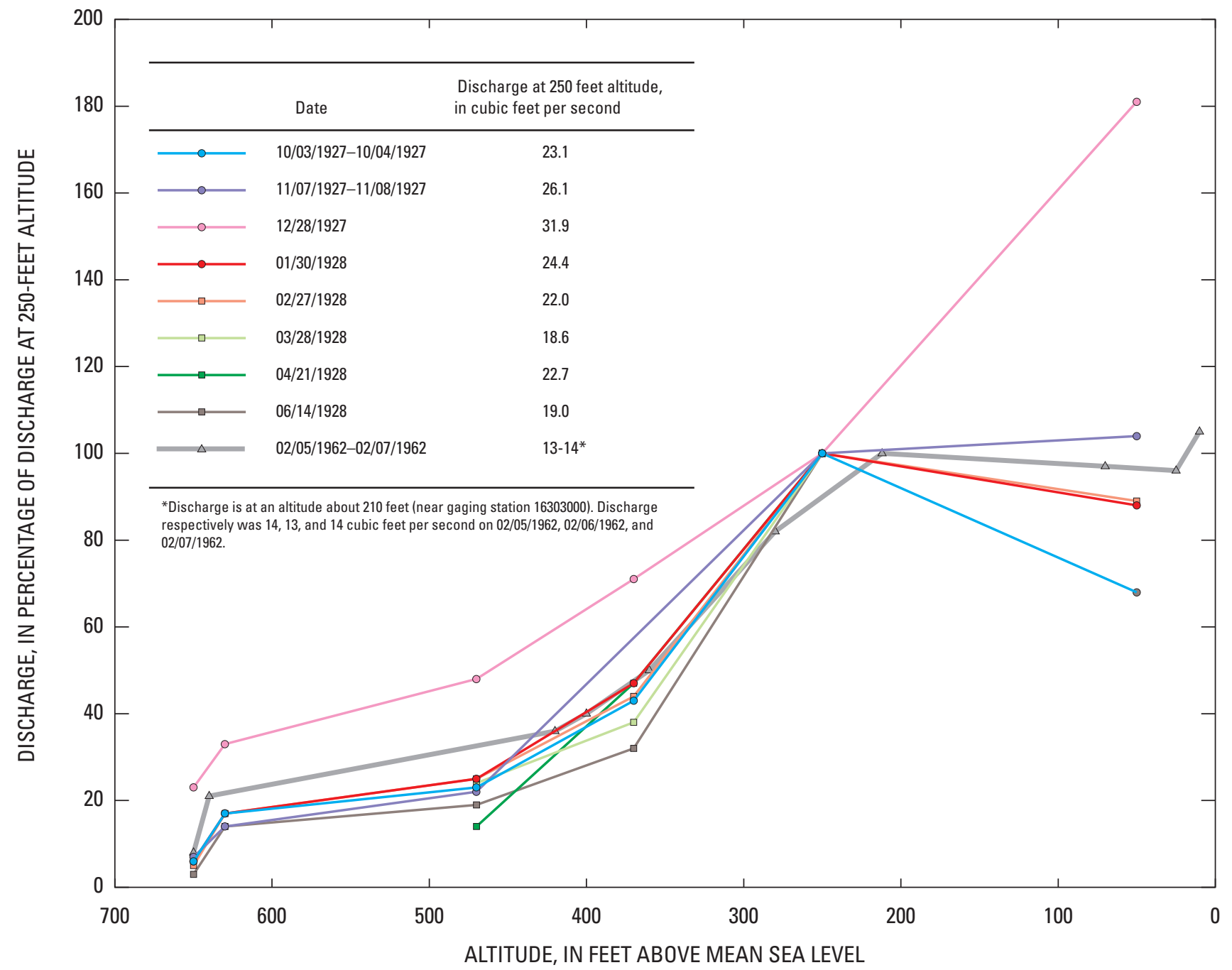

Figure 13. Discharge at selected altitudes, Punaluu Stream, Oahu, Hawaii. Data are from Kunesh (1929) and Takasaki and others (1969).

Table 3. Rainfall during the 24- and 72-hour periods prior to 8:00 a.m. on the days of seepage-run measurements, Punaluu Stream, Oahu, Hawaii.

\begin{tabular}{|c|c|c|c|c|c|}
\hline & \multicolumn{5}{|c|}{ Rainfall, in inches } \\
\hline & 09/10/2004 & 09/24/2004 & $10 / 01 / 2004$ & 06/09/2005 & 08/04/2005 \\
\hline & \multicolumn{5}{|c|}{ Rain-gaging station 883.12} \\
\hline 24-hour antecedent period & 0.38 & 0.57 & 0.38 & 0.00 & 0.00 \\
\hline \multirow[t]{2}{*}{ 72-hour antecedent period } & 0.75 & 1.69 & 2.07 & 0.57 & 0.19 \\
\hline & \multicolumn{5}{|c|}{ Rain-gaging station 884.4} \\
\hline 24-hour antecedent period & 0.3 & 0.1 & 0.0 & 0.0 & 0.0 \\
\hline 72-hour antecedent period & 0.4 & 0.2 & 0.1 & 0.6 & 0.1 \\
\hline
\end{tabular}




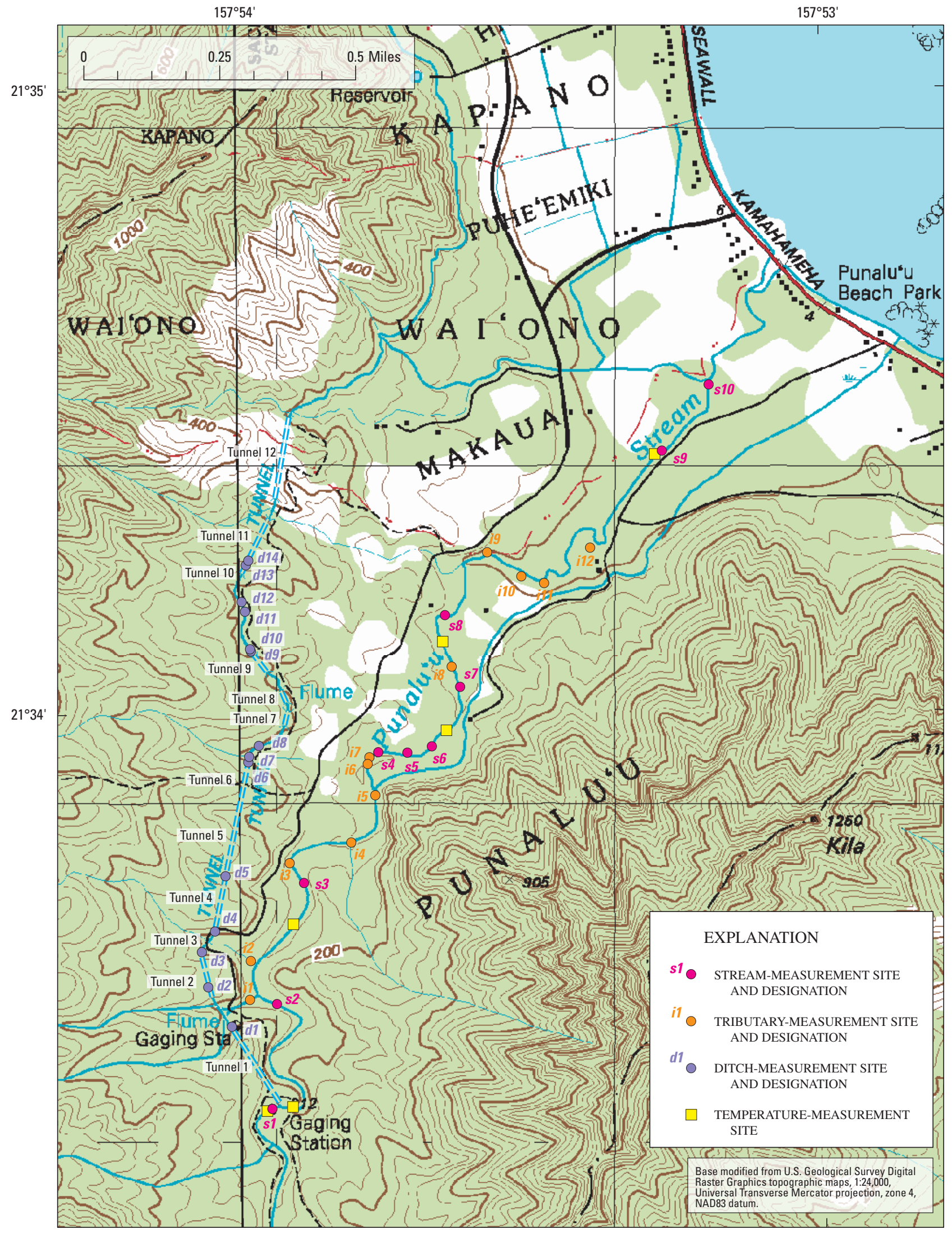

Figure 14. Sites of discharge measurements on Punaluu Stream and tributaries and Punaluu Ditch, Oahu, Hawaii, 2004 and 2005. 

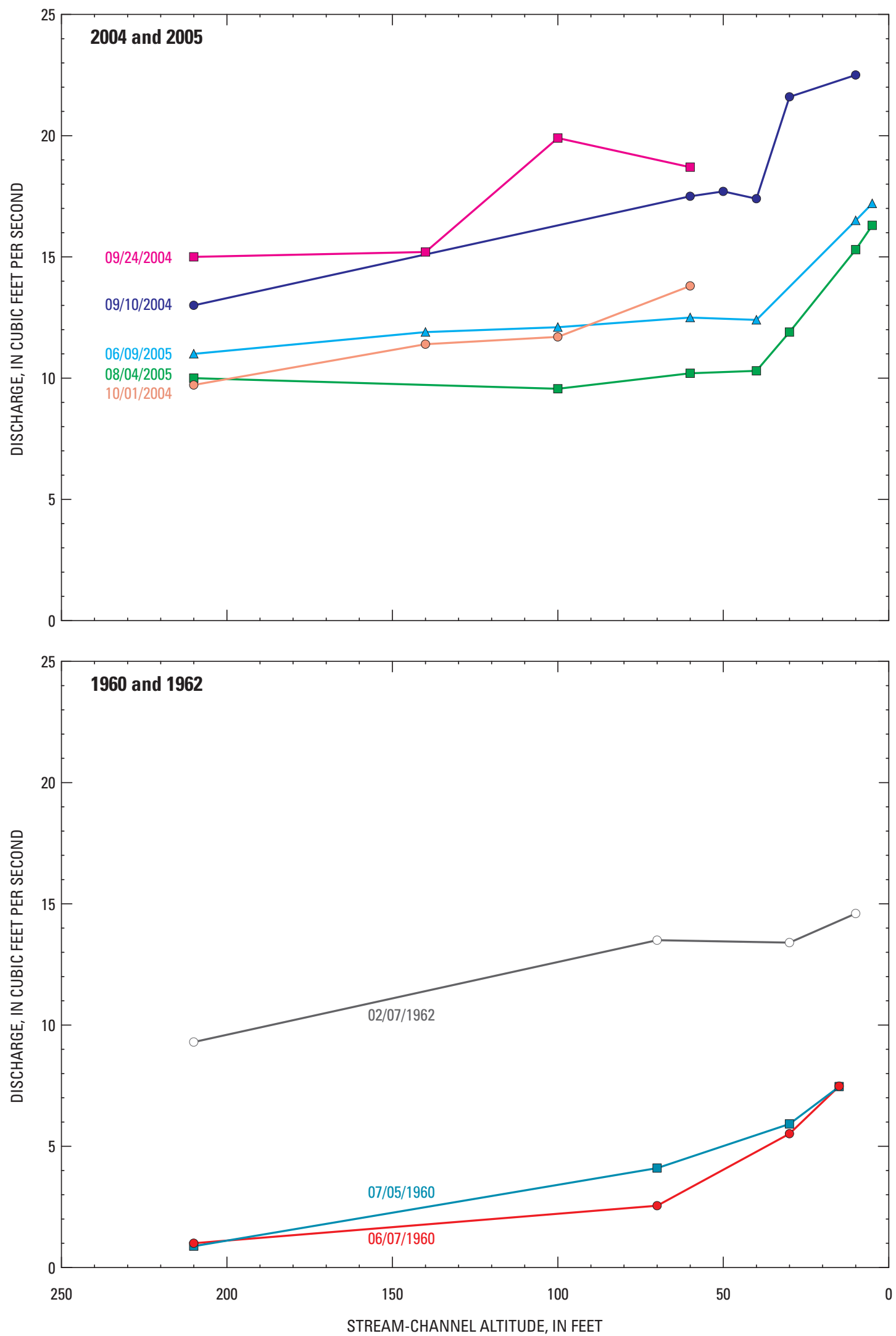

Figure 15. Streamflow variation with stream-channel altitude below 210 feet, Punaluu Stream, Oahu, Hawaii. Stream discharge measurements may include upstream inflows from tributaries or ditch return flows. 
Stream channel, tributary inflows and ditch-return flows were subtracted from all measured streamflow values downstream from the inflows (fig. 16). Thus, for a discharge of $10 \mathrm{ft}^{3} / \mathrm{s}$ at hypothetical upstream site A, a discharge of $11 \mathrm{ft}^{3} / \mathrm{s}$ at hypothetical downstream site $\mathrm{B}$, and a tributary inflow of $1 \mathrm{ft}^{3} / \mathrm{s}$ between sites $A$ and $B$, the $1 \mathrm{ft}^{3} / \mathrm{s}$ inflow was subtracted from the $11 \mathrm{ft}^{3} / \mathrm{s}$ discharge at site B. This would result in discharges of $10 \mathrm{ft}^{3} / \mathrm{s}$ at both sites $\mathrm{A}$ and $\mathrm{B}$, which would indicate no net gain or loss of water in the main stream channel between the sites.

Results of seepage runs (and additional same-day discharge measurements made at multiple sites), after excluding tributary inflows and ditch-return flows between streammeasurement sites, indicate variable gains and losses in some reaches of Punaluu Stream below an altitude of $210 \mathrm{ft}$ (fig. 16). This variability may reflect real differences in gains and losses along a reach from day to day or the accuracy with which discharge measurements could be made.

Between stream-channel altitudes of $210 \mathrm{ft}$ (gaging station 16303000) and $140 \mathrm{ft}$, Punaluu Stream commonly gains water. On the basis of seven discharge measurements at an altitude of $140 \mathrm{ft}$ and the corresponding discharges from the gaging station at $210 \mathrm{ft}$ (16303000) during the 3 -hr periods (representative of concurrent flow conditions) prior to the start of the measurements, Punaluu Stream gained from 0.2 to $1.5 \mathrm{ft}^{3} / \mathrm{s}$. (Measurements on November 2, 2004, March 3, 2005, and May 25, 2005 were not considered in the analysis because of changing flow conditions at the gaging station.) The average difference in discharge between altitudes of 210 and $140 \mathrm{ft}$ is a gain of $0.8 \mathrm{ft}^{3} / \mathrm{s}$. Because possible tributary inflows between the sites were not measured, gains in the main stream channel may be slightly overestimated. However, tributary inflows between altitudes of 210 and $140 \mathrm{ft}$ typically are small or zero during low-flow conditions.

Between stream-channel altitudes of 140 and $100 \mathrm{ft}$, Punaluu Stream may gain or lose water, depending on prevailing local conditions. Flows in Punaluu Stream at altitudes of 140 and $100 \mathrm{ft}$ and two left-bank (viewed in a downstream direction) tributary inflows between these altitudes were measured on 7 different days in 2004 and 2005. However, on 2 days (October 1, 2004, and May 25, 2005), comparisons of flows along Punaluu Stream are questionable because of changing flow conditions in the stream, as indicated by data from gaging station (16303000). On November 2, 2004, discharge measurements indicate that Punaluu Stream gained $1.5 \mathrm{ft}^{3} / \mathrm{s}$ between altitudes of 140 and $100 \mathrm{ft}$, although the measurements were made during a recession period that may have been affected by interflow. Between altitudes of 140 and 100 $\mathrm{ft}$, Punaluu Stream lost $1.0 \mathrm{ft}^{3} / \mathrm{s}$ on June 9, 2005, and gained 3.2, 0.5, and $0.2 \mathrm{ft}^{3} / \mathrm{s}$, respectively, on September 24, 2004 , March 22, 2005, and April 14, 2005. The $3.2 \mathrm{ft}^{3} / \mathrm{s}$ gain on September 24, 2004, may reflect an overestimate of flow at an altitude of $100 \mathrm{ft}$ because of possible measurement errors associated with using a vertical-axis current meter in that setting.

Between stream-channel altitudes of 100 and $60 \mathrm{ft}$, Punaluu Stream may gain or lose water, depending on prevail- ing local conditions. Flows in Punaluu Stream at altitudes of 100 and $60 \mathrm{ft}$ were measured during four seepage runs, although measurements on October 1, 2004 are not considered in this analysis. Punaluu Stream lost $1.9 \mathrm{ft}^{3} / \mathrm{s}$ on September 24, 2004, flow remained constant on June 9, 2005, and Punaluu Stream gained $0.4 \mathrm{ft}^{3} / \mathrm{s}$ on August 4, 2005. The $1.9 \mathrm{ft}^{3} / \mathrm{s}$ loss on September 24, 2004 may reflect an overestimate of flow at an altitude of $100 \mathrm{ft}$ because of possible measurement errors associated with using a vertical-axis current meter in that setting. Between altitudes of 140 and $60 \mathrm{ft}$, Punaluu Stream gained $1.3 \mathrm{ft}^{3} / \mathrm{s}$ on September 24, 2004 and lost $1.0 \mathrm{ft}^{3} / \mathrm{s}$ on June 9, 2005.

Between stream-channel altitudes of 60 and $40 \mathrm{ft}$, Punaluu Stream may lose up to a few tenths of a cubic foot per second. On September 10, 2004, measured flows in Punaluu Stream at altitudes of 60 and $40 \mathrm{ft}$, respectively, were 17.5 and $17.4 \mathrm{ft}^{3} / \mathrm{s}$. About $0.2 \mathrm{ft}^{3} / \mathrm{s}$ discharge, possibly from nearby aquaculture ponds, entered the stream between altitudes of 60 and $55 \mathrm{ft}$ and, thus, Punaluu Stream lost about $0.3 \mathrm{ft}^{3} / \mathrm{s}(=17.4$ $-0.2-17.5$ ) between altitudes of 60 and $40 \mathrm{ft}$. On August 4, 2005, available discharge measurements indicate that Punaluu Stream lost at least $0.14 \mathrm{ft}^{3} / \mathrm{s}$ between altitudes of 60 and $40 \mathrm{ft}$.

Between stream-channel altitudes of 40 and $30 \mathrm{ft}$, Punaluu Stream commonly loses water (as much as $0.5 \mathrm{ft}^{3} / \mathrm{s}$ ). Flows in Punaluu Stream at altitudes of 40 and $30 \mathrm{ft}$ and ditch-return flows between these altitudes were measured on 4 different days in 2004 and 2005. Return flow (typically between 1 and $6 \mathrm{ft}^{3} / \mathrm{s}$ ) from Punaluu Ditch enters Punaluu Stream from the left bank of the stream near an altitude of about $35 \mathrm{ft}$. Between altitudes of 40 and $30 \mathrm{ft}$, Punaluu Stream gained $0.2 \mathrm{ft}^{3} / \mathrm{s}$ on September 10, 2004, and lost 0.5, 0.4, and $0.02 \mathrm{ft}^{3} / \mathrm{s}$, respectively, on August 20, 2004, June 22, 2005, and August 4, 2005.

Between stream-channel altitudes of 30 and $10 \mathrm{ft}$, Punaluu Stream gains a few to several tenths of a cubic foot per second. Flows in Punaluu Stream at altitudes of 30 and $10 \mathrm{ft}$ and inflows between these altitudes were measured during the seepage runs of September 10, 2004 and August 4, 2005. Return flows from taro fields that receive water from Punaluu Ditch enter Punaluu Stream from the right bank of the stream near an altitude of about $15 \mathrm{ft}$, and potential tributary inflows may enter from either the left or right banks. Between altitudes of 30 and $10 \mathrm{ft}$, Punaluu Stream gained 0.7 and $0.2 \mathrm{ft}^{3} / \mathrm{s}$, respectively, on September 10, 2004 and August 4, 2005 (fig. 16).

Between altitudes of 10 and $5 \mathrm{ft}$, Punaluu Stream mainly gains water (as much as $1 \mathrm{ft}^{3} / \mathrm{s}$ ). Flows in Punaluu Stream at altitudes of 10 and $5 \mathrm{ft}$ were measured concurrently on 4 days in 2005. Between altitudes of 10 and $5 \mathrm{ft}$, Punaluu Stream lost $0.6 \mathrm{ft}^{3} / \mathrm{s}$ on June 22, 2005, and gained $0.9,0.7$, and 1.0 $\mathrm{ft}^{3} / \mathrm{s}$, respectively, on May 26, 2005, June 9, 2005, and August 4, 2005. The loss measured on June 22, 2005 may reflect variations in ground-water levels and ground-water discharge to the stream caused by ocean tides during a period of large tidal variation, although data are not available to verify this possibility. 


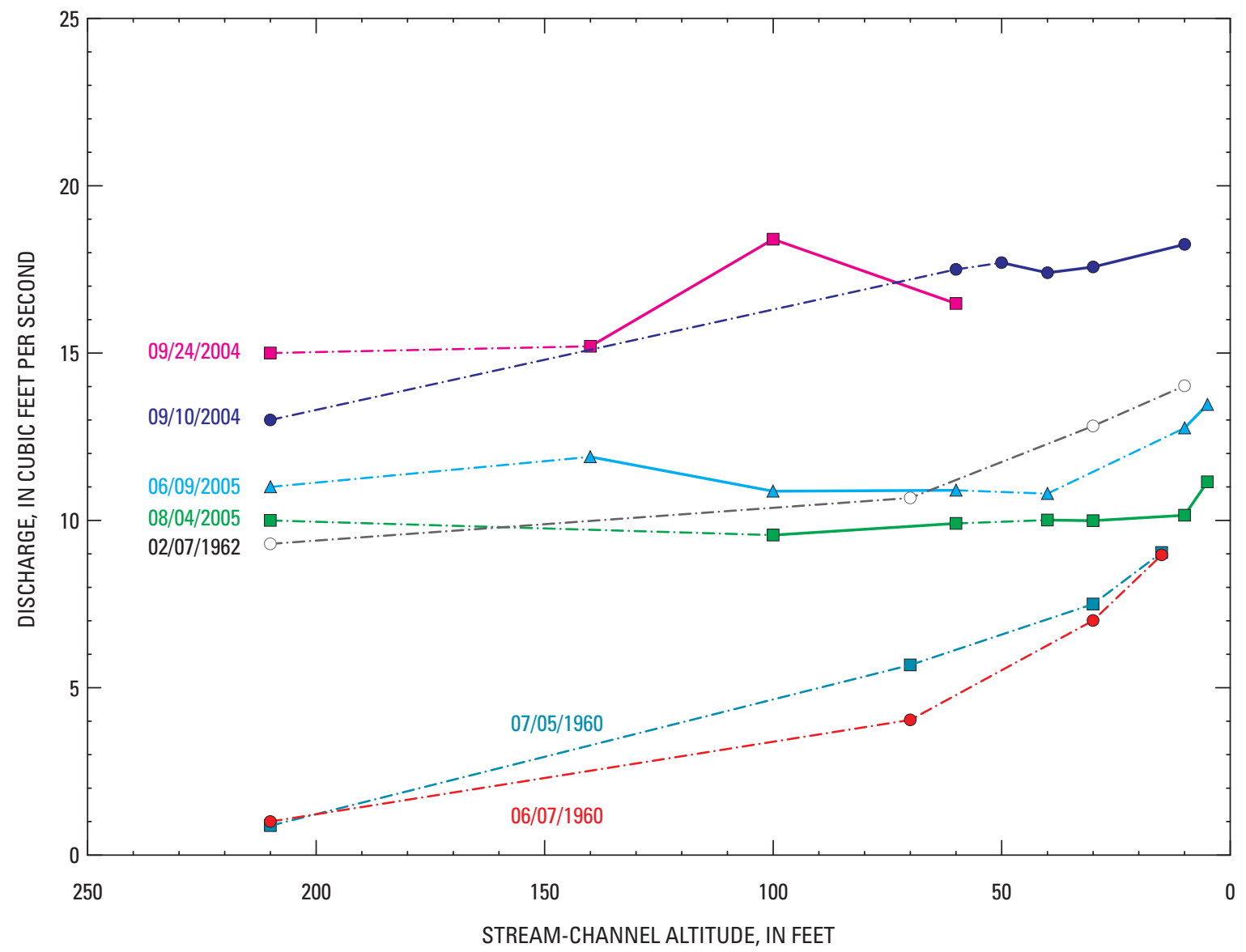

Figure 16. Streamflow variation (excluding measured tributary inflows and ditch return flows downstream from an altitude of $210 \mathrm{ft}$ ) with stream-channel altitude, Punaluu Stream, Oahu, Hawaii. Lines are dashed for cases in which tributary inflows between stream sites may not have been completely measured.

\section{Punaluu Ditch}

The Punaluu Ditch system consists of an intake near an altitude of about $210 \mathrm{ft}$ and 12 tunnels connected by sections of open channel (fig. 14). Most of the water in Punaluu Ditch is from the main intake on Punaluu Stream, although surface runoff also may enter the open-channel sections of the ditch system during periods of heavy rainfall. In addition, water may enter the ditch system during dry-weather conditions from at least two known locations: (1) from an opening in tunnel 2, and (2) between tunnels 4 and 5.

Water diverted from a small tributary that passes over tunnel 2 is channeled directly into an opening in tunnel 2 , about $50 \mathrm{ft}$ downstream from the tunnel entrance. The volume of water that enters the ditch system at this site is dependent on the flow in the tributary and the condition of the tunnel 2 intake screen, which may become blocked by debris. When the intake screen is effectively blocked by debris, water entering the ditch system from the tunnel 2 intake may be reduced to less than $0.01 \mathrm{ft}^{3} / \mathrm{s}$. When the tunnel 2 intake screen is clear of debris, inflow to the ditch system at this site probably can exceed $1 \mathrm{ft}^{3} / \mathrm{s}$, although the highest of three discharge measurements made during 2005 at the intake was $0.76 \mathrm{ft}^{3} / \mathrm{s}$.

The left wall (viewed in a downstream direction) of the ditch between tunnels 4 and 5 has an opening (about 6 in. wide) that can divert water from a small tributary that runs along the left wall of the ditch. Inflow at this site probably does not exceed a few tenths of a cubic foot per second, and may be considerably less if the opening becomes blocked by debris.

Water also may enter the ditch system from other engineered intakes, including a side tunnel that was observed within tunnel 3 , about $10 \mathrm{ft}$ from the tunnel 3 exit. The tunnels were not explored as part of this study because of the danger associated with potential tunnel collapse. Water also may enter the ditch system from seepage in the tunnels or the open-channel sections.

Water may be released from the ditch system through a series of removable gates near the tunnel portals and also through diversion pipes. A pipe intake that has been blocked originates near the entrance of tunnel 4 , and an unused, broken pipeline originates near the exit of tunnel 4. A pipeline 
originating between tunnels 5 and 6 serves a property near an altitude of about $90 \mathrm{ft}$. Two pipelines, one originating between tunnels 7 and 8 and a second between tunnels 9 and 10, supply water to aquaculture ponds above an altitude of $40 \mathrm{ft}$. A 16-in. pipeline originating between tunnels 9 and 10 provides water to users on Kamehameha Schools property lower in the valley, mainly south of Punaluu Stream. A pipeline originating downstream from tunnel 12 serves several users north of Punaluu Stream. Unused water at the end of the system enters a tributary and returns to Punaluu Stream about 1,300 ft from the coast.

\section{Punaluu Ditch Flow Characteristics}

Mean discharge in Punaluu Ditch measured at gaging station 16302000 between tunnels 1 and 2 during water years 1955-2004 was $8.43 \mathrm{ft}^{3} / \mathrm{s}$, which represents about 34 percent of the mean discharge available in Punaluu Stream measured by gaging station 16303003 . During 1955-2004, zero flow in Punaluu Ditch occurred on about 3 percent of the days and daily mean discharge exceeded $20 \mathrm{ft}^{3} / \mathrm{s}$ on about 2 percent of the days. During the recent period 1995-2004, mean discharge in Punaluu Ditch was $10.8 \mathrm{ft}^{3} / \mathrm{s}$, representing about 49 percent of the mean discharge available in Punaluu Stream measured by gaging station 16303003 during the period $\left(22.0 \mathrm{ft}^{3} / \mathrm{s}\right)$.

The median discharge in Punaluu Ditch during 19952004 was $11 \mathrm{ft}^{3} / \mathrm{s}$, whereas the $\mathrm{Q}_{95}$ discharge was $5.5 \mathrm{ft}^{3} / \mathrm{s}$ (fig. 17). The ratio of the $\mathrm{Q}_{95}$-to- $\mathrm{Q}_{50}$ discharges in Punaluu Ditch is 0.5 , reflecting fairly low variability in flow. During 1995-2004, daily mean discharge in the Ditch was less than $2 \mathrm{ft}^{3} / \mathrm{s}$ about 0.3 percent of the time. Flow in the Ditch varies partly in response to the water level in the stream at the intake. However, flow in the Ditch also is affected by conditions at the intake, which consists of a vertical grate with 13 bars separated by 1.9-inch open gaps. Leaves, small branches, and other debris carried by the stream commonly are trapped by and partially block the vertical grate, which reduces flow into the ditch system (fig. 18). The intake grate must be cleaned manually on a regular basis to maintain flow in the ditch system. After the intake grate is cleared of debris, flow in the Punaluu Ditch, as measured at gaging station 16302000, initially increases, but later decreases as the intake becomes partially blocked again (fig. 11). During periods of little or no rainfall, debris on the intake may cause flow in the Ditch to decrease at the rate of up to a few cubic feet per second per day. During periods of heavy rainfall, streamflow rises rapidly and flow in the ditch also may increase initially. However, because the amount of debris in the stream increases during periods of heavy rainfall, the intake grate for the Ditch traps a large amount of debris in a short period of time, and discharge in the Ditch may be reduced to $2 \mathrm{ft}^{3} / \mathrm{s}$ or less in an hour (fig. 11).

\section{Ditch Discharge Measurements}

Same-day discharge measurements were made in Punaluu Ditch to determine the general distribution of flow along the length of the ditch between tunnels 1 and 11 (fig. 14). Flow in the Ditch varies during the day in response to debris collecting at the main intake, controlled releases of water from the ditch system to water users in the valley, and changing conditions in Punaluu Stream. Thus, same-day discharge measurements may not always provide an accurate indication of the magnitude of increases and decreases of water along the ditch system because of variability of flow during the period of the measurements. For example, clearing the intake of trapped debris causes flow in the ditch system to increase near tunnel 2 within 15 minutes, but the increase in flow near tunnel 10 occurs more than 1 hour later. Nevertheless, the discharge measurements provide a general indication of flow conditions in the ditch on the days of the measurements.

In addition to the discharge obtained from the existing gaging station (16302000) between tunnels 1 and 2, discharge in the ditch system was measured at selected sites on 6 separate days in 2004 and 2005. Although measurements sometimes were made between tunnels 2 and 5, these measurements generally are considered of poor quality (possibly less than 8 percent accuracy) because of root growth in the ditch system at the time of the measurements or bends in the channel that affected the velocity distribution at the few available measuring sections. Thus, discharge measurements made between tunnels 2 and 5 were not used to characterize the distribution of flow in the ditch system, although the measured values are available (tables 1 and 2).

Between the gaging station (16302000) and the exit of tunnel 6, flow in Punaluu Ditch may either increase or decrease, depending on the magnitudes of inflows to the ditch system and outflows from release gates, overflowing sections, or diversions. Downstream from tunnel 6, flow in Punaluu Ditch generally decreases because of diversions, releases of water, or overflowing sections. Between the downstream ends of tunnels 6 and 9, discharge in Punaluu Ditch decreased by $1.17,1.30$, and $0.42 \mathrm{ft}^{3} / \mathrm{s}$, respectively, on June 23, 2004, February 15, 2005, and March 15, 2005. Between tunnels 9 and 11, discharge in Punaluu Ditch decreased by 6.86, 5.51, and $6.00 \mathrm{ft}^{3} / \mathrm{s}$, respectively, on February 8, 2005, February 15, 2005, and March 15, 2005. The large decrease in flow between tunnels 9 and 11 is caused by controlled diversion of water from the ditch system by water users in the valley and by overflowing water at release gates. Overflowing water between tunnels 9 and 11 returns to Punaluu Stream near an altitude of about $35 \mathrm{ft}$. On the basis of discharge measurements in the ditch system, the amount of water diverted between tunnels 6 and 10 for uses in the valley is estimated to range from about 2 to $4 \mathrm{ft}^{3} / \mathrm{s}$. Water flowing into tunnel 11 was measured on February 8, 2005, February 15, 2005, and March 15, 2005, and averaged $1.31 \mathrm{ft}^{3} / \mathrm{s}$, representing less than 15 percent of the discharge measured at gaging station 16302000 during the periods of the measurements. During the periods when 


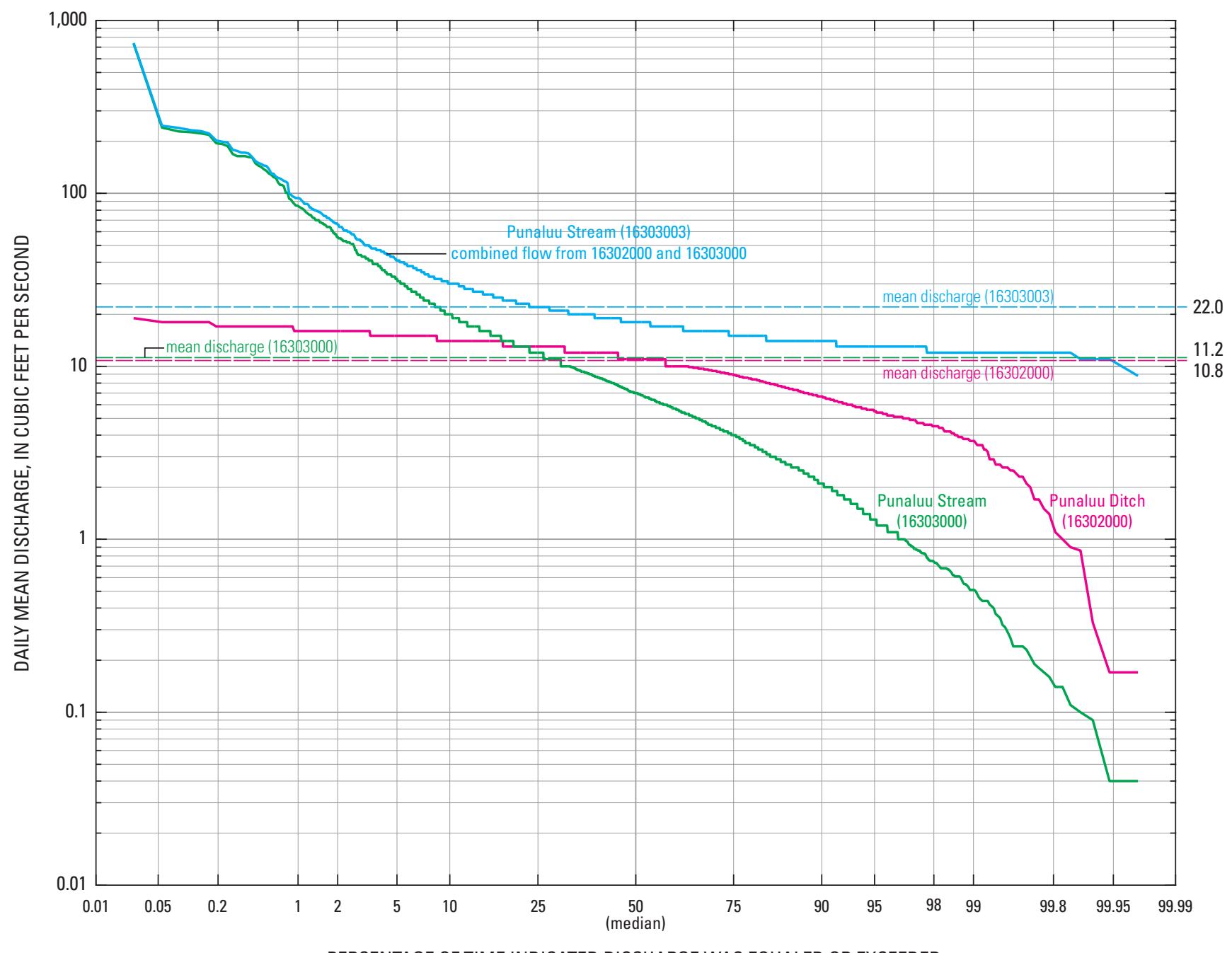

PERCENTAGE OF TIME INDICATED DISCHARGE WAS EQUALED OR EXCEEDED

Figure 17. Flow-duration curves for Punaluu Ditch (gaging station 16302000), Punaluu Stream (gaging station 16303000), and combined discharge from stations 16302000 and 16303000 (gaging station 16303003), water years 1995-2004, Oahu, Hawaii.

discharge measurements were made in the ditch system, tunnel 11 was partly obstructed by debris associated with a collapse within the tunnel.

\section{Stream Fauna}

Both native and non-native aquatic species can be found in Punaluu Stream. The isolation of the Hawaiian Islands resulted in the evolution of a unique native stream community. Recent human activities have resulted in the introduction of a number of non-native species into Punaluu Stream, and these non-native species may compete with native species for available resources. Native stream fauna utilize a variety of macro- and micro-habitats within stream ecosystems. The availability of suitable habitat for native fish, snails, and shrimp species found in Punaluu Stream is examined in a later section ("Effects of Surface-Water Diversion on Habitat") of this report.

In Hawaii, native invertebrate (molluscs and crustaceans) species include the endemic (found only in Hawaii) freshwater snail, Neritina granosa Sowerby 1825 , commonly referred to as hihiwai; the endemic brackish-water snail, Neritina vespertinus (Sowerby 1849), referred to as hapawai; the endemic prawn Macrobrachium grandimanus (Randall 1840), referred to as opae oehaa; and the endemic mountain shrimp, Atyoida bisulcata (Randall 1840), referred to as opae kalaole or mountain opae. Native vertebrate species include fish, collectively referred to as oopu. The five oopu include an endemic eleotrid (family: Eleotridae) Eleotris sandwicensis (Vaillant and Sauvage 1875), referred to as oopu akupa, and fishes in the family Gobiidae, collectively referred to as gobies, including the endemic gobies Lentipes concolor (Gill 1860), known as oopu 

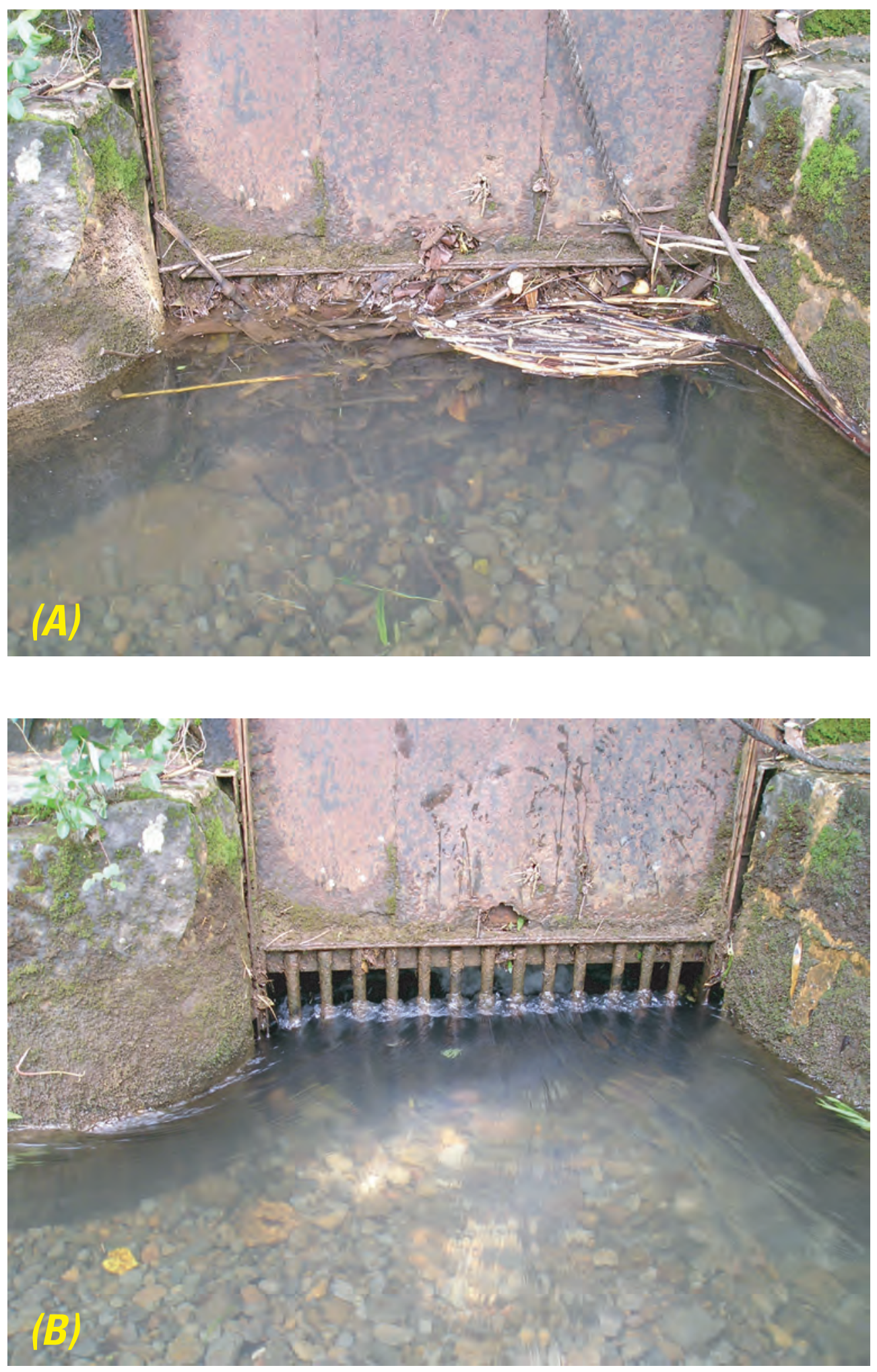

Figure 18. Photographs of the Punaluu Ditch intake near a stream altitude of about 210 feet on August 5, 2005, (A) prior to clearing the intake grate of debris and (B) after clearing the intake grate of debris. (Photographs by Delwyn S. Oki, U.S. Geological Survey.) 
alamoo (or hiukole); Sicyopterus stimpsoni (Gill 1860) known as oopu nopili; Stenogobius hawaiiensis, the teardrop goby also known as oopu naniha (Watson 1991); and the indigenous (native to Hawaii and elsewhere) goby Awaous guamensis (Valenciennes 1837), also known as oopu nakea. The juveniles of an endemic near-shore marine fish species, Kuhlia xenura (Jordan and Gilbert, 1882), also known as the Hawaiian flagtail or aholehole, are commonly found in lower stream reaches and estuaries.

\section{Life History Characteristics of Native Species}

A number of life-history characteristics factor into the habitat selection of native stream fauna in Hawaii. First, having evolved from marine ancestors, the species of interest for this study are all amphidromous, retaining a marine larval stage (McDowall, 1993; McDowall, 2003). Amphidromy is a type of diadromy that requires fauna to migrate between the freshwater stream and the ocean. Females deposit their eggs in streams, the eggs hatch and the larvae are carried downstream to the ocean where they live as zooplankton until they develop into post-larvae. The post-larvae then make their way back to freshwater streams where they eventually mature into adults and live the remainder of their lives (Ego, 1956; Tomihama, 1972; Ford and Kinzie, 1982; Kinzie and Ford, 1982; Kinzie, 1988; McDowall, 1988). The amphidromous life cycle requires unimpeded access to and from the ocean.

Another relevant life-history characteristic is the upstream migratory ability of the different species. Four of the five oopu, Stenogobius hawaiiensis, Awaous guamensis, Sicyopterus stimpsoni, and Lentipes concolor are true gobies and have fused pelvic fins. The fused pelvic fin forms a suction disk that enables these fishes to attach themselves to stream substrate and climb cascades and waterfalls (Kinzie and Ford, 1982). Differences in climbing abilities have allowed the native fish species to migrate upstream and inhabit stream reaches according to their relative abilities to cling to the stream substrate. Eleotris sandwicensis is not a true goby and lacks the fused pelvic fin and, therefore, is restricted to the lowest stream reaches, stream mouths, and estuaries. S. hawaiiensis has the weakest climbing ability and also is confined to the lower stream reaches, stream mouths, and estuaries. A. guamensis, the largest of the fish species, is a moderate climber and commonly is found in lower and middle stream reaches. S. stimpsoni often inhabits the middle stream reaches, whereas L. concolor, the best climber, typically is found in middle and upper stream reaches (Nishimoto and Fitzsimons, 1986; Fitzsimons and Nishimoto, 1990a; Kinzie, 1990). The mountain opae Atyoida bisulcata have exceptional climbing ability and most often inhabit the upper stream reaches (Couret, 1976; Kinzie, 1990). Neritina granosa commonly are found in lower stream reaches but can be found in reaches up until the first large waterfall (Ford, 1979; Kinzie, 1990). Neritina vespertinus and Macrobrachium grandimanus are restricted to the lower stream reaches and estuaries. Segre- gation along elevation and longitudinal gradients reduces the amount of competition among species for resources.

Another factor in habitat selection involves territoriality. Mature Lentipes concolor males have been observed to aggressively defend territories against male conspecifics (males of the same species), whereas females tend to move freely about the stream (Lau, 1973; Maciolek, 1977; Nishimoto and Fitzsimons, 1986; Fitzsimons and Nishimoto, 1990b). Similarly, male Sicyopterus stimpsoni aggressively defend territories, with larger fish defending larger territories (Fitzsimons and Nishimoto, 1990a; Fitzsimons and others, 1993). The normally docile Awaous guamensis exhibits aggressive territoriality toward conspecifics as well as other species during the fall spawning season (Fitzsimons and Nishimoto, 1990a).

Dietary preferences of the stream fauna also can influence habitat selection. The heterogeneous nature of streams may make it possible for species to occupy the same stream macrohabitats because microhabitats commonly have different dietary resources. Morphological adaptations of the fishes may have functionally served to reduce interspecific competition for resources and allow the fish species to coexist (Kido, 1996a; Kido, 1997a; Kido, 1997b). Heterogeneous algal and invertebrate assemblages in Hawaiian streams provide a diversity of dietary resources for fish species of various age classes to utilize.

\section{Native Species in Punaluu Stream}

In a statewide inventory of streams conducted in Hawaii in the 1970s (Timbol and Maciolek, 1978) Punaluu Stream was rated as "Limited Consumptive," defined as having moderate to high-quality water, with controlled use to prevent excessive modification. Punaluu Stream was listed as having eight diversions and six road crossings. A survey of stream fauna was not conducted at the time.

The Hawaii Stream Assessment (HSA), a cooperative project that attempted to identify streams and rivers in Hawaii with significant natural and cultural qualities, rated Punaluu Stream as having “Outstanding” aquatic resources and "Excellent" native diversity based on the presence of native species (Hawaii Cooperative Park Service Unit, 1990). The HSA classified 11 native stream species into two groups. Native Group 1 (NG1) consisted of "indicator species" considered representative of potentially high-quality stream ecosystems. Native Group 2 (NG2) consisted of native stream species considered more common and typical of a healthy native stream ecosystem. The HSA surveys of Punaluu Stream included three NG1 species: Neritina granosa, Sicyopterus stimpsoni, and Awaous guamensis, and five NG2 species: Eleotris sandwicensis, Atyoida bisulcata, Macrobrachium grandimanus, Stenogobius hawaiiensis, and Kuhlia xenura (revised species name from sandvicensis) (table 4).

As part of the USGS National Water Quality Assessment program (NAWQA), habitat, fish, and invertebrate data were collected at two sites on Punaluu Stream near gaging station 16303000 in 1999 (Brasher and others, 2004; U.S. Geologi- 
cal Survey, 2005). The lower site (PUNB) was located at an altitude of about $200 \mathrm{ft}$, immediately downstream from the diversion intake for Punaluu Ditch near an altitude of $210 \mathrm{ft}$. The upper site (PUNA) was located immediately upstream from the diversion intake. Atyoida bisulcata and Awaous guamensis were observed upstream from the diversion, whereas A. guamensis was the only native species observed at the lower site (table 4). Larvae of four native species, Eleotris sandwicensis, Stenogobius hawaiiensis, A. guamensis, and Macrobrachium grandimanus were identified in larval-drift samples collected near the coast at the highway bridge in 1999 and 2000 as part of the NAWQA program (Luton and others, 2005) (table 4).

Data from Hawaii's Division of Aquatic Resources (DAR) Freshwater Database recorded observations of Neritina granosa, Atyoida bisulcata, Macrobrachium grandimanus, Eleotris sandwicensis, Stenogobius hawaiiensis, Awaous guamensis, Lentipes concolor, and Kuhlia xenura in Punaluu Stream during point-quadrat count surveys conducted in 2002 and 2003 (table 4) (State of Hawaii, 2004).

As part of this study, abundances of species were determined using snorkel surveys at selected reaches on Punaluu Stream during 2004 (fig. 19). Snorkelers entered the stream below the downstream end of the study reach and slowly moved upstream and recorded all of the observed fish and shrimp species and their abundances for the entire stream reach (table 5). The abundances of Neritina granosa (hihiwai) were determined by sight and by overturning and inspecting selected rocks while snorkeling and, therefore, observed counts may underestimate actual abundances. Additional snorkel surveys were conducted in 2004 and 2005 at various locations along the stream to an altitude of about $400 \mathrm{ft}$ to provide supplemental information on the distributions of aquatic species (fig. 19), although species abundances were not recorded during these additional surveys. Survey results indicate that Awaous guamensis were found upstream from the Punaluu Ditch diversion intake near an altitude of $210 \mathrm{ft}$, whereas Eleotris sandwicensis and Stenogobius hawaiiensis were not found above an altitude of $50 \mathrm{ft}$.

The HSA reported that Awaous guamensis were very abundant in Punaluu Stream in 1989. However, during the NAWQA electrofishing survey A. guamensis were not very abundant. In the 1999 NAWQA survey, only four A. guamensis were observed downstream from the Punaluu Ditch diversion intake and only six were observed upstream from the diversion intake. The number of A. guamensis appears to have increased since the 1999 NAWQA survey. In the 2004 snorkel surveys, 17 A. guamensis were observed downstream from the diversion intake and 33 were observed upstream from the intake (table 5). More than half of the observed A. guamensis were 3 in. long (total length) or smaller. This suggests that recruitment of A. guamensis to an altitude of $200 \mathrm{ft}$ in Punaluu Stream has been more successful since the time of NAWQA surveys during 1999.
The DAR Freshwater Database had one record from a 2002 survey for Lentipes concolor in Punaluu Stream at an altitude of $235 \mathrm{ft}$, upstream from the diversion intake. L. concolor was not observed during the NAWQA surveys or during the current USGS study. Timbol and others (1980) considered L. concolor to be "functionally extinct" on Oahu because it had not been observed in Oahu streams during a number of surveys dating as far back as the 1930s. Although later surveys recorded sightings of $L$. concolor in Oahu streams, it is still rarely observed and is considerably less abundant than in streams on the other main Hawaiian islands (Higashi and Yamamoto, 1993; Brasher, 2003). The HSA reported that Sicyopterus stimpsoni was present in Punaluu Stream in 1989. However, S. stimpsoni was not observed in the 1999 NAWQA surveys, the 2002-2003 DAR surveys, or the surveys from this study. Timbol and others (1980) reported that S. stimpsoni was rarely found on Oahu. Kinzie (1990) also noted that S. stimpsoni had become rare on Oahu, with only a few observations recorded from the few remaining unaltered Oahu streams.

\section{Non-Native Species}

Over the years, many non-native species have been introduced into Hawaiian streams. More than 50 aquatic animal species, excluding insects, have become established in Hawaii (Devick, 1991). The list of non-native species observed in Punaluu Stream include: aquatic snails such as Melanoides tuberculata (Müller 1774), and Tarebia granifera (Lamarck 1822); the Tahitian prawn, Macrobrachium lar (Fabricius 1798); the Louisiana crayfish, Procambarus clarkii (Girard 1852); fish from the family Poeciliidae including the western mosquitofish, Gambusia affinis (Baird and Girard 1853), guppies, Poecilia reticulata Peters 1859, and green swordtails, Xiphophorus helleri Heckel 1848; the convict cichlid, Cichlasoma nigrofasciatum (Günther 1867); the banded jewel cichlid, Hemichromis elongatus (Guichenot 1858); a number of tilapia species including Oreochromis cf. mossambicus (Peters 1852); the Chinese catfish, Clarius fuscus (Lacepède 1803); and carp (table 6). Some of these species, such as G. affinis, were intentionally released for mosquito control, whereas others, such as carp species and $H$. elongatus, may be accidental escapees from aquaculture or have been released from home aquaria, respectively, (Van Dine, 1907; Devick, 1991; Yamamoto and Tagawa, 2000).

The HSA classified non-native species into two groups based on their potential to threaten native species (Hawaii Cooperative Park Service Unit, 1990). Non-native species group 1 (IG1) included non-native species that threaten native species by predation or competition. Non-native species group 2 (IG2) included non-native species that are not harmful to native species. HSA surveys of Punaluu Stream during the 1980s included records of IG1 species: Xiphophorus helleri, Clarius fuscus, Poecilia spp., and Tilapia spp., and IG2 species: Melanoides tuberculata and Macrobrachium lar (table 6). 


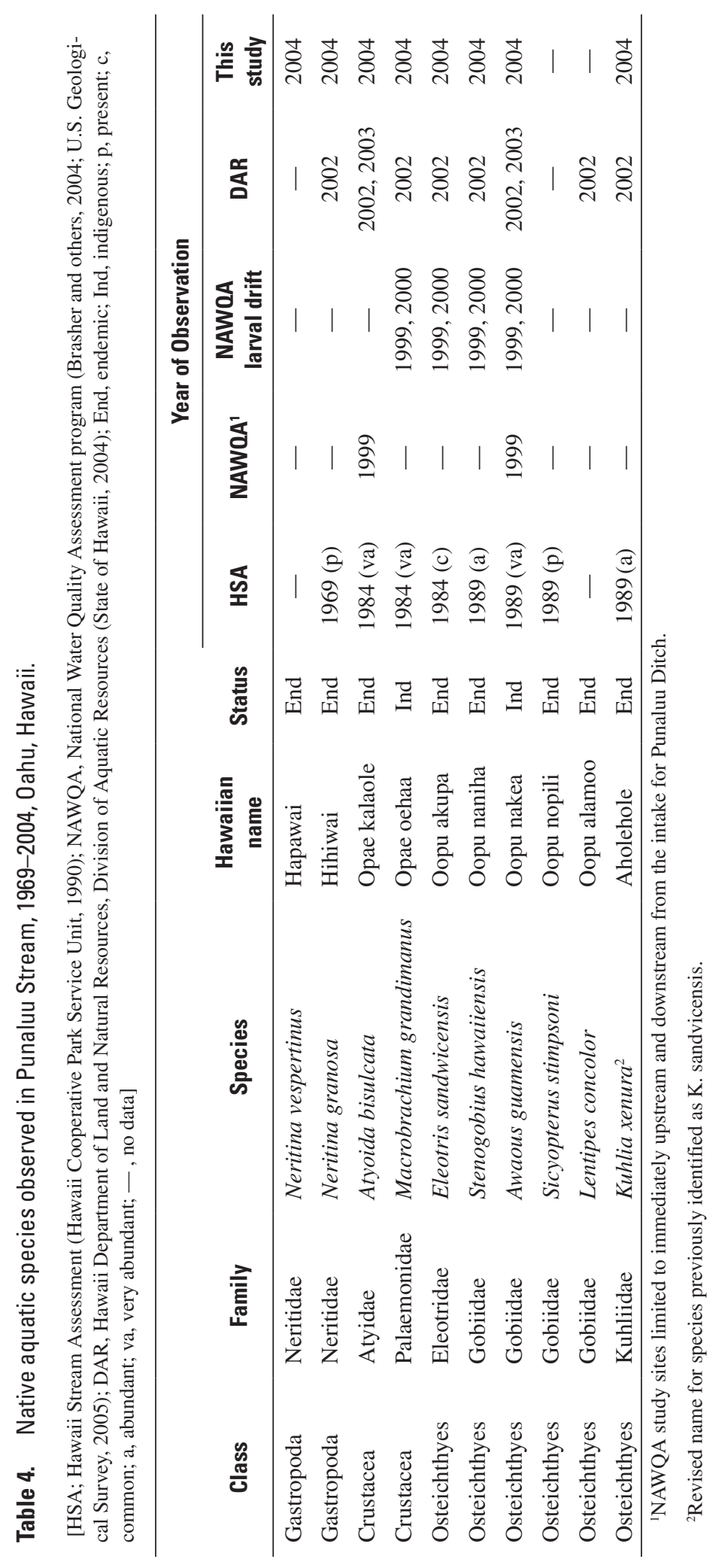


$157^{\circ} 54^{\prime}$

$157^{\circ} 53^{\prime}$

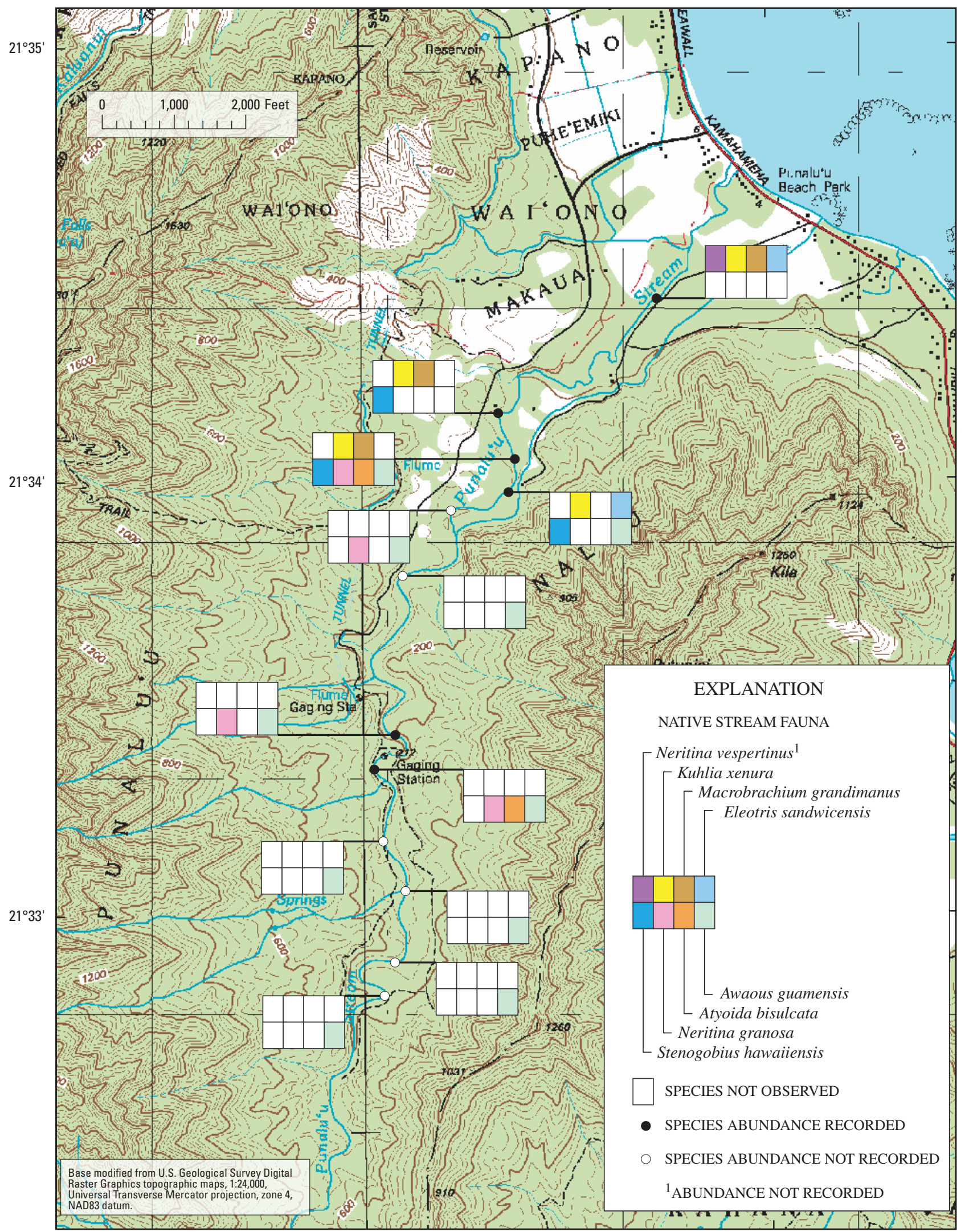

Figure 19. Native species observed in Punaluu Stream during 2004 and 2005, Oahu, Hawaii. 


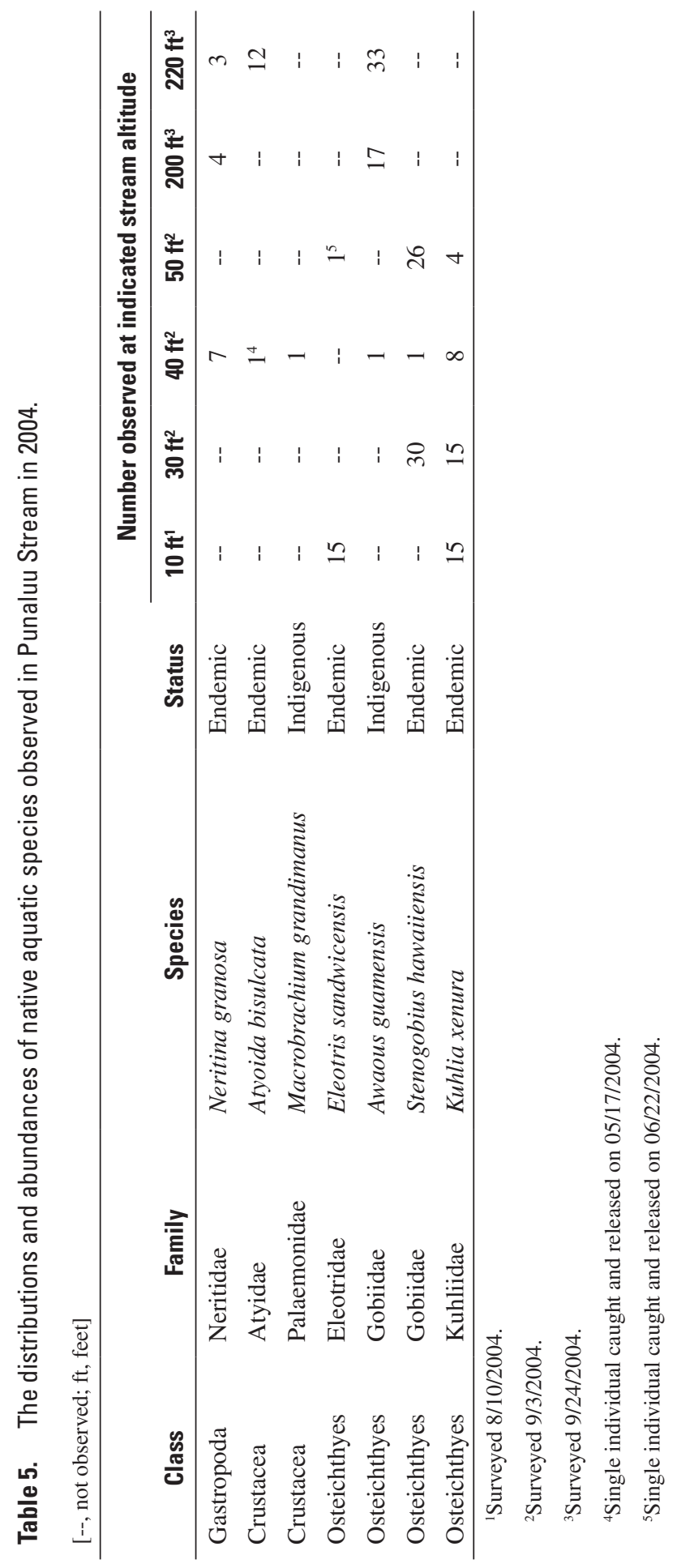




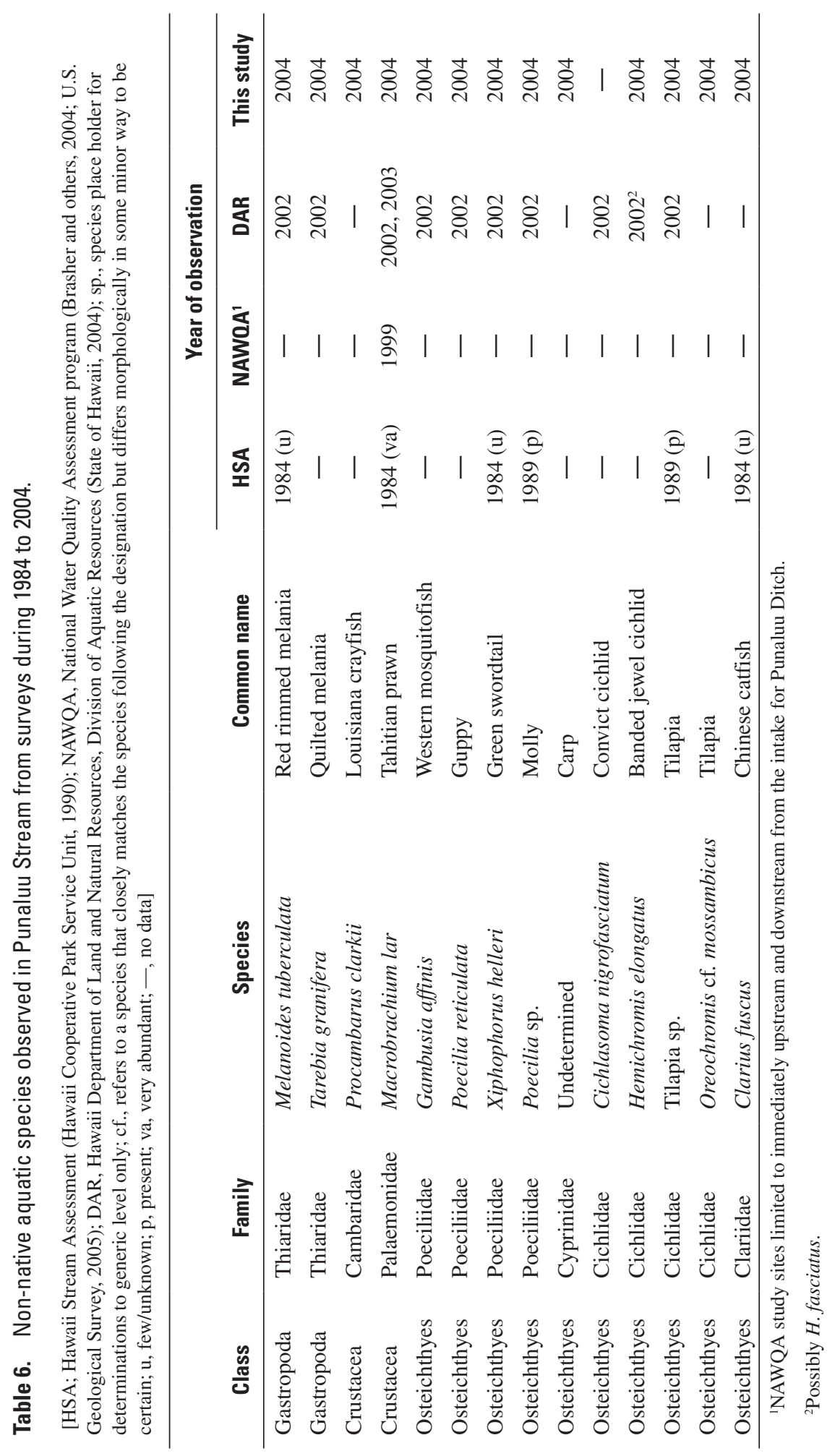


The only non-native species observed immediately upstream and downstream from the Punaluu Ditch diversion intake during the 1999 NAWQA surveys was M. lar. The DAR Freshwater Database listed 10 non-native species observed in Punaluu Stream in 2002 and 2003 (table 6).

Except for Cichlasoma nigrofasciatum, all of the nonnative species listed in table 6 were observed in Punaluu Stream during this study in 2004 and 2005 (fig. 20). Hemichromis elongatus, which had not been observed until the 2002 DAR survey, has now been observed immediately downstream from the Punaluu Ditch diversion intake (table 7). Poeciliids were not observed immediately upstream or downstream from the diversion intake during the extensive 1999 NAWQA surveys, but now have been observed well upstream from the intake (table 7).

\section{Potential Factors Affecting Abundance of Native Species}

The availability of physical habitat and water temperature may affect the abundance of native species in Punaluu Stream. The relation between streamflow and physical habitat for selected native species and measured stream temperatures along Punaluu Stream are described in later sections of this report. In addition to physical habitat and temperature, other factors that may affect the abundance of native species in Punaluu Stream include the presence of non-native species and land-use activities in areas adjacent to the stream.

\section{Non-Native Species}

Non-native species may have an effect on the abundances of native stream species in Punaluu Stream. Predaceous fishes such as Hemichromis elongatus and Clarius fuscus opportunistically prey upon stream fauna that likely include native species. The small-sized native juvenile recruits are especially vulnerable to predation during their upstream migration. Nonnative fish species also may prey upon eggs and tiny larvae of native amphidromous species as they drift downstream (Timbol and others, 1980). The population of H. elongatus is relatively new to Punaluu Stream and has apparently been spreading upstream where it had not been observed in the 1999 NAWQA surveys. The long-term effect of this predator on the native community is unknown.

To investigate whether non-native fish were preying upon native fauna, the stomach contents of eight Hemichromis elongatus, one Clarius fuscus, and three tilapia were examined under a microscope. H. elongatus and C. fuscus are both highly predacious, feeding on small fishes, crustaceans, and insects (Yamamoto and Tagawa, 2000). The H. elongatus ranged from 5 to $7 \mathrm{in.}$ in total length and from 30 to 120 grams in weight. The majority of the H. elongatus had faunal remains in their stomachs, including remnants of isopods, amphipods, shrimp, chironomids (insect larvae), small fish, and terrestrial arthropods such as grasshoppers as well. The C. fuscus (12 in. total length, 234 grams in weight) had remains of a prawn (most probably Macrobrachium lar) in its stomach. Although no remains of native species definitively could be identified in the stomach contents, the presence of faunal remains indicates that predation by the non-native fish species $C$. fuscus and $H$. elongatus has the potential to affect native fish and shrimp populations in Punaluu Stream. The tilapia were approximately $1 \mathrm{ft}$ long (total length) and weighed between 400 to more than 600 grams. None of the three tilapia had any discernable faunal remains in their stomachs. Their diet was comprised of vegetative matter.

Additionally, three of the eight $H$. elongatus were infected with the intestinal parasite Camallanus cotti, a nematode of the family Camallanidae. C. cotti is a roundworm that was accidentally introduced to Hawaii with the introduction of infected poeciliid fishes such as Gambusia affinis (Font, 1997a). This widespread parasite has been found in the intestines of native fish in streams that also have introduced poeciliids (Font, 1997b). This parasite poses a threat to native Hawaiian stream fishes (Font, 1997b) and can detrimentally affect the health of the infected fishes causing reduced fecundity, reduced ability to avoid predators, and fatal secondary infections (Post, 1987).

Non-native species may directly or indirectly affect the native species by competing for resources (Vitousek and others, 1987). A number of resilient, non-native species such as the poeciliid fishes and tilapia are prolific breeders with extended breeding seasons and can rapidly increase in population, putting a strain on available resources. These non-native species can compete with native species for space or food resources. Non-native species also can directly alter habitat for native species. For example, the crayfish Procambarus clarkii is known to burrow into stream banks causing increased erosion and sedimentation that can affect the native fishes.

\section{Agricultural Activities}

Agricultural land-use has been associated with increases in sediments, nutrients, and contaminants in streams (Pajak and others, 1994; Cuffney and others, 1997; Allan, 2004). These changes in water quality can directly or indirectly affect stream fauna. Increases in deposited sediment can reduce or eliminate suitable habitats utilized by native species (Ryan, 1991; Wood and Armitage, 1997). The reproductive success of some fish species may be impeded by increased suspended or deposited sediments (Wood and Armitage, 1997; Burkhead and Jelks, 2001). Increased turbidity and siltation can reduce sunlight available to photosynthetic algae, an important component of the diet of some native species (Couret, 1976; Kido and others, 1993; Kido, 1996b, 1997a, 1997b), and thereby inhibit the ability of some algae to colonize or grow (Wood and Armitage, 1997). Increased nutrient concentrations can lead to a change in the algal-community species (Allan, 2004).

Pesticide residues attached to agricultural sediments may be transported into adjacent surface waters (Nowell and others, 1999). These contaminants can enter the food web and bioac- 
$157^{\circ} 54^{\prime}$

$157^{\circ} 53^{\prime}$

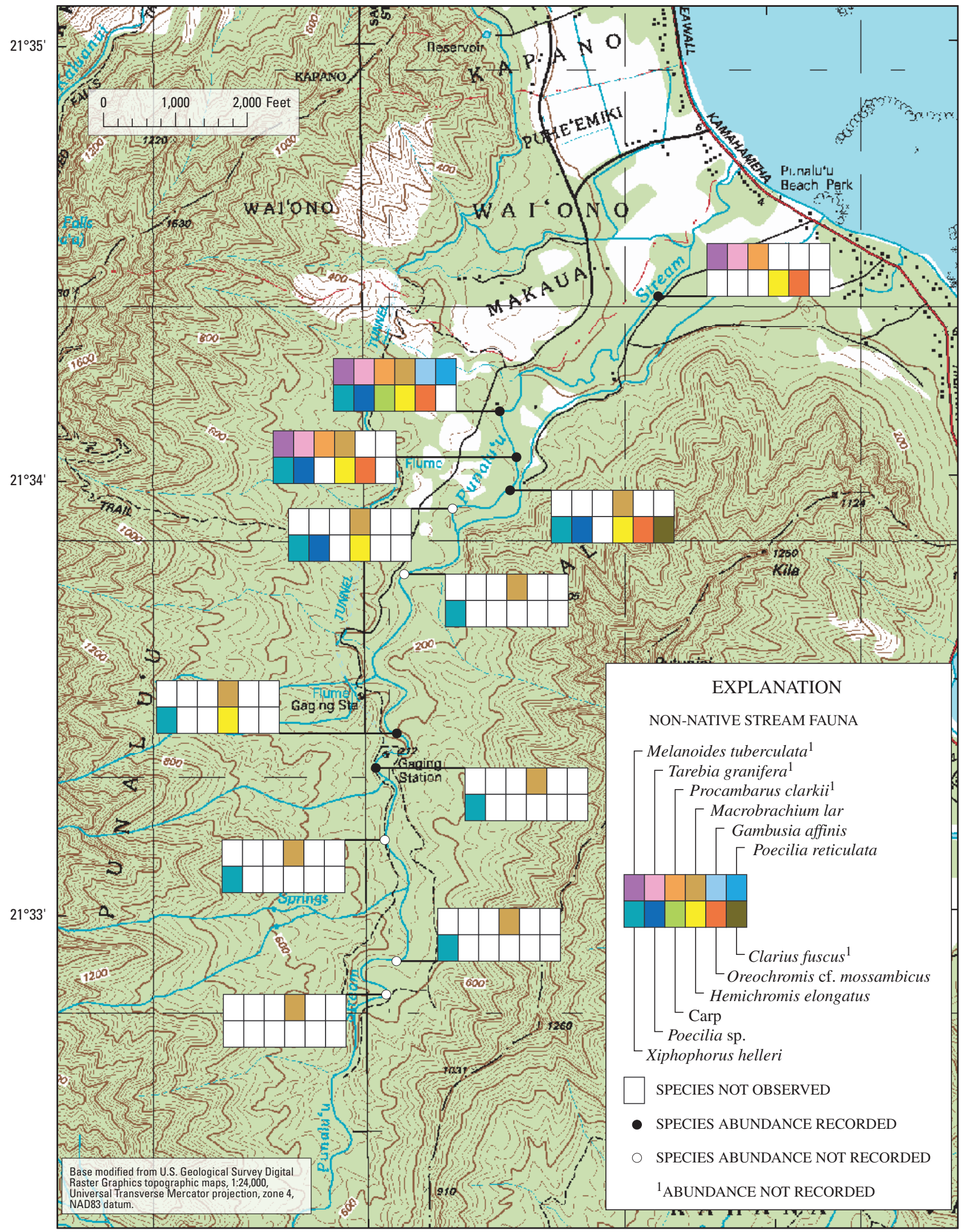

Figure 20. Non-native species observed in Punaluu Stream during 2004 and 2005, Oahu, Hawaii. 


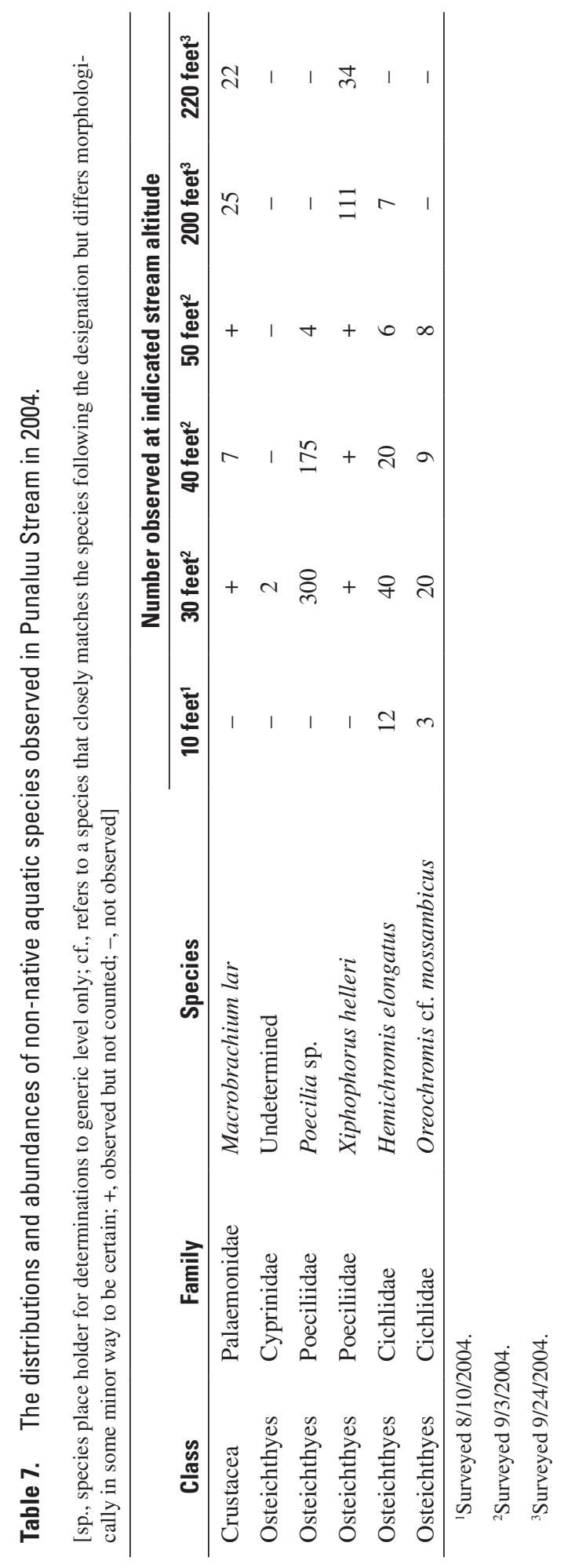


cumulate in the tissue of stream organisms (Chapman and others, 1998; Nowell and others, 1999; Brasher and Anthony, 2000; Wong and others, 2001; Brasher and Wolff, 2004) and possibly have deleterious effects on the fishes (Murty, 1986; Colborn and Thayer, 2000).

\section{Aquaculture}

Aquaculture can affect the water quality of adjacent streams by discharging effluent into the aquatic ecosystem (Kreeger, 2000). Non-native species may escape from aquaculture systems and enter surrounding stream systems. For example, the blackchin tilapia Sarotherodon melanotheron accidentally escaped from an aquaculture facility into a nearby surface-water body on Oahu during the 1960s (Randall, 1987; Devick, 1991; Nico, 2006). S. melanotheron was then transported to other streams and estuaries by humans and is now extremely abundant around Oahu (Devick, 1991; Yamamoto and Tagawa, 2000). Furthermore, the introduction of nonnative fishes for aquaculture has the potential to inadvertently introduce unwanted parasites that may infect native stream fauna (Font, 1997a, 1997b).

Additional studies designed to investigate water quality and contaminants in bed sediment and fish tissue may shed some light on the distribution and abundance of native species in Punaluu Stream. Further study of conditions in the estuary of Punaluu Stream also would help to identify factors that may affect populations of native species. Recruitment studies near the mouth of Punaluu Stream and at locations farther upstream would be useful to identify possible limiting reaches of the stream that control upstream migration of native species.

\section{Effects of Surface-Water Diversion on Streamflow}

Water in Punaluu Stream is currently being diverted by Punaluu Ditch for off-stream uses. The main diversion intake of Punaluu Ditch is on the left bank of Punaluu Stream at an altitude of about $210 \mathrm{ft}$. Diversion of surface water near an altitude of $210 \mathrm{ft}$ reduces streamflow downstream from the intake, although the reduction is somewhat offset by tributary inflows, return flows from Punaluu Ditch, and ground-water discharge to the stream at lower altitudes.

\section{Immediately Downstream from Punaluu Ditch Diversion (210-Feet Altitude)}

The effects of surface-water diversion on Punaluu Stream near an altitude of $210 \mathrm{ft}$ can be determined from the longterm records of stream-gaging stations 16303000 (which measures discharge in Punaluu Stream downstream from the diversion intake) and 16303003 (which measures discharge in Punaluu Stream upstream from the intake). During water years 1995-2004, mean discharges measured at gaging stations 16303000 and 16303003 , respectively, were 11.2 and $22.0 \mathrm{ft}^{3} / \mathrm{s}$. During water years 1995-2004, the $\mathrm{Q}_{50}, \mathrm{Q}_{90}$, and $\mathrm{Q}_{95}$ discharges measured at gaging station 16303003 , respectively, were 18,14 , and $13 \mathrm{ft}^{3} / \mathrm{s}$, whereas the $\mathrm{Q}_{50}, \mathrm{Q}_{90}$, and $\mathrm{Q}_{95}$ discharges measured at gaging station 16303000, respectively, were 7.0, 2.1, and $1.3 \mathrm{ft}^{3} / \mathrm{s}$ (fig. 17). Lower flows in Punaluu Stream are affected by the diversion of surface water to a relatively greater extent than higher flows. For example, the median discharge $\left(\mathrm{Q}_{50}\right)$ in Punaluu Stream is reduced to 39 percent of the natural median discharge, whereas the $Q_{90}$ and $\mathrm{Q}_{95}$ discharges, respectively, are reduced to 15 and 10 percent of their natural values. During water years 1995-2004, daily mean discharge at gaging station 16303000 was never zero, although flow in Punaluu Stream immediately downstream from the diversion intake may have been zero during parts of days for which the daily mean discharge was greater than zero. During water years 1995-2004, the minimum daily mean discharge measured at gaging station 16303000 was $0.04 \mathrm{ft}^{3} / \mathrm{s}$. During the same period, the minimum daily mean discharge measured at gaging station 16303003 was $8.8 \mathrm{ft}^{3} / \mathrm{s}$.

For this study, data from water years 1995-2004 (the base period) were used to characterize recent-flow conditions. This period was selected because: (1) it excludes the period prior to the 1970s when diversion practices for sugarcane irrigation may have differed from recent practices; (2) it excludes the period from about 1971-1986 when the volume of water diverted from Punaluu Stream was considerably less than during the more recent period from 1995-2004 (fig. 8); and (3) it excludes the period from 1991-1994 when the dam control structure immediately downstream from the diversion intake was partly destroyed by a flood. During the period 1995-2004, low flows from $\mathrm{Q}_{95}$ to $\mathrm{Q}_{50}$ discharges measured at stream-gaging station 16303003 were within about 10 percent of the corresponding long-term low flows during 1955-2004 (fig. 21).

\section{Altitudes of 140 to 10 Feet}

Long-term continuous streamflow data are not available from multiple sites to determine the spatial effects of diversion on flow in Punaluu Stream; however, low-flow partial-record (LFPR) stations can be used to estimate streamflow characteristics at sites without a long-term stream-gaging station. For example, Fontaine and others (1992) used data from LFPR stations on windward Oahu perennial streams to estimate median discharges at ungaged, regulated sites. Fontaine (2003) also used LFPR stations to estimate discharges, within the $\mathrm{Q}_{50}$ to $\mathrm{Q}_{95}$ range, in Honokohau Stream, Island of Maui, Hawaii. For this study, LFPR stations at altitudes of 10, 40, 100, and $140 \mathrm{ft}$ were used to estimate flow characteristics at sites on Punaluu Stream without long-term gaging stations. 


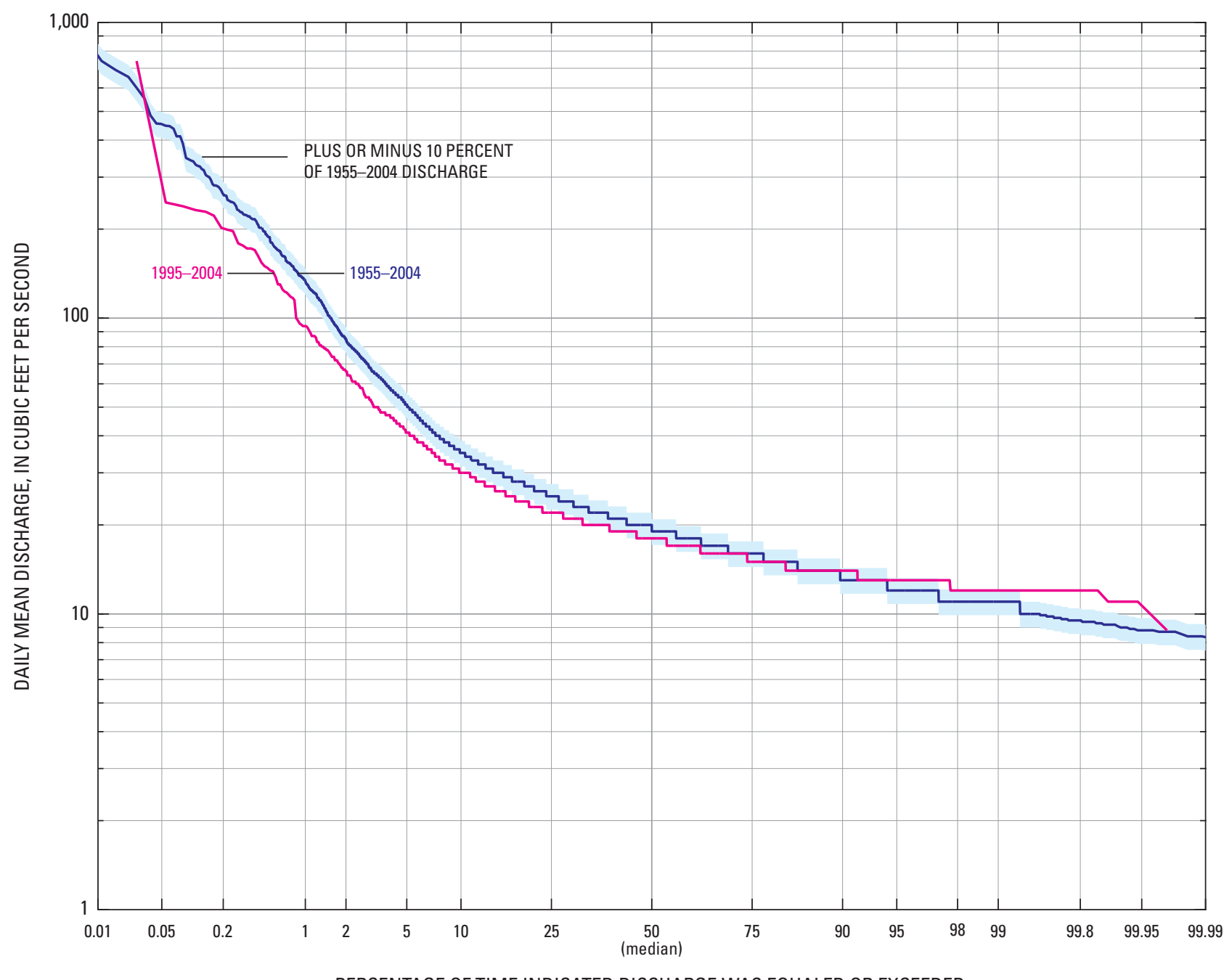

PERCENTAGE OF TIME INDICATED DISCHARGE WAS EQUALED OR EXCEEDED

Figure 21. Flow-duration curves for Punaluu Stream (gaging station 16303003) for water years 1955-2004 and 1995-2004, Oahu, Hawaii.

\section{Methods}

At LFPR stations, a minimum of about 10 discharge measurements generally are made during periods of low flow. These measurements are best made during independent recessions following periods of direct runoff, and cover a range of low-flow conditions. The measured discharges at each LFPR station are correlated with the concurrent discharges at a longterm index station with hydrologically similar characteristics. For this study, the index stations used were both from Punaluu Stream (16303000 and 16303003). Measured discharges at a LFPR station commonly are correlated with daily mean discharges at the index station. However, daily mean discharges recorded at gaging station 16303000 may reflect decreases in flow associated with cleaning of the Ditch intake following a discharge measurement at the LFPR station. In addition, daily mean discharges recorded at stations 16303000 and 16303003 may reflect increases in flow associated with periods of rainfall following a discharge measurement at the LFPR station. Because of the oftentimes variable nature of flow at the index stations on the same day as, but following, measurements of discharge at a LFPR station, discharges at the LFPR station were correlated with mean discharges at stations 16303000 and 16303003 during the 3-hr period prior to the start of the discharge measurement at the LFPR station.

A graphical-correlation method (Searcy, 1959) or the maintenance of variance extension, type 1 (MOVE.1) method (Hirsch, 1982) may be used to determine the relation between concurrent discharges at the LFPR and index stations. The graphical-correlation method is used for cases in which curvature is detected in the relation between the concurrent discharges, whereas the MOVE.1 method is used for cases in which little or no curvature exists in the relation between the concurrent discharges (see for example Ries, 1993). For this 
study, the mathematical MOVE.1 method was used because the relations between discharges at the LFPR stations and index stations showed little or no curvature.

In the MOVE. 1 method, the base-10 logarithms of the discharges at the LFPR station and the concurrent discharges at the index station are first computed. The means and standard deviations of the base-10 logarithm-transformed discharges are then determined. The base-10 logarithms of selected flow statistics (for example the $\mathrm{Q}_{50}$ or $\mathrm{Q}_{90}$ flow-duration discharges for a desired base period) at the index station also are determined. The corresponding flow statistics at the LFPR station are determined using the MOVE.1 equation:

$$
Y_{\mathrm{i}}=m_{y}+\left(s_{y} / s_{x}\right)\left(X_{\mathrm{i}}-m_{x}\right)
$$

where:

$Y_{\mathrm{i}} \quad$ is the base-10 logarithm of the estimated flowduration discharge at the LFPR station,

$X_{\mathrm{i}} \quad$ is the base-10 logarithm of the flow-duration discharge at the index station,

$m_{x} \quad$ is the mean of the base-10 logarithms of the discharge values at the index station,

$m_{y} \quad$ is the mean of the base-10 logarithms of the discharge values at the LFPR station,

$s_{x} \quad$ is the standard deviation of the base- 10 logarithms of the discharge values at the index station, and

$s_{y} \quad$ is the standard deviation of the base- 10 logarithms of the discharge values at the LFPR station.

For this study, 10 to 18 discharge measurements were made at each of the four LFPR stations on Punaluu Stream (tables 8-11). However, not all discharge measurements were used in the MOVE.1 method because (1) some measurements were made during periods when direct runoff may have contributed to total flow, and (2) clearing of the ditch-system intake made it difficult to correlate some stream-discharge measurements with recorded discharges at the existing gages. For LFPR stations at altitudes of 10,40 , and $100 \mathrm{ft}, 11$ or 12 discharge measurements were used in the MOVE.1 equation (tables 8-10). For the LFPR station at $140 \mathrm{ft}$, however, only seven discharge measurements were used (table 11).

For altitudes greater than $10 \mathrm{ft}$, LFPR-station discharges had high correlation with discharges at gaging station 16303000, which measures the discharge remaining in Punaluu Stream downstream from the diversion intake. For the LFPR station at an altitude of $10 \mathrm{ft}$, the LFPR-station discharges were correlated with discharges at gaging station 16303003, which measures total discharge in Punaluu Stream upstream from the diversion intake. Near an altitude of $10 \mathrm{ft}$, discharges in Punaluu Stream show greater correlation with discharges at gaging station 16303003 than 16303000 because of ditch-return flows to the stream above an altitude of $10 \mathrm{ft}$. The other LFPR stations are upstream from sites where large ditch-return flows enter the stream. The flow-duration discharges for recent water years 1995-2004 at gaging stations
16303000 and 16303003 were used to estimate corresponding flow-duration discharges at the LFPR stations. For this study, natural flows were estimated by multiplying the flow-duration discharges from stream-gaging station 16303003 by a constant factor that accounts for the increase in discharge between station 16303003 and the downstream LFPR station.

\section{Flow Characteristics for Diverted Conditions}

The 1995-2004 flow characteristics from gaging station 16303000, near an altitude of $210 \mathrm{ft}$, reflect flows in Punaluu Stream for recent diverted conditions near that altitude. During 1995-2004, the median discharge from gaging station 16303000 was $7.0 \mathrm{ft}^{3} / \mathrm{s}$. In comparison, the estimated median discharges at altitudes of 140, 100, 40, and $10 \mathrm{ft}$, respectively, are 7.7, 8.8, 10, and $18 \mathrm{ft}^{3} / \mathrm{s}$ (tables 12-15; fig. 22). During 1995-2004, the $\mathrm{Q}_{95}$ discharge from gaging station 16303000 was $1.3 \mathrm{ft}^{3} / \mathrm{s}$. In comparison, the estimated $\mathrm{Q}_{95}$ discharges at altitudes of 140, 100, 40, and $10 \mathrm{ft}$, respectively, are 1.5, 2.3, 2.6, and $11 \mathrm{ft}^{3} / \mathrm{s}$ (tables 12-15; fig. 22). The relatively large increases in estimated discharges between altitudes of 40 and $10 \mathrm{ft}$ mainly reflect ditch-return flows that enter Punaluu Stream between altitudes of about 35 and $15 \mathrm{ft}$. Estimated flow characteristics for LFPR stations at altitudes of 140, 100, 40 , and $10 \mathrm{ft}$ reflect recent diversion and return-flow practices for Punaluu Ditch.

\section{Flow Characteristics for Natural Conditions}

Flow characteristics for natural, undiverted conditions at the LFPR stations were estimated to determine the effects of the Punaluu Ditch diversion on streamflow at altitudes of 140 to $10 \mathrm{ft}$. Different methods were used to estimate natural-flow characteristics at the LFPR stations upstream and downstream from an altitude of $35 \mathrm{ft}$ because significant return flows from Punaluu Ditch enter the stream near an altitude of about 35 ft. Furthermore, ground water likely discharges to the main stream below an altitude of about $25 \mathrm{ft}$.

\section{Altitudes 140, 100, and 40 Feet}

For the LFPR station at an altitude of $140 \mathrm{ft}$, naturalflow characteristics were estimated from discharges measured at gaging station 16303003. For the MOVE.1 analysis, the differences in seven concurrent discharges (table 11) at an altitude of $140 \mathrm{ft}$ and at gaging station 16303000 range from 1 to 8 percent of the concurrent discharges at gaging station 16303003 , and average 4.2 percent. To estimate natural flowduration discharges at $140 \mathrm{ft}$, corresponding flow-duration discharges at gaging station 16303003 were multiplied by a constant factor of 1.042.

For the LFPR station at $100 \mathrm{ft}$, the average increase in discharge (from 11 concurrent measurements) between gaging station 16303000 and the LFPR station was 8.8 percent of the discharge at gaging station 16303003 . The increase in discharge between altitudes of $140 \mathrm{ft}$ (where discharge 
Table 8. Concurrent discharge values at the low-flow partial-record station at a stream altitude of 10 feet and at gaging stations 16303000 and 16303003, Punaluu Stream, Oahu, Hawaii.

[LFPR, low flow partial record; ft, feet; MOVE.1, maintenance of variance extension, type 1; --, not applicable]

\begin{tabular}{|c|c|c|c|c|c|}
\hline \multirow[b]{2}{*}{ Date } & \multirow[b]{2}{*}{ Time $^{1}$} & \multicolumn{3}{|c|}{ Discharge, in cubic feet per second } & \multirow[b]{2}{*}{ Remarks } \\
\hline & & $\begin{array}{l}\text { LFPR station, } \\
\text { altitude } 10 \mathrm{ft}\end{array}$ & $\begin{array}{c}\text { Gaging station } \\
16303000^{2} \\
\end{array}$ & $\begin{array}{c}\text { Gaging station } \\
16303003^{2}\end{array}$ & \\
\hline 07/09/2004 & 1037 & 29.2 & 16 & 28 & Flow receding \\
\hline 07/12/2004 & 1000 & 25.1 & 11 & 24 & Included in MOVE. 1 analysis \\
\hline 08/05/2004 & 1433 & 52.8 & 25 & 41 & Flow receding \\
\hline 08/06/2004 & 1219 & 39.0 & 19 & 33 & Flow receding \\
\hline $08 / 20 / 2004$ & 1045 & 25.5 & 14 & 22 & Included in MOVE. 1 analysis \\
\hline 09/10/2004 & 1034 & 22.6 & 13 & 20 & Included in MOVE. 1 analysis \\
\hline $10 / 07 / 2004$ & 0926 & 22.5 & 14 & 21 & Included in MOVE. 1 analysis \\
\hline $10 / 29 / 2004$ & 1145 & 31.7 & 19 & 29 & Flow receding \\
\hline $11 / 26 / 2004$ & 1205 & 56.9 & 44 & 46 & Flow receding \\
\hline $12 / 21 / 2004$ & 1121 & 22.2 & 12 & 20 & Included in MOVE. 1 analysis \\
\hline $12 / 28 / 2004$ & 1107 & 41.6 & 32 & 35 & Flow receding \\
\hline $12 / 30 / 2004$ & 0946 & 31.2 & 15 & 27 & Included in MOVE. 1 analysis \\
\hline $01 / 03 / 2005$ & 1219 & 33.9 & 27 & 29 & Included in MOVE. 1 analysis \\
\hline $01 / 11 / 2005$ & 1141 & 25.0 & 11 & 21 & Included in MOVE. 1 analysis \\
\hline $05 / 26 / 2005$ & 1555 & 19.7 & 7.0 & 18 & Included in MOVE. 1 analysis \\
\hline 06/09/2005 & 1651 & 16.5 & 11 & 17 & Included in MOVE. 1 analysis \\
\hline 06/22/2005 & 1117 & 21.0 & 8.6 & 20 & Included in MOVE. 1 analysis \\
\hline 08/04/2005 & 1550 & 15.3 & 10 & 18 & Included in MOVE. 1 analysis \\
\hline Mean $^{3}$ & -- & 1.358 & 1.083 & 1.325 & From logarithm of values \\
\hline $\begin{array}{l}\text { Standard } \\
\text { deviation }\end{array}$ & -- & 0.09962 & 0.1445 & 0.07003 & From logarithm of values \\
\hline
\end{tabular}

${ }^{1}$ Starting time of discharge measurement at the LFPR station.

${ }^{2}$ Discharges at gaging stations 16303000 and 16303003 are means for the 3-hour period prior to the starting time of the discharge measurement at the LFPR station.

${ }^{3}$ Mean and standard deviation of logarithm (base 10) of discharge values for dates used in MOVE.1 analysis. 
Table 9. Concurrent discharge values at the low-flow partial-record station at a stream altitude of 40 feet and at gaging stations 16303000 and 16303003, Punaluu Stream, Oahu, Hawaii.

[LFPR, low flow partial record; ft, feet; MOVE.1, maintenance of variance extension, type 1; --, not applicable]

\begin{tabular}{|c|c|c|c|c|c|}
\hline \multirow[b]{2}{*}{ Date } & \multirow[b]{2}{*}{ Time $^{1}$} & \multicolumn{3}{|c|}{ Discharge, in cubic feet per second } & \multirow[b]{2}{*}{ Remarks } \\
\hline & & $\begin{array}{l}\text { LFPR station, } \\
\text { altitude } 40 \mathrm{ft}\end{array}$ & $\begin{array}{c}\text { Gaging station } \\
16303000^{2}\end{array}$ & $\begin{array}{c}\text { Gaging station } \\
16303003^{2}\end{array}$ & \\
\hline $07 / 30 / 2004$ & 1324 & 13.1 & 7.1 & 21 & Included in MOVE. 1 analysis \\
\hline 08/06/2004 & 1553 & 31.3 & 18 & 31 & Flow receding \\
\hline 08/20/2004 & 1527 & 19.9 & 14 & 22 & Included in MOVE.1 analysis \\
\hline 09/10/2004 & 1006 & 17.4 & 13 & 20 & Included in MOVE.1 analysis \\
\hline 09/23/2004 & 1440 & 18.0 & 16 & 21 & Flow receding \\
\hline $10 / 07 / 2004$ & 1217 & 17.8 & 14 & 21 & Included in MOVE.1 analysis \\
\hline $10 / 29 / 2004$ & 1413 & 23.2 & 19 & 28 & Flow receding \\
\hline $11 / 26 / 2004$ & 1603 & 42.7 & 32 & 44 & Flow receding \\
\hline $12 / 29 / 2004$ & 1016 & 32.1 & 28 & 31 & Flow receding \\
\hline $12 / 30 / 2004$ & 1432 & 23.2 & 16 & 27 & Included in MOVE. 1 analysis \\
\hline $01 / 04 / 2005$ & 0943 & 29.4 & 26 & 27 & Included in MOVE.1 analysis \\
\hline $01 / 20 / 2005$ & 1003 & 21.4 & 21 & 24 & Included in MOVE.1 analysis \\
\hline $03 / 22 / 2005$ & 1614 & 14.9 & 8.1 & 20 & Included in MOVE.1 analysis \\
\hline 03/24/2005 & 1410 & 14.3 & 9.1 & 19 & Included in MOVE. 1 analysis \\
\hline 06/09/2005 & 1437 & 12.4 & 11 & 17 & Included in MOVE. 1 analysis \\
\hline $06 / 22 / 2005$ & 1415 & 10.7 & 8.6 & 20 & Included in MOVE. 1 analysis \\
\hline 08/04/2005 & 1338 & 10.3 & 10 & 18 & Included in MOVE.1 analysis \\
\hline Mean $^{3}$ & -- & 1.211 & 1.087 & 1.325 & From logarithm of values \\
\hline $\begin{array}{l}\text { Standard } \\
\text { deviation }\end{array}$ & -- & 0.1394 & 0.1708 & 0.06300 & From logarithm of values \\
\hline
\end{tabular}

${ }^{1}$ Starting time of discharge measurement at the LFPR station.

${ }^{2}$ Discharges at gaging stations 16303000 and 16303003 are means for the 3-hour period prior to the starting time of the discharge measurement at the LFPR station with the exception of the measurements of 07/30/2004 and 08/06/2004. For the measurements of 07/30/2004 and 08/06/2004, discharges at gaging stations 16303000 and 16303003 are from the 2-hour period prior to the starting time of the discharge measurement at the LFPR station.

${ }^{3}$ Mean and standard deviation of logarithm (base 10) of discharge values for dates used in MOVE.1 analysis. 
Table 10. Concurrent discharge values at the low-flow partial-record station at a stream altitude of 100 feet and at gaging stations 16303000 and 16303003, Punaluu Stream, Oahu, Hawaii.

[LFPR, low flow partial record; ft, feet; MOVE.1, maintenance of variance extension, type 1; --, not applicable]

\begin{tabular}{|c|c|c|c|c|c|}
\hline \multirow[b]{2}{*}{ Date } & \multirow[b]{2}{*}{ Time $^{1}$} & \multicolumn{3}{|c|}{ Discharge, in cubic feet per second } & \multirow[b]{2}{*}{ Remarks } \\
\hline & & $\begin{array}{l}\text { LFPR station, } \\
\text { altitude } 100 \mathrm{ft}\end{array}$ & $\begin{array}{l}\text { Gaging station } \\
16303000^{2}\end{array}$ & $\begin{array}{c}\text { Gaging station } \\
16303003^{2}\end{array}$ & \\
\hline 09/24/2004 & 1415 & 19.9 & 15 & 19 & Included in MOVE. 1 analysis \\
\hline $10 / 01 / 2004$ & 1020 & 11.7 & 9.1 & 19 & Included in MOVE. 1 analysis \\
\hline $11 / 02 / 2004$ & 0938 & 20.4 & 19 & 29 & Flow receding \\
\hline 03/22/2005 & 1431 & 11.0 & 8.0 & 20 & Included in MOVE. 1 analysis \\
\hline 04/14/2005 & 1735 & 11.8 & 8.6 & 21 & Included in MOVE. 1 analysis \\
\hline $04 / 26 / 2005$ & 1154 & 10.7 & 8.8 & 20 & Included in MOVE. 1 analysis \\
\hline 05/03/2005 & 1616 & 9.97 & 7.8 & 18 & Included in MOVE. 1 analysis \\
\hline $05 / 25 / 2005$ & 1213 & 14.3 & 10 & 18 & Ditch intake manipulated \\
\hline 06/09/2005 & 1050 & 12.1 & 11 & 17 & Included in MOVE. 1 analysis \\
\hline $06 / 16 / 2005$ & 1042 & 7.09 & 6.1 & 18 & Included in MOVE. 1 analysis \\
\hline $07 / 05 / 2005$ & 1155 & 18.0 & 21 & 21 & Included in MOVE. 1 analysis \\
\hline 08/01/2005 & 1540 & 4.58 & 3.0 & 16 & Included in MOVE. 1 analysis \\
\hline 08/04/2005 & 0955 & 9.56 & 10 & 18 & Included in MOVE. 1 analysis \\
\hline Mean $^{3}$ & -- & 1.031 & 0.9487 & 1.273 & From logarithm of values \\
\hline $\begin{array}{l}\text { Standard } \\
\text { deviation }^{3}\end{array}$ & -- & 0.1735 & 0.2138 & 0.03739 & From logarithm of values \\
\hline
\end{tabular}

${ }^{1}$ Starting time of discharge measurement at the LFPR station.

${ }^{2}$ Discharges at gaging stations 16303000 and 16303003 are from the 3-hour period prior to the starting time of the discharge measurement at the LFPR station with the exception of the measurement of 08/01/2005. For the measurement of 08/01/2005, discharges at gaging stations 16303000 and 16303003 are from the 1-hour period prior to the starting time of the discharge measurement at the LFPR station.

${ }^{3}$ Mean and standard deviation of logarithm (base 10) of discharge values for dates used in MOVE.1 analysis. 
Table 11. Concurrent discharge values at the low-flow partial-record station at a stream altitude of 140 feet and at gaging stations 16303000 and 16303003, Punaluu Stream, Oahu, Hawaii.

[LFPR, low flow partial record; ft, feet; MOVE.1, maintenance of variance extension, type 1; --, not applicable]

\begin{tabular}{|c|c|c|c|c|c|}
\hline \multirow[b]{2}{*}{ Date } & \multirow[b]{2}{*}{ Time $^{1}$} & \multicolumn{3}{|c|}{ Discharge, in cubic feet per second } & \multirow[b]{2}{*}{ Remarks } \\
\hline & & $\begin{array}{l}\text { LFPR station, } \\
\text { altitude } 140 \mathrm{ft}\end{array}$ & $\begin{array}{c}\text { Gaging station } \\
16303000^{2}\end{array}$ & $\begin{array}{l}\text { Gaging station } \\
16303003^{2}\end{array}$ & \\
\hline 09/24/2004 & 1118 & 15.2 & 15 & 20 & Included in MOVE. 1 analysis \\
\hline $10 / 01 / 2004$ & 1352 & 11.4 & 9.9 & 19 & Included in MOVE. 1 analysis \\
\hline $11 / 02 / 2004$ & 1431 & 17.0 & 19 & 28 & Flow receding \\
\hline 03/03/2005 & 1313 & 6.61 & 9.7 & 21 & Ditch intake cleared \\
\hline 03/22/2005 & 1037 & 8.62 & 7.5 & 20 & Included in MOVE. 1 analysis \\
\hline 04/14/2005 & 1510 & 9.67 & 8.5 & 21 & Included in MOVE. 1 analysis \\
\hline 05/17/2005 & 1330 & 4.12 & 3.8 & 17 & Included in MOVE. 1 analysis \\
\hline 05/25/2005 & 1209 & 12.6 & 10 & 18 & Ditch intake manipulated \\
\hline 06/09/2005 & 1100 & 11.9 & 11 & 17 & Included in MOVE. 1 analysis \\
\hline 08/01/2005 & 1554 & 3.46 & 3.1 & 16 & Included in MOVE. 1 analysis \\
\hline Mean $^{3}$ & -- & 0.9127 & 0.8698 & 1.267 & From logarithm of values \\
\hline $\begin{array}{l}\text { Standard } \\
\text { deviation }\end{array}$ & -- & 0.2428 & 0.2483 & 0.04496 & From logarithm of values \\
\hline
\end{tabular}

${ }^{1}$ Starting time of discharge measurement at the LFPR station.

${ }^{2}$ Discharges at gaging stations 16303000 and 16303003 are from the 3-hour period prior to the starting time of the discharge measurement at the LFPR station with the exception of the measurement of 08/01/2005. For the measurement of 08/01/2005, discharges at gaging stations 16303000 and 16303003 are from the 1-hour period prior to the starting time of the discharge measurement at the LFPR station.

${ }^{3}$ Mean and standard deviation of logarithm (base 10) of discharge values for dates used in MOVE.1 analysis. 
Table 12. Estimated flow-duration characteristics for natural and recent diverted conditions for the low-flow partial-record station at a stream altitude of 10 feet, Punaluu Stream, Oahu, Hawaii.

[LFPR, low flow partial record; $\mathrm{ft}$, feet; $\mathrm{ft}^{3} / \mathrm{s}$, cubic feet per second]

\begin{tabular}{|c|c|c|c|c|c|}
\hline \multirow[b]{2}{*}{$\begin{array}{l}\text { Percentage } \\
\text { of time flow } \\
\text { equaled or } \\
\text { exceeded }^{1}\end{array}$} & \multirow[b]{2}{*}{$\begin{array}{c}\text { Discharge at gaging } \\
\text { station } 16303000, \\
\text { in } \mathrm{ft}^{3} / \mathrm{s}\end{array}$} & \multirow[b]{2}{*}{$\begin{array}{c}\text { Discharge at gaging } \\
\text { station } 16303003 \\
\text { in } \mathrm{ft}^{3} / \mathrm{s}\end{array}$} & \multicolumn{2}{|c|}{ Diverted conditions } & \multirow{2}{*}{$\begin{array}{c}\text { Natural conditions } \\
\begin{array}{c}\text { Discharge at LFPR } \\
\text { station (altitude } 10 \\
\mathrm{ft} \text { ), in } \mathrm{ft}^{3} / \mathrm{s}\end{array}\end{array}$} \\
\hline & & & $\begin{array}{c}\text { Discharge at LFPR } \\
\text { station (altitude } 10 \\
\text { ft), in } \mathrm{ft}^{3} / \mathrm{s}\end{array}$ & $\begin{array}{l}\text { Standard } \\
\text { error, in } \\
\text { percent }\end{array}$ & \\
\hline 95 & 1.3 & 13 & 11 & 10 & 16 \\
\hline 90 & 2.1 & 14 & 13 & 9 & 17 \\
\hline 85 & 2.7 & 14 & 13 & 9 & 17 \\
\hline 80 & 3.4 & 15 & 14 & 7 & 18 \\
\hline 75 & 4.0 & 15 & 14 & 7 & 18 \\
\hline 70 & 4.5 & 16 & 15 & 6 & 19 \\
\hline 65 & 5.2 & 16 & 15 & 6 & 19 \\
\hline 60 & 5.7 & 17 & 17 & 5 & 21 \\
\hline 55 & 6.4 & 17 & 17 & 5 & 21 \\
\hline 50 & 7.0 & 18 & 18 & 4 & 22 \\
\hline 45 & 7.8 & 19 & 20 & 3 & 23 \\
\hline 40 & 8.6 & 19 & 20 & 3 & 23 \\
\hline 35 & 9.4 & 20 & 21 & 3 & 24 \\
\hline 30 & 11 & 21 & 23 & 3 & 25 \\
\hline 25 & 12 & 22 & 24 & 3 & 27 \\
\hline 20 & 13 & 24 & 27 & 5 & 29 \\
\hline
\end{tabular}

${ }^{1}$ Discharge values computed for the base period 1995-2004. 
Table 13. Estimated flow-duration characteristics for natural and recent diverted conditions for the low-flow partial-record station at a stream altitude of 40 feet, Punaluu Stream, Oahu, Hawaii.

[LFPR, low flow partial record; ft, feet; $\mathrm{ft}^{3} / \mathrm{s}$, cubic feet per second]

\begin{tabular}{|c|c|c|c|c|c|}
\hline \multirow[b]{2}{*}{$\begin{array}{l}\text { Percentage } \\
\text { of time flow } \\
\text { equaled or } \\
\text { exceeded }\end{array}$} & \multirow[b]{2}{*}{$\begin{array}{l}\text { Discharge at gaging } \\
\text { station } 16303000, \\
\text { in } \mathrm{ft}^{3} / \mathrm{s}\end{array}$} & \multirow[b]{2}{*}{$\begin{array}{c}\text { Discharge at gaging } \\
\text { station } 16303003 \\
\text { in } \mathrm{ft}^{3} / \mathrm{s}\end{array}$} & \multicolumn{2}{|c|}{ Diverted conditions } & \multirow{2}{*}{$\begin{array}{l}\text { Natural conditions } \\
\text { Discharge at LFPR } \\
\text { station (altitude } 40 \\
\mathrm{ft} \text { ), in } \mathrm{ft}^{3} / \mathrm{s}\end{array}$} \\
\hline & & & $\begin{array}{c}\text { Discharge at LFPR } \\
\text { station (altitude } 40 \\
\text { ft), in ft3 } 3 \text { s }\end{array}$ & $\begin{array}{l}\text { Standard } \\
\text { error, in } \\
\text { percent }\end{array}$ & \\
\hline 95 & 1.3 & 13 & 2.6 & 23 & 15 \\
\hline 90 & 2.1 & 14 & 3.9 & 18 & 17 \\
\hline 85 & 2.7 & 14 & 4.7 & 15 & 17 \\
\hline 80 & 3.4 & 15 & 5.7 & 12 & 18 \\
\hline 75 & 4.0 & 15 & 6.5 & 11 & 18 \\
\hline 70 & 4.5 & 16 & 7.2 & 9 & 19 \\
\hline 65 & 5.2 & 16 & 8.1 & 8 & 19 \\
\hline 60 & 5.7 & 17 & 8.7 & 7 & 20 \\
\hline 55 & 6.4 & 17 & 9.6 & 6 & 20 \\
\hline 50 & 7.0 & 18 & 10 & 6 & 21 \\
\hline 45 & 7.8 & 19 & 11 & 5 & 22 \\
\hline 40 & 8.6 & 19 & 12 & 5 & 22 \\
\hline 35 & 9.4 & 20 & 13 & 5 & 24 \\
\hline 30 & 11 & 21 & 15 & 6 & 25 \\
\hline 25 & 12 & 22 & 16 & 7 & 26 \\
\hline 20 & 13 & 24 & 17 & 7 & 28 \\
\hline
\end{tabular}

${ }^{1}$ Discharge values computed for the base period 1995-2004. 
Table 14. Estimated flow-duration characteristics for natural and recent diverted conditions for the low-flow partial-record station at a stream altitude of 100 feet, Punaluu Stream, Oahu, Hawaii.

[LFPR, low flow partial record; ft, feet; $\mathrm{ft}^{3} / \mathrm{s}$, cubic feet per second]

\begin{tabular}{|c|c|c|c|c|c|}
\hline \multirow[b]{2}{*}{$\begin{array}{l}\text { Percentage } \\
\text { of time flow } \\
\text { equaled or } \\
\text { exceeded }\end{array}$} & \multirow[b]{2}{*}{$\begin{array}{l}\text { Discharge at gaging } \\
\text { station } 16303000 \\
\text { in } \mathrm{ft}^{3} / \mathrm{s}\end{array}$} & \multirow[b]{2}{*}{$\begin{array}{c}\text { Discharge at gaging } \\
\text { station } 16303003 \\
\text { in } \mathrm{ft}^{3} / \mathrm{s}\end{array}$} & \multicolumn{2}{|c|}{ Diverted conditions } & \multirow{2}{*}{$\begin{array}{l}\text { Natural conditions } \\
\text { Discharge at LFPR } \\
\text { station (altitude } 100 \\
\mathrm{ft} \text { ), in } \mathrm{ft}^{3} / \mathrm{s}\end{array}$} \\
\hline & & & $\begin{array}{c}\text { Discharge at LFPR } \\
\text { station (altitude } 100 \\
\mathrm{ft} \text { ), in } \mathrm{ft}^{3} / \mathrm{s}\end{array}$ & $\begin{array}{l}\text { Standard } \\
\text { error, in } \\
\text { percent }\end{array}$ & \\
\hline 95 & 1.3 & 13 & 2.3 & 13 & 14 \\
\hline 90 & 2.1 & 14 & 3.3 & 10 & 15 \\
\hline 85 & 2.7 & 14 & 4.1 & 8 & 15 \\
\hline 80 & 3.4 & 15 & 4.9 & 7 & 16 \\
\hline 75 & 4.0 & 15 & 5.6 & 6 & 16 \\
\hline 70 & 4.5 & 16 & 6.2 & 5 & 17 \\
\hline 65 & 5.2 & 16 & 6.9 & 5 & 17 \\
\hline 60 & 5.7 & 17 & 7.5 & 5 & 18 \\
\hline 55 & 6.4 & 17 & 8.2 & 4 & 18 \\
\hline 50 & 7.0 & 18 & 8.8 & 4 & 20 \\
\hline 45 & 7.8 & 19 & 9.7 & 4 & 21 \\
\hline 40 & 8.6 & 19 & 10 & 5 & 21 \\
\hline 35 & 9.4 & 20 & 11 & 5 & 22 \\
\hline 30 & 11 & 21 & 13 & 5 & 23 \\
\hline 25 & 12 & 22 & 14 & 6 & 24 \\
\hline 20 & 13 & 24 & 15 & 6 & 26 \\
\hline
\end{tabular}

${ }^{1}$ Discharge values computed for the base period 1995-2004. 
Table 15. Estimated flow-duration characteristics for natural and recent diverted conditions for the low-flow partial-record station at a stream altitude of 140 feet, Punaluu Stream, Oahu, Hawaii.

[LFPR, low flow partial record; $\mathrm{ft}$, feet; $\mathrm{ft}^{3} / \mathrm{s}$, cubic feet per second]

\begin{tabular}{|c|c|c|c|c|c|}
\hline \multirow[b]{2}{*}{$\begin{array}{l}\text { Percentage } \\
\text { of time flow } \\
\text { equaled or } \\
\text { exceeded }\end{array}$} & \multirow[b]{2}{*}{$\begin{array}{c}\text { Discharge at gaging } \\
\text { station } 16303000, \\
\text { in } \mathrm{ft}^{3} / \mathrm{s}\end{array}$} & \multirow[b]{2}{*}{$\begin{array}{c}\text { Discharge at gaging } \\
\text { station } 16303003 \\
\text { in } \mathrm{ft}^{3} / \mathrm{s}\end{array}$} & \multicolumn{2}{|c|}{ Diverted conditions } & \multirow{2}{*}{$\begin{array}{c}\text { Natural conditions } \\
\text { Discharge at LFPR } \\
\text { station (altitude } 140 \\
\mathrm{ft} \text { ), in } \mathrm{ft}^{3} / \mathrm{s}\end{array}$} \\
\hline & & & $\begin{array}{c}\text { Discharge at LFPR } \\
\text { station (altitude } 140 \\
\mathrm{ft} \text { ), in } \mathrm{ft}^{3} / \mathrm{s}\end{array}$ & $\begin{array}{l}\text { Standard } \\
\text { error, in } \\
\text { percent }\end{array}$ & \\
\hline 95 & 1.3 & 13 & 1.5 & 7 & 14 \\
\hline 90 & 2.1 & 14 & 2.4 & 5 & 15 \\
\hline 85 & 2.7 & 14 & 3.0 & 4 & 15 \\
\hline 80 & 3.4 & 15 & 3.8 & 4 & 16 \\
\hline 75 & 4.0 & 15 & 4.5 & 3 & 16 \\
\hline 70 & 4.5 & 16 & 5.0 & 3 & 17 \\
\hline 65 & 5.2 & 16 & 5.8 & 3 & 17 \\
\hline 60 & 5.7 & 17 & 6.3 & 2 & 18 \\
\hline 55 & 6.4 & 17 & 7.1 & 2 & 18 \\
\hline 50 & 7.0 & 18 & 7.7 & 2 & 19 \\
\hline 45 & 7.8 & 19 & 8.6 & 2 & 20 \\
\hline 40 & 8.6 & 19 & 9.5 & 3 & 20 \\
\hline 35 & 9.4 & 20 & 10 & 3 & 21 \\
\hline 30 & 11 & 21 & 12 & 3 & 22 \\
\hline 25 & 12 & 22 & 13 & 3 & 23 \\
\hline 20 & 13 & 24 & 14 & 4 & 25 \\
\hline
\end{tabular}

${ }^{1}$ Discharge values computed for the base period 1995-2004. 

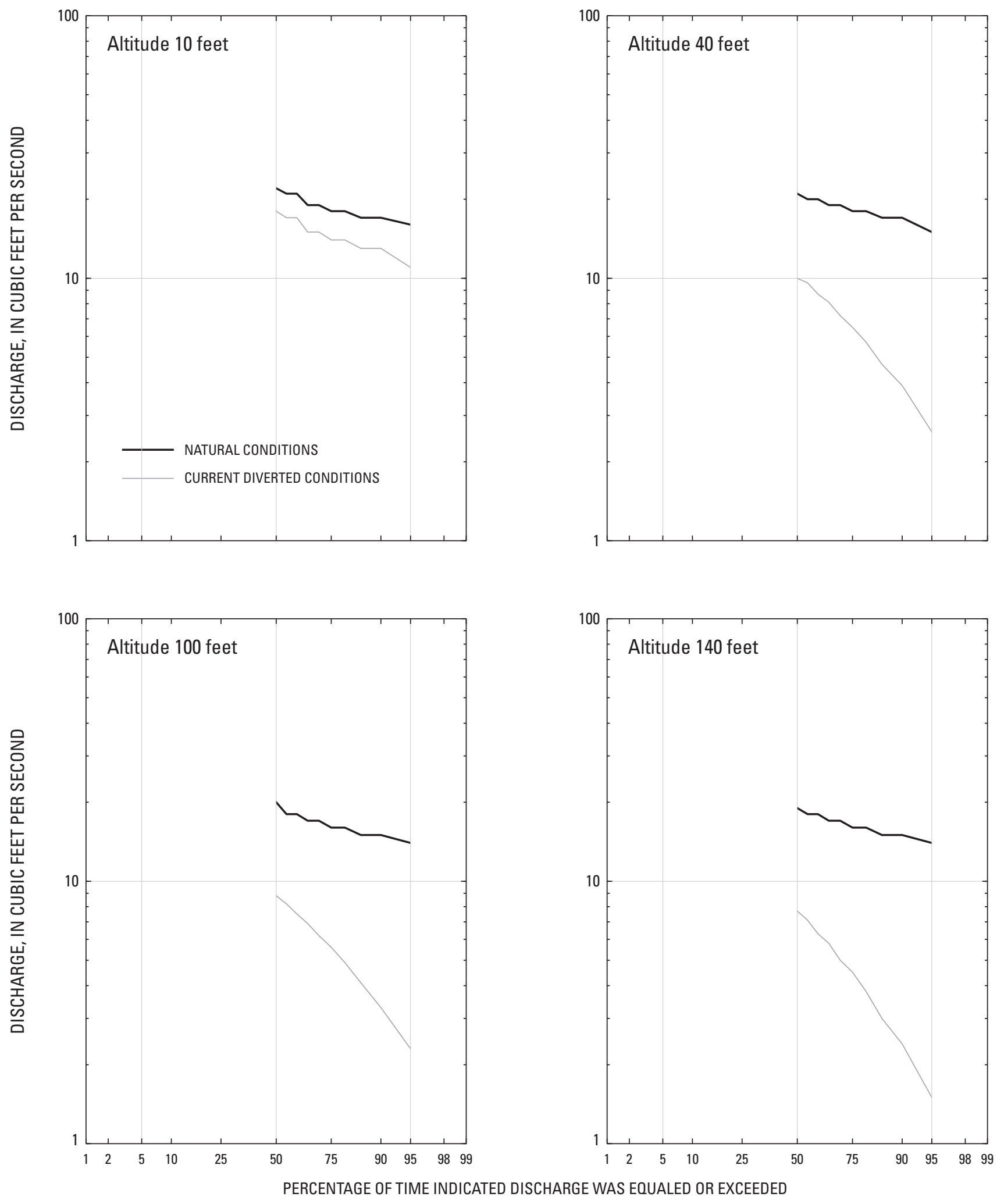

Figure 22. Flow-duration curves for low-flow partial-record stations at altitudes of 10, 40, 100, and 140 feet, Punaluu Stream, Oahu, Hawaii. 
is 4.2 percent higher than at gaging station 16303003) and $100 \mathrm{ft}$ (where discharge is 8.8 percent higher than at gaging station 16303003) reflects inflows from tributaries that enter the main stream between altitudes of $140 \mathrm{ft}$ and $100 \mathrm{ft}$. To estimate natural discharges at $100 \mathrm{ft}$, discharges at gaging station 16303003 were multiplied by a constant factor of 1.088 .

Similarly, for the LFPR station at $40 \mathrm{ft}$, the average increase in discharge (from 12 concurrent measurements) between gaging station 16303000 and the LFPR station was 18.2 percent of the discharge at gaging station 16303003 . To estimate natural discharges at $40 \mathrm{ft}$, discharges at gaging station 16303003 were multiplied by a constant factor of 1.182 .

Estimated median natural discharge at an altitude of $140 \mathrm{ft}$ is $19 \mathrm{ft}^{3} / \mathrm{s}$ (fig. 22). In comparison, the estimated median discharge for recent diverted conditions at that altitude is $7.7 \mathrm{ft}^{3} / \mathrm{s}$, or 41 percent of the median discharge for natural conditions (fig. 23). Estimated $\mathrm{Q}_{95}$ natural discharge at an altitude of $140 \mathrm{ft}$ is $14 \mathrm{ft}^{3} / \mathrm{s}$ (fig. 22). In comparison, the estimated $\mathrm{Q}_{95}$ flow for recent diverted conditions at that altitude is $1.5 \mathrm{ft}^{3} / \mathrm{s}$, which is about 11 percent of the estimated $Q_{95}$ natural discharge (fig. 23). Because the differences in concurrent discharges at an altitude of $140 \mathrm{ft}$ and at gaging station 16303000 were determined for periods when discharges at gaging station 16303003 were nearly equal to the 1995-2004 median discharge $\left(18 \mathrm{ft}^{3} / \mathrm{s}\right)$, the estimated natural flow-duration discharges at the LFPR station are most reliable for median-discharge conditions.
Estimated median natural discharge at an altitude of $100 \mathrm{ft}$ is $20 \mathrm{ft}^{3} / \mathrm{s}$ (fig. 22). In comparison, the estimated median discharge for recent diverted conditions at that altitude is $8.8 \mathrm{ft}^{3} / \mathrm{s}$, or 44 percent of the median discharge for natural conditions (fig. 23). Estimated $\mathrm{Q}_{95}$ natural discharge at an altitude of $100 \mathrm{ft}$ is $14 \mathrm{ft}^{3} / \mathrm{s}$ (fig. 22). In comparison, the estimated $\mathrm{Q}_{95}$ discharge for recent diverted conditions at that altitude is $2.3 \mathrm{ft}^{3} / \mathrm{s}$, or 16 percent of the estimated $\mathrm{Q}_{95}$ natural discharge (fig. 23).

Estimated median natural discharge at an altitude of $40 \mathrm{ft}$ is $21 \mathrm{ft}^{3} / \mathrm{s}$ (fig. 22). In comparison, the estimated median discharge for recent diverted conditions at that altitude is $10 \mathrm{ft}^{3} / \mathrm{s}$, or 48 percent of the median discharge for natural conditions (fig. 23). Estimated $Q_{95}$ natural discharge at an altitude of $40 \mathrm{ft}$ is $15 \mathrm{ft}^{3} / \mathrm{s}$ (fig. 22). In comparison, the estimated $\mathrm{Q}_{95}$ discharge for recent diverted conditions at that altitude is $2.6 \mathrm{ft}^{3} / \mathrm{s}$, or 17 percent of the estimated $\mathrm{Q}_{95}$ natural discharge (fig. 23).

\section{Altitude 10 Feet}

For the LFPR station at an altitude of $10 \mathrm{ft}$, natural flow-duration discharges were estimated as being equal to natural flow-duration discharges at the upstream LFPR station (altitude of $40 \mathrm{ft}$ ) plus gain estimated as a constant percentage of discharge at gaging station 16303003. On the basis of seepage-run measurements from September 10, 2004 and August 4, 2005, Punaluu Stream, respectively, gained 0.85

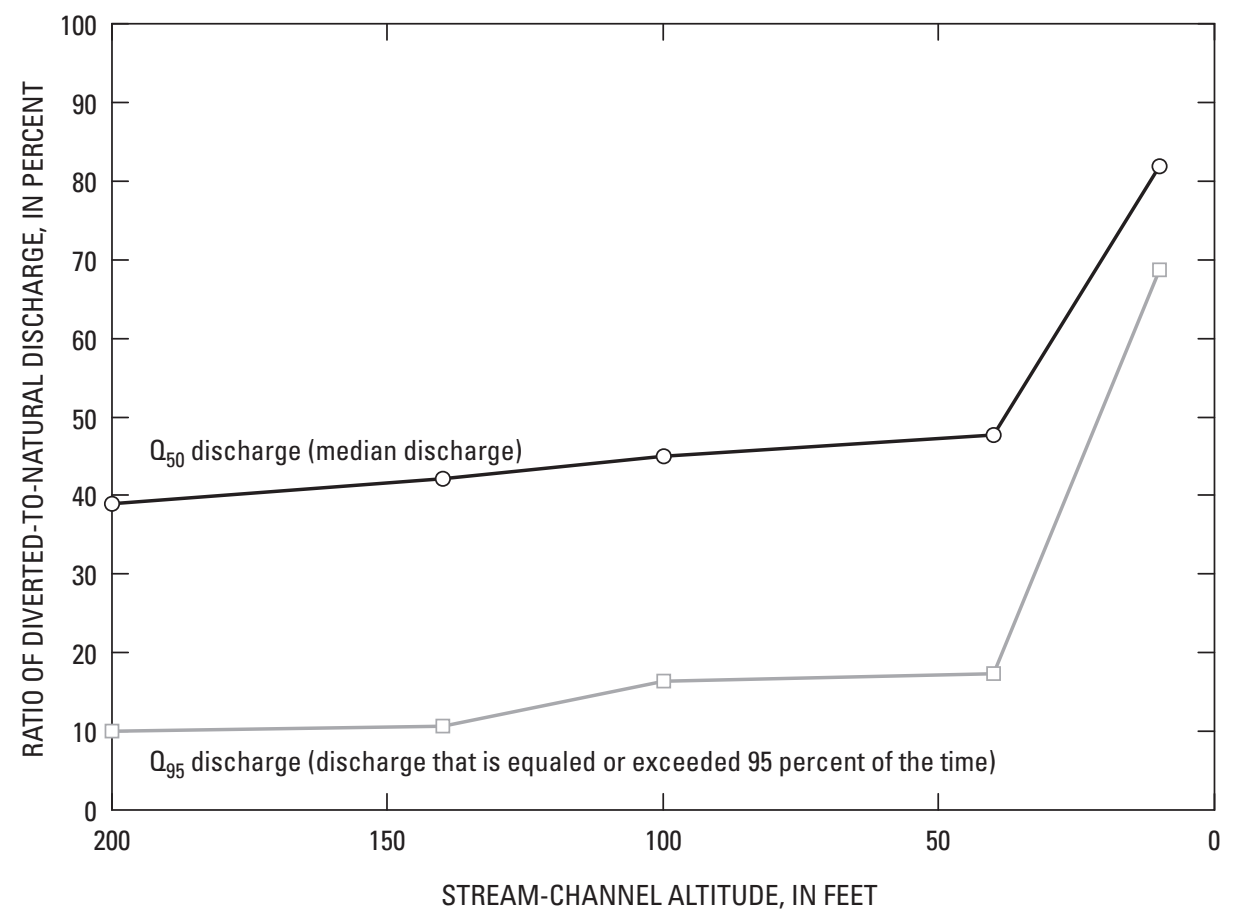

Figure 23. Ratios of diverted-to-natural discharges $\left(\mathrm{O}_{50}\right.$ and $\left.\mathrm{O}_{95}\right)$ at stream-channel altitudes of 10 to 200 feet, Punaluu Stream, Oahu, Hawaii. The $0_{50}$ discharge is the median discharge, and the $\mathrm{O}_{95}$ discharge is the discharge that is equaled or exceed 95 percent of the time. 
and $0.14 \mathrm{ft}^{3} / \mathrm{s}$ between the LFPR stations at altitudes of 40 and $10 \mathrm{ft}$ (fig. 16). Gains of 0.85 and $0.14 \mathrm{ft}^{3} / \mathrm{s}$ represent, respectively, 4.2 and 0.8 percent of the discharge at gaging station 16303003 on these 2 days. The average gain between the LFPR stations is 2.5 percent of the discharge at gaging station 16303003. The seepage-run measurements were made during periods corresponding to median- to $\mathrm{Q}_{35}$-discharge conditions at gaging station 16303003.

Estimated median natural discharge at an altitude of $10 \mathrm{ft}$ is $22 \mathrm{ft}^{3} / \mathrm{s}$ (fig. 22). In comparison, the estimated median discharge for recent diverted conditions at that altitude is $18 \mathrm{ft}^{3} / \mathrm{s}$, or 82 percent of the median discharge for natural conditions (fig. 23). Estimated $\mathrm{Q}_{95}$ natural discharge at an altitude of $10 \mathrm{ft}$ is $16 \mathrm{ft}^{3} / \mathrm{s}$ (fig. 22). In comparison, the estimated $\mathrm{Q}_{95}$ discharge for recent diverted conditions at that altitude is $11 \mathrm{ft}^{3} / \mathrm{s}$, or 69 percent of the estimated $Q_{95}$ natural discharge (fig. 23).

On the basis of estimated flow characteristics for recent diverted conditions and natural conditions, the effects of diversion on streamflow characteristics (for example $\mathrm{Q}_{50}$ and $\mathrm{Q}_{95}$ ) are largest immediately downstream from the diversion intake near an altitude of $210 \mathrm{ft}$ and decrease in a downstream direction (fig. 23). The effects of diversion are somewhat offset in a downstream direction by streamflow increases from tributaries, ditch return flows, and ground-water discharge. Diversion of water from Punaluu Stream will have an effect on habitat availability, although the effects are not expected to be as great as in streams from which all of the base flow is diverted and reaches are dry.

\section{Effects of Surface-Water Diversion on Habitat}

Changes in streamflow may affect the quantity and quality of physical habitat used by native stream fauna (Gingerich and Wolff, 2005). This section addresses the effects that streamflow reduction, caused by diverting water at the main Punaluu Ditch intake, will have on physical habitat in Punaluu Stream. Ground-water withdrawals that affect streamflow also can affect physical habitat used by the native fauna, although the spatial distributions of effects on physical habitat caused by the Punaluu Ditch diversion and ground-water withdrawals may differ. However, determination of the effects of groundwater withdrawal on physical habitat used by the native fauna was beyond the scope of this study.

The Instream Flow Incremental Methodology (IFIM) is a tool used to quantify the effects of incremental changes in streamflow, and was developed to assess instream flow issues and assist in water-management decisions (Bovee, 1982). The development of many small hydropower projects and expanding urban development encroaching on river and stream systems in the United States during the 1970s and 1980s led to the design and refinement of tools that evaluate instream-habitat quality and predict how the populations and communities of fish inhabiting the streams and rivers would be affected.
A number of these tools are referred to as habitat-selection models, preference models, or habitat-index models. The Physical Habitat Simulation System (PHABSIM) (Bovee, 1986; Bovee, 1997; Bovee and others, 1998) is an example of a habitat-selection model for stream organisms and has been used in many studies to assist in management decisions (Railsback and others, 2003). In Hawaii, Gingerich and Wolff (2005) used PHABSIM to evaluate the effects of surface-water diversions on streams in northeast Maui.

Habitat-selection modeling combines biological and hydrological components that may be related to the population of an aquatic species. Elements of the biological component usually include quantifying the frequency of microhabitat utilization of a target species. This is often compared with a measurement of microhabitat availability to define preference or habitat-suitability criteria. The preferred microhabitat is assumed to be the most advantageous for a specific activity and life stage of the target species. The hydrological component includes determination of streamflow characteristics and stream geomorphology. Computer models like PHABSIM are used to merge these components to estimate the quantity of preferred microhabitat area available for the target species with incremental changes in streamflow.

For this study, the effects of changes in streamflow on physical habitat in Punaluu Stream were evaluated using the PHABSIM approach. Measurements of microhabitat under different flow conditions in Punaluu Stream were combined with habitat-suitability criteria developed for streams in northeast Maui (Gingerich and Wolff, 2005). Habitat-suitability criteria developed for northeast Maui streams are transferable, in some cases, to other areas of the State (Gingerich and Wolff, 2005). Habitat-suitability criteria specific to Punaluu Stream were not developed for this study because existing populations of native species within the study reaches were considered too small for development of site-specific criteria.

\section{Stream Habitat Data Collection}

Habitat data were collected at four study reaches in Punaluu Stream. Study reaches, each about $300 \mathrm{ft}$ in length, were located at stream altitudes of 10, 40, 100, and $200 \mathrm{ft}$. In each reach, measurements of microhabitat characteristics (depth, velocity, and substrate) were made at 10 cross sections for 3 different flow conditions.

\section{Study Reaches}

Study reaches were selected on the basis of hydrologic, ecologic, access, and safety considerations. The boundaries of each 300-ft study reach were selected so that the reach was representative of the larger stream segment, in terms of flow regimes (riffles, runs, and pools) and substrate, and did not include any tributaries or diversions. All reaches are downstream from the Punaluu Ditch diversion intake near an altitude of $210 \mathrm{ft}$. Reaches upstream from the diversion intake 
were not studied because these reaches are in a natural condition unaffected by the diversion. Average stream-channel gradients in the selected reaches range from 0.3 to 4 percent, and increase in an upstream direction.

The lowermost reach, at an altitude of $10 \mathrm{ft}$, is located in an area that was straightened for flood control in 1988 by Koolau Agricultural Co., Ltd. (State of Hawaii, 1988). The stream subsequently was modified in 1991 in an attempt to restore the stream to its original meandering configuration. The lowermost reach is downstream from sites where water is returned to the stream from overflowing release gates along Punaluu Ditch (upstream from tunnel 12) and from irrigation-return water associated with taro cultivation. The average channel gradient is about 0.3 percent. Median discharge for recent diverted conditions in the reach is estimated to be about $18 \mathrm{ft}^{3} / \mathrm{s}$, whereas median natural discharge is estimated to be $22 \mathrm{ft}^{3} / \mathrm{s}$.

The reach at an altitude of $40 \mathrm{ft}$ is about midway between the Punaluu Ditch diversion intake and the coast, and is upstream from the main return flows to Punaluu Stream. This reach has an average channel gradient of about 0.9 percent. Median discharge for recent diverted conditions in the reach is estimated to be about $10 \mathrm{ft}^{3} / \mathrm{s}$, whereas median natural discharge is estimated to be $21 \mathrm{ft}^{3} / \mathrm{s}$.

The reach at an altitude of $100 \mathrm{ft}$ is about midway between the Punaluu Ditch diversion intake and the reach at an altitude of $40 \mathrm{ft}$. This reach has an average channel gradient of about 3 percent. Recent median discharge in the reach is estimated to be about $8.8 \mathrm{ft}^{3} / \mathrm{s}$, whereas median natural discharge is estimated to be $20 \mathrm{ft}^{3} / \mathrm{s}$.

The reach at an altitude of $200 \mathrm{ft}$ begins about $400 \mathrm{ft}$ downstream from the diversion intake. This reach has an average channel gradient of about 4 percent. Median diverted discharge in the reach is $7.0 \mathrm{ft}^{3} / \mathrm{s}$ based on data from gaging station 16303000 for water years 1995-2004. Median natural discharge in the reach is $18 \mathrm{ft}^{3} / \mathrm{s}$, based on data from gaging station 16303003 for water years 1995-2004.

\section{Cross Sections}

Cross-section locations within each reach were determined using a stratified-random design. Study reaches were stratified at the level of three habitat types: riffle, run, and pool (table 16). Riffles were defined as stream sections with high gradient, and shallow, fast-moving turbulent water. Runs were defined as stream sections with moderate- to fast-flowing water with minimal turbulence. Pools were defined as low gradient, deeper stream sections with low water velocity. Within the reach, the length and location of each discrete riffle, run, and pool were determined. The individual lengths were summed by habitat type and the proportion of each habitat type within the reach was calculated. Ten cross sections were located within each reach. The number of cross sections per habitat type was calculated based on the proportion of the habitat type within the reach. Once it was determined how many cross sections per habitat type were to be established, the location of each cross section was determined using random numbers from a computer-generated random numbers table. Brightly colored vinyl flagging tape was labeled and placed on the stream bank to mark the location of each cross section. At each cross-section location, semi-permanent boundary markers also were established on each stream bank. These semi-permanent markers made it possible to reestablish the cross-sections at later times.

For the reach at an altitude of $200 \mathrm{ft}, 10$ cross sections originally were defined, but one of the markers for the uppermost pool section was lost during a large storm. Data from the remaining nine cross sections were used in the habitat modeling. For this reach, 20 percent of the total length was characterized as pool habitat. Because one of the two pool sections was not available on all microhabitat measurement dates, habitat from the remaining pool section was weighted by a factor of two to reflect the percentage of pool habitat in the reach and to account for the missing tenth cross section.

Information on microhabitat availability was recorded at each cross section. Each cross section was subdivided into rectangular cells $1 \mathrm{ft}$ wide and extending $1 \mathrm{ft}$ downstream and $1 \mathrm{ft}$ upstream from a line connecting the ends of the section. Thus, each 1-ft-wide cell represents an area of $2 \mathrm{ft}^{2}$. The habitat variables (depth, velocity, and substrate) were measured at each individual cell. Water depth was determined from the water surface to the stream bottom at the center of the cell. Measured water depths ranged from 0 to about $4 \mathrm{ft}$. In general, velocity was determined at the center of the cell at a depth (as measured from the water surface) of 0.6 times the total water-column depth, although in some cells where depths exceeded $1.5 \mathrm{ft}$, velocity was measured at 0.2 and 0.8 depths.

Table 16. Percentage of riffle, run, and pool habitat within selected study reaches, Punaluu Stream, Oahu, Hawaii.

\begin{tabular}{ccccc}
\hline & \multicolumn{4}{c}{ Percentage of habitat } \\
\cline { 2 - 5 } Altitude of stream reach, in feet & Riffle & Run & Pool & Total \\
\hline 10 & 20 & 80 & 0 & 100 \\
40 & 40 & 60 & 0 & 100 \\
100 & 50 & 50 & 0 & 100 \\
200 & 50 & 30 & 20 & 100 \\
\hline
\end{tabular}


The measurement depths were selected because they provide a representation of the mean velocity in the vertical at a site (Rantz and others, 1982). All velocities were measured with acoustic-Doppler velocity (ADV) meters. Measured water velocities ranged from zero in pool areas or near stream edges to more than $3 \mathrm{ft} / \mathrm{s}$ in fast-moving shallow areas. Substrate was determined as the percent bottom cover of each substrate category (table 17) within the cell. The percent of each cell that was not completely submerged was recorded where applicable.

\section{Quantification of Suitable Habitat}

For this study, suitable physical habitat at four reaches in Punaluu Stream was quantified using the PHABSIM approach (U.S. Geological Survey, 2001). Habitat-suitability criteria from Gingerich and Wolff (2005) were used to determine the effects of incremental changes in streamflow on physical habitat for selected native species. Species that potentially could be found at a stream altitude of $200 \mathrm{ft}$ include Neritina granosa (hihiwai), Atyoida bisulcata (opae kalaole), Awaous guamensis (oopu nakea), and Sicyopterus stimpsoni (oopu nopili). Species that potentially could be found at stream altitudes of $100 \mathrm{ft}$ and lower include $N$. granosa (hihiwai) and A. guamensis (oopu nakea). Eleotris sandwicensis (oopu akupa) and Stenogobius hawaiiensis (oopu naniha) have been observed in Punaluu Stream below an altitude of $50 \mathrm{ft}$, but physical habitat for these species was not modeled because habitat-suitability criteria were neither available nor developed in this study. Habitat-suitability criteria for N. granosa (hihiwai) developed by Gingerich and Wolff (2005) were based on observations during daytime hours, although hihiwai apparently are more active during nighttime hours (Brasher, 1997).

Gingerich and Wolff (2005) determined suitable habitat with the PHABSIM model (U.S. Geological Survey, 2001), which does not accept suitability curves with step functions. For this study, suitable habitat was computed external to the PHABSIM model (using a digital spreadsheet), and the suitability curves (Gingerich and Wolff, 2005) were treated as step functions, which is consistent with the method used to develop the curves.

The habitat-suitability curves define weights, which may range in value from 0 (unusable habitat) to 1 (preferred habitat), for selected microhabitat parameters. For this study, the dominant substrate category (table 17) and dimensionless Froude number (fig. 24) were used to define microhabitat characteristics within each 1 -ft-wide cell of each cross section. The Froude number represents the ratio of inertia force to gravity force and is defined as:

$$
F=v /(d \mathrm{~g})^{1 / 2}
$$

where:

$\begin{array}{ll}F & \text { is the dimensionless Froude number, } \\ v & \text { is the water velocity }[\mathrm{L} / \mathrm{T}], \\ d & \text { is the water depth }[\mathrm{L}], \\ \mathrm{g} & \text { is the acceleration due to gravity }\left[\mathrm{L}^{2} \mathrm{~T}^{2}\right], \\ \mathrm{L} & \text { represents units of length, and } \\ \mathrm{T} & \text { represents units of time. }\end{array}$

If the Froude number is less than 1, flow is characterized as subcritical or tranquil, whereas if the Froude number is greater than 1, flow is supercritical, rapid, or shooting. A Froude number of 1 indicates critical flow (flow at minimum specific

Table 17. Substrate size categories and dominant substrate suitability values for selected native species (Gingerich and Wolff, 2005).

[--. Not applicable; >, greater than; in., inches]

\section{Dominant substrate suitability value}

\begin{tabular}{|c|c|c|c|c|c|c|c|}
\hline \multirow[b]{2}{*}{ Species } & \\
\hline & $\begin{array}{l}\text { Silt and } \\
\text { organic } \\
\text { detritus }\end{array}$ & $\begin{array}{c}\text { Sand } \\
(>0.002 \text { to } \\
0.08 \text { in. })\end{array}$ & $\begin{array}{c}\text { Gravel } \\
(>0.08 \text { to } 0.8 \\
\text { in. })\end{array}$ & $\begin{array}{c}\text { Cobble } \\
\text { (>0.8 to } 4 \text { in.) }\end{array}$ & $\begin{array}{c}\text { Small } \\
\text { boulder } \\
\text { (>4 to } 12 \text { in.) }\end{array}$ & $\begin{array}{l}\text { Large } \\
\text { boulder } \\
\text { (>12 in.) }\end{array}$ & $\begin{array}{c}\text { Bedrock or } \\
\text { compact } \\
\text { alluvium }\end{array}$ \\
\hline $\begin{array}{l}\text { Neritina granosa } \\
\quad \text { (hihiwai) }\end{array}$ & 0.2 & 0.2 & 0.2 & 0.5 & 0.5 & 1 & 0.2 \\
\hline $\begin{array}{l}\text { Atyoida bisulcata } \\
\text { (opae kalaole) }\end{array}$ & 0.2 & 0.2 & 0.2 & 0.2 & 0.5 & 1 & 0.2 \\
\hline $\begin{array}{l}\text { Awaous guamensis } \\
\quad \text { (oopu nakea), adult }\end{array}$ & 0.2 & 0.2 & 0.5 & 1 & 1 & 1 & 0.2 \\
\hline $\begin{array}{r}\text { Sicyopterus stimpsoni } \\
\text { (oopu nopili), adult }\end{array}$ & 0.2 & 0.2 & 0.2 & 1 & 1 & 1 & 0.2 \\
\hline $\begin{array}{l}\text { Sicyopterus stimpsoni } \\
\text { (oopu nopili), } \\
\text { juvenile }\end{array}$ & 0.2 & 0.2 & 0.2 & 0.5 & 1 & 1 & 0.2 \\
\hline
\end{tabular}



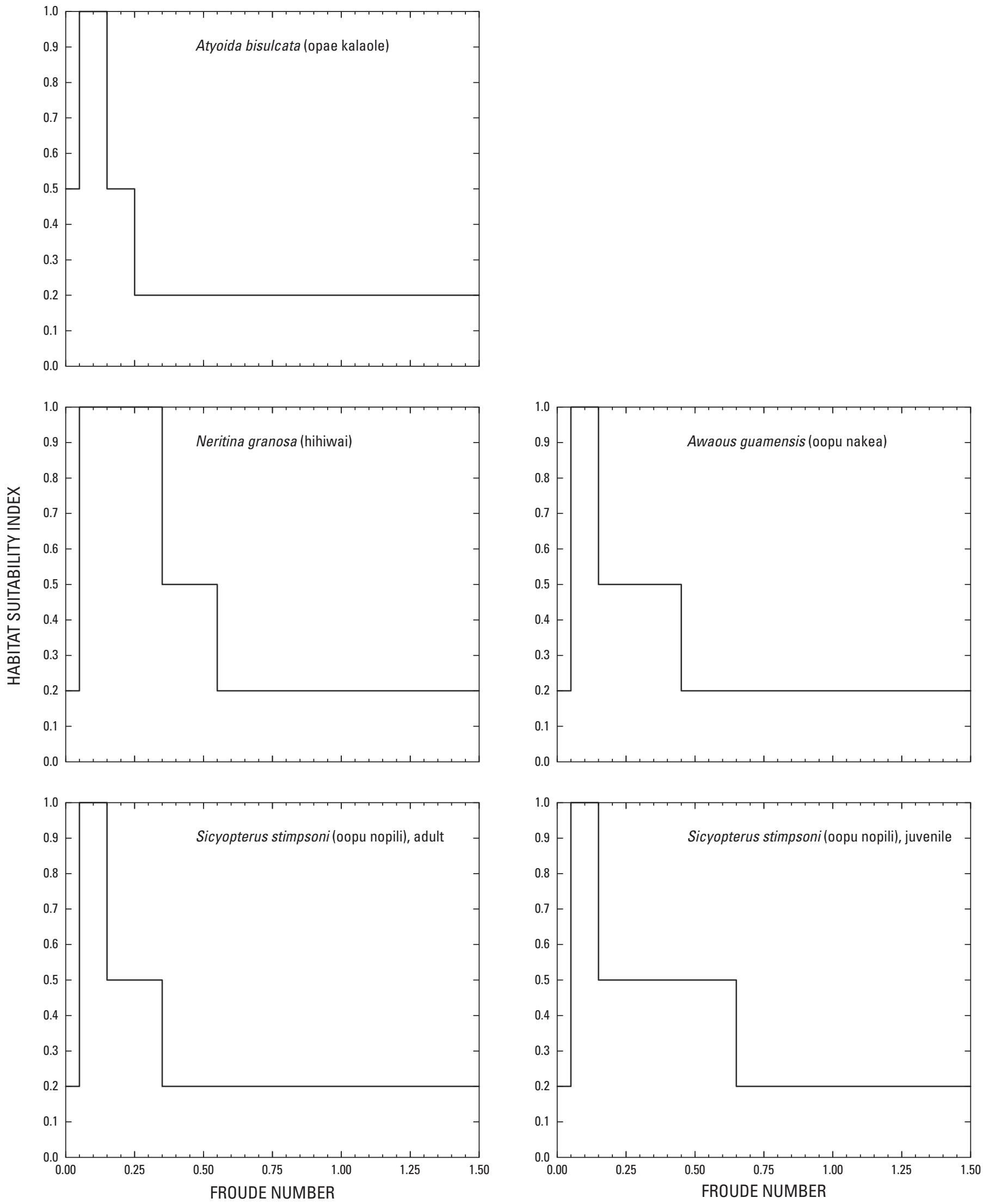

Figure 24. Habitat-suitability curves (Froude number) for selected native species, Hawaii (modified from Gingerich and Wolff, 2005). 
energy) (see for example Olson, 1980). Froude numbers computed from velocity and depth measurements in Punaluu Stream ranged from 0 in areas with standing water to about 1.5 in rapidly flowing riffle sections.

For each 1-ft-wide cell, a composite suitability was determined as:

$$
C_{\mathrm{i}}=F_{\mathrm{i}} \times S_{\mathrm{i}}
$$

where:

$C_{\mathrm{i}} \quad$ is the composite suitability of cell $\mathrm{i}$,

$F_{\mathrm{i}} \quad$ is the suitability associated with the Froude number in cell $\mathrm{i}$, and

$S_{\mathrm{i}} \quad$ is the suitability associated with the dominant substrate category in cell $i$.

The composite-suitability value may range from 0 (unusable habitat) to 1 (preferred habitat). The weighted usable area for a cell (wua), which is a measure of suitable physical habitat, is then computed from:

$$
w u a_{\mathrm{i}}=A_{\mathrm{i}} \times C_{\mathrm{i}} \times E_{\mathrm{i}}
$$

where:

$\begin{aligned} w u a_{\mathrm{i}} & \text { is the weighted usable area of cell } \mathrm{i}\left[\mathrm{L}^{2}\right], \\ A_{\mathrm{i}} & \text { is the area of cell } \mathrm{i}\left[\mathrm{L}^{2}\right], \\ C_{\mathrm{i}} & \text { is the composite suitability of cell } \mathrm{i} \text {, and } \\ E_{\mathrm{i}} & \text { is the fraction of cell } \mathrm{i} \text { that is submerged. }\end{aligned}$

For this study, each cell had a total area of $2 \mathrm{ft}^{2}$. The weighted usable area for each cross section was determined by adding the weighted-usable-area values for each cell in that cross section. Total weighted usable area (WUA) for the reach was then determined by summing the weighted-usablearea values for the 10 cross sections, which are representative of the reach. Because each 1-ft-wide cell in a cross section is $2 \mathrm{ft}$ long, the computed WUA value for a reach with 10 cross sections is expressed in terms of square feet per $20 \mathrm{ft}$ of stream length. By multiplying the WUA for the reach by a factor of 50, the WUA also can be expressed in terms of square feet per 1,000 ft of stream. Because a stratified-random design was used to select cross sections, riffles, runs, and pools were appropriately weighted according to availability in determining the WUA for each reach.

WUA was computed for each of the study reaches at each of three different measured discharge rates (figs. 25-28). For the reach at an altitude of $10 \mathrm{ft}$, microhabitat information was collected at discharge rates that were slightly greater than the estimated natural (undiverted) median discharge. For the reach at an altitude of $100 \mathrm{ft}$, microhabitat information was collected at discharge rates that were slightly less than the estimated natural (undiverted) median discharge. For the reaches at altitudes of 10 and $100 \mathrm{ft}$, WUA at the median natural discharge for the reach was estimated by linear extrapolation of the relation between WUA and discharge. For each study reach, estimates of WUA were needed for discharge rates lower than those measured to determine the shape of the relational curve between WUA and discharge. Linear interpolation of WUA between discharge rates of zero and the lowest measured discharge from the microhabitat surveys for a reach generally will result in an underestimation of WUA. Thus, for this study, WUA at low flows was estimated using elevation surveys of each cross section, measured stage-discharge relations for each cross section, and velocities that were estimated as a function of depth using Manning's formula and that were adjusted by a constant factor to produce the desired discharge (U.S. Geological Survey, 2001). Gingerich and Wolff (2005) used this approach to model WUA as a function of discharge in northeast Maui streams, where a wide range of discharges was not available. For this study, simulated WUA values at low discharge rates for a reach were scaled by the ratio of the measured-to-simulated WUA values at the lowest measured discharge rate. This scaling ensures that the simulated WUA will equal the measured value at the lowest measured discharge rate from the habitat surveys for a reach.

In general, the relations between WUA and discharge increase monotonically from a discharge of zero to the median natural discharge (figs. 25-28), although the relations for

Awaous guamensis for the reaches at altitudes of 10 and $40 \mathrm{ft}$ indicate a maximum WUA value at a discharge below the median natural discharge (figs. 25 and 26). At a stream altitude of $200 \mathrm{ft}$, the relations between WUA and discharge for all species generally are similar (fig. 28). The relations between WUA and discharge are steepest between discharge rates of zero and a few cubic feet per second, which indicates that the rate of increase in WUA is greatest as discharge increases from zero to a few cubic feet per second (and the rate of decrease in WUA is greatest as discharge decreases from a few cubic feet per second to zero). WUA values range from zero at no flow to more than $10,000 \mathrm{ft}^{2}$ per $1,000 \mathrm{ft}$ of stream for some species at flows below the median natural discharge.

\section{Habitat-Duration Characteristics}

A habitat-duration curve is similar to a flow-duration curve, but characterizes the percentage of time an indicated measure of habitat (rather than flow) is equaled or exceeded. For this study, the measure of habitat considered is WUA, expressed as a percentage of WUA at median natural discharge at the site. Because the relation between WUA and discharge generally was not characterized for discharges much higher than the natural median discharge, habitat-duration curves were developed for periods limited to when streamflow was less than or equal to the median discharge at the site. Thus, habitat-duration curves developed for this study reflect the percentage of time a specified weighted-usable-area value is equaled or exceeded during periods when streamflow at a site is less than or equal to the median discharge at the site (for the flow condition represented by the habitat-duration curve). The habitat-duration curves were developed for low-flow conditions (less than median discharge), representing 50 percent of the total time. Habitat-duration percentiles were adjusted, by 

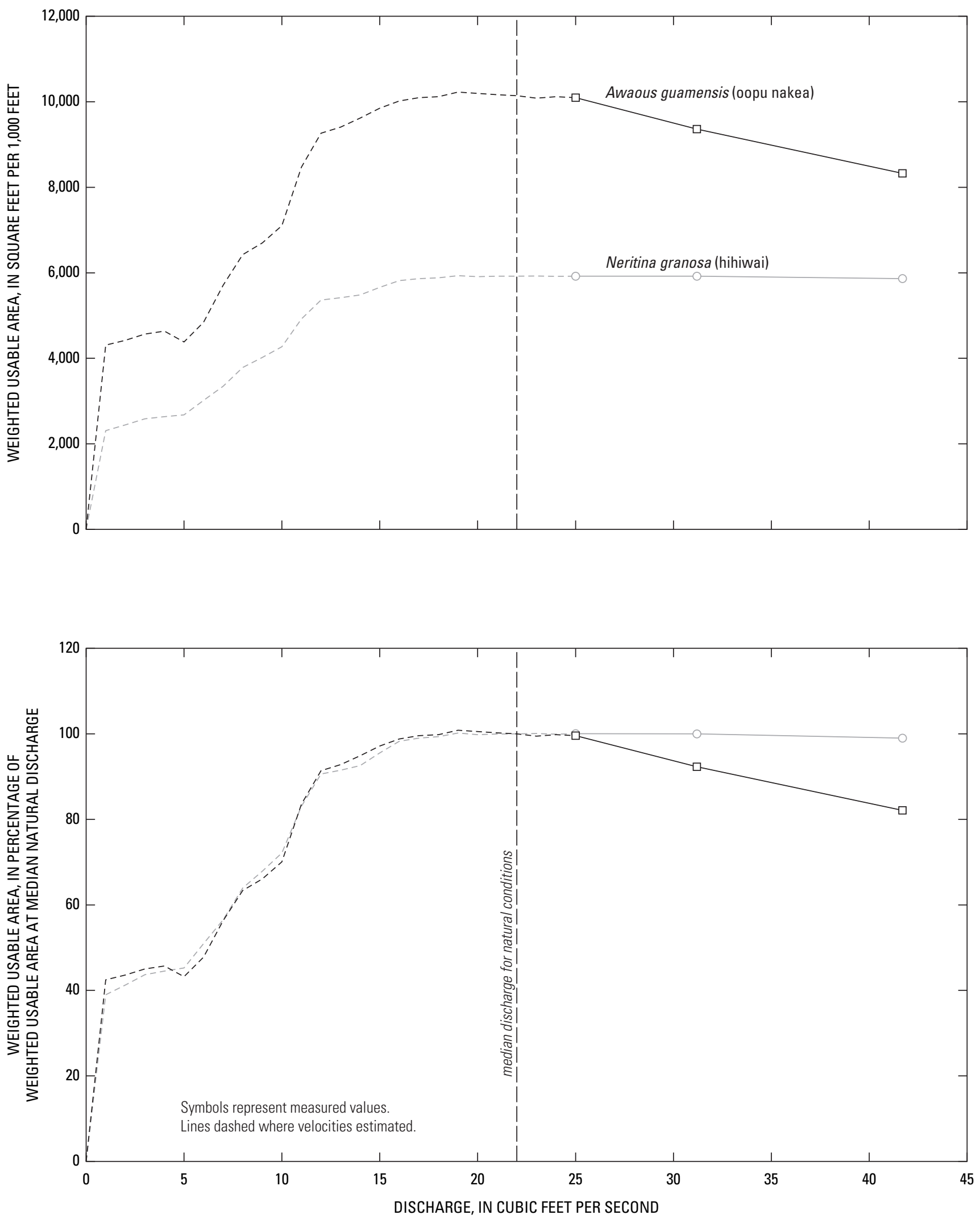

Figure 25. Relation between habitat (weighted usable area) for selected native species and discharge at an altitude of 10 feet (reach 1), Punaluu Stream, Oahu, Hawaii. 

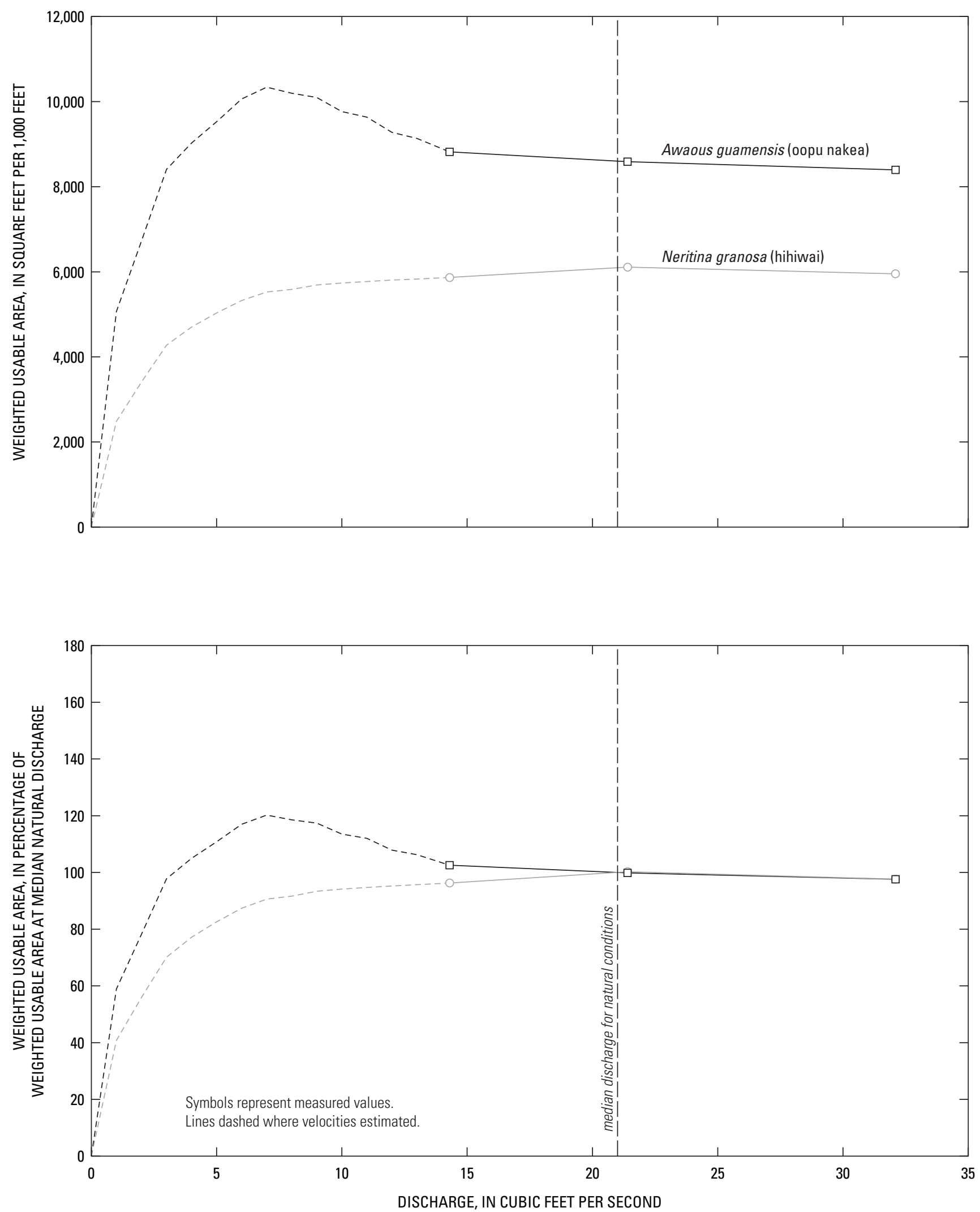

Figure 26. Relation between habitat (weighted usable area) for selected native species and discharge at an altitude of 40 feet (reach 2), Punaluu Stream, Oahu, Hawaii. 

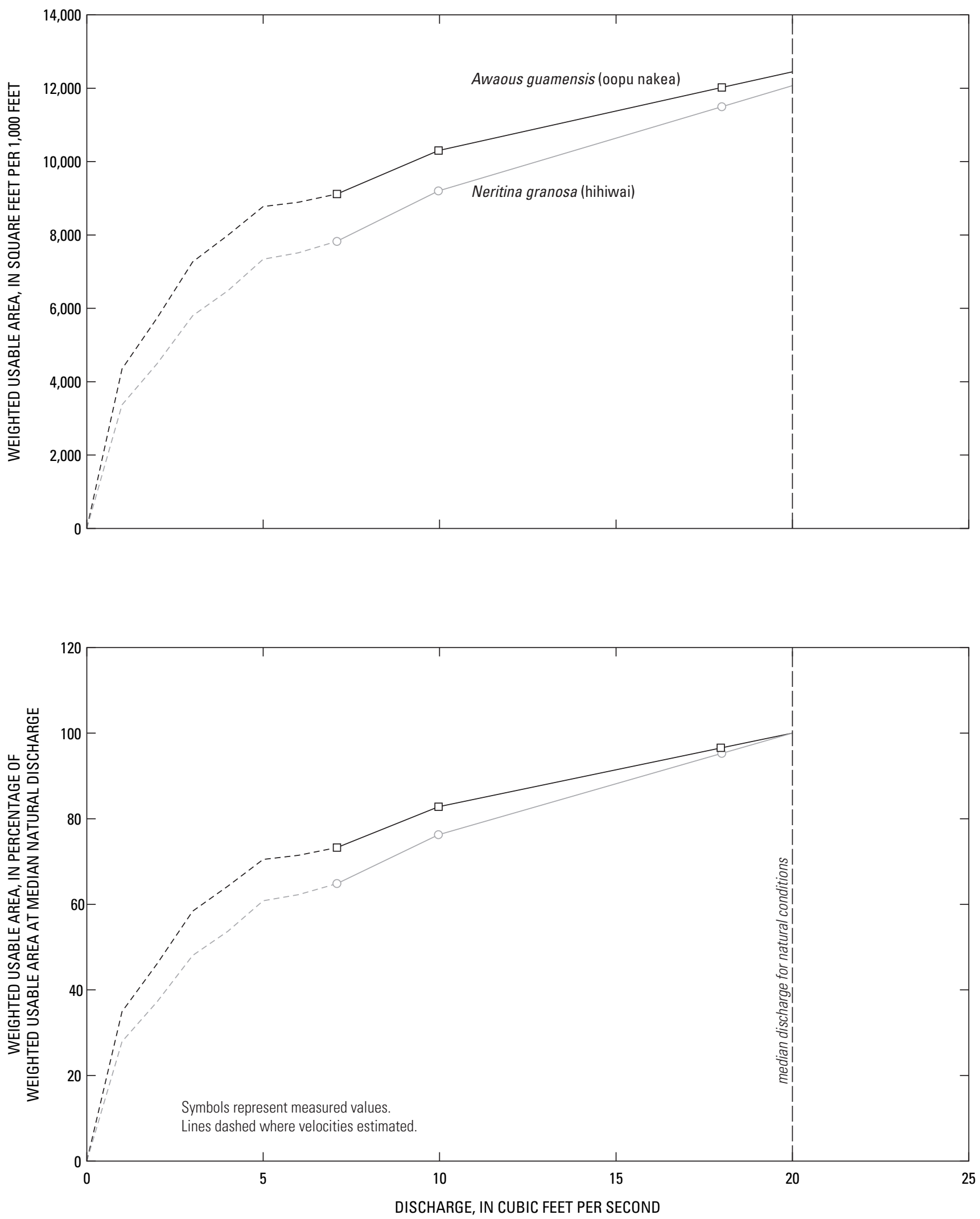

Figure 27. Relation between habitat (weighted usable area) for selected native species and discharge at an altitude of 100 feet (reach 2b), Punaluu Stream, Oahu, Hawaii. 

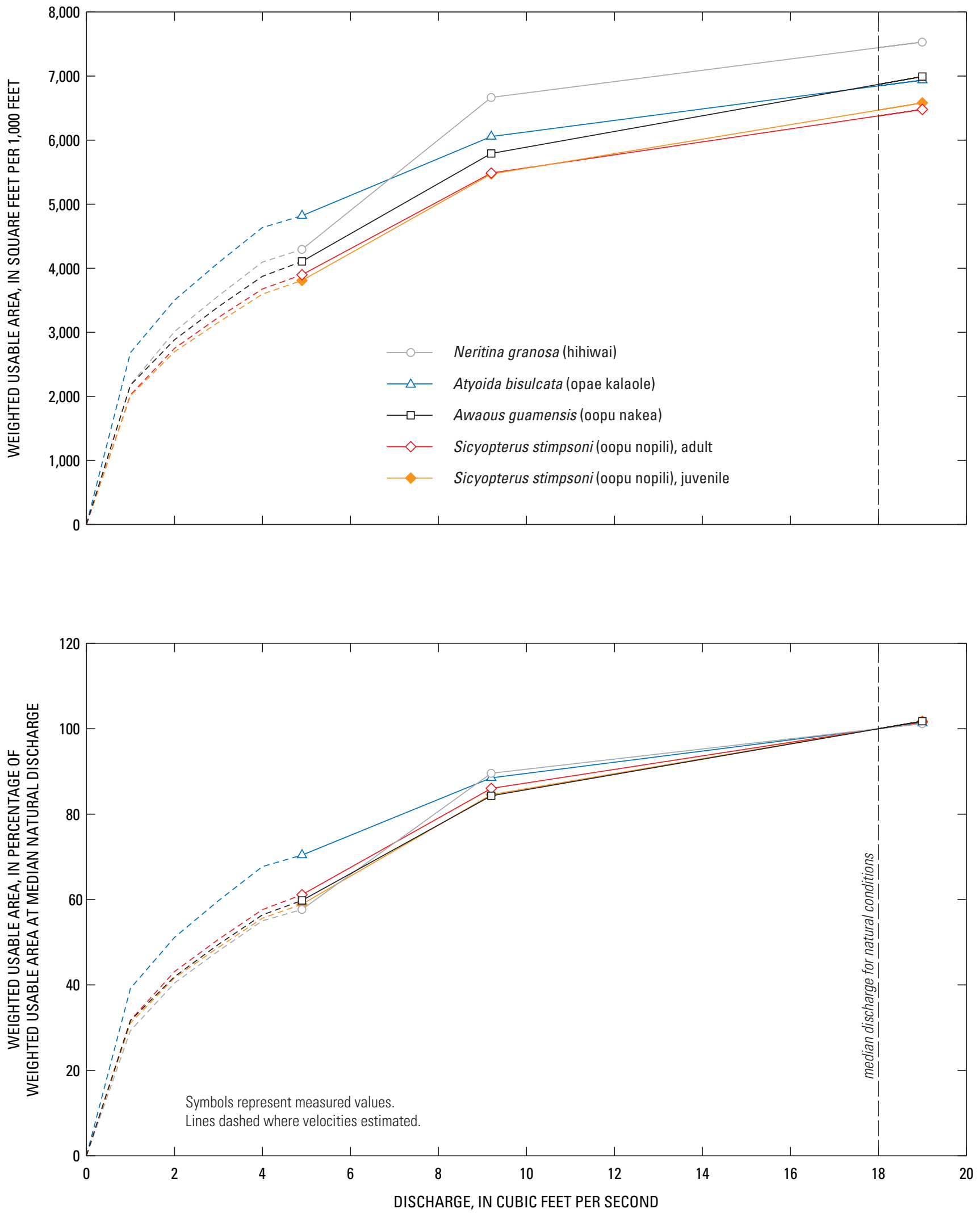

Figure 28. Relation between habitat (weighted usable area) for selected native species and discharge at an altitude of 200 feet (reach 3), Punaluu Stream, Oahu, Hawaii. 
doubling all values, to reflect 100 percent of the time during low-flow conditions.

Habitat-duration curves were developed for Neritina granosa (hihiwai) and Awaous guamensis (oopu nakea) at all four study reaches (altitudes of 10, 40, 100, and $200 \mathrm{ft}$ ) (figs. 29 and 30). For the study reach at an altitude of $200 \mathrm{ft}$, habitat-duration curves developed for Atyoida bisulcata (opae kalaole) and Sicyopterus stimpsoni (oopu nopili) (fig. 30) are similar to those for $N$. granosa and A. guamensis. Habitat-duration curves for $N$. granosa and A. guamensis were developed for four flow scenarios: (1) natural-flow conditions, (2) recent diverted-flow conditions, (3) constant diversion of $5 \mathrm{ft}^{3} / \mathrm{s}$, and (4) constant diversion of $10 \mathrm{ft}^{3} / \mathrm{s}$ (figs. 29 and 30). During water years 1995-2004, the mean diverted discharge at the Punaluu Ditch intake was $10.8 \mathrm{ft}^{3} / \mathrm{s}$, although the diversion rate was not constant. Comparisons of habitat-duration curves for the different flow scenarios indicate the effects of diversion on physical habitat for selected native species in Punaluu Stream.

Similar to flow-duration curves, flat habitat-duration curves indicate less variable habitat conditions than steeper habitat-duration curves. At stream altitudes of $40 \mathrm{ft}$ and higher, the habitat-duration curves (for a particular species) for recent diverted-flow conditions generally are steeper than the habitat-duration curves for the other three flow conditions, indicating greatest habitat variability for recent diverted-flow conditions (figs. 29 and 30). Because a substantial amount (several cubic feet per second) of diverted water is returned to Punaluu Stream between altitudes of about 15 and $35 \mathrm{ft}$, the habitat-duration curve for recent diverted-flow conditions at an altitude of $10 \mathrm{ft}$ is flatter than it would be if no water were returned to the stream above $10 \mathrm{ft}$.

To evaluate the effects of different rates of diversion on habitat, WUA values equaled or exceeded 50 percent of the time $\left(\mathrm{H}_{50}\right)$ and 90 percent of the time $\left(\mathrm{H}_{90}\right)$ (during periods when discharge is less than or equal to median discharge for the diversion condition) were determined for constant rates of diversion between 1 and $10 \mathrm{ft}^{3} / \mathrm{s}$. Habitat conditions that are equaled or exceeded 50 percent of the time $\left(\mathrm{H}_{50}\right)$ represent median-habitat conditions, and are analogous to median discharges $\left(\mathrm{Q}_{50}\right)$. For the 1 to $10 \mathrm{ft}^{3} / \mathrm{s}$ diversion scenarios, diversion of water from Punaluu Stream was assumed to be at the intake to Punaluu Ditch at an altitude of about $210 \mathrm{ft}$, with no return of diverted water to the stream. The relations between habitat and diversion rate were determined for stream altitudes of 10, 40, 100, and $200 \mathrm{ft}$ for both Neritina granosa (hihiwai) and Awaous guamensis (oopu nakea) (fig. 31 and 32). Because adult Atyoida bisulcata (opae kalaole) and Sicyopterus stimpsoni (oopu nopili) are not expected to populate the lower stream reaches, comparisons of the relations between habitat and diversion rate at different stream altitudes for these species were not made. On the basis of habitat-duration curves at a stream altitude of $200 \mathrm{ft}$ (fig. 30), the relations between habitat and diversion rate for A. bisulcata (opae kalaole) and S. stimpsoni (oopu nopili) are likely to be similar to those for N. granosa (hihiwai) and A. guamensis (oopu nakea) at that altitude.

\section{Neritina granosa (hihiwai)}

At stream altitudes of 10, 40, 100, and $200 \mathrm{ft}, \mathrm{H}_{50}$ and $\mathrm{H}_{90}$ values for Neritina granosa decrease with increasing diversion rates within the range of 1 to $10 \mathrm{ft}^{3} / \mathrm{s}$ (fig. 31). Results indicate that $\mathrm{H}_{90}$ values generally are affected to a relatively greater extent than $\mathrm{H}_{50}$ values by diversion of water from Punaluu Stream, particularly for higher diversion rates (fig. 31). At stream altitudes of $10,40,100$, and $200 \mathrm{ft}$, (1) $\mathrm{H}_{50}$ values are reduced by less than 14 percent, relative to the corresponding values for natural conditions, for constant diversion rates of 1 to $5 \mathrm{ft}^{3} / \mathrm{s}$; (2) $\mathrm{H}_{50}$ values are reduced by 7 to 40 percent for a constant diversion rate of $10 \mathrm{ft}^{3} / \mathrm{s}$; (3) $\mathrm{H}_{90}$ values are reduced by less than 16 percent, relative to the corresponding values for natural conditions, for constant diversion rates of 1 to $5 \mathrm{ft}^{3} / \mathrm{s}$; and (4) $\mathrm{H}_{90}$ values are reduced by 12 to 50 percent for a constant diversion rate of $10 \mathrm{ft}^{3} / \mathrm{s}$. At stream altitudes of 10 , 100 , and $200 \mathrm{ft}$ and for a constant diversion rate of $10 \mathrm{ft}^{3} / \mathrm{s}$, $\mathrm{H}_{50}$ values are reduced by 30 to 40 percent and $\mathrm{H}_{90}$ values are reduced by 36 to 50 percent relative to the corresponding values for natural conditions. For recent (1995-2004) diverted conditions, $\mathrm{H}_{50}$ and $\mathrm{H}_{90}$ values increase in a downstream direction, mainly in response to tributary inflows and ditch return flows.

The effects of different diversion conditions on WUA for Neritina granosa also may be described by the average number of days per year for which WUA values are less than a specified reference value (during periods when discharge is less than or equal to the median natural discharge) (fig. 33). For natural-flow conditions, WUA values are less than 75 percent of the WUA values at median natural discharge at stream altitudes of 10, 40,100, and $200 \mathrm{ft}$ for fewer than 3 days per year (on average). For recent diverted conditions, the average number of days per year that WUA values are less than 50 or 75 percent of the WUA value at median natural discharge generally (1) decreases in a downstream direction, reflecting the effects of tributary inflows and ditch return flows, (2) is less than the corresponding number of days for constant diversion rates greater than about $4-5 \mathrm{ft}^{3} / \mathrm{s}$ at a stream altitude of $10 \mathrm{ft}$, and (3) is greater than the corresponding number of days for a constant diversion rate of $10 \mathrm{ft}^{3} / \mathrm{s}$ at stream altitudes of 40 , 100 , and $140 \mathrm{ft}$.

At stream altitudes of 10, 40, 100, and $200 \mathrm{ft}$ and for constant diversion rates of up to $8 \mathrm{ft}^{3} / \mathrm{s}$, WUA values are less than 50 percent of the WUA value at median natural discharge for fewer than 4 days per year. At a stream altitude of $200 \mathrm{ft}$ and for a constant diversion rate of $10 \mathrm{ft}^{3} / \mathrm{s}$, WUA values are less than 50 percent of the WUA value at median natural discharge for about 30 days per year. At stream altitudes of 10, 40, 100, and $200 \mathrm{ft}$, WUA values are less than 75 percent of the WUA value at median natural discharge for fewer than 13 days per year for constant diversion rates of up to $4 \mathrm{ft}^{3} / \mathrm{s}$. At stream altitudes of 10,100, and $200 \mathrm{ft}$, (1) the average number of days 
Neritina granosa (hihiwai)
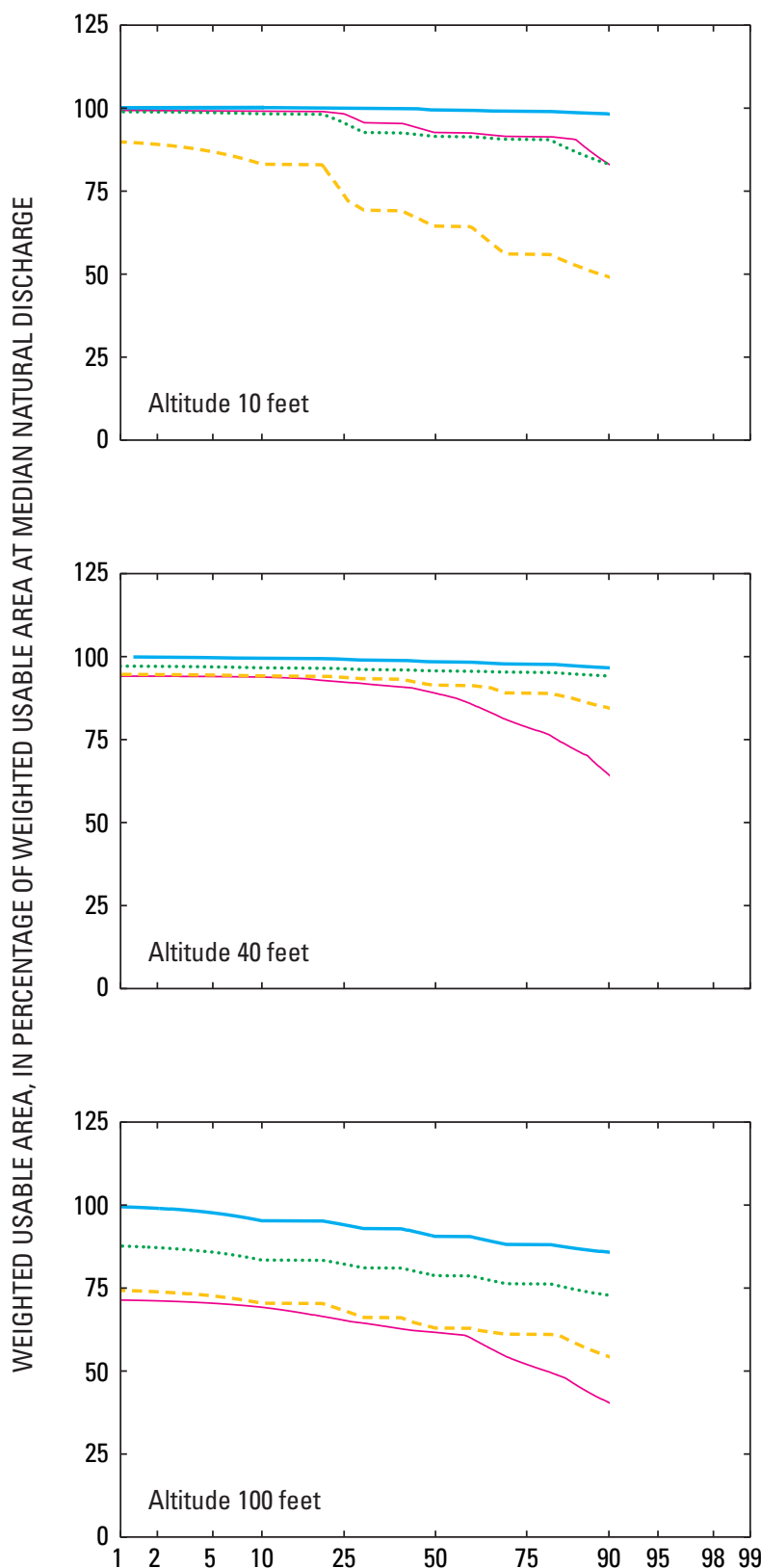

PERCENTAGE OF TIME (DURING PERIODS WHEN DISCHARGE WAS LESS THAN OR EOUAL TO THE MEDIAN DISCHARGE) INDICATED WEIGHTED-USABLE-AREA VALUE WAS EQUALED OR EXCEEDED

\section{EXPLANATION}

NATURAL-FLOW CONDITIONS

CONSTANT DIVERSION--

5 CUBIC FEET PER SECOND

CONSTANT DIVERSION--

10 CUBIC FEET PER SECOND

RECENT DIVERTED CONDITIONS
Awaous guamensis (oopu nakea)
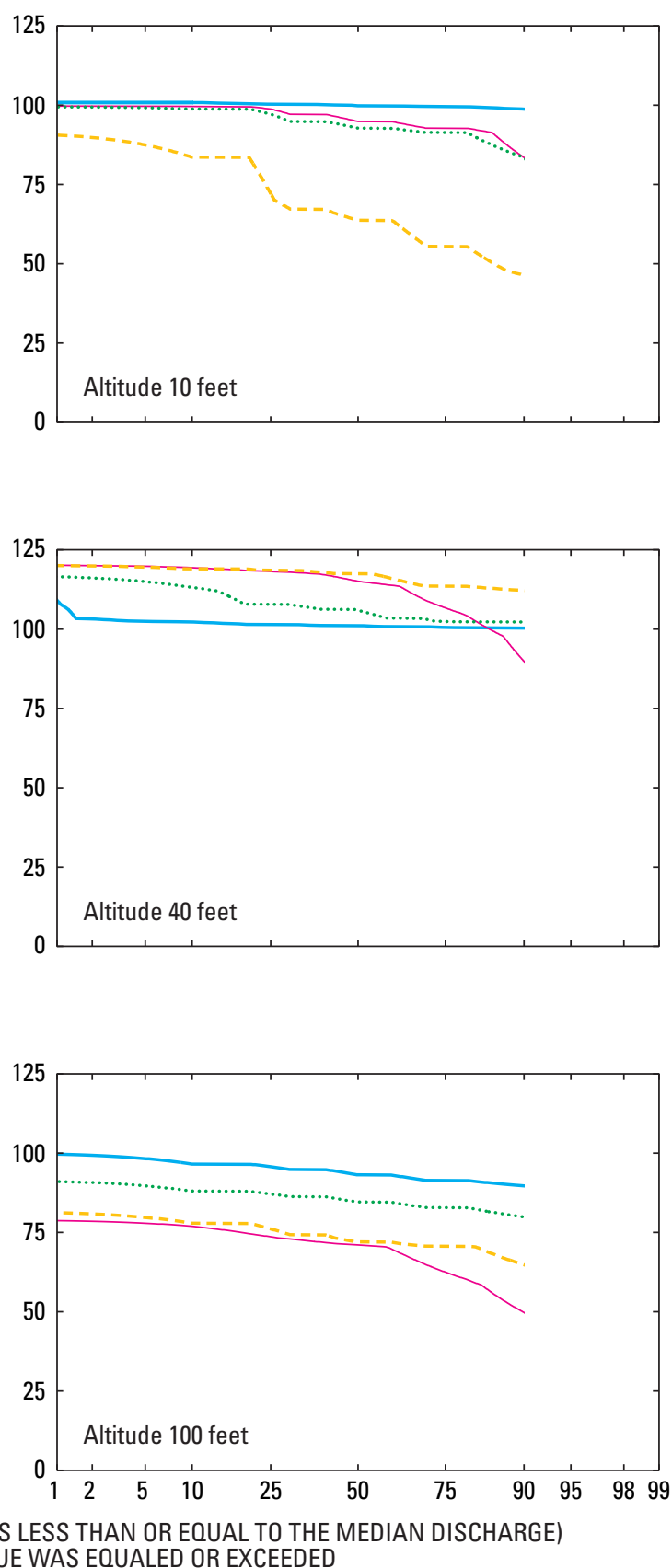


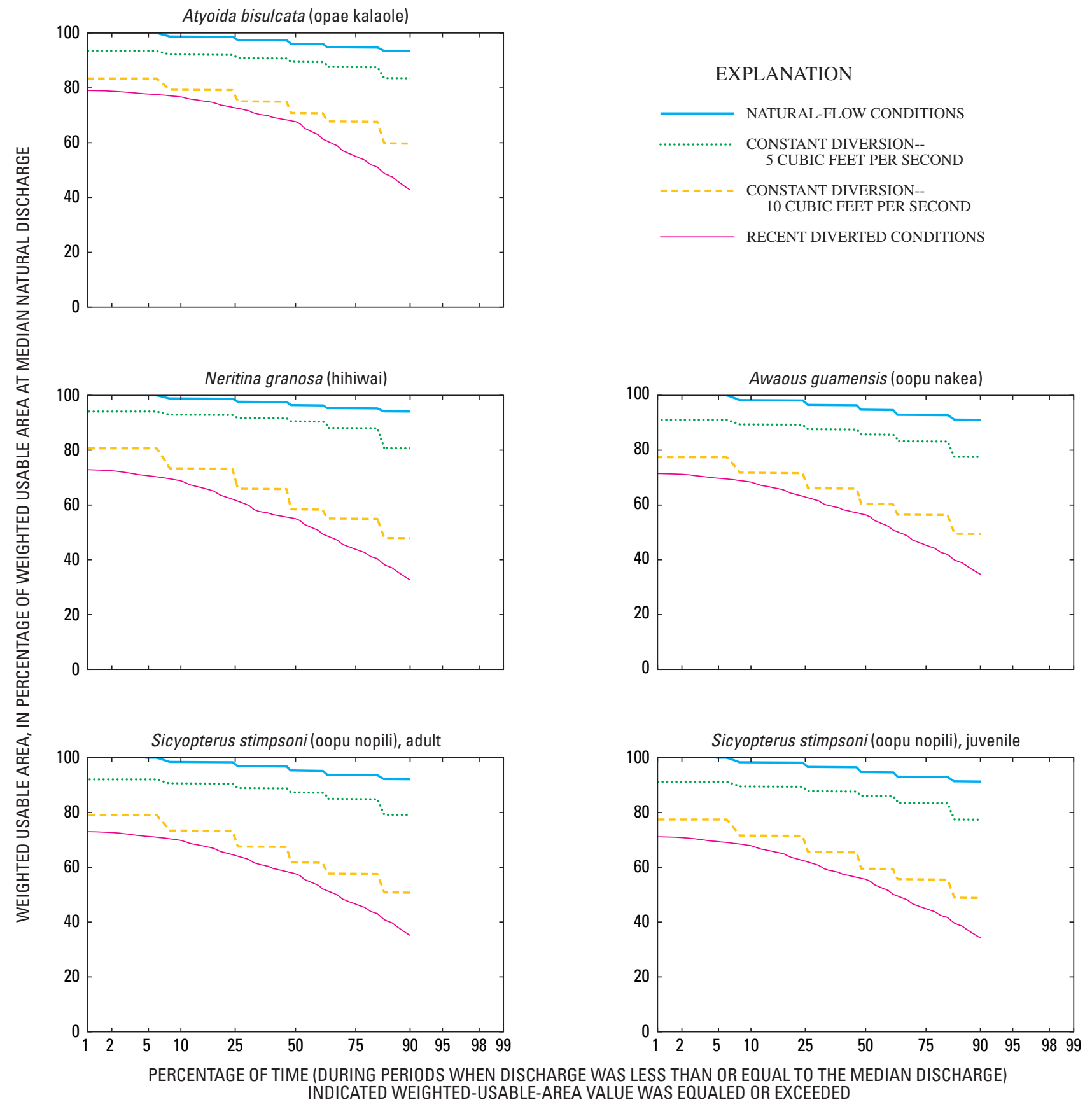

Figure 30. Habitat-duration curves for the study reach at an altitude of 200 feet, Punaluu Stream, Oahu, Hawaii. 


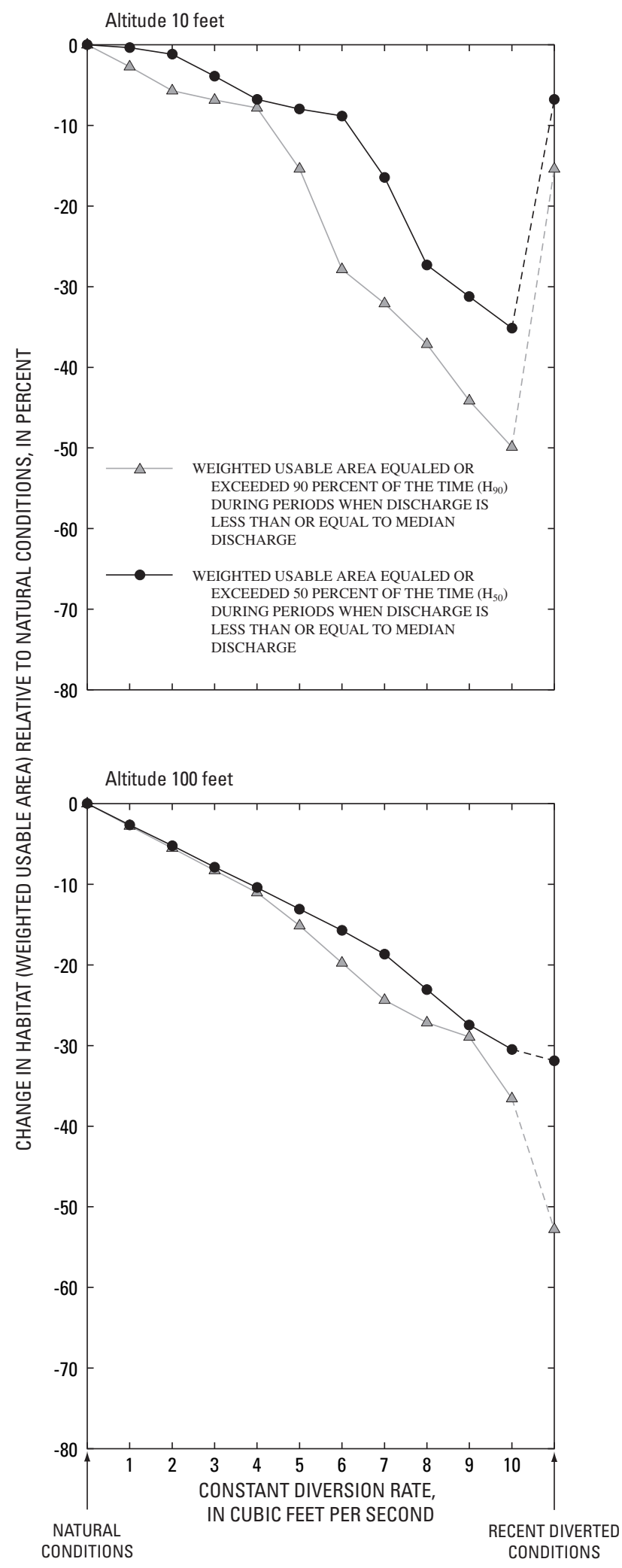

Altitude 40 feet

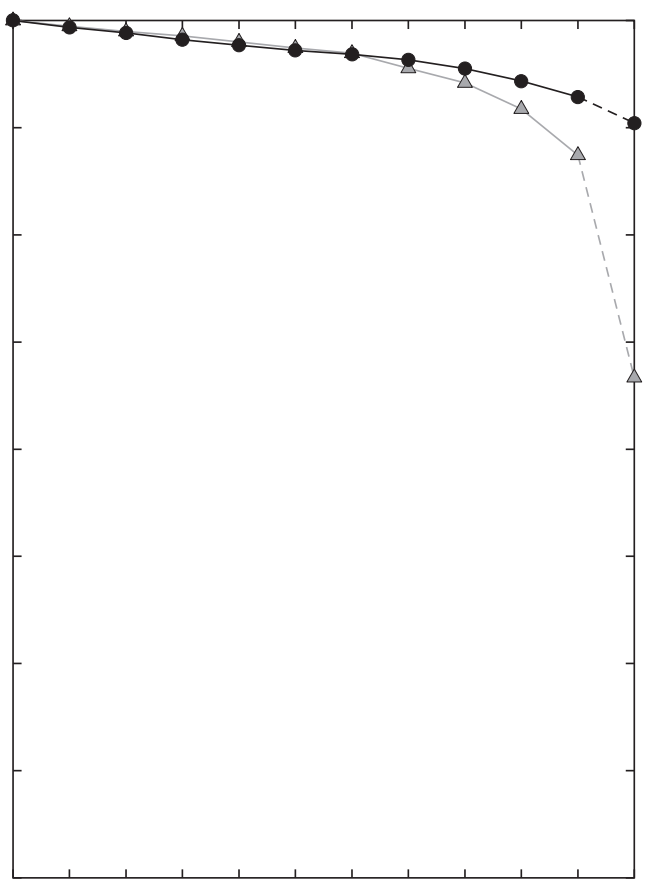

Altitude 200 feet

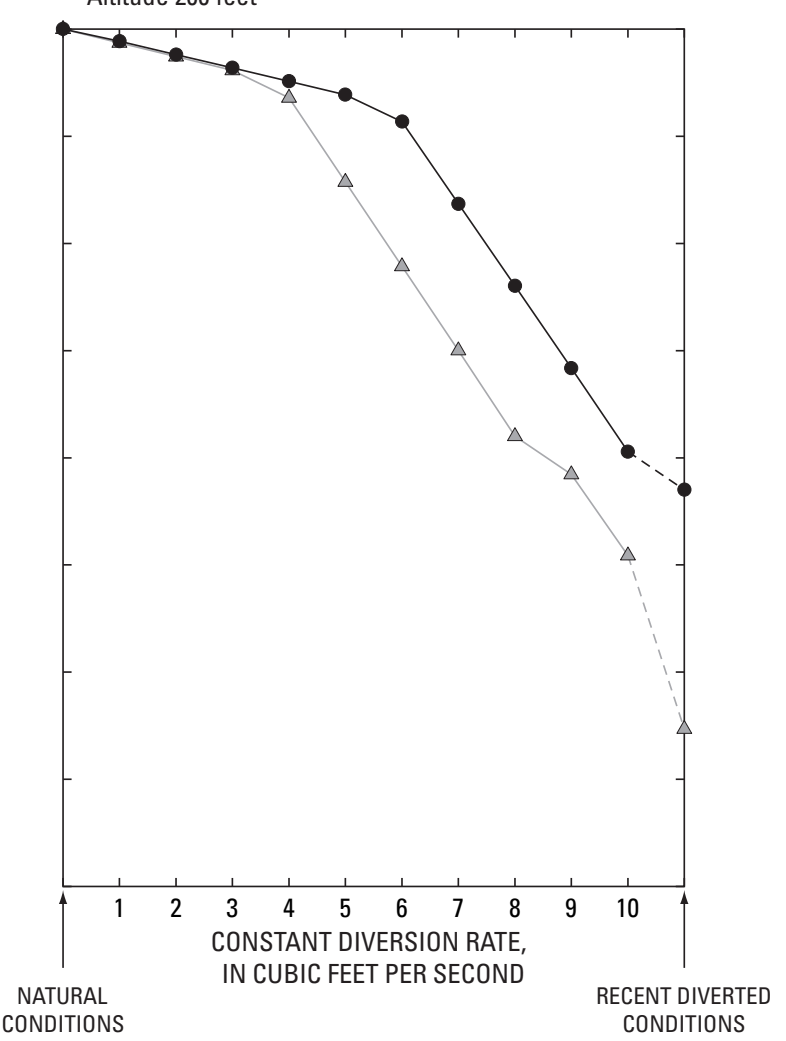

Figure 31. Relation for Neritina granosa (hihiwai) between diversion condition and habitat (in terms of change in weighted usable area relative to natural conditions), Punaluu Stream, Oahu, Hawaii. 

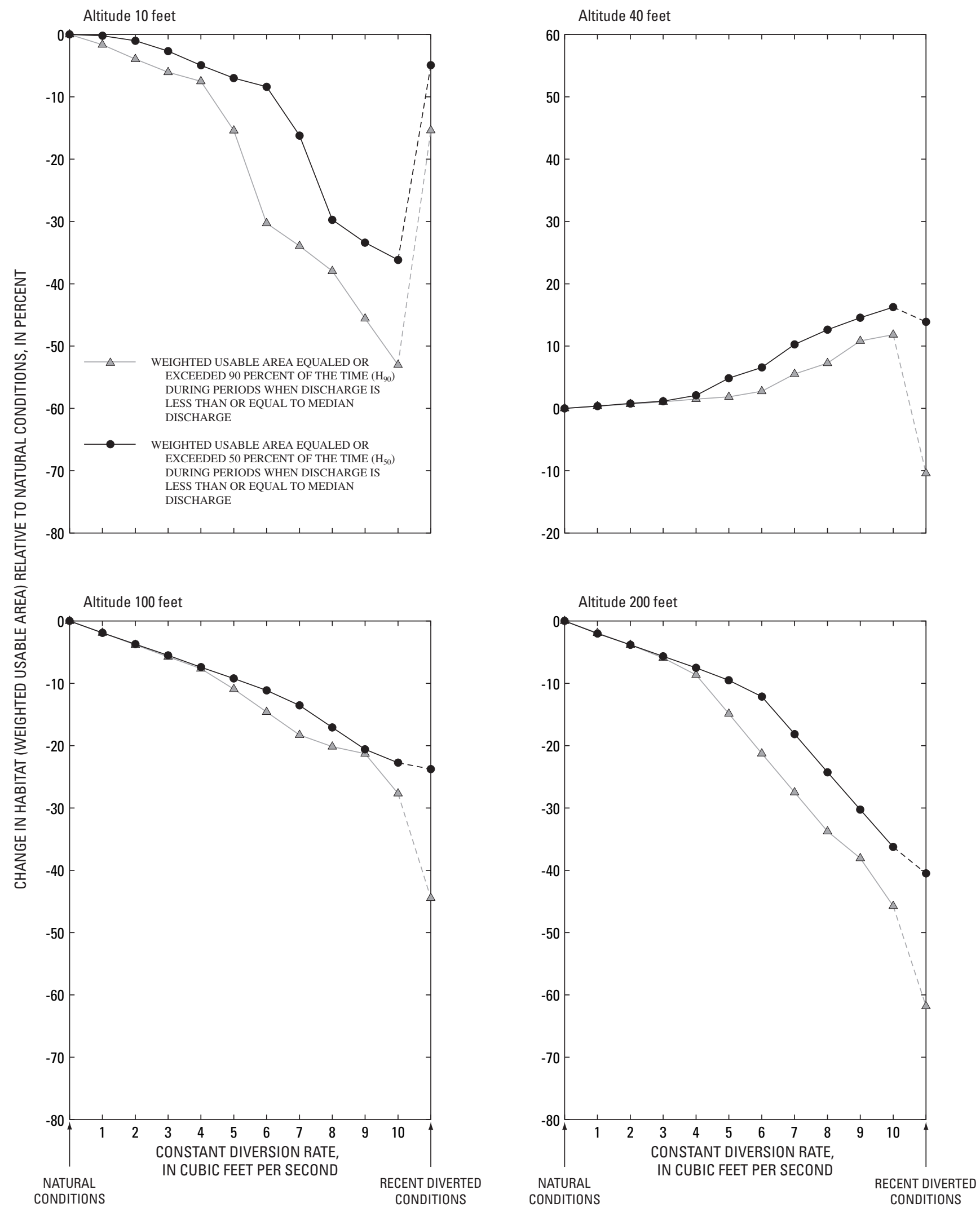

Figure 32. Relation for Awaous guamensis (oopu nakea) between diversion condition and habitat (in terms of change in weighted usable area relative to natural conditions), Punaluu Stream, Oahu, Hawaii. 
Altitude 10 feet

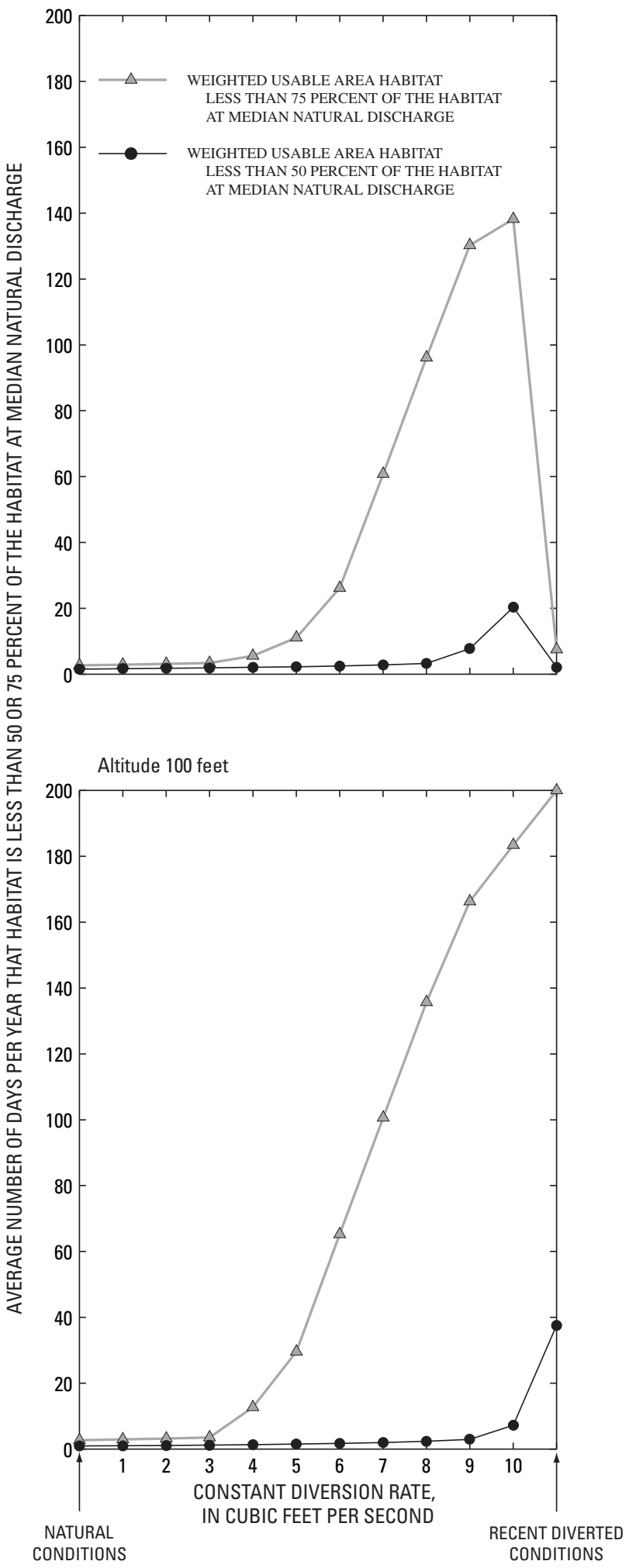

Altitude 40 feet

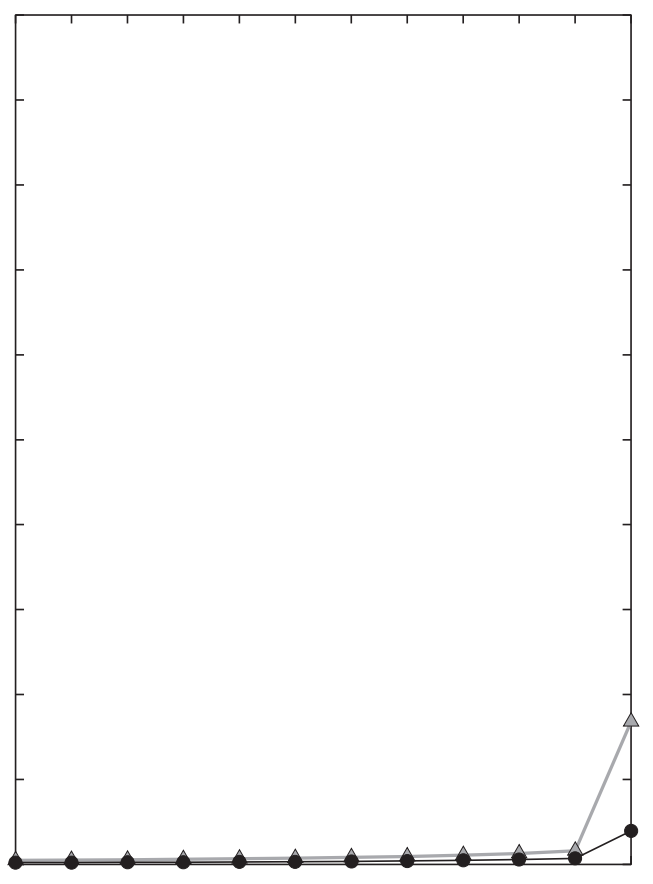

Altitude 200 feet

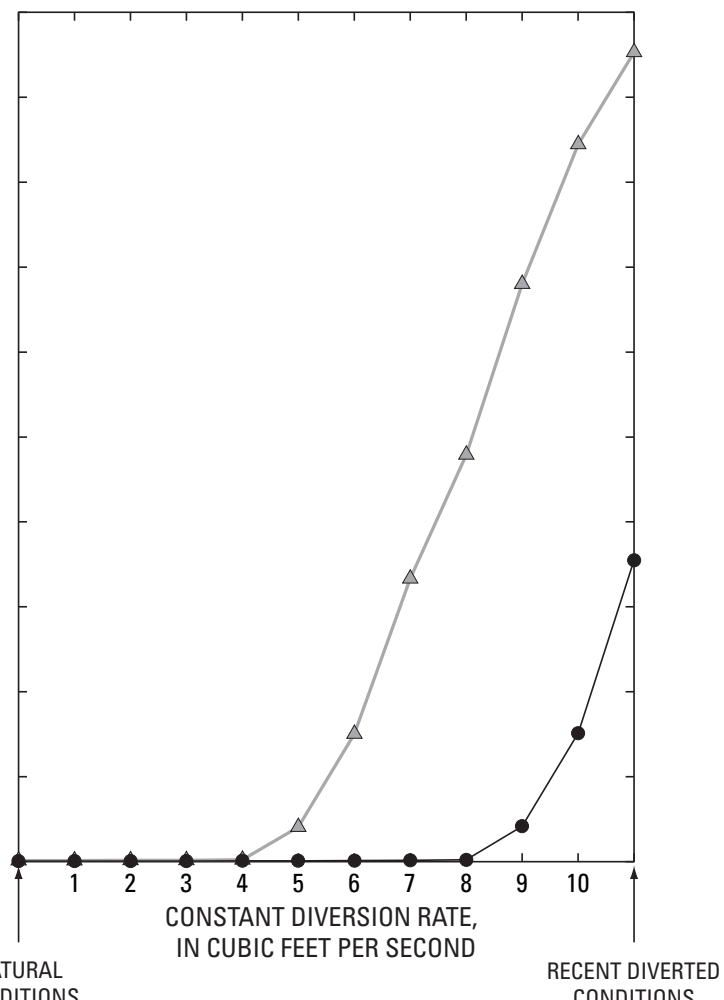

Figure 33. Relation for Neritina granosa (hihiwai) between diversion condition and average number of days per year that habitat is less than 50 or 75 percent of the habitat at median natural discharge, Punaluu Stream, Oahu, Hawaii. The number of days was determined for periods when the discharge was less than or equal to the median natural discharge. 
per year that WUA values are less than 75 percent of the WUA value at median natural discharge increases substantially for constant diversion rates above about $4-5 \mathrm{ft}^{3} / \mathrm{s}$, and (2) WUA values are less than 75 percent of the WUA value at median natural discharge for 138 to 183 days per year for a constant diversion rate of $10 \mathrm{ft}^{3} / \mathrm{s}$.

\section{Awaous guamensis (oopu nakea)}

At stream altitudes of 10, 100, and $200 \mathrm{ft}, \mathrm{H}_{50}$ and $\mathrm{H}_{90}$ values for Awaous guamensis decrease with increasing diversion rates within the range of 1 to $10 \mathrm{ft}^{3} / \mathrm{s}$ (fig. 32). At stream altitudes of 10,100 , and $200 \mathrm{ft}$, (1) $\mathrm{H}_{50}$ values are reduced by less than 10 percent, relative to the corresponding values for natural conditions, for constant diversion rates of 1 to $5 \mathrm{ft}^{3} / \mathrm{s}$; (2) $\mathrm{H}_{50}$ values are reduced by 23 to 37 percent for a constant diversion rate of $10 \mathrm{ft}^{3} / \mathrm{s}$; (3) $\mathrm{H}_{90}$ values are reduced by less than 16 percent, relative to the corresponding values for natural conditions, for constant diversion rates of 1 to $5 \mathrm{ft}^{3} / \mathrm{s}$; and (4) $\mathrm{H}_{90}$ values are reduced by 27 to 53 percent for a constant diversion rate of $10 \mathrm{ft}^{3} / \mathrm{s}$.

At stream altitudes of 10,100, and $200 \mathrm{ft}$, the relations between WUA and discharge for Awaous guamensis (figs. 25, 27, and 28) indicate maximum WUA values at or near the median natural discharge. In contrast, at a stream altitude of $40 \mathrm{ft}$, the relation between WUA and discharge (fig. 26) indicates a maximum WUA value at a discharge rate that is significantly lower than the median natural discharge. The shape of the relation between WUA and discharge at a stream altitude of $40 \mathrm{ft}$ indicates that WUA values greater than the WUA value at natural median discharge can be attained for discharge rates between about $3 \mathrm{ft}^{3} / \mathrm{s}$ to the natural median discharge $\left(21 \mathrm{ft}^{3} / \mathrm{s}\right)$. If the shape of the relation between WUA and discharge is accurate, reducing streamflow by diverting water from Punaluu Stream may result in a predicted increase in WUA, relative to natural-habitat conditions at a stream altitude of $40 \mathrm{ft}$, although total habitat will decrease with decreasing streamflow. At a stream altitude of $40 \mathrm{ft}, \mathrm{H}_{50}$ and $\mathrm{H}_{90}$ values for $A$. guamensis increase with increasing diversion rates within the range of 1 to $10 \mathrm{ft}^{3} / \mathrm{s}$ (fig. 32). Although this result is consistent with the shape of the relation between WUA and discharge at a stream altitude of $40 \mathrm{ft}$, it may reflect a limitation associated with transferring suitability curves from northeast Maui streams (Gingerich and Wolff, 2005) to some reaches in Punaluu Stream. The reaches at 100 and $200 \mathrm{ft}$ in Punaluu Stream are most similar to northeast Maui streams for which habitat-suitability criteria were developed.

For natural-flow conditions, WUA values are less than 75 percent of the WUA values at median natural discharge at stream altitudes of 10, 40, 100, and $200 \mathrm{ft}$ for fewer than 3 days per year (on average). For recent diverted conditions, the average number of days per year that WUA values are less than 50 or 75 percent of the WUA value at median natural discharge generally (1) decreases in a downstream direction, reflecting the effects of tributary inflows and ditch return flows, (2) is less than the corresponding number of days for constant diversion rates greater than about $4-5 \mathrm{ft}^{3} / \mathrm{s}$ at a stream altitude of $10 \mathrm{ft}$, and (3) is greater than the corresponding number of days for a constant diversion rate of $10 \mathrm{ft}^{3} / \mathrm{s}$ at stream altitudes of 40, 100, and $140 \mathrm{ft}$ (fig. 34). At stream altitudes of 10, 40, 100, and $200 \mathrm{ft}$ and for constant diversion rates of up to $8 \mathrm{ft}^{3} / \mathrm{s}$, WUA values are less than 50 percent of the WUA value at median natural discharge for fewer than 4 days per year (fig. 34). At a stream altitude of $200 \mathrm{ft}$ and for a constant diversion rate of $10 \mathrm{ft}^{3} / \mathrm{s}$, WUA values are less than 50 percent of the WUA value at median natural discharge for about 30 days per year. At stream altitudes of 10, 40, 100, and $200 \mathrm{ft}$ and for constant diversion rates of up to $4 \mathrm{ft}^{3} / \mathrm{s}$, WUA values are less than 75 percent of the WUA value at median natural discharge for fewer than 7 days per year. At stream altitudes of 10, 100, and $200 \mathrm{ft}$, (1) the average number of days per year that WUA values are less than 75 percent of the WUA value at median natural discharge increases substantially for constant diversion rates above about $5 \mathrm{ft}^{3} / \mathrm{s}$, and (2) WUA values are less than 75 percent of the WUA value at median natural discharge for 131 to 170 days per year for a constant diversion rate of $10 \mathrm{ft}^{3} / \mathrm{s}$.

\section{Limitations}

One of the main limitations of the analysis to evaluate the effects of different diversion scenarios on physical habitat is that habitat-suitability criteria specific to Punaluu Stream were not developed in this study. Habitat-suitability criteria from northeast Maui streams were assumed to be transferable to Punaluu Stream. Although the accuracy of this assumption could not be rigorously tested, results from Gingerich and Wolff (2005) indicate that habitat-suitability criteria developed for northeast Maui streams in some cases are transferable to other areas of the State. Habitat-suitability curves specific to Punaluu Stream were not developed for this study because existing populations of native species in the study reaches were considered too small. Furthermore, suitable habitat for Eleotris sandwicensis (oopu akupa) and Stenogobius hawaiiensis (oopu naniha), which were both observed in Punaluu Stream, was not modeled in this study because habitat-suitability criteria were not available. Establishing habitat-suitability criteria specifically for Punaluu Stream would lead to an improved understanding of the effects of diverting water from the stream on suitable habitat. In addition, direct measurement of WUA over a broader range of flows would preclude the need to use modeling techniques to extrapolate measured velocities, depths, and habitat. This study does not address the effects of flow diversion on native species abundance, algae and invertebrate food sources for native macrofauna, and flows necessary for reproduction and recruitment of native species. 

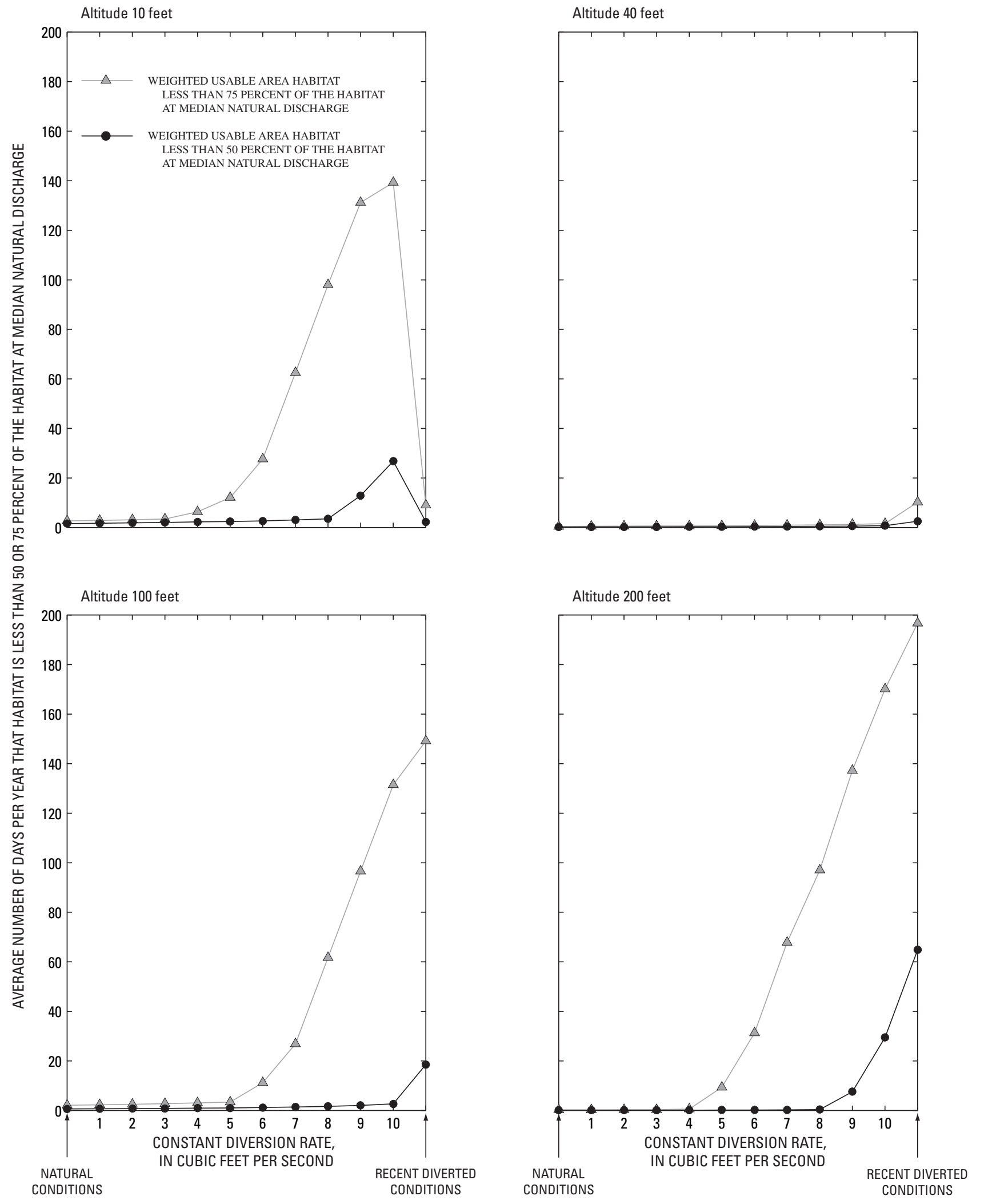

Figure 34. Relation for Awaous guamensis (oopu nakea) between diversion condition and average number of days per year that habitat is less than 50 or 75 percent of the habitat at median natural discharge, Punaluu Stream, Oahu, Hawaii. The number of days was determined for periods when the discharge was less than or equal to the median natural discharge. 


\section{Effects of Surface-Water Diversion on Stream Temperatures}

Diversion of water from Punaluu Stream near an altitude of $210 \mathrm{ft}$ results in decreased flow and possibly increased stream temperatures. Reduced streamflow will lead to lower water velocities and longer travel times for water to flow to the ocean. Because of the longer travel times, water is exposed to potential heating from the sun for longer periods. Stream temperature is a factor that could potentially affect the abundance and distribution of native aquatic species. Hathaway (1978) indicated that the upper-lethal-temperature limits for native aquatic species generally range from about $35^{\circ} \mathrm{C}$ to $40^{\circ} \mathrm{C}$.

To evaluate the effects of diversion of water on stream temperatures, temperature-recording sensors (thermistors) were placed immediately upstream and about $100 \mathrm{ft}$ downstream from the Punaluu Ditch diversion intake near an altitude of $210 \mathrm{ft}$. In addition, temperature-recording sensors were placed at stream altitudes of $100,45,30$, and $10 \mathrm{ft}$. The sensors generally were placed near the stream thalweg (low point in the stream) to ensure that they remained submerged for all flow conditions that occurred during the study period and that water continuously flowed past the sensors. Temperature measurements during low-flow conditions at the selected sites indicated that temperatures generally were uniform throughout each stream cross section, except in shallow areas near the stream edges where water velocities were low. All temperature-recording sensors were programmed to measure temperature at 15-minute intervals during the 13-month period between June 2004 and July 2005.

\section{Daily Mean Temperatures}

During June 2004 to July 2005, daily mean temperatures in Punaluu Stream for recent (diverted) conditions ranged from $18.6^{\circ} \mathrm{C}$ to $23.0^{\circ} \mathrm{C}$ (fig. 35). For comparison, groundwater temperatures measured by BWS in well 3553-05 (fig. 3), located near the coast, generally range from about $21^{\circ} \mathrm{C}$ to $24^{\circ} \mathrm{C}$. Daily mean temperatures were highest (ranging from $20.7^{\circ} \mathrm{C}$ to $23.0^{\circ} \mathrm{C}$ ) during the months of June through September, which are part of the dry season, and lowest (ranging from $18.7^{\circ} \mathrm{C}$ to $21.4^{\circ} \mathrm{C}$ ) during the months of December through March, which are part of the wet season (fig. 35).

Stream temperatures measured immediately upstream and downstream from the Punaluu Ditch intake do not indicate a significant change in temperature caused by a reduction in flow (fig. 35), probably because of the short distance between measurement sites and also because sufficient flow remained in the stream downstream from the Ditch intake during the period of study. However, stream temperatures generally increased farther downstream. The increase in temperature in a downstream direction is caused partly by exposure of the water to solar radiation and frictional heating, and also is related to inflows of warmer water from natural tributar- ies, ditch-return flows, irrigation water that is returned to the stream, and possibly the shallow ground-water body.

The longitudinal-temperature gradient, as measured by the differences in daily mean temperatures at altitudes of 210 and $10 \mathrm{ft}$, was greatest during the months of June through September, and lowest during the months of December through March (fig. 35). During the months of June through September, the temperature at an altitude of $10 \mathrm{ft}$ was about $1{ }^{\circ} \mathrm{C}$ to $1.8^{\circ} \mathrm{C}$ warmer than at an altitude of $210 \mathrm{ft}$, whereas during the months of December through March, the temperature at an altitude of $10 \mathrm{ft}$ was about $0.5^{\circ} \mathrm{C}$ to $1^{\circ} \mathrm{C}$ warmer than at an altitude of $210 \mathrm{ft}$. The longitudinal-temperature gradient also was reduced during periods of heavy rainfall, as indicated by periods of high streamflow (fig. 35). The reduced longitudinal-temperature gradient during rainy periods may be related to factors including: (1) direct runoff of uniform temperature entering along the length of the stream; (2) a smaller altitudinal air-temperature gradient during rainy periods; (3) a reduced effect of ditch-return flows and irrigation water entering the stream; and (4) increased water velocities and shorter travel times that reduce the possibility for warming of water. The downstream increase in temperature potentially could be reduced if no water were diverted from the stream, although the reduction likely would be small over the range of flows that would be restored.

\section{Diurnal Temperature Variations}

Because exposure to lethal temperatures for short durations, in some cases less than 30 minutes (Hathaway, 1978), can cause death in native aquatic species, maximum and minimum daily temperatures were measured. Temperatures in Punaluu Stream vary on a diurnal basis because of diurnal variations in energy (in the form of solar radiation and longwave radiation) received in the valley. During daytime hours, solar radiation received in the valley causes stream temperatures to increase, whereas during the nighttime, loss of infrared energy from the surface causes stream temperatures to decrease. During the period when temperatures were measured for this study, daily maximum temperatures did not exceed $25^{\circ} \mathrm{C}$ and daily minimum temperatures did not drop below $17.5^{\circ} \mathrm{C}$ at any of the study sites. At all of the study sites, daily maximum temperatures remained below the upperlethal-temperature limits for native aquatic species (Hathaway, 1978).

In general, maximum temperatures occurred during the afternoon hours (between about 13:30 and 16:30 hours) and minimum temperatures occurred near dawn (between about 05:00 and 08:00 hours). Differences between daily maximum and minimum temperatures generally (1) ranged from about $1^{\circ} \mathrm{C}$ to $3^{\circ} \mathrm{C}$, (2) were greatest at the lowest site (10 ft altitude) and least at the highest site (210 ft altitude), and (3) were enhanced during warm, dry periods and reduced during cool, wet periods (fig. 36). 

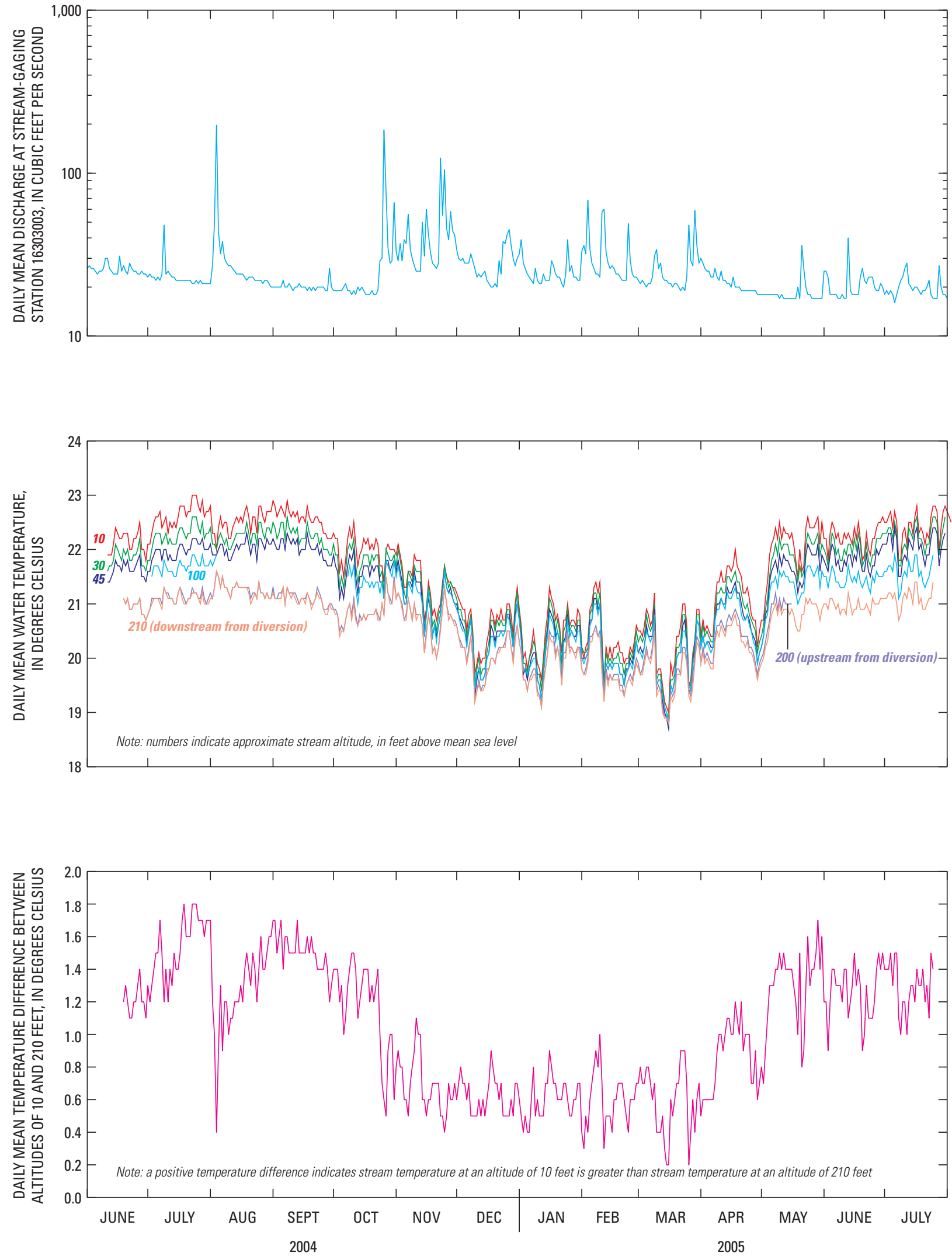

Figure 35. Daily mean discharge at stream-gaging station 16303003, daily mean stream temperatures at altitudes of 10 to 210 feet above mean sea level, and daily mean temperature difference between stream altitudes of 210 and 10 feet, Punaluu Stream, Oahu, Hawaii. 

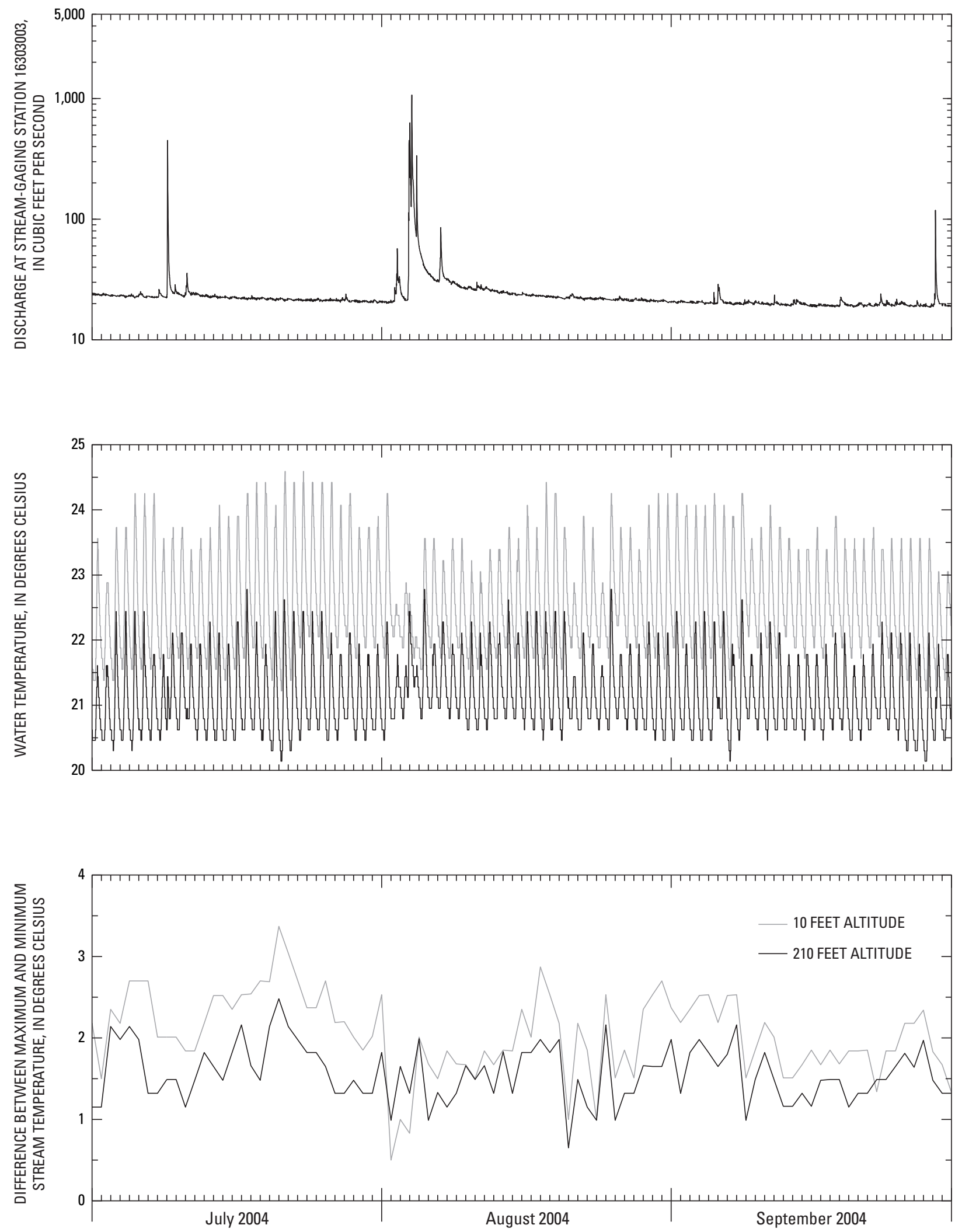

Figure 36. Discharge at stream-gaging station 16303003, stream temperatures at altitudes of 10 and 210 feet above mean sea level, and difference between daily maximum and minimum stream temperatures, Punaluu Stream, Oahu, Hawaii. 


\section{Ground-Water-Flow System}

Ground water currently is the source of almost all domestic water in the study area. The hydraulic properties of the rocks control the modes of ground-water occurrence in the study area. In general, dike-free volcanic rocks are highly permeable. However, low-permeability intrusive dikes, marine and terrestrial coastal sediments, valley-filling older alluvium, and weathered volcanic rocks can have a significant effect on the ground-water system by impeding flow. Within the study area, the main ground-water-flow system consists of dikeimpounded water inland from the coast that may transition to a freshwater lens in dike-free volcanic rocks near the coast (fig. 37) (Gingerich and Oki, 2000). Ground water generally flows from inland areas toward the coast, although local variations from the regional flow directions may be caused by pumped wells or discharge to Punaluu Stream.

\section{Water in the Sedimentary Deposits}

In general, the older valley-filling sedimentary deposits have lower permeability than the dike-free volcanic rocks. Water that infiltrates into the sedimentary deposits may form a saturated ground-water body that is either hydraulically connected to the underlying volcanic rocks or separated from the volcanic rocks by a zone of unsaturated rock (fig. 38). Where ground water in sedimentary deposits is hydraulically connected to ground water in the adjacent volcanic rocks, water may move into or out of the sedimentary deposits, depending on the hydraulic-head distribution. Water moves out of the sedimentary deposits if the hydraulic head in the sedimentary deposits is greater than the head in the underlying volcanic rocks, whereas water moves into the sedimentary deposits if the head in the sedimentary deposits is less than the head in the underlying volcanic rocks. Water in the sedimentary deposits may discharge to underlying volcanic rocks, Punaluu Stream, or the ocean.

\section{Dike-Impounded Water}

Dike-impounded water is found in the rift zones of a volcano where low-permeability dikes have intruded other rocks. A dike-impounded-flow system includes the freshwater body and, where it exists, underlying brackish water and saltwater (fig. 37). Near-vertical dikes tend to compartmentalize areas of permeable volcanic rocks. Dikes impound freshwater to heights of hundreds of feet above sea level in the study area.

Near the coast in the Punaluu area, where few dikes intrude permeable volcanic rocks, the water table generally is only a few feet to a few tens of feet above sea level and brackish water exists below the freshwater. The depth to which freshwater extends below sea level within the dike-impounded system is not known where the water table is high, although freshwater probably extends far below sea level. Sedimentary deposits may confine the dike-impounded ground water in places, although the dike-impounded ground water is mainly unconfined in inland areas.

The dike-impounded system is recharged mainly by direct infiltration of precipitation. Where erosion has exposed dike compartments and the ground-water table extends to the surface, ground water may discharge directly to Punaluu Stream. Many of the perennial tributaries of Punaluu Stream are likely fed by discharge of dike-impounded ground water at high altitudes. The source of Waihoi Springs (fig. 2), which discharges from surface breccia on the west valley wall at an altitude of about $600 \mathrm{ft}$, likely is dike-impounded ground water. Where sedimentary deposits exist in or near the stream channel, they may impede the discharge of freshwater from the dike-impounded system to Punaluu Stream. Fresh ground water in the dike-impounded system also discharges to the downgradient freshwater-lens system.

\section{Freshwater Lens}

A freshwater-lens system includes a lens-shaped freshwater body, an intermediate transition zone of brackish water, and underlying saltwater (fig. 37). Within a freshwater-lens system, fresh ground water generally moves from inland areas to the coast. A saltwater circulation system exists beneath the freshwater lens. Saltwater flows landward in the deeper parts of the aquifer, rises and mixes with seaward flowing freshwater forming a brackish-water transition zone, and then discharges to the ocean. The thicknesses of freshwater and the brackish-water transition zone are controlled by factors including recharge rate, ground-water withdrawal rate, and extent of mixing between freshwater and underlying saltwater.

In the study area, a freshwater-lens system exists in the dike-free volcanic rocks and sedimentary deposits near the coast. Water levels in the freshwater-lens system generally range from a few feet to tens of feet above sea level. The thicknesses of the freshwater and transition zones are monitored by collecting vertical profiles of fluid electrical conductivity, which is an indicator of salinity, from a deep well that is open to the aquifer in the freshwater and transition zones. In the Punaluu area, the BWS has collected vertical salinity profiles from well 3553-05 since 1968. These salinity profiles indicate a brackish-water transition zone that is a few hundred feet thick near well 3553-05 (fig. 39). The freshwater thickness in well 3553-05 has decreased since 1968. This decrease probably is related to increased ground-water withdrawal in the area. Temperature profiles measured by BWS in well 3553-05 indicate ground-water temperatures that range from about $21^{\circ} \mathrm{C}$ to $24^{\circ} \mathrm{C}$.

The freshwater-lens system is recharged mainly by inflow from the upgradient dike-impounded system and also by direct infiltration of precipitation and irrigation water. Discharge from the freshwater-lens system is by diffuse seepage near the coast, to springs, to Punaluu Stream, to the atmosphere by evapotranspiration, and to withdrawal wells. 


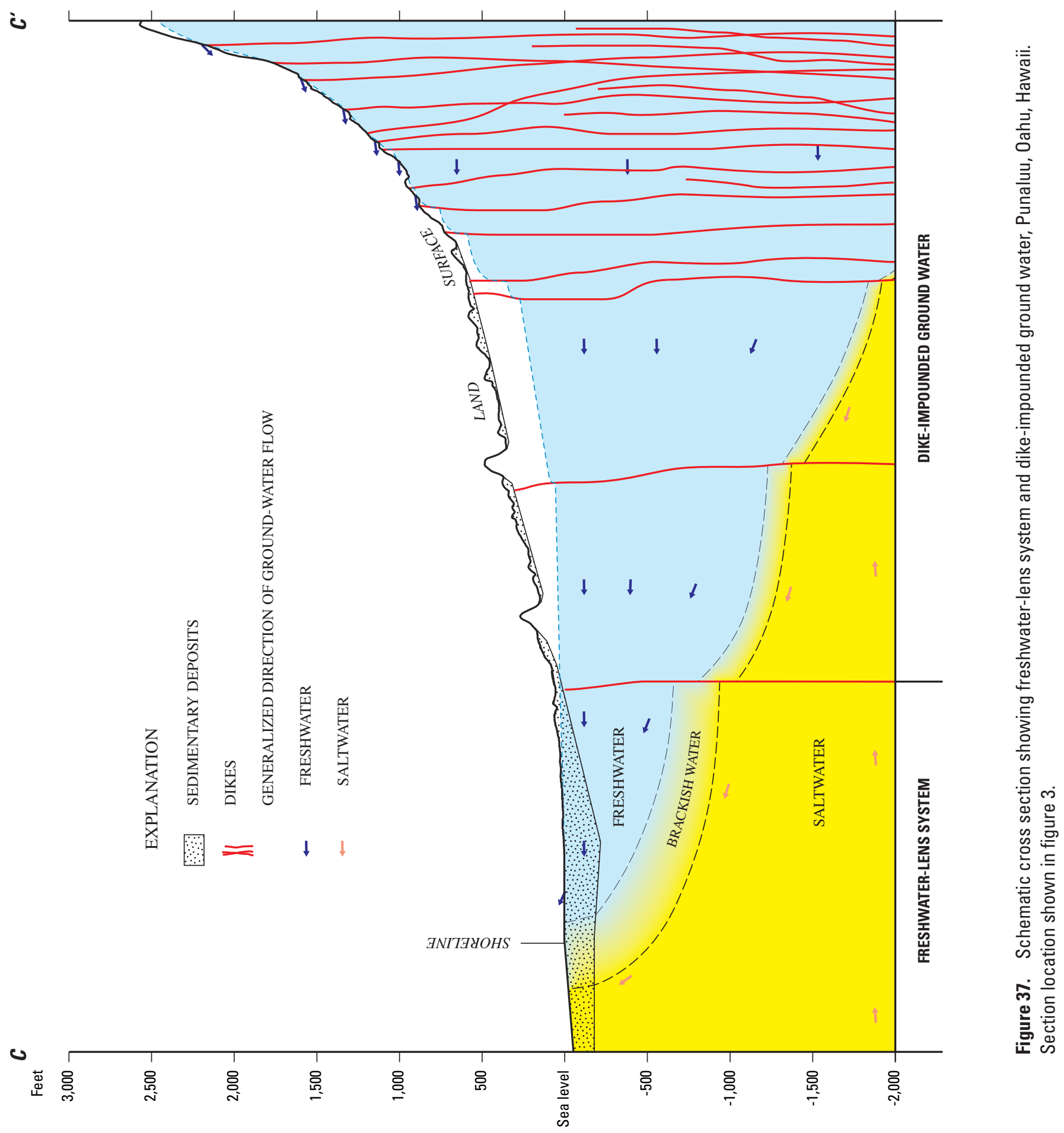






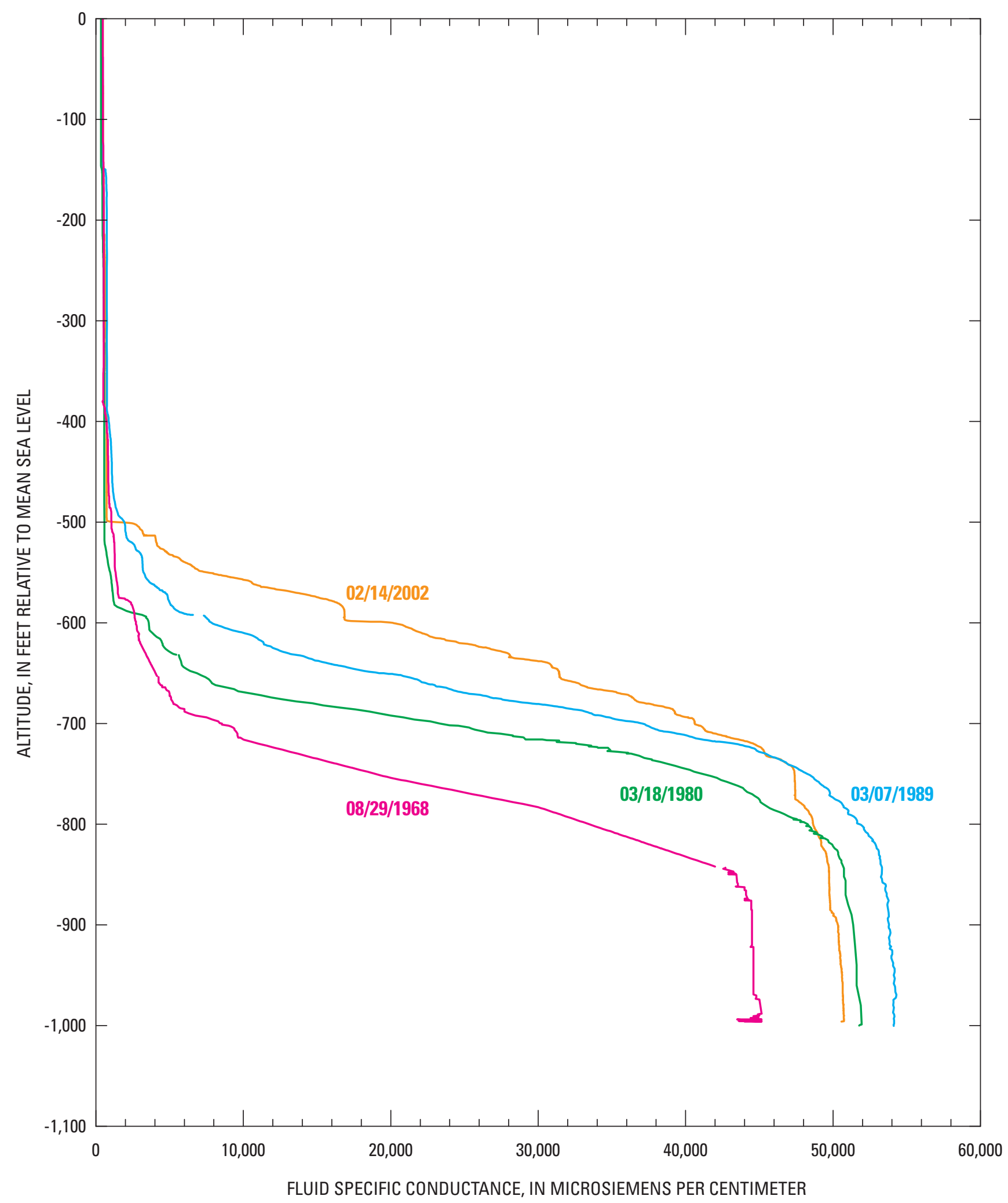

Figure 39. Fluid specific-conductance profiles from Punaluu deep monitor well 3553-05, 0ahu, Hawaii (data provided by Honolulu Board of Water Supply). 
The coastal caprock impedes discharge of freshwater from the volcanic rocks, and causes the freshwater lens to be thicker than it would be without confinement. Ground-water levels in the coastal sedimentary deposits generally are less than a few feet above sea level. Salinity of ground water in the caprock is likely variable and this water is considered part of the freshwater-lens system.

\section{Perched Systems}

Perched water is found in areas where low-permeability rocks impede downward movement of ground water sufficiently to allow a saturated water body to develop within otherwise unsaturated rocks (fig. 38). Low-permeability rocks that may lead to perched water include massive, thickbedded lava flows, buried soil and weathered ash layers, and sedimentary deposits. Within the study area, perched systems may exist in valley-filling deposits, but they are not developed as a resource. The size of a perched system depends on the areal extent of the low-permeability rocks. The height of the water table above sea level in a perched system depends on the altitude of the low-permeability rocks and the rate and duration of recharge. Discharge from a perched system responds to variations in recharge and can be to Punaluu Stream, to springs, downward to a lower water table, or to the atmosphere by evapotranspiration. In some areas, perched water may exist following periods of heavy rainfall, but the rocks may later become unsaturated during an extended dry period.

\section{Withdrawals}

Complete records of ground-water withdrawal from the Punaluu area generally are unavailable prior to 1960 when withdrawals mainly were limited to privately owned domestic and irrigation wells. Many of the early wells were drilled at low altitudes near the coast and penetrated through sedimentary deposits into volcanic rock. Because sedimentary deposits act as a confining unit near the coast, the wells are classified as artesian. In some cases, water pressure in the volcanic-rock aquifer was sufficient to raise the water above the land surface and create free-flowing artesian wells.

Three main production well fields currently are in the Punaluu area (fig. 3). Punaluu I (3553-02) was drilled in 1958. A total of six wells (3553-03, $-04,-06$ to $-08,3554-$ 03) drilled between 1965 and 1967 form the Punaluu II well field. The Punaluu III well field, consisting of two production wells (3453-06, -07), was drilled in 1974. Ground-water withdrawal from Punaluu I generally was between 0.2 and $0.6 \mathrm{Mgal} / \mathrm{d}$ from 1965 to the end of 1999, when withdrawal ceased (fig. 40). Ground-water withdrawal from Punaluu II ranged from about 2 to $8 \mathrm{Mgal} / \mathrm{d}$ between 1970 and 2002, and withdrawal from Punaluu III ranged from about 1 to 1.5 Mgal/d between 1978 and 2002 (fig. 40). During 2000-2002, combined withdrawal from the Punaluu II and III well fields averaged about $6.5 \mathrm{Mgal} / \mathrm{d}$. Withdrawals from Punaluu II and III were reduced toward the end of 2003. During 2004, combined withdrawal from the Punaluu II and III well fields averaged about $2.4 \mathrm{Mgal} / \mathrm{d}$.

Several privately owned wells in the Punaluu area withdraw small amounts of water for domestic or agricultural uses. Total reported withdrawals from two privately owned wells (3453-03 and 3553-01) in the Punaluu area prior to 1997 were less than $0.5 \mathrm{Mgal} / \mathrm{d}$.

\section{Water Levels}

In the Punaluu area, ground-water levels generally are highest near the inland, high recharge areas and lowest near coastal discharge areas. The presence of springs and perennially flowing tributaries indicate that water levels in the dikeimpounded ground-water system probably exceed $600 \mathrm{ft}$ above mean sea level in inland areas. Water levels measured in wells drilled in the mapped marginal dike zone (Takasaki and Mink, 1985) generally are less than $25 \mathrm{ft}$ above mean sea level (fig. 41). Water levels in wells southeast of Punaluu Stream and within about $1,500 \mathrm{ft}$ of the coast generally are less than $10 \mathrm{ft}$ above mean sea level.

The water level in Punaluu well VA (3454-01), which is within the mapped marginal dike zone (Takasaki and Mink, 1985 ) about $6,300 \mathrm{ft}$ inland from the coast and which currently is the well located farthest inland in the Punaluu area, was $19.50 \mathrm{ft}$ above mean sea level on May 19, 2005. The water level in Punaluu well VB (3453-10), also located within the mapped marginal dike zone but about 4,300 $\mathrm{ft}$ inland from the coast, was $26.38 \mathrm{ft}$ above mean sea level on May 19, 2005. The water level in Punaluu VB was higher than the water level in Punaluu VA, although Punaluu VB is located closer to the coast than Punaluu VA. Possible reasons for the higher water level in the well located closer to the coast include: (1) the wells may be drilled in material with different hydraulic characteristics such that water levels respond differently to changes in recharge or withdrawal; (2) the wells may be drilled in separate dike compartments with different water levels; or (3) the wells may be separated by a relatively low-permeability valley-fill barrier composed of valley-filling sedimentary deposits and underlying weathered basalt associated with Punaluu Stream. Concurrent water-level data collected at 15-minute intervals from Punaluu wells VA and VB from May 19 to July 26, 2005 indicate different short-term responses to natural and human-induced factors (fig. 42). Water levels in Punaluu VA show short-term changes in response to ocean tides and ground-water withdrawals, whereas short-term water-level changes in Punaluu VB are much more subdued. The waterlevel variations measured in Punaluu VB indicate that the well is likely drilled in low-permeability material.

Makalii well 2 (3453-12) and Makalii well 2A (3453-16) are located about $600 \mathrm{ft}$ apart and just seaward of the marginal dike zone defined by Takasaki and Mink (1985). On May 19, 2005, water levels measured in Makalii wells 2 and 2A, respectively, were 12.96 and $8.25 \mathrm{ft}$ above mean sea level. 

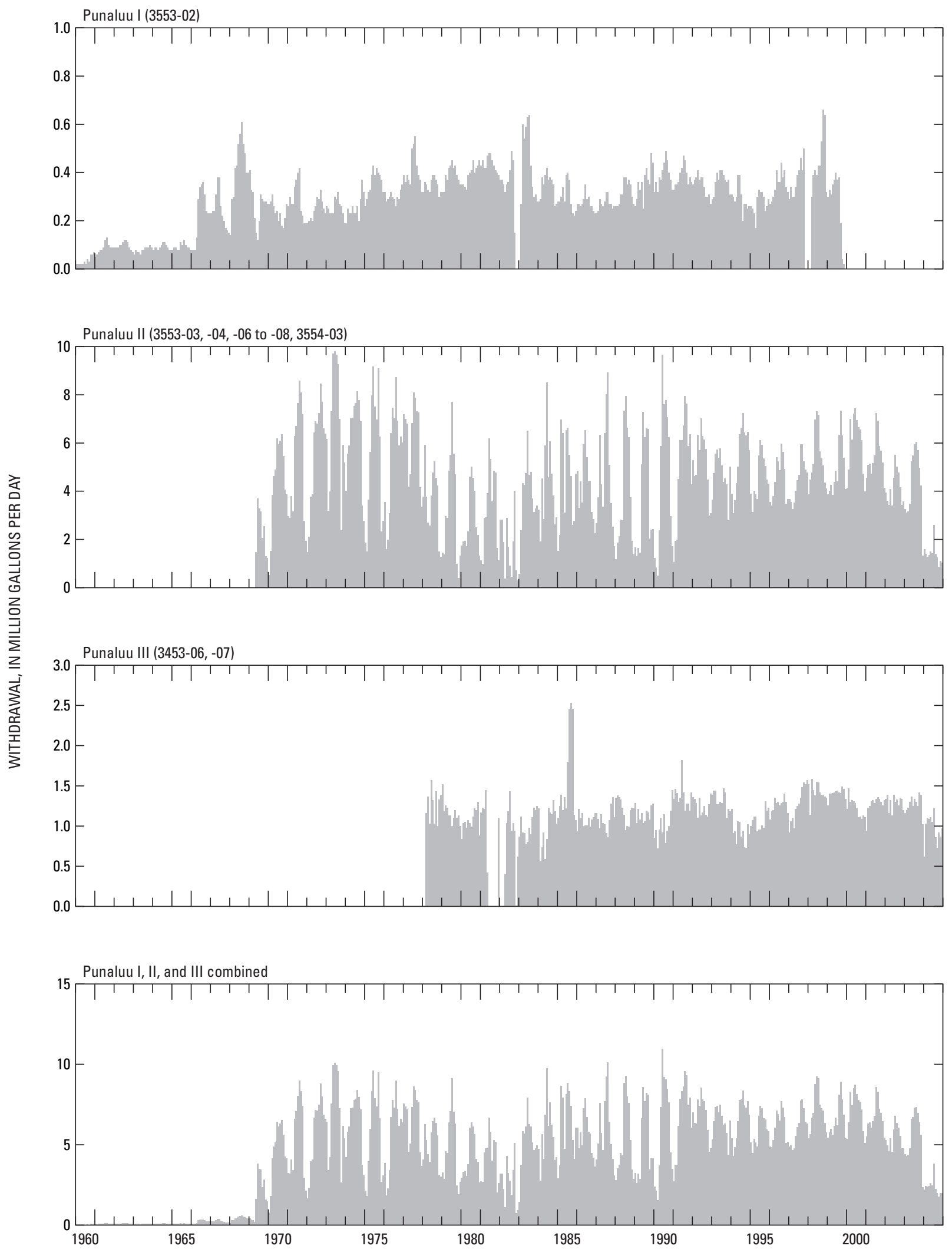

Figure 40. Ground-water withdrawal from Punaluu well fields I, II, and III, Oahu, Hawaii. Data from unpublished records in USGS Pacific Islands Water Science Center well files and digital database from Hawaii State Commission on Water Resource Management. 


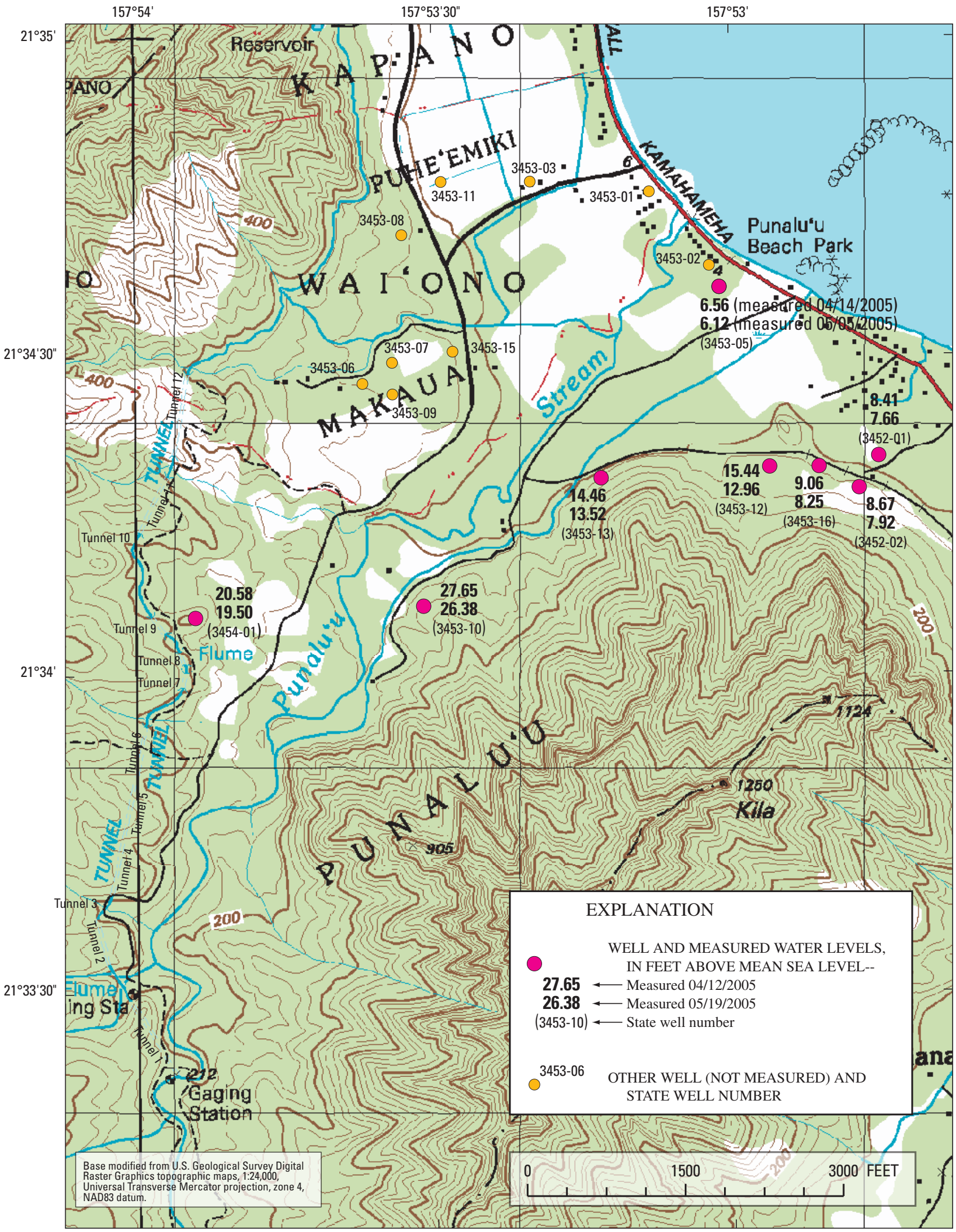

Figure 41. Measured ground-water levels on April 12, 2005 and May 19, 2005 in the Punaluu area, Oahu, Hawaii. 
The difference in water levels between Makalii wells 2 and 2A may indicate that the wells were drilled in separate dike compartments with different water levels, although they are shown outside of the marginal dike zone from Takasaki and Mink (1985). The wells also may be drilled in rocks with different hydraulic characteristics or separated by rocks (unrelated to dikes) of low permeability.

Within the Punaluu area, water levels may vary temporally in response to changes in recharge and ground-water withdrawal, ocean tides, and barometric pressure. Water levels measured in Punaluu deep monitor well 3553-05 declined after about 1968 when withdrawal from the Punaluu II well field began (fig. 43). Water levels in well 3553-05 declined further during the late 1990s, most likely in response to reduced recharge during an extended period of low rainfall. Shorter-term periods of low rainfall also can affect water levels in the Punaluu area. From April 15 through May 15, 2005, daily mean water levels in selected wells in the Punaluu area dropped by about $1 \mathrm{ft}$ and daily mean discharge in Punaluu Stream decreased by about $4 \mathrm{ft}^{3} / \mathrm{s}$ partly because of low rainfall during this period (fig. 44). During the period from April 15 through May 15, 2005, only 3.93 in. of rain fell at rain gage 883.12 near the topographic crest of the Koolau Range, and this total represents about 15 percent of the mean rainfall for this period (Giambelluca and others, 1986).

Water levels in the Punaluu area vary daily in response to natural factors such as ocean tides and barometric pressure. Water levels affected mainly by ocean tides commonly show two maximum and two minimum values in a day, and the times of day at which the maxima and minima occur generally shift over time during a month because ocean tides are composed of numerous tidal components of different phase and frequency (including diurnal, semidiurnal, terdiurnal, and other components). Water levels affected mainly by semidiurnal variations in barometric pressure show two maximum and two minimum values in a day, and the times of day at which the maxima and minima occur generally do not vary much unless a low- or high-pressure weather system approaches the island.

In general, wells located close to the coast are affected by ocean tides to a greater extent than wells located farther inland (figs. 45-48). For example, water levels measured in well 3453-05 (fig. 45), about $600 \mathrm{ft}$ inland from the coast, are affected by ocean tides to a greater extent than water levels measured in Punaluu VA (3454-01) (fig. 48), which is about $6,300 \mathrm{ft}$ from the coast. Because Punaluu VB (3453-10), which is located about $4,300 \mathrm{ft}$ from the coast, is likely drilled in low-permeability material, water levels do not appear to be affected by ocean tides, although water levels may be affected slightly by semidiurnal barometric-pressure variations (fig. 42).

\section{Salinity}

As described previously (see section on "Freshwater Lens"), ground-water salinity in the Punaluu area increases with depth. At a particular depth relative to sea level, salinity generally is expected to increase with proximity to the coast

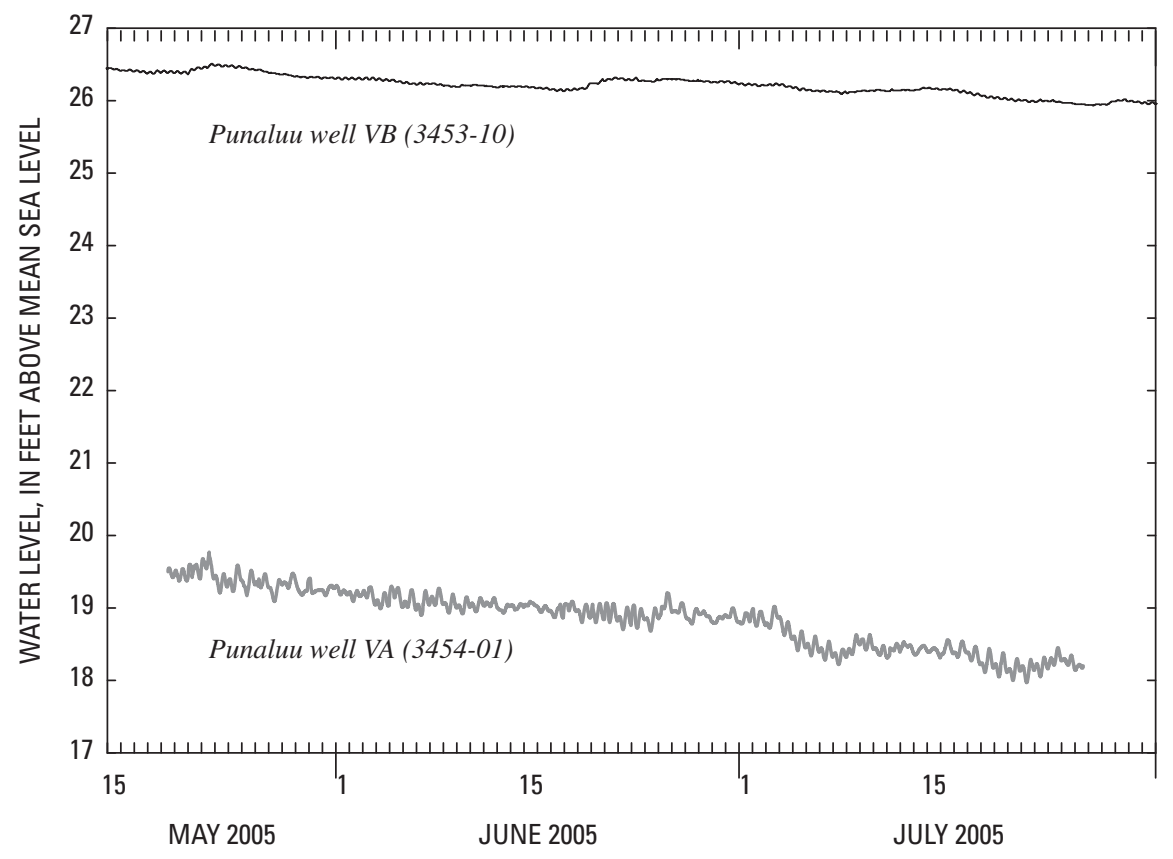

Figure 42. Ground-water levels in Punaluu wells VA (3454-01) and VB (3453-10) during May 15 through July 31, 2005, Oahu, Hawaii. 


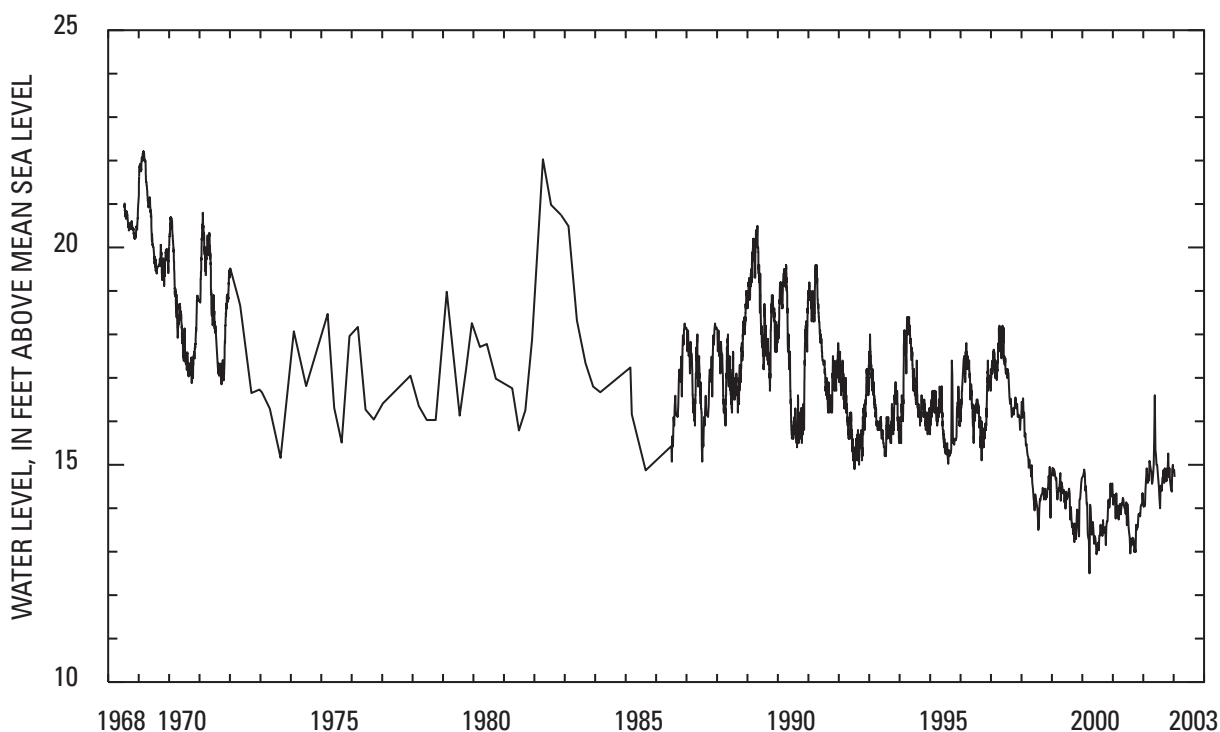

Figure 43. Ground-water levels in Punaluu deep monitor well 3553-05, Punaluu, Oahu, Hawaii. Data from unpublished records in USGS Pacific Islands Water Science Center well files and from Honolulu Board of Water Supply.

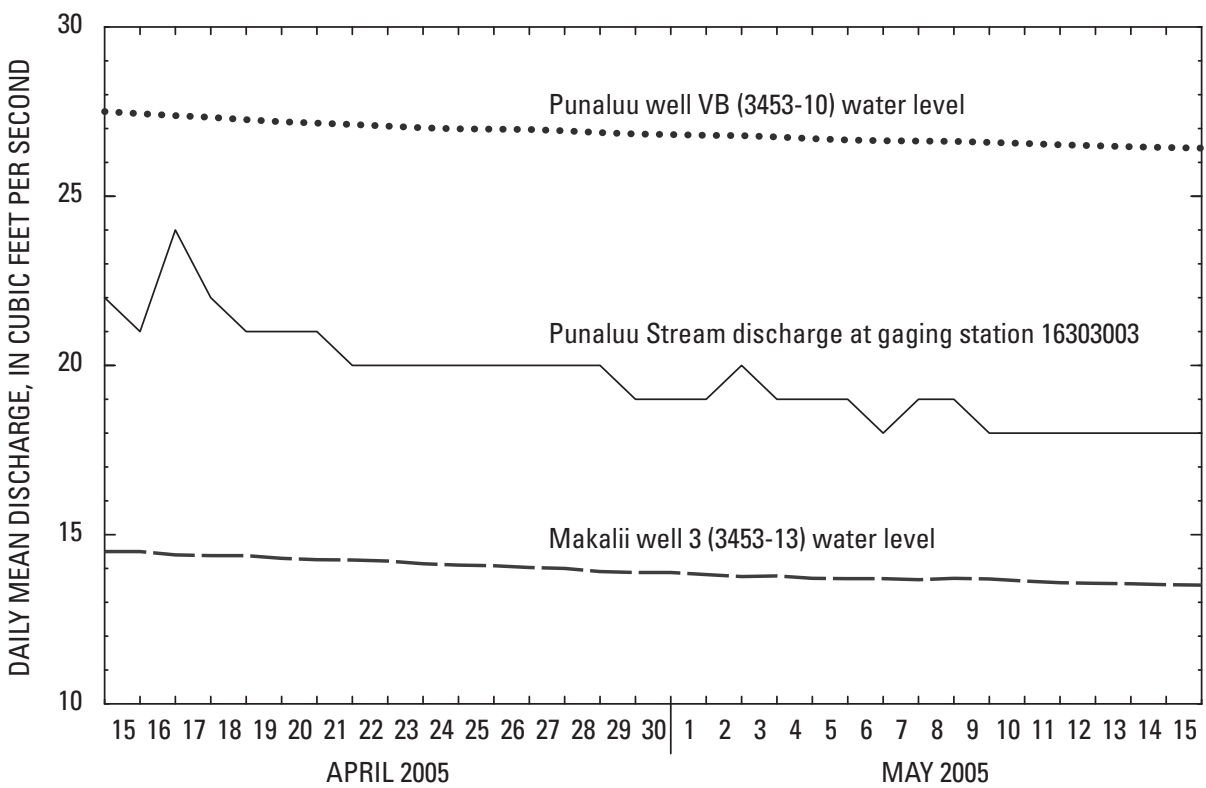

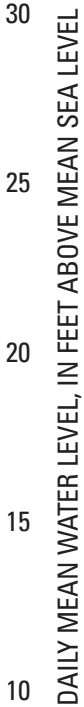

Figure 44. Discharge at Punaluu Stream gaging station 16303003 and water levels in Punaluu well VB (3453-10) and Makalii well 3 (3453-13), Oahu, Hawaii, April 15, 2005 through May 15, 2005. 
Pump timing at Punaluu II, pump 1 (3553-07)
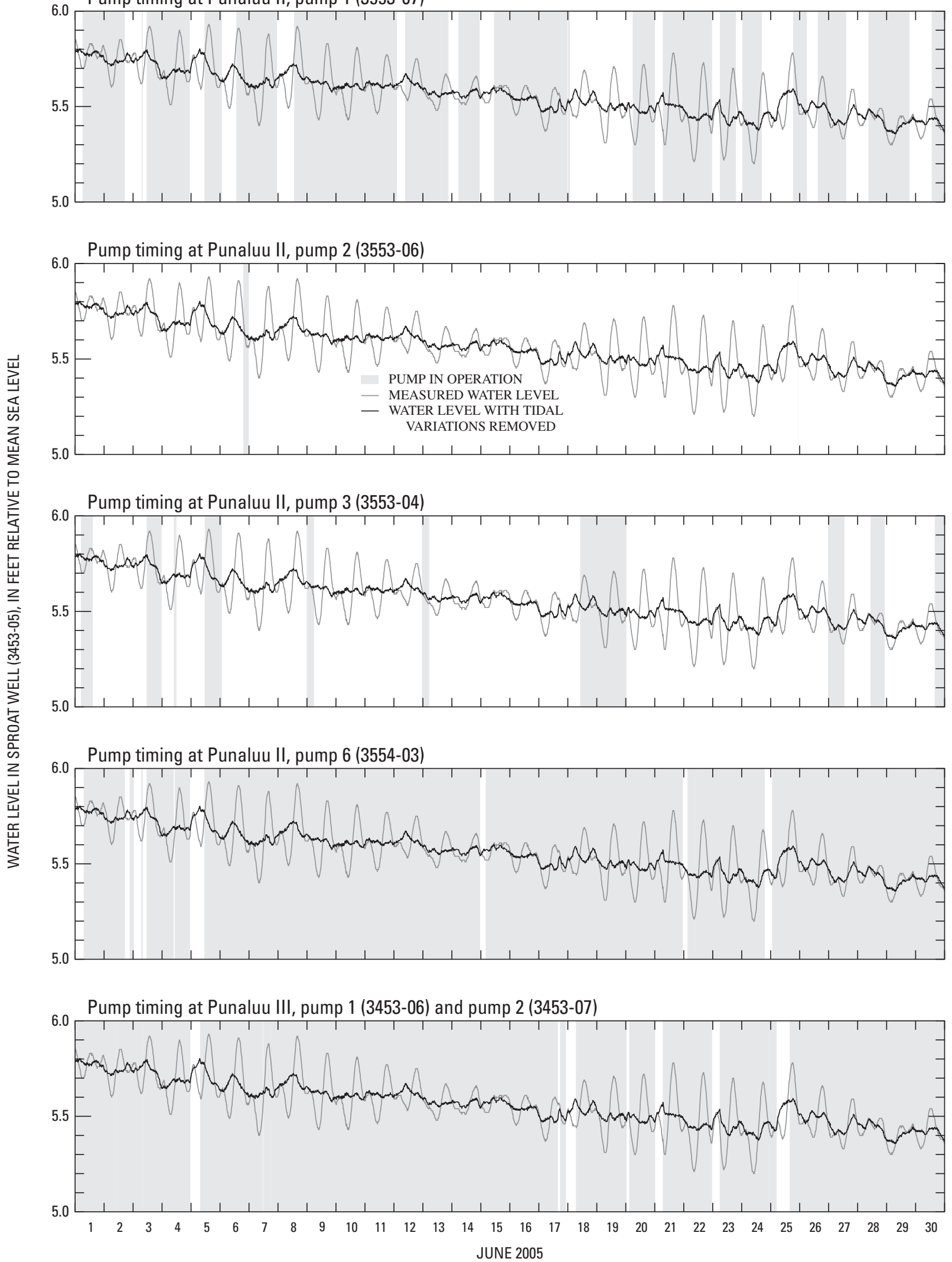

Figure 45. Water levels in Sproat well (3453-05), water levels with tidal variations removed, and pump timing at selected wells in the Punaluu area (shaded areas represent periods when pumps were in operation), Oahu, Hawaii, during June 2005. Information on pump timing from Honolulu Board of Water Supply. 
Pump timing at Punaluu II, pump 1 (3553-07)
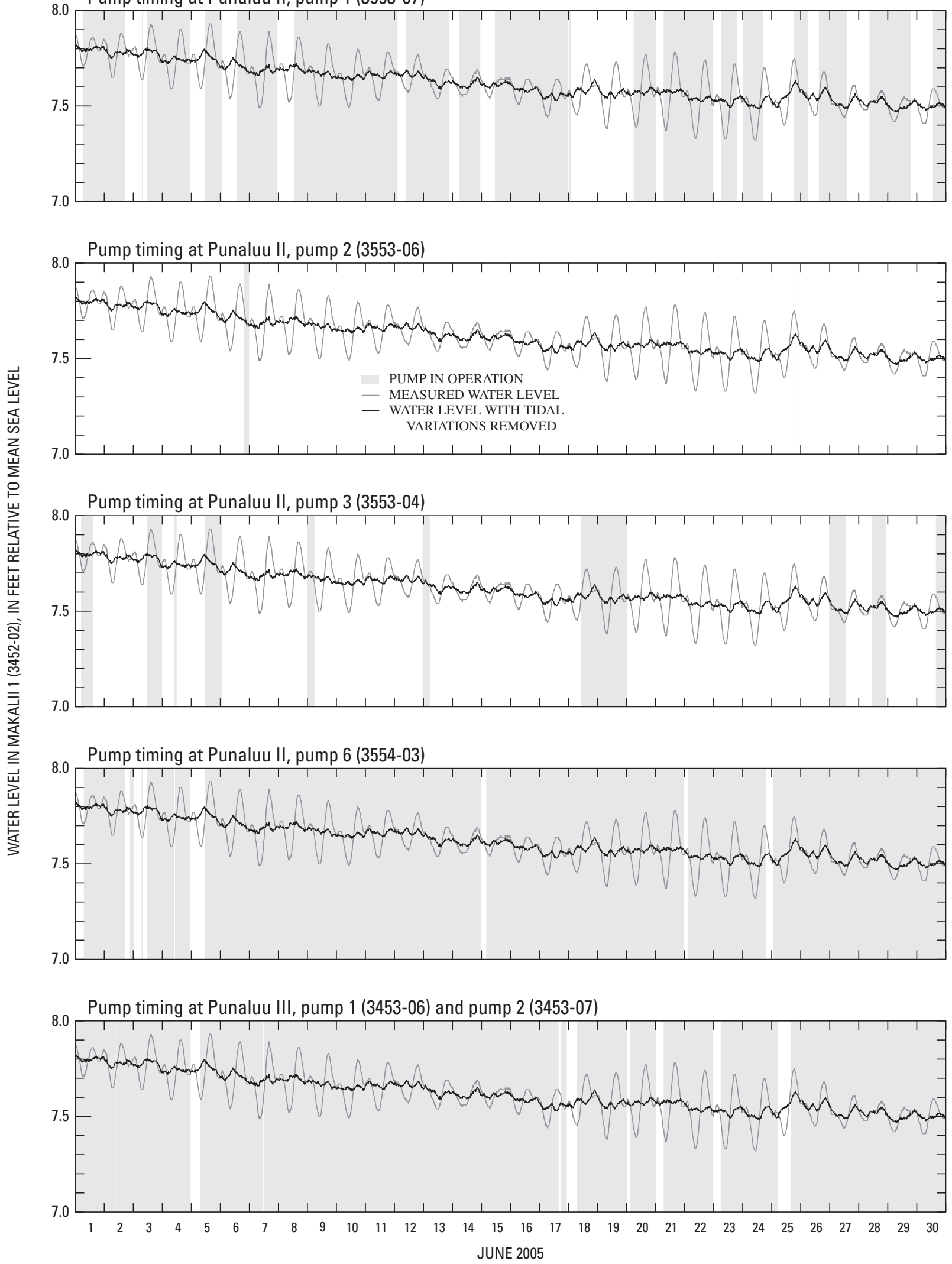

Figure 46. Water levels in Makalii 1 (3452-02), water levels with tidal variations removed, and pump timing at selected wells in the Punaluu area (shaded areas represent periods when pumps were in operation), 0ahu, Hawaii, during June 2005. Information on pump timing from Honolulu Board of Water Supply. 
Pump timing at Punaluu II, pump 1 (3553-07)
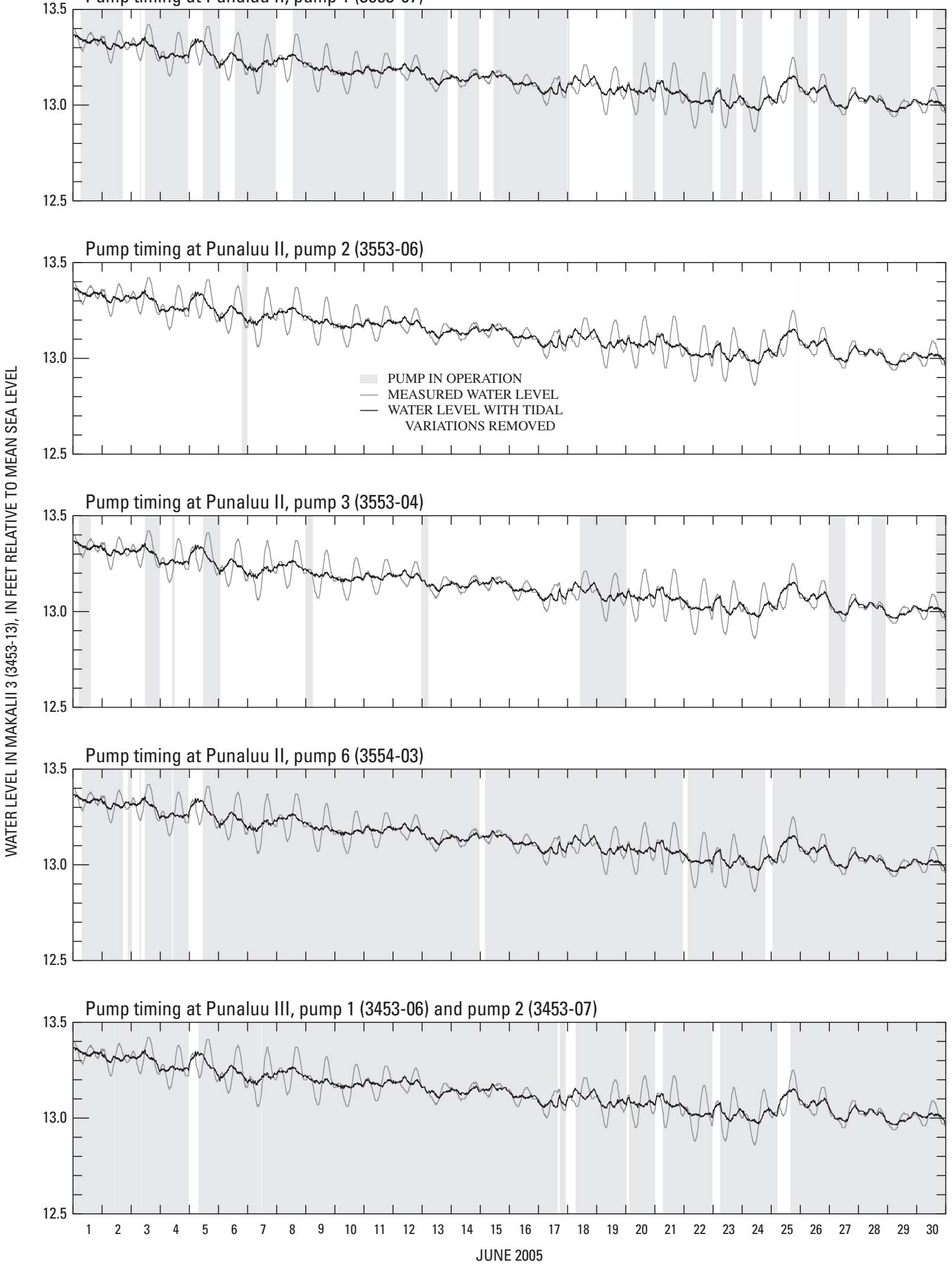

Figure 47. Water levels in Makalii 3 (3453-13), water levels with tidal variations removed, and pump timing at selected wells in the Punaluu area (shaded areas represent periods when pumps were in operation), Oahu, Hawaii, during June 2005. Information on pump timing from Honolulu Board of Water Supply. 
Pump timing at Punaluu II, pump 1 (3553-07)
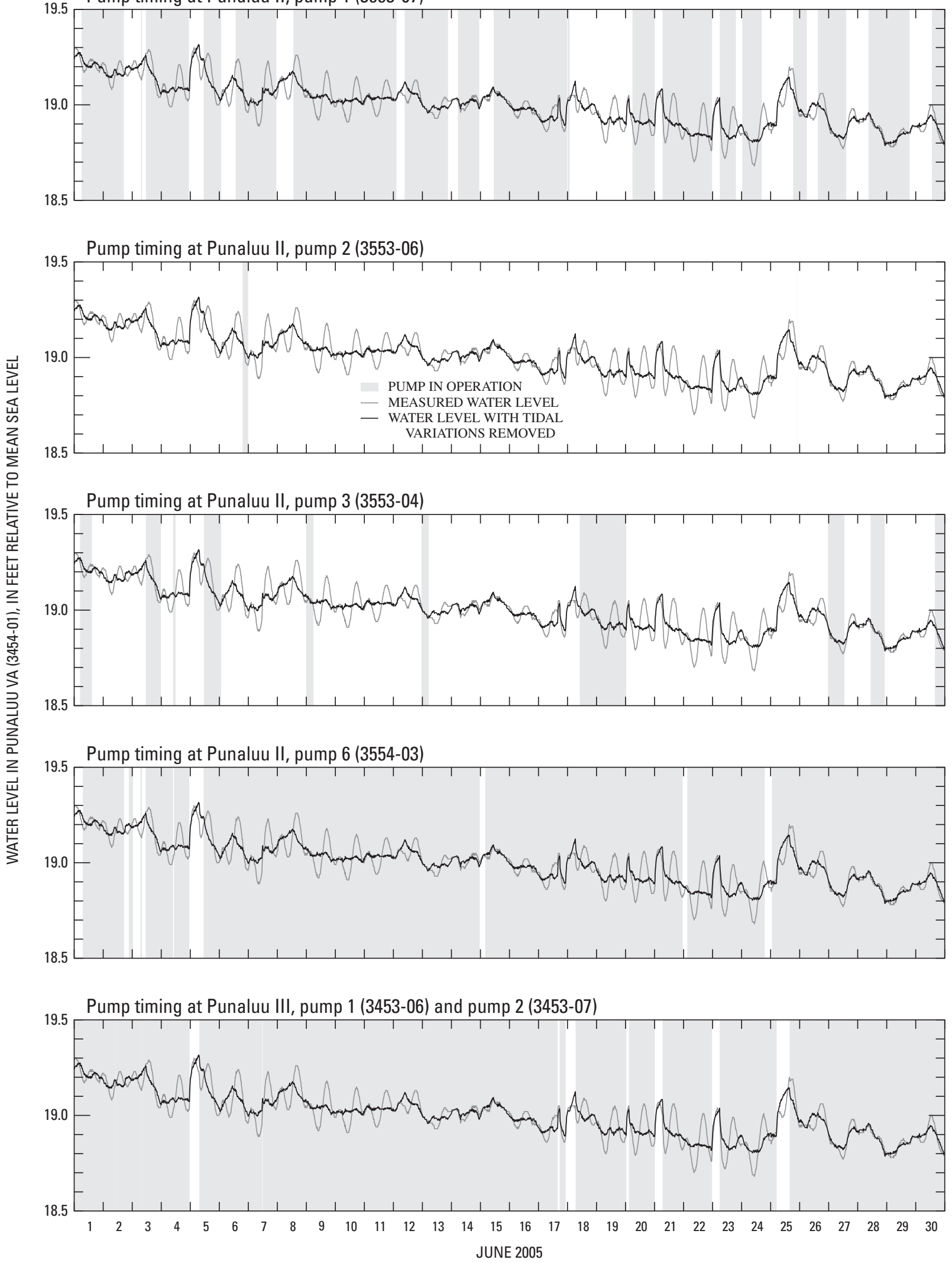

Figure 48. Water levels in Punaluu VA (3454-01), water levels with tidal variations removed, and pump timing at selected wells in the Punaluu area (shaded areas represent periods when pumps were in operation), 0ahu, Hawaii, during June 2005. Information on pump timing from Honolulu Board of Water Supply. 
because the main source of saltwater in the ground-water system is the ocean. The salinity of ground water in Hawaii commonly is measured by chloride concentration, which also is an indicator of saltwater intrusion into the ground-water system. In general, the chloride concentrations of pumped water are expected to increase with depth, proximity to the coast, and pumping rate of the well. Exceptions to this generalization, however, are known to exist in Hawaii. Since the late 1990s, chloride concentrations of pumped water from production wells in the Punaluu area commonly exceeded 100 milligrams per liter $(\mathrm{mg} / \mathrm{L})$, and in some cases chloride concentrations exceeded $250 \mathrm{mg} / \mathrm{L}$ (fig. 49). For comparison, the chloride concentration of rainfall on Oahu generally is a few to a few tens of mg/L (Stearns and Vaksvik, 1935; Visher and Mink, 1964; Dugan and Ekern, 1984), and the chloride concentration of seawater is about $19,500 \mathrm{mg} / \mathrm{L}$ (Wentworth, 1939). On Oahu, fresh ground water used for domestic purposes generally has a chloride concentration less than 150-200 mg/L and commonly less than $50 \mathrm{mg} / \mathrm{L}$.

Since the mid-1990s, chloride concentrations of pumped water from several production wells in the study area have increased over time. The increase in chloride concentrations of pumped water along with the thinning of the freshwater zone over time in the Punaluu area (fig. 39) are consistent with saltwater intrusion, which is characterized by landward and upward movement of brackish water or saltwater into parts of the aquifer that formerly contained freshwater.

\section{Effects of Ground-Water Withdrawal on Streamflow}

Because of the hydraulic connection between Punaluu Stream and the adjacent ground-water body, withdrawals from production wells in the Punaluu area can potentially reduce streamflow. Seepage-run measurements and groundwater-level data collected for this study indicate the potential for interaction between ground water and Punaluu Stream, although quantification of the effects of ground-water withdrawal on streamflow was beyond the scope of this study.

When withdrawal from a well begins, water is initially removed from aquifer storage, and water levels in the vicinity of the well begin to decline. If withdrawal is stopped and ground-water recharge remains steady, water lost from storage eventually will be regained and water levels will recover as the system returns to pre-withdrawal conditions. If withdrawal from the well continues at a steady rate, the zone over which water levels decline expands outward from the well as additional water is removed from storage. Water-level decline is greatest at the withdrawal site and decreases outward from the well, forming what is known as a cone of depression. The cone of depression eventually reaches areas where water is discharging to the ocean or streams, or where recharge to the ground-water body can occur. The shape of the cone of depression generally is not symmetrical because of the pres- ence of low-permeability features or recharge and discharge boundaries. As water levels decline near a discharge area, the rate of discharge decreases; as water levels decline near a potential recharge area, the rate of recharge may increase.

Long-term steady withdrawal of ground water by a well is eventually balanced by enhanced recharge or loss of natural discharge (provided the withdrawal is not greater than the possible balancing sources of water) and water levels cease to decline further. Long-term withdrawal may enhance recharge of water that may otherwise have been (1) lost to evapotranspiration in areas where plants extract ground water from below the water table, or (2) discharged to springs or streams (see for example Lohman, 1979). Long-term withdrawal may lower the water table below the roots of plants or below the level of spring-discharge sites, creating a condition that could lead to enhanced recharge. In areas where long-term steady withdrawal by a well does not result in enhanced recharge, natural discharge is reduced by an amount equal to the withdrawal. In Hawaii, long-term withdrawal of ground water generally results in a reduction of ground-water discharge to the ocean and, in some settings, streams.

Ground-water withdrawal may reduce ground-water discharge to a stream where the stream channel is lower than the water table in the adjacent aquifer. In Hawaii, streams commonly gain water from dike-impounded ground-water bodies in inland areas or from freshwater-lens systems near the coast. In addition, streams may gain shallow ground water from sedimentary deposits that may or may not be hydraulically connected to the main aquifer in underlying volcanic rocks.

\section{Potentially Affected Stream Areas}

Ground-water withdrawals may affect streamflow in reaches where the ground-water body is hydraulically connected to the stream or downstream from these reaches. If the stream and underlying ground-water body are everywhere separated by a zone of unsaturated rock, ground-water withdrawals will not affect streamflow. On the basis of (1) measured water levels in wells relative to stream-channel altitudes (fig. 41) and (2) discharge measurements indicating where the stream commonly gains water, Punaluu Stream is likely connected to the main ground-water body below an altitude of about $25 \mathrm{ft}$ and in inland areas (above altitudes of at least $210 \mathrm{ft}$ ) where the stream gains water from the dike-impounded ground-water body.

Below an altitude of $25 \mathrm{ft}$, sedimentary deposits in the stream channel are likely saturated above sea level because ground water discharges into Punaluu Stream. Punaluu Stream can gain water from volcanic rocks where the hydraulic head in the volcanic rocks is greater than the stream-channel altitude. If the maximum hydraulic head in the volcanic rocks is $25 \mathrm{ft}$, then the channel altitude where the stream can gain water from the volcanic rocks must be less than $25 \mathrm{ft}$ because of frictional head losses associated with ground-water flow through the sedimentary deposits. 

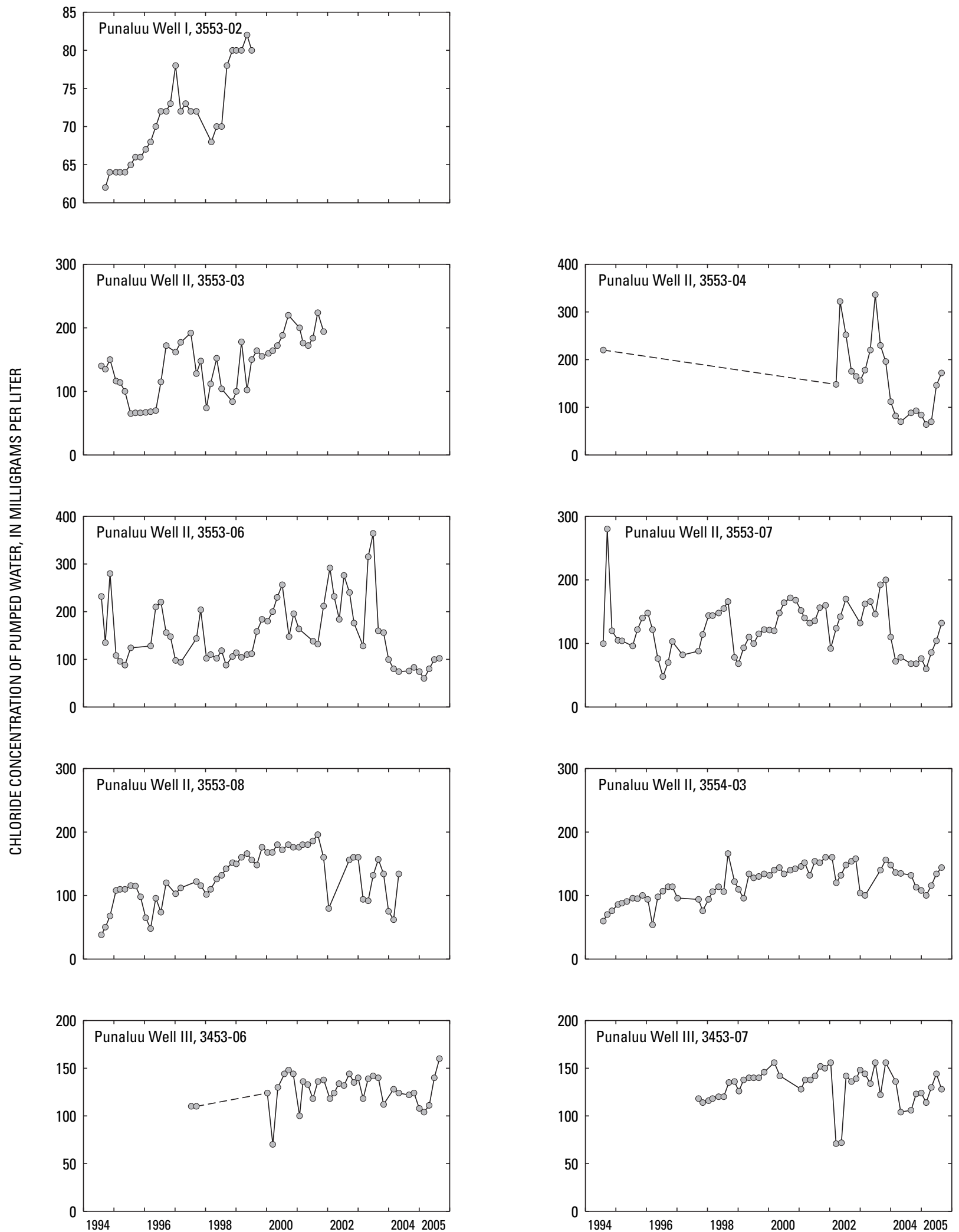

Figure 49. Chloride concentration of pumped water from Punaluu well fields I, II, and III, Oahu, Hawaii. Consecutive data points separated by more than one year are connected by a dashed line. Data from Honolulu Board of Water Supply. 
Above a stream-channel altitude of $25 \mathrm{ft}$ and below the area where dike-impounded water discharges directly to the stream, Punaluu Stream may be hydraulically connected to shallow ground water in the sedimentary deposits. Whether a continuous zone of saturation exists between the ground water in the sedimentary deposits (above an altitude of $25 \mathrm{ft}$ ) and underlying volcanic rocks is unknown. If a continuous zone of saturation does exist, ground-water withdrawal from the volcanic rocks could potentially reduce streamflow in this area by enhancing recharge from the stream to the sedimentary deposits. The likelihood that a continuous zone of saturation exists probably decreases with increasing altitude.

\section{Water-Level Variations Caused by Withdrawal}

Two main production well fields currently are operated in the Punaluu area (Punaluu II and III well fields) (fig. 3). During 2000-2002, combined withdrawal from the Punaluu II and III well fields averaged about $6.5 \mathrm{Mgal} / \mathrm{d}$, although withdrawals were later reduced and averaged about $2.4 \mathrm{Mgal} / \mathrm{d}$ in 2004 (fig. 40). Reduced withdrawals from the well fields will tend to reduce the magnitude of possible reductions in streamflow caused by withdrawal. On the basis of measured water-level variations in monitoring wells, withdrawals west of Punaluu Stream can cause ground-water-level declines to the east of the stream and, therefore, also beneath the stream.

During 2005, water levels in several monitoring wells were measured to determine the extent of water-level declines associated with withdrawal from Punaluu well fields II and III. A qualitative assessment of the effects of withdrawal on water levels can be made by comparing water-level variations to the timing of when production wells were turned on or off. Water levels in wells in the Punaluu area commonly are affected by ocean tides. Because the magnitude of water-level variations associated with ocean tides is similar in magnitude to the water-level declines associated with withdrawals, the waterlevel declines are obscured by tidal variations (figs. 45-48). Water-level variations associated with ocean tides were removed from the water-level records by least-squared-error fits of six main tidal components $\left(\mathrm{K}_{1}, \mathrm{O}_{1}, \mathrm{Q}_{1}, \mathrm{M}_{2}, \mathrm{~N}_{2}\right.$, and $\left.\mathrm{S}_{2}\right)$ to the water-level records. The resulting water-level records with tidal variations removed reveal the presence of waterlevel declines associated with withdrawal (figs. 45-48).

Withdrawals from Punaluu III cause short-term (less than 1 day) water-level variations of a few tenths of a foot in Punaluu VA (3454-01) (fig. 48), which is about 2,800 ft from the Punaluu III wells. Withdrawals from Punaluu II also appear to cause short-term water-level variations up to about $0.2 \mathrm{ft}$ in Punaluu VA. Wells in the Punaluu II well field are 6,000-7,600 ft away from Punaluu VA.

Withdrawals from Punaluu III cause short-term waterlevel variations of up to $0.2 \mathrm{ft}$ in well 3453-05 (fig. 45), which is about 3,300-3,500 ft from the Punaluu III wells. Withdrawals from Punaluu II also appear to cause short-term waterlevel variations, about $0.1 \mathrm{ft}$ in magnitude, in well 3453-05.
Wells in the Punaluu II well field are 4,200-6,700 ft away from well 3453-05. Water-level variations in well 3453-05 caused by withdrawals from Punaluu II and III are slightly smaller in magnitude than water-level variations in Punaluu VA. Wells 3453-05 and Punaluu VA are about the same distance from the production wells. Thus, the greater water-level declines measured in Punaluu VA may reflect (1) a low-permeability valley-fill barrier that partially penetrates the aquifer and that separates the production wells and well 3453-05, or (2) anisotropy or differences in the permeability of the rocks between the monitoring and production wells.

Withdrawals from Punaluu II and III also appear to affect water levels in Makalii well 3 (3453-13) (fig. 47), although to a slightly smaller extent than in well 3453-05. Punaluu II wells are 4,900-7,400 ft away from Makalii well 3, and Punaluu III wells are about 2,100-2,400 ft from Makalii well 3. Both Makalii well 3 and well 3453-05 are on the opposite side of Punaluu Stream, relative to the Punaluu II and III wells.

Of the monitoring wells used in this study, Makalii well 1 (3452-02) is farthest from the Punaluu II and III wells. Punaluu II wells are 6,500-9,000 ft away from Makalii well 1, and Punaluu III wells are about 4,600-4,800 ft from Makalii well 1 . Withdrawals from these production wells may affect long-term water levels in Makalii well 1, although shortterm effects, if they exist, appear to be small (less than $0.1 \mathrm{ft}$ ) (fig. 46).

Water levels in the volcanic-rock aquifer beneath and adjacent to Punaluu Stream are affected by withdrawals from the Punaluu II and III wells. On a short-term basis, flow in Punaluu Stream may not be affected measurably by withdrawals from the Punaluu II and III wells because the low-permeability sedimentary deposits separating the stream and the underlying volcanic rocks impede the spread of water-level declines to the stream. However, if a continuous zone of saturation exists between the stream and the underlying volcanic rocks, long-term water-level declines caused by withdrawals from the Punaluu II and III wells will ultimately extend to the stream and cause a reduction of ground-water discharge to the stream. The magnitude of streamflow reduction is unknown, but may be immeasurable, depending on the rate of withdrawal, because of the presence of low-permeability sedimentary deposits separating the stream and underlying volcanic rocks. The spread of the cone of depression from the west side of Punaluu Stream to the east side indicates that groundwater discharge in areas east of Punaluu Stream are affected by withdrawals from Punaluu II and III. Thus, long-term ground-water withdrawal from the existing well fields will have a regional effect on ground-water-discharge reduction that is not limited to Punaluu Stream.

Near a stream altitude of about $10 \mathrm{ft}$ in Punaluu Stream, discharge and stream-stage measurements indicate that a decline in stage of about $0.01 \mathrm{ft}$ corresponds to about a $0.6 \mathrm{ft}^{3} / \mathrm{s}$ decline in streamflow within a discharge range of 15 to $57 \mathrm{ft}^{3} / \mathrm{s}$ (fig. 50). Thus, if ground-water withdrawal causes a $0.01-\mathrm{ft}$ decline in stream stage near an altitude of $10 \mathrm{ft}$, streamflow 
would be reduced by about $0.6 \mathrm{ft}^{3} / \mathrm{s}(0.39 \mathrm{Mgal} / \mathrm{d})$. Although ground-water withdrawals may reduce ground-water levels in the volcanic-rock aquifer by a few tenths of a foot near Punaluu Stream, the magnitudes of the water-level declines in the sedimentary deposits and in Punaluu Stream caused by withdrawals are uncertain.

\section{Hydrologic Effect of Dikes}

The presence of high water levels and streamflow gains in the mountainous interior areas are indicative of the presence of low-permeability dikes that impede the inland spreading of effects associated with coastal ground-water withdrawals. In the mountainous interior area, Punaluu Stream gains water directly in the main stream channel where the water level in the dike-impounded water body is greater than the stream-channel altitude. Punaluu Stream also receives water from tributaries that gain ground-water discharge from the dike-impounded water body. Ground-water withdrawals near the coastal area will cause ground-water levels to decline. In the Punaluu area, low-permeability dikes will impede inland spreading of the zone in which water levels decline. For example, simulation results from a numerical ground-waterflow model of the Island of Molokai, Hawaii, indicated that water-level declines caused by withdrawing ground water from central Molokai do not spread to perennial streams in northeast Molokai because of the presence of low-permeability dikes between the well and perennial streams (Oki, 1997).

The potential long-term effects of ground-water withdrawal on ground-water discharge to Punaluu Stream at high altitudes is dependent on the permeability of the dikes and other volcanic rocks that exist between the withdrawal wells and sites of discharge to Punaluu Stream or tributaries. If the permeability of the dikes and rocks between the withdrawal wells and sites of discharge to the stream is low (relative to the permeability of the coastal sediments or the sedimentary deposits separating the volcanic rocks and the stream at altitudes below $25 \mathrm{ft}$ ), then the reduction in ground-water discharge from the dike-impounded water body to Punaluu Stream will likely be small. However, if the effect on dikeimpounded water is small, then the effect on streamflow below an altitude of $25 \mathrm{ft}$ or coastal discharge to the ocean will tend to be larger.

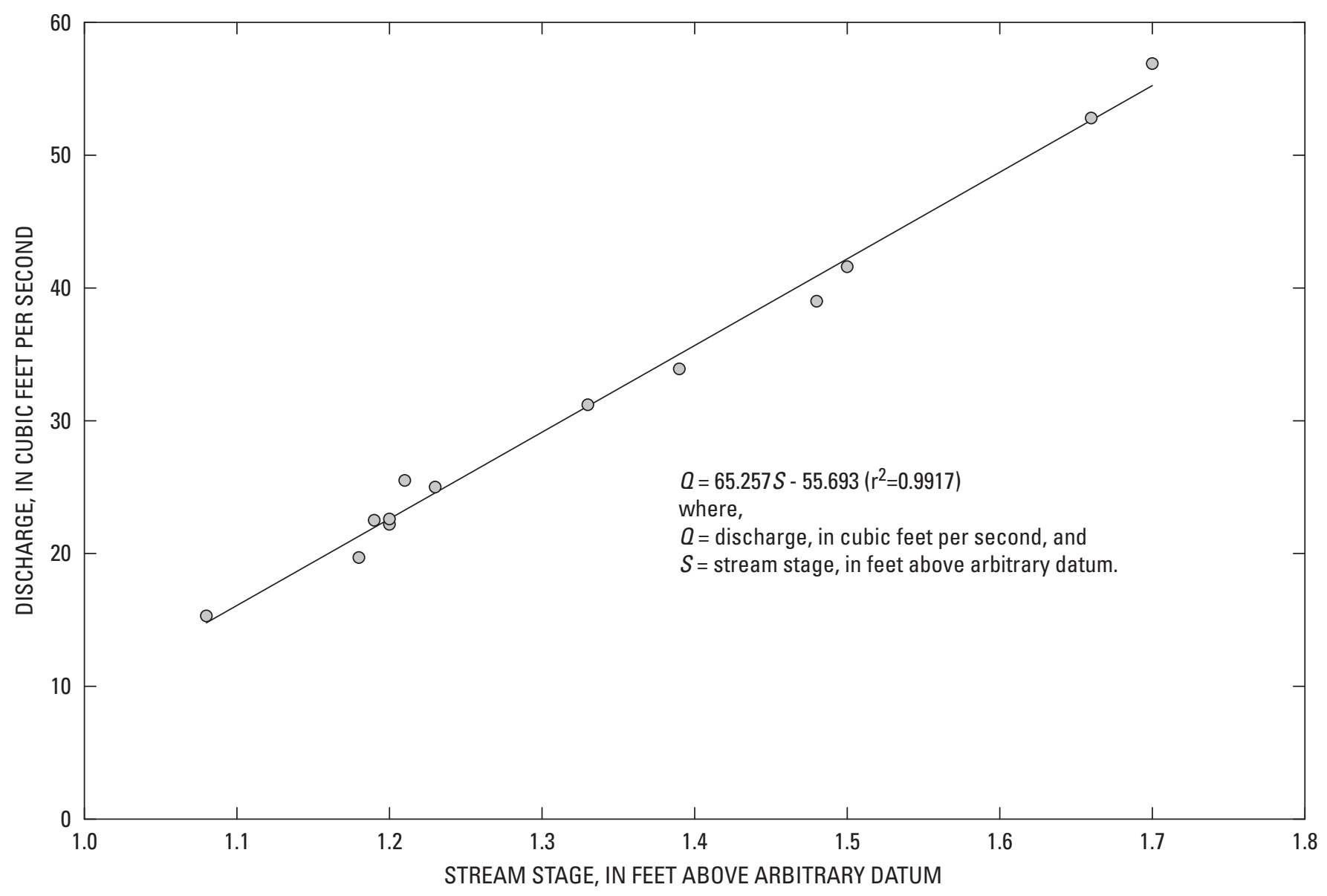

Figure 50. Stage-discharge relation for Punaluu Stream near an altitude of 10 feet, Oahu, Hawaii, 2004-2005. 
Double-mass curves (Searcy and Hardison, 1960) of cumulative flow at two gaging stations can sometimes provide an indication of changes in flow conditions at one of the gaging stations relative to the other, although double-mass curves for Punaluu Stream (station 16303003) and nearby index stations do not indicate an unequivocal or marked change in base-flow conditions after 1968, when ground-water withdrawals in the Punaluu area increased. A change in slope of the double-mass curve between base flow at gaging station 16303003 and other index stations on Oahu, where base flow was not affected by ground-water withdrawal in the Punaluu area, could reflect a change in base flow at station 16303003 in response to ground-water withdrawal in the area. Doublemass curves of base flow at gaging station 16303003 and index gaging stations on Kalihi Stream (16229000) and North Fork Kaukonahua Stream (16200000), however, do not appear to reflect any consistent long-term changes associated with increased withdrawals in the Punaluu area during the late 1960s (fig. 51). On the basis of a least-squared-error fit of two line segments to the data, with a break point in 1968 when ground-water withdrawal in the Punaluu area increased (fig. 40), the slope of the double-mass curve increases after 1968 using station 16200000 as an index station and decreases using station 16229000 as an index station. These slope changes indicate that base flow at station 16303003 decreased, relative to station 16200000, after 1968 and base flow at station 16303003 increased, relative to station 16229000, after 1968. Thus, use of double-mass curves to evaluate changes in baseflow conditions at station 16303003 is inconclusive.

\section{Approaches to Quantify Streamflow Reduction}

The data collected for this study indicate the potential for ground-water withdrawal from existing wells to reduce flow in Punaluu Stream. Proper management and protection of instream uses may require a better understanding of the effects of ground-water withdrawal on streamflow, which can be quantified using numerical or analytical ground-water models. Numerical ground-water-flow models represent the best available tools for evaluating the effects of ground-water withdrawal on flow in Punaluu Stream and discharge of ground water to the nearshore environment. A properly constructed numerical ground-water-flow model can account for the geometry and boundaries of the flow system and the spatial distributions of recharge, withdrawals, and hydraulic characteristics of the rocks. Development of a numerical ground-water-flow model for the Punaluu area was beyond the scope of this study, but could be useful for the management and protection of the water resources in the Punaluu area.

In general, analytical models do not account for complex boundary conditions and aquifer heterogeneities that control the interaction between ground water and surface water. Commonly used analytical solutions (see for example Jenkins, 1970; Spalding and Khaleel, 1991; Sophocleous and others, 1995) assume that the stream forms a straight-line boundary that represents the only steady-state source of water to a well. Some analytical solutions (Sophocleous and others, 1995) attempt to account for a low-permeability streambed layer and can be used to estimate streamflow reduction in a finite reach of an infinitely long stream. The main limitation of this approach is that an infinitely long stream reach is needed to account for 100 percent of the water withdrawn by a production well, and an unrealistically long stream reach may be needed to account for even 50 percent of the water withdrawn by the well.

\section{Summary and Conclusions}

The surface- and ground-water resources of Punaluu Stream Valley of northeast Oahu, Hawaii, have been and continue to be important for cultural, domestic, agricultural, recreational, and aesthetic purposes. Punaluu Stream provides water for traditional and customary Hawaiian practices, irrigation of agricultural crops and ornamental plants, livestock, and aquaculture operations. In addition, Punaluu Stream provides habitat for native aquatic species. Flow in Punaluu Stream is reduced by the direct diversion of water for off-stream uses and possibly by the withdrawal of ground water near the stream.

Punaluu Stream flows perennially, receiving flow from numerous tributaries, many of which also are perennial. Punaluu Stream flows perennially because rain falls frequently in the area and ground water discharges to the stream. Punaluu Stream flows perennially during periods of no rainfall because of ground-water discharge to the stream (base flow). During water years 1955-2004, the minimum daily mean flow recorded in Punaluu Stream at an altitude of about $210 \mathrm{ft}$ (gaging station 16303003) upstream from all diversions was $8.0 \mathrm{ft}^{3} / \mathrm{s}$.

Punaluu Ditch was constructed in the 1920s and diverts water from Punaluu Stream at an altitude of about $210 \mathrm{ft}$. During the period 1995-2004, mean discharge in Punaluu Ditch measured at gaging station 16302000 was $10.8 \mathrm{ft}^{3} / \mathrm{s}$, representing about 49 percent of the mean discharge available in Punaluu Stream measured by gaging station 16303003 during the period. During 1995-2004, daily mean discharge in the Ditch was less than $2 \mathrm{ft}^{3} / \mathrm{s}$ about 0.3 percent of the time. The median discharge in Punaluu Ditch during 1995-2004 was $11 \mathrm{ft}^{3} / \mathrm{s}$, whereas the $\mathrm{Q}_{95}$ discharge was $5.5 \mathrm{ft}^{3} / \mathrm{s}$.

During the recent period 1995-2004, the $\mathrm{Q}_{50}$ and $\mathrm{Q}_{95}$ discharges measured immediately upstream from the Punaluu Ditch diversion intake (gaging station 16303003), respectively, were 18 and $13 \mathrm{ft}^{3} / \mathrm{s}$, whereas the $\mathrm{Q}_{50}$ and $\mathrm{Q}_{95}$ discharges measured immediately downstream from the diversion intake (gaging station 16303000), respectively, were 7.0 and $1.3 \mathrm{ft}^{3} / \mathrm{s}$. Thus, near an altitude of $210 \mathrm{ft}$, diversion of surface water by the Punaluu Ditch caused the $\mathrm{Q}_{50}$ discharge in Punaluu Stream to be reduced to 39 percent of the natural $\mathrm{Q}_{50}$ discharge, and the $\mathrm{Q}_{95}$ discharge was reduced to 10 percent of the natural 

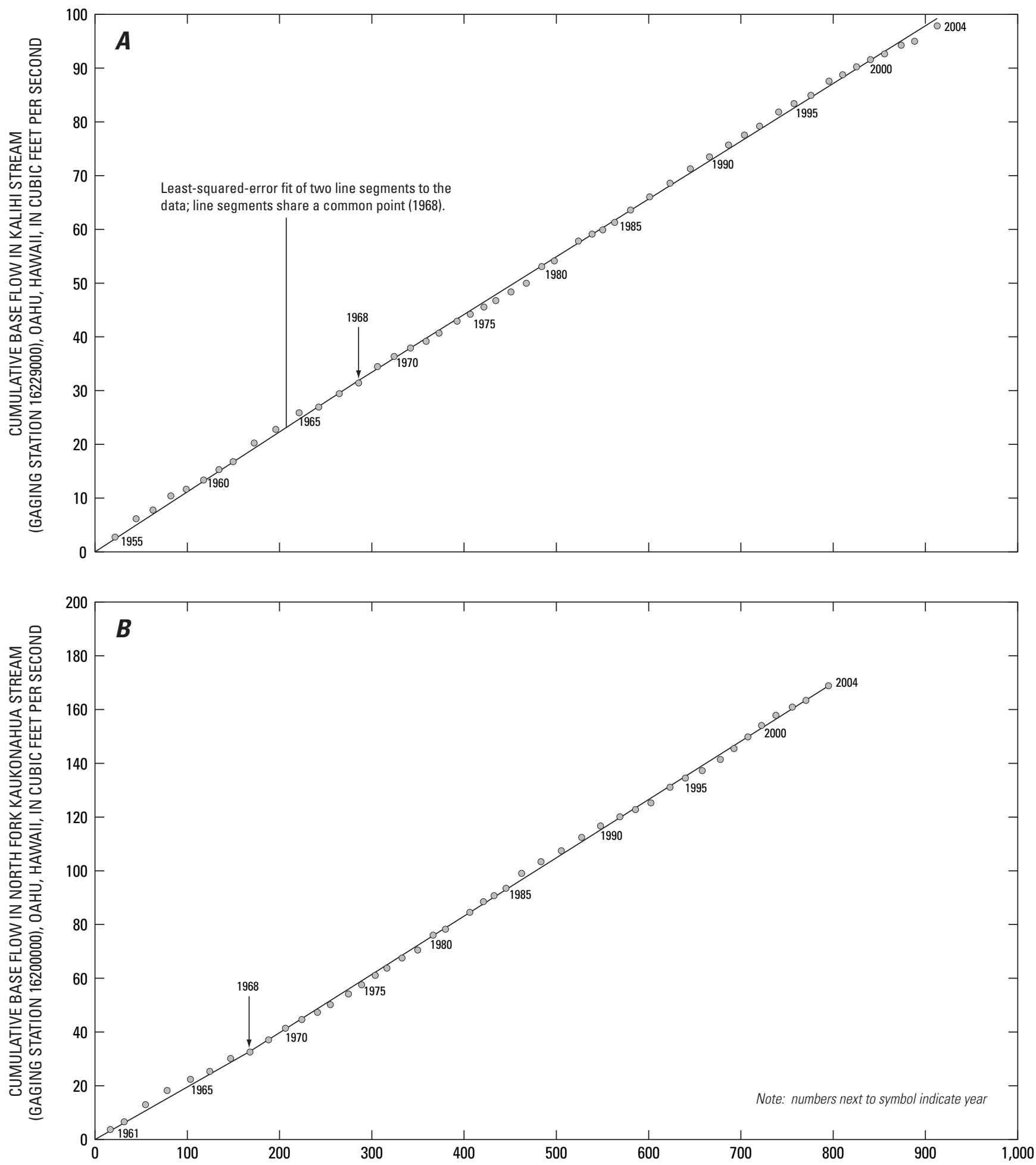

CUMULATIVE BASE FLOW IN PUNALUU STREAM (GAGING STATION 16303003), OAHU, HAWAII, IN CUBIC FEET PER SECOND

Figure 51. Double-mass curves of cumulative base flows in Punaluu Stream (gaging station 16303003) and (A) Kalihi Stream (gaging station 16229000), (B) North Fork Kaukonahua Stream (gaging station 16200000), Oahu, Hawaii. Base flows were estimated using the base-flow separation model of Wahl and Wahl (1995) and N-values of 4, 4 and 5 respectively for gaging stations 16303003,16200000 , and 16229000 . 
value. The effects of the Punaluu Ditch diversion on flow in Punaluu Stream decrease in a downstream direction, mainly because of the compensating effects of tributary inflows and ditch return flows. For recent diverted conditions, the $\mathrm{Q}_{50}$ discharges in Punaluu Stream at altitudes of 140, 100, 40, and $10 \mathrm{ft}$, respectively, were $41,44,48$, and 82 percent of the natural $\mathrm{Q}_{50}$ discharges at these altitudes, and the $\mathrm{Q}_{95}$ discharges in Punaluu Stream at altitudes of 140, 100, 40, and $10 \mathrm{ft}$, respectively, were $11,16,17$, and 69 percent of the natural $Q_{95}$ discharges at these altitudes. Lower flows in Punaluu Stream are affected by the diversion of surface water to a relatively greater extent than higher flows.

Changes in streamflow will affect the quantity and quality of physical habitat used by native stream fauna. The Instream Flow Incremental Methodology (IFIM) was used in this study to quantify the effects of incremental changes in streamflow on physical habitat. The Physical Habitat Simulation System (PHABSIM) approach was used to evaluate the effects of different diversion scenarios on physical habitat in Punaluu Stream. Habitat data were collected at four study reaches, each about $300 \mathrm{ft}$ in length, located at stream altitudes of 10, 40, 100, and $200 \mathrm{ft}$ in Punaluu Stream.

Habitat-suitability criteria developed for streams in northeast Maui were used to determine the effects of incremental changes in streamflow on physical habitat, in terms of weighted usable area (WUA), for selected native species in Punaluu Stream. For this study, the dominant substrate category and dimensionless Froude number were used to characterize habitat suitability. In general, the relations between the quantity of suitable physical habitat and discharge increase monotonically from a discharge of zero to the median natural discharge, although the relation for Awaous guamensis (oopu nakea) for the reach at an altitude of $40 \mathrm{ft}$ indicates a maximum habitat at a discharge significantly below the median natural discharge. The relations between WUA and discharge are steepest between discharge rates of zero and a few cubic feet per second, which indicates that the rate of increase in WUA is greatest as discharge increases from zero to a few cubic feet per second (and the rate of decrease in WUA is greatest as discharge decreases from a few cubic feet per second to zero).

Habitat-duration curves were developed for Neritina granosa (hihiwai) and Awaous guamensis (oopu nakea) at the four study reaches for low-flow conditions (less than median discharge). At stream altitudes of $40 \mathrm{ft}$ and higher, habitatduration curves for recent diverted-flow conditions generally are steeper than habitat-duration curves for natural-flow conditions and for constant diversion rates of up to $10 \mathrm{ft}^{3} / \mathrm{s}$, indicating greatest habitat variability for recent diverted-flow conditions. Because a substantial amount (several cubic feet per second) of diverted water is returned to Punaluu Stream between altitudes of about 15 and $35 \mathrm{ft}$, the habitat-duration curve for recent diverted-flow conditions at an altitude of $10 \mathrm{ft}$ is flatter than it would be if no water were returned to the stream above $10 \mathrm{ft}$.

The effects of different diversion conditions on WUA for Neritina granosa and Awaous guamensis were evaluated by determining the average number of days per year for which WUA values are less than a specified reference value (during periods when discharge is less than or equal to the median natural discharge). For recent diverted conditions (19952004), the average number of days per year that WUA values are less than 50 or 75 percent of the WUA value at median natural discharge generally (1) decreases in a downstream direction, reflecting the effects of tributary inflows and ditch return flows, (2) is less than the corresponding number of days for constant diversion rates greater than about $4-5 \mathrm{ft}^{3} / \mathrm{s}$ at a stream altitude of $10 \mathrm{ft}$, and (3) is greater than the corresponding number of days for a constant diversion rate of $10 \mathrm{ft}^{3} / \mathrm{s}$ at stream altitudes of 40, 100, and $140 \mathrm{ft}$. The number of days that WUA values are less than 75 percent of the WUA value at median natural discharge generally increases substantially for constant diversion rates exceeding about $4-5 \mathrm{ft}^{3} / \mathrm{s}$.

Stream temperature is a factor that potentially could affect the abundance and distribution of native aquatic species. During June 2004 to July 2005, daily mean temperatures in Punaluu Stream ranged from $18.6^{\circ} \mathrm{C}$ to $23.0^{\circ} \mathrm{C}$. Stream temperatures immediately upstream and downstream from the diversion intake do not indicate a significant change in temperature caused by a reduction in flow. However, stream temperatures generally increase in a downstream direction. During the months of June through September, the daily mean temperature at an altitude of $10 \mathrm{ft}$ is about $1^{\circ} \mathrm{C}$ to $1.75^{\circ} \mathrm{C}$ warmer than at an altitude of $210 \mathrm{ft}$, whereas during the months of December through March, the temperature at an altitude of $10 \mathrm{ft}$ is about $0.5^{\circ} \mathrm{C}$ to $1^{\circ} \mathrm{C}$ warmer than at an altitude of $210 \mathrm{ft}$. Temperatures in Punaluu Stream vary because of diurnal variations in energy received in the valley. Measured daily maximum temperatures did not exceed $25^{\circ} \mathrm{C}$ and daily minimum temperatures did not drop below $17.5^{\circ} \mathrm{C}$ at any of the study sites. At all of the study sites, daily maximum temperatures remained below the upper-lethal-temperature limits for native aquatic species.

Fresh ground water in the study area is found mainly as dike-impounded water and as a freshwater lens, with smaller amounts possibly occurring in perched systems. Within the study area, the main ground-water-flow system consists of dike-impounded water inland from the coast that may transition to a freshwater lens in dike-free volcanic rocks near the coast. The presence of springs and perennially flowing tributaries indicate that water levels in the dike-impounded ground-water system probably exceed $600 \mathrm{ft}$ above mean sea level in inland areas. Water levels measured in wells generally are less than $25 \mathrm{ft}$ above mean sea level and are less than $10 \mathrm{ft}$ above mean sea level in wells within about 1,500 ft from the coast and southeast of Punaluu Stream.

Two main well fields currently are in operation in the Punaluu area. During 2000-2002, combined withdrawal from these well fields averaged about $6.5 \mathrm{Mgal} / \mathrm{d}$. Withdrawals from these well fields were reduced toward the end of 2003, and during 2004, combined withdrawal averaged about $2.4 \mathrm{Mgal} / \mathrm{d}$. 
Ground-water withdrawals may affect streamflow in reaches where the ground-water body is hydraulically connected to the stream or downstream from these reaches. On the basis of (1) measured water levels in wells, relative to stream-channel altitudes, and (2) discharge measurements indicating where the stream commonly gains water, Punaluu Stream is likely connected to the main ground-water body below an altitude of about $25 \mathrm{ft}$ and in inland areas (above altitudes of at least $210 \mathrm{ft}$ ) where the stream gains water from the dike-impounded ground-water body. Below an altitude of $25 \mathrm{ft}$, the sedimentary deposits in the stream channel likely are saturated above sea level because ground water discharges into Punaluu Stream. Punaluu Stream can gain water from the volcanic rocks where the hydraulic head, as measured by water level, in the volcanic rocks is greater than the streamchannel altitude.

During 2005, water levels in several monitoring wells were measured to determine the extent of the water-level declines associated with withdrawal from the main Punaluu well fields. On the basis of the measured water-level variations in monitoring wells, withdrawals (at 2005 rates) west of Punaluu Stream can cause ground-water-level declines of a few tenths of a foot to the east of the stream. Thus, water levels in the volcanic-rock aquifer beneath and adjacent to Punaluu Stream are affected by withdrawals from the main Punaluu well fields. On a short-term basis, flow in Punaluu Stream may not be affected measurably by withdrawals from the Punaluu II and III wells because the low-permeability sedimentary deposits separating the stream and the underlying volcanic rocks impede the spread of water-level declines to the stream. However, if a continuous zone of saturation exists between the stream and the underlying volcanic rocks, long-term water-level declines caused by withdrawals from the Punaluu II and III wells will ultimately extend to the stream and cause a reduction of ground-water discharge to the stream. The magnitude of streamflow reduction is unknown, but may be immeasurable, depending on the rate of withdrawal, because of the presence of low-permeability sedimentary deposits separating the stream and underlying volcanic rocks.

Additional studies that would lead to a better understanding of the distribution and abundance of native species in Punaluu Stream include studies related to (1) water quality and contaminants in bed sediment and fish tissue, (2) conditions in the estuary, and (3) recruitment. Establishing habitat-suitability criteria specifically for Punaluu Stream would lead to an improved understanding of the effects of diverting water from the stream on suitable habitat. In addition, direct measurement of WUA over a broader range of flows would preclude the need to use modeling techniques to extrapolate measured velocities, depths, and habitat. Development of a numerical ground-water-flow model would provide a tool to quantify the effects of ground-water withdrawal on flow in Punaluu Stream.

\section{References Cited}

Allan, J.D., 2004, Landscapes and riverscapes: the influence of land use on stream ecosystems: Annual Review of Ecology, Evolution, and Systematics, v. 35, p. 257-284.

Blumenstock, D.I., and Price, Saul, 1967, Climate of Hawaii, in Climates of the States, no. 60-51, Climatography of the United States: Washington, D.C., U.S. Department of Commerce.

Bovee, K.D., 1982, A guide to stream habitat analysis using the instream flow incremental methodology: Instream Flow Information Paper No. 12, U.S. Fish and Wildlife Service, Office of Biological Services, FWS/OBS-82/26, 248 p.

Bovee, K.D., 1986, Development and evaluation of habitat suitability criteria for use in the Instream Flow Incremental Methodology: Instream Flow Information Paper No. 21, U.S. Fish and Wildlife Service, Biological Report 86, no. 7, $235 \mathrm{p}$.

Bovee, K.D., 1997, Data collection procedures for the physical habitat simulation system: U.S. Geological Survey, Biological Resources Division, Mid-Continent Ecological Science Center, Fort Collins, Colo., 146 p.

Bovee, K.D., Lamb, B.L., Bartholow, J.M., Stalnaker, C.B., Taylor, Jonathan, and Henriksen, Jim, 1998, Stream habitat analysis using the instream flow incremental methodology: U.S. Geological Survey, Biological Resources Division Information and Technology Report USGS/BRD-19980004, $131 \mathrm{p}$.

Brasher, A.M., 1997, Life history characteristics of the native Hawaiian stream snail Neritina granosa (hihiwai): Cooperative National Park Resources Studies Unit Hawaii Technical Report 114, 46 p.

Brasher, A.M., 2003, Impacts of human disturbances on biotic communities in Hawaiian streams: BioScience, v. 53, p. 1,052-1,060.

Brasher, A.M., and Anthony, S.S., 2000, Occurrence of organochlorine pesticides in stream bed sediment and fish from selected streams on the Island of Oahu, Hawaii, 1998: U.S. Geological Survey Fact Sheet FS-140-00, 6 p.

Brasher, A.M., and Wolff, R.H., 2004, Relations between land use and organochlorine pesticides, PCBs, and semi-volatile organic compounds in streambed sediment and fish on the Island of Oahu, Hawaii: Archives of Environmental Contamination and Toxicology, v. 46, p. 385-398. 
Brasher, A.M., Wolff, R.H., and Luton, C.D., 2004, Associations among land use, habitat characteristics, and invertebrate community structure in nine streams on the Island of Oahu, Hawaii, 1999-2001: U.S. Geological Survey WaterResources Investigations Report 03-4256, 47 p.

Burkhead, N.M., and Jelks, H.L., 2001, Effects of suspended sediment on the reproductive success of the tricolor shiner, a crevice-spawning minnow: Transactions of the American Fisheries Society, v. 130, p. 959-968.

Chapman, P.M., Wang, Feiyue, Janssen, Colin, Persoone, Guido, and Allen, H.E., 1998, Ecotoxicology of metals in aquatic sediments: binding and release, bioavailability, risk assessment, and remediation: Canadian Journal of Fisheries and Aquatic Sciences, v. 55, p. 2,221-2,243.

Colborn, Theo, and Thayer, Kristina, 2000, Aquatic ecosystems: harbingers of endocrine disruption: Ecological Applications, v. 10, p. 949-957.

Couret, C.L., Jr., 1976, The biology and taxonomy of a freshwater shrimp, Atya bisulcata, Randall, endemic to the Hawaiian Islands: Honolulu, University of Hawaii at Manoa, M.S. Thesis, 168 p.

Cuffney, T.F., Meador, M.R., Porter, S.D., and Gurtz, M.E., 1997, Distribution of fish, benthic invertebrate, and algal communities in relation to physical and chemical conditions, Yakima River Basin, Washington, 1990: U.S. Geological Survey Water-Resources Investigations Report 96-4280, 94 p.

Devick, W.S., 1991, Patterns of introductions of aquatic organisms to Hawaiian freshwater habitats, in Devick, W.S., (ed.), New Directions in Research, Management and Conservation of Hawaiian Freshwater Stream Ecosystems, Proceedings of the 1990 Symposium on Freshwater Stream Biology and Fisheries Management: Hawaii Department of Land and Natural Resources, Division of Aquatic Resources, p. 189-213.

Doell, R.R., and Dalrymple, G.B., 1973, Potassium-argon ages and paleomagnetism of the Waianae and Koolau Volcanic Series, Oahu, Hawaii: Geological Society of America Bulletin, v. 84, no. 4, p. 1,217-1,241.

Dorrance, W.H., and Morgan, F.S., 2000, Sugar islands, the 165-year story of sugar in Hawaii: Mutual Publishing, Honolulu, Hawaii, 259 p.

Dugan, G.L., and Ekern, P.C., 1984, Chemical constituents of

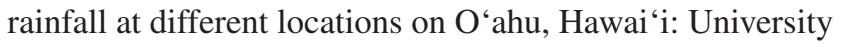
of Hawaii, Water Resources Research Center Technical Report 160, 25 p.
Ego, Kenji, 1956, Life history of freshwater gobies: Proj. No. F-4-R, Freshwater Game Fish Management Research, Department of Land and Natural Resources, State of Hawaii, Honolulu, Hawaii, 23 p.

Fitzsimons, J.M., and Nishimoto, R.T., 1990a, Behavior of gobioid fishes from Hawaiian fresh waters: Invitational Symposium/Workshop on Freshwater Stream biology and Fisheries management, p. 1-22.

Fitzsimons, J.M., and Nishimoto, R.T., 1990b, Territories and site tenacity in males of the Hawaiian stream goby, Lentipes concolor (Pisces: Gobiidae): Ichthyological Exploration of Freshwaters, v. 1, p. 185-189.

Fitzsimons, J.M., Nishimoto, R.T., and Yuen, A.R., 1993, Courtship and territorial behavior in the native Hawaiian stream goby, Sicyopterus stimpsoni: Ichthyological Exploration of Freshwaters, v. 4, p. 1-10.

Font, W.F., 1997a, Improbable colonists: Helminth parasites of freshwater fishes on an oceanic island: Micronesica, v. 30, p. 105-115.

Font, W.F., 1997b, Distribution of helminth parasites of native and introduced stream fishes in Hawaii: Bishop Museum Occasional Papers, v. 49, p. 56-62.

Fontaine, R.A., 1996, Evaluation of the surface-water quantity, surface-water quality, and rainfall data-collection programs in Hawaii, 1994: U.S. Geological Survey Water-Resources Investigations Report 95-4212, 125 p.

Fontaine, R.A., 2003, Availability and distribution of base flow in lower Honokohau Stream, Island of Maui, Hawaii: U.S. Geological Survey Water-Resources Investigations Report 03-4060, 37 p.

Fontaine, R.A., Wong, M.F., and Matsuoka, Iwao, 1992, Estimation of median streamflows at perennial stream sites in Hawaii: U.S. Geological Survey Water-Resources Investigations Report 92-4099, 37 p.

Ford, J.I., 1979, Biology of a Hawaiian fluvial gastropod Neritina granosa Sowerby (Prosobranchia: Neritidae): Honolulu, University of Hawaii, M.S. Thesis, 92 p.

Ford, J.I., and Kinzie, R.A., III, 1982, Life crawls upstream: Natural History, v. 91, p. 61-66.

Giambelluca, T.W., Lau, L.S., Fok, Y.S., and Schroeder, T.A., 1984, Rainfall frequency study for Oahu: State of Hawaii, Department of Land and Natural Resources, Division of Water and Land Development, Report R73, 232 p. 
Giambelluca, T.W., Nullet, M.A., and Schroeder, T.A., 1986, Rainfall atlas of Hawai 'i: State of Hawaii, Department of Land and Natural Resources, Report R76, 267 p.

Gingerich, S.B., and Oki, D.S., 2000, Ground water in Hawaii: U.S. Geological Survey Fact Sheet 126-00, 6 p.

Gingerich, S.B., and Wolff, R.H., 2005, Effects of surfacewater diversions on habitat availability for native macrofauna, northeast Maui, Hawaii: U.S. Geological Survey Scientific Investigations Report 2005-5213, 93 p.

Grover, N.C., and Larrison, G.K., 1917, Surface water supply of Hawaii, July 1, 1915, to June 30, 1916: U.S. Geological Survey Water-Supply Paper 445, 224 p.

Handy, E.S.C., Handy, E.G., and Pukui, M.K., 1991, Native planters in old Hawaii: Bishop Museum Press, Honolulu, Hawaii, 676 p.

Hathaway, C.B., 1978, Stream channel modification in Hawaii, Part C: Tolerance of native stream species to observed levels of environmental variability: U.S. Fish and Wildlife Service National Stream Alteration Team, Columbia, Mo., FWS/ OBS-78/18, $59 \mathrm{p}$.

Hawaii Cooperative Park Service Unit, 1990, Hawaii stream assessment: A preliminary appraisal of Hawaii's stream resources: State of Hawaii Department of Land and Natural Resources, Commission on Water Resource Management, Report R84, 294 p.

Higashi, G.R., and Yamamoto, M.N., 1993, Rediscovery of "extinct" Lentipes concolor (Pisces: Gobiidae) on the Island of Oahu, Hawaii: Pacific Science, v. 47, p. 115-117.

Hirsch, R.M., 1982, A comparison of four streamflow record extension techniques: Water Resources Research, v. 18, no. 4, p. 1,081-1,088.

Jenkins, C.T., 1970, Computation of rate and volume of stream depletion by wells: U.S. Geological Survey Techniques of Water-Resources Investigations Book 4, Chapter D1, 17 p.

Kido, M.H., 1996a, Morphological variation in feeding traits of native Hawaiian stream fishes: Pacific Science, v. 50, p. 184-193.

Kido, M.H., 1996b, Diet and food selection in the endemic Hawaiian amphidromous goby, Sicyopterus stimpsoni (Pisces: Gobiidae): Environmental Biology of Fishes, v. 45, p. 199-209.

Kido, M.H., 1997a, Food relations between coexisting native Hawaiian stream fishes: Environmental Biology of Fishes, v. 49 , p. $481-494$.

Kido, M.H., 1997b, Food webs and feeding dynamics of coexisting native Hawaiian stream gobies: Micronesica, v. 30, p. 71-82.
Kido, M.H., Ha, Phyllis, and Kinzie, R.A., III, 1993, Insect introductions and diet changes in an endemic Hawaiian amphidromous goby, Awaous stamineus (Pisces: Gobiidae): Pacific Science, v. 47, p. 43-50.

Kinzie, R.A., III, 1988, Habitat utilization by Hawaiian stream fishes with reference to community structure in oceanic island streams: Environmental Biology of Fishes, v. 22, p. 179-192.

Kinzie, R.A., III, 1990, Species profiles: Life histories and environmental requirements of coastal vertebrates and invertebrates, Pacific Ocean Region; Report 3, Amphidromous macrofauna of island streams: Technical Report EL-89-10, U.S. Army Engineer Waterways Experiment Station, Vicksburg, Miss., 28 p.

Kinzie, R.A., III, and Ford, J.I., 1982, Population biology in small Hawaiian streams: University of Hawaii, Water Resources Research Center Technical Report 147, 60 p.

Klasner, F.L., and Mikami, C.D., 2003, Land use on the Island of Oahu, Hawaii, 1998: U.S. Geological Survey WaterResources Investigations Report 02-4301, 20 p.

Kreeger, Karen, 2000, Down on the fish farm: developing effluent standards for aquaculture: BioScience, v. 50, p. 949-953.

Kunesh, J.F., 1929, Surface water supply of the Island of Oahu, 1909-1928, Supplement to the report of the Honolulu Sewer and Water Commission to the Legislature of the Territory of Hawaii, Fifteenth regular session, 307 p.

Langenheim, V.A.M., and Clague, D.A., 1987, The HawaiianEmperor volcanic chain, part II, stratigraphic framework of volcanic rocks of the Hawaiian Islands, chap. 1 of Decker, R.W., Wright, T.L., and Stauffer, P.H., (eds.), Volcanism in Hawaii: U.S. Geological Survey Professional Paper 1350, v. 1, p. $55-84$.

Lau, E.Y., 1973, Dimorphism and speciation in the Hawaiian freshwater goby genus Lentipes: B.A. Honors Thesis, University of Hawaii at Manoa, Honolulu, Hawaii, 83 p.

Lohman, S.W., 1979, Ground-water hydraulics: U.S. Geological Survey Professional Paper 708, 70 p.

Luton, C.D., Brasher, A.M.D., Durkin, D.C., and Little, Page, 2005, Larval drift of amphidromous shrimp and gobies on the Island of Oahu, Hawaii: Micronesica, v. 38, p. 1-16.

Maciolek, J.A., 1977, Taxonomic status, biology, and distribution of Hawaiian Lentipes, a diadromous goby: Pacific Science, v. 31, p. 355-362. 
Martin, W.F., and Pierce, C.H., 1913, Water resources of Hawaii 1909-1911: U.S. Geological Survey Water-Supply Paper 318, 552 p.

McDowall, R.M., 1988, Diadromy in fishes: Portland, Oregon, Timber Press, $250 \mathrm{p}$.

McDowall, R.M., 1993, Implication of diadromy for the structuring and modeling of riverine fish communities in New Zealand: New Zealand Journal of Marine and Freshwater Research, v. 27, p. 453-462.

McDowall, R.M., 2003, Hawaiian biogeography and the islands' freshwater fish fauna: Journal of Biogeography, v. 30, p. 703-710.

Murty, A.S., 1986, Sublethal effects of pesticides on fish, in Murty, A.S., (ed.), Toxicity of pesticides to fish, v. 2: Boca Raton, Fla., CRC Press, Inc., p. 55-100.

Nico, Leo, 2006, Sarotherodon melanotheron, USGS Nonindigenous Aquatic Species Database, Gainesville, Fla., accessed Feb. 27, 2006, at http://nas.er.usgs.gov/queries/ FactSheet.asp?speciesID=477, Revision Date: 7/23/2004.

Nishimoto, R.T., and Fitzsimons, J.M., 1986, Courtship, territoriality, and coloration in the endemic Hawaiian freshwater goby, Lentipes concolor: Indo-Pacific Fish Biology: Proceedings of the Second International Conference on Indo-Pacific Fishes, p. 811-817.

Nowell, L.H., Capel, P.D., and Dileanis, P.D., 1999, Pesticides in stream sediment and aquatic biota. Distribution, trends, and governing factors. Pesticides in the Hydrologic System series. Boca Raton, Fla., CRC Press, 1,001 p.

Nullet, Dennis, and Sanderson, Marie, 1993, Radiation and energy balances and air temperature, chap. 3 of Sanderson, Marie, (ed.), Prevailing trade winds, weather and climate in Hawai 'i: University of Hawaii Press, p. 37-55.

Oki, D.S., 1997, Geohydrology and numerical simulation of the ground-water flow system of Molokai, Hawaii: U.S. Geological Survey Water-Resources Investigations Report 97-4176, $62 \mathrm{p}$.

Oki, D.S., 2003, Surface water in Hawaii: U.S. Geological Survey Fact Sheet 045-03, 6 p.

Olson, R.M., 1980, Essentials of engineering fluid mechanics: Harper \& Row, Publishers, New York, 583 p.

Pajak, Paul, Wehnes, R.E., Gates, Lawrence, Siegwarth, Gary, Lyons, John, Pitlo, J.M., Holland, R.S., Roseboom, D.P., and Zuckerman, Lawrence, 1994, Agricultural land use and reauthorization of the 1990 Farm Bill: Fisheries, v. 19, p. $22-27$.

Palmer, H.S., 1946, The geology of the Honolulu ground water supply: Honolulu Board of Water Supply, 55 p.
Post, George, 1987, Textbook of fish health: Neptune City, N.J., T.F.H. Publications, Inc, 288 p.

Railsback, S.F., Stauffer, H.B., and Harvey, B.C., 2003, What can habitat preference models tell us? Tests using a virtual trout population: Ecological Applications, v. 13, p. 1,5801,594 .

Randall, J.E., 1987, Introductions of marine fishes to the Hawaiian Islands: Bulletin of Marine Science, v. 4, p. 490-502.

Rantz, S.E., and others, 1982, Measurement and computation of streamflow: volumes 1 and 2: U.S. Geological Survey Water-Supply Paper 2175, $631 \mathrm{p}$.

Ries, K.G., III, 1993, Estimation of low-flow duration discharges in Massachusetts: U.S. Geological Survey OpenFile Report 93-38, 59 p.

R.M. Towill Corporation, 1978, Punaluu Stream study, water rights phase, Oahu, Hawaii: prepared for Board of Water Supply, City and County of Honolulu, January 1979, 39 p.

Ryan, P.A., 1991, Environmental effects of sediment on New Zealand streams: a review: New Zealand Journal of Marine and Freshwater Research, v. 25, p. 207-221.

Sanderson, Marie, 1993, Prevailing trade winds, weather and climate in Hawai 'i, University of Hawaii Press, Honolulu, $126 \mathrm{p}$.

Searcy, J.K., 1959, Flow-duration curves, Manual of hydrology: part 2. Low-flow techniques: U.S. Geological WaterSupply Paper 1542-A, 33 p.

Searcy, J.K., and Hardison, C.H., 1960, Double-mass curves, Manual of hydrology: part 1. General surface-water techniques: U.S. Geological Water-Supply Paper 1541-B, p. 31-66.

Sophocleous, Marios, Koussis, Antonis, Martin, J.L, and Perkins, S.P., 1995, Evaluation of simplified stream-aquifer depletion models for water rights administration: Ground Water, v. 35 , no. 4 , p. 579-588.

Spalding, C.P., and Khaleel, Raziuddin, 1991, An evaluation of analytical solutions to estimate drawdowns and stream depletions by wells: Water Resources Research, v. 27, no. 4, p. 597-609.

State of Hawaii, 1988, Punaluu Stream channel clearing project: investigation of complaint, Punaluu, Koolauloa, Oahu: Department of Land and Natural Resources, Division of Water and Land Development, 12 p. plus attachments.

State of Hawaii, 2004, Hawaii stream survey database: Hawaii Department of Land and Natural Resources, Division of Aquatic Resources: Database accessed May 30, 2004, at http://www.state.hi.us/dlnr/dar/streams/stream_data.htm. 
State of Hawaii, 2005, Hawaii Statewide GIS program: State of Hawaii, Office of Planning, accessed June 13, 2005, at http://www.state.hi.us/dbedt/gis/index.html.

Stearns, H.T., 1939, Geologic map and guide of the Island of Oahu, Hawaii: Hawaii Division of Hydrography, Bulletin 2, 75 p., map scale 1:62,500.

Stearns, H.T., and Vaksvik, K.N., 1935, Geology and groundwater resources of the Island of Oahu, Hawaii: Hawaii Division of Hydrography, Bulletin 1, 479 p.

Takasaki, K.J., Hirashima, G.T., and Lubke, E.R., 1969, Water resources of windward Oahu, Hawaii: U.S. Geological Survey Water-Supply Paper 1894, 119 p.

Takasaki, K.J., and Mink, J.F., 1985, Evaluation of major dikeimpounded ground-water reservoirs, Island of Oahu: U.S. Geological Survey Water-Supply Paper 2217, 77 p.

Territorial Planning Board, 1939, First progress report--an historic inventory of the physical, social and economic and industrial resources of the Territory of Hawaii: Honolulu, Hawaii, Advertiser Publishing Co., 322 p. + supplement.

Timbol, A.S., and Maciolek, J.A., 1978, Stream channel modification in Hawaii. Part A: statewide inventory of streams; habitat factors and associated biota: U.S. Fish and Wildlife Service National Stream Alteration Team, Colombia, Mo., FWS/OBS-78/16, 157 p.

Timbol, A.S., Sutter, A.J., and Parrish, J.D., 1980, Distribution, relative abundance, and stream environment of Lentipes concolor (Gill 1860) and associated fauna in Hawaiian streams: University of Hawaii, Water Resources Research Center Cooperative Report no. 5, 64 p.

Tomihama, M.T., 1972, The biology of Sicydium stimpsoni: Freshwater goby endemic to Hawaii: B.S. Honors Thesis, University of Hawaii at Manoa, Honolulu, Hawaii, 123 p.

U.S. Geological Survey, 2001, PHABSIM for Windowsuser's manual and exercises: Open File Report 01-340, $288 \mathrm{p}$.

U.S. Geological Survey, 2005, USGS National Water-Quality Assessment Data Warehouse, accessed September 7, 2005, at http:// infotrek.er.usgs.gov/nawqa/.

Van Dine, B.L., 1907, The introduction of top-minnows into the Hawaiian Islands: Hawaii Agricultural Experiment Station, Press Bulletin No. 20, 10 p.

Visher, F.N., and Mink, J.F., 1964, Ground-water resources in southern Oahu, Hawaii: U.S. Geological Survey WaterSupply Paper 1778, 133 p.
Vitousek, P.M., Loope, L.L., and Stone, C.P., 1987, Introduced species in Hawaii: biological effects and opportunities for ecological research: Trends in Ecology \& Evolution, v. 2, p. 224-227.

Wahl, K.L., and Wahl, T.L., 1995, Determining the flow of Comal Springs at New Braunfels, Texas: Proceedings of Texas Water '95, A Component Conference of the First International Conference on Water Resources Engineering, American Society of Civil Engineers, August 16-17, 1995, San Antonio, Tex., p. 77-86.

Wentworth, C.K., 1939, The specific gravity of sea water and the Ghyben-Herzberg ratio at Honolulu: Honolulu, Hawaii, University of Hawaii Bulletin, v. 18, no. 8, 24 p.

Wentworth, C.K., 1951, Geology and ground-water resources of the Honolulu-Pearl Harbor area Oahu, Hawaii: Honolulu Board of Water Supply, Honolulu, Hawaii, 111 p.

Wilcox, Carol, 1996, Sugar water: Hawaii's plantation ditches: Honolulu, University of Hawai'i Press, 191 p.

Williams, J.A., and Soroos, R.L., 1973, Evaluation of methods of pumping test analyses for application to Hawaiian aquifers: University of Hawaii, Water Resource Research Center Technical Report 70, 159 p.

Wong, C.S., Capel, P.D., and Nowell, L.H., 2001, Nationalscale, field-based evaluation of the biota-sediment accumulation factor model: Environmental Science and Technology, v. 35, p. 1,709-1,715.

Wood, P.J., and Armitage, P.D., 1997, Biological effects of fine sediment in the lotic environment: Environmental Management, v. 21, p. 203-217.

Yamamoto, M.N., and Tagawa, A.W., 2000, Hawaii's native and exotic freshwater animals: Honolulu, Hawaii, Mutual Publishing, $200 \mathrm{p}$. 


\section{Appendix A.}

Table 1. Discharge measurements made during 2004 and 2005 in Punaluu Ditch and Punaluu Stream and tributaries, Oahu, Hawaii, sorted by date.

Table 2. Discharge measurements made during 2004 and 2005 in Punaluu Ditch and Punaluu Stream and tributaries, Oahu, Hawaii, sorted by site. 
Table 1. Discharge measurements made during 2004 and 2005 in Punaluu Ditch and Punaluu Stream and tributaries, Oahu, Hawaii, sorted by date.

$\left[\mathrm{ft}^{3} / \mathrm{s}\right.$, cubic feet per second; ft, feet]

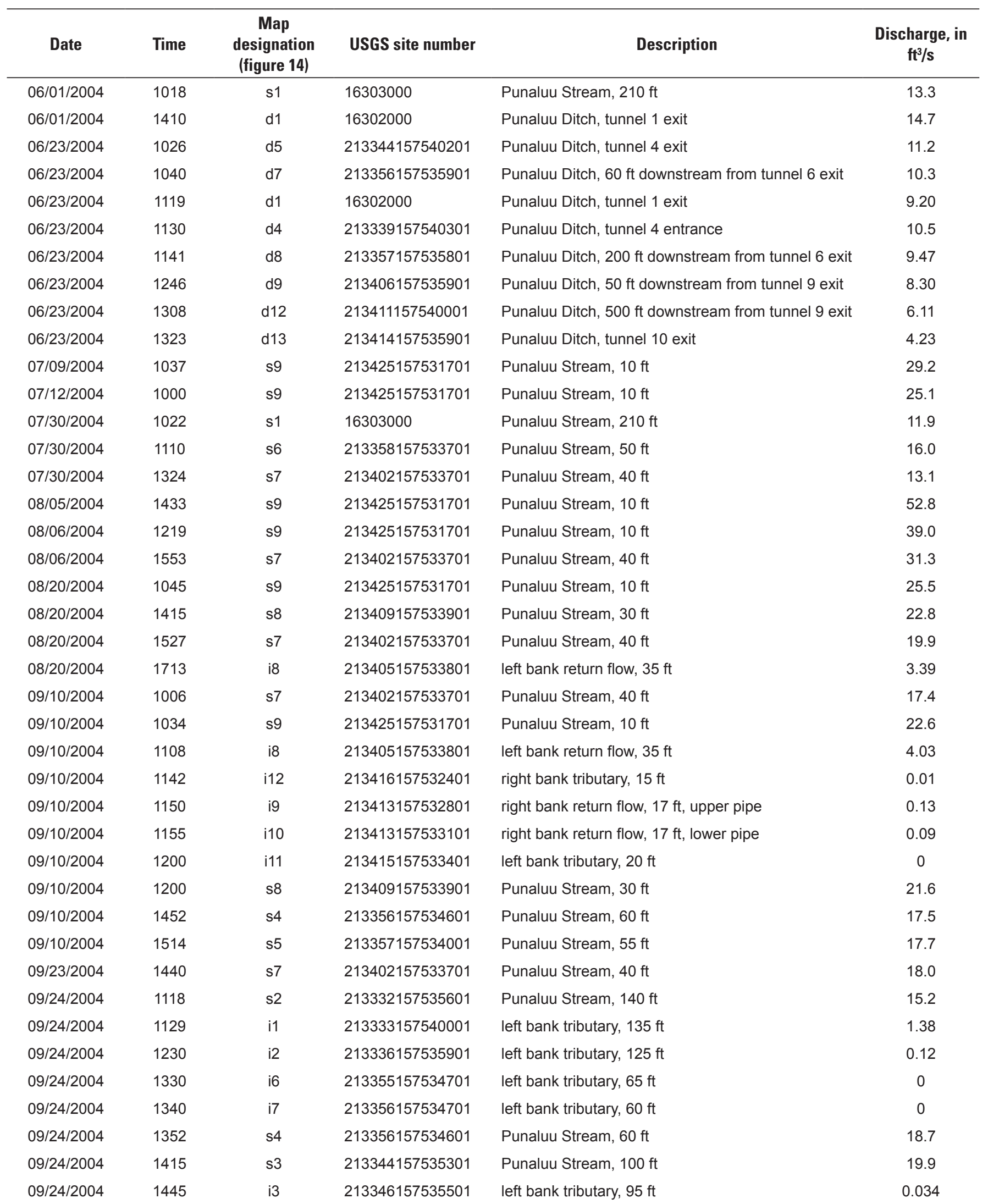


Table 1. Discharge measurements made during 2004 and 2005 in Punaluu Ditch and Punaluu Stream and tributaries, Oahu, Hawaii, sorted by date-Continued.

$\left[\mathrm{ft}^{3} / \mathrm{s}\right.$, cubic feet per second; $\mathrm{ft}$, feet]

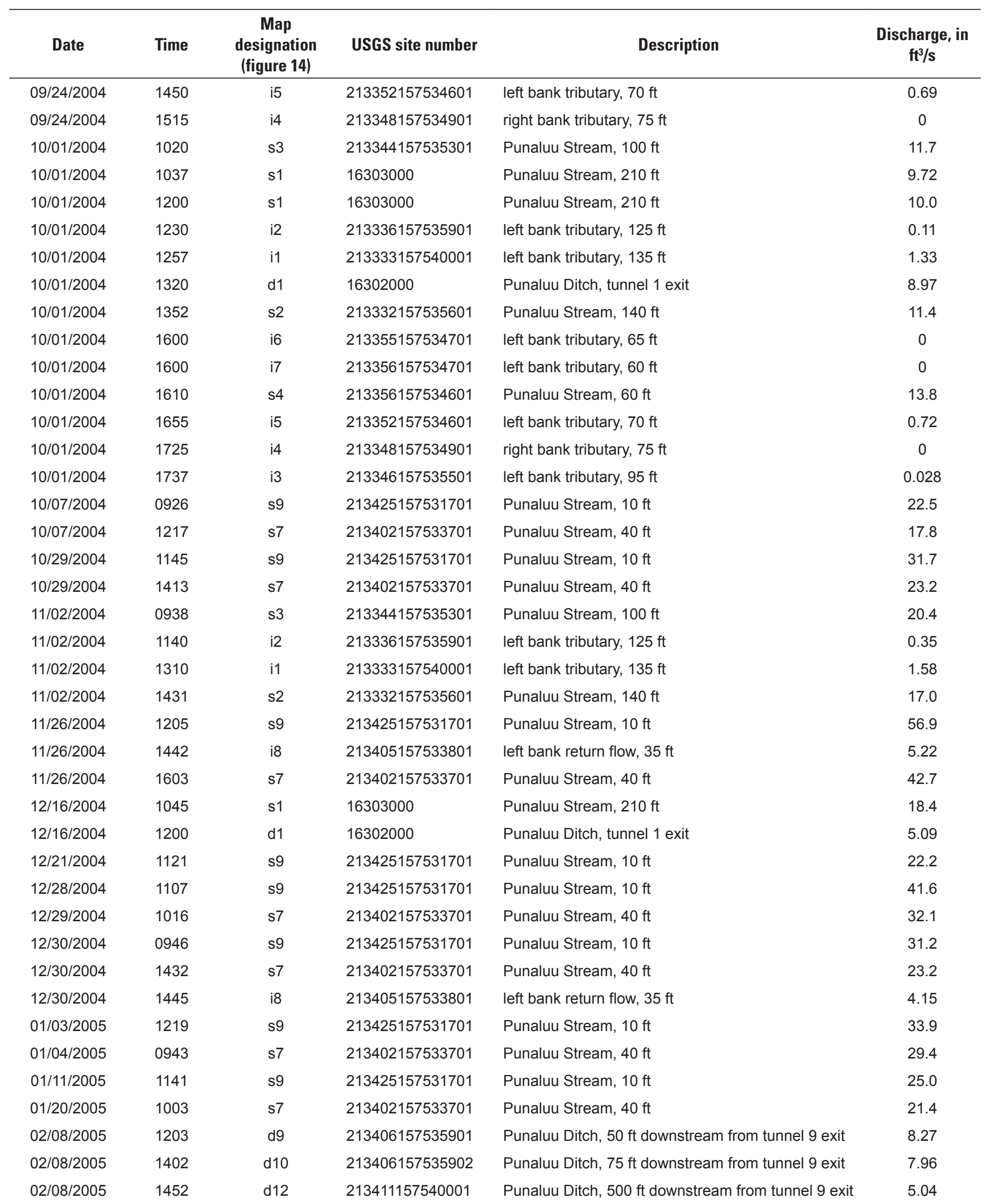


Table 1. Discharge measurements made during 2004 and 2005 in Punaluu Ditch and Punaluu Stream and tributaries, Oahu, Hawaii, sorted by date-Continued.

$\left[\mathrm{ft}^{3} / \mathrm{s}\right.$, cubic feet per second; ft, feet]

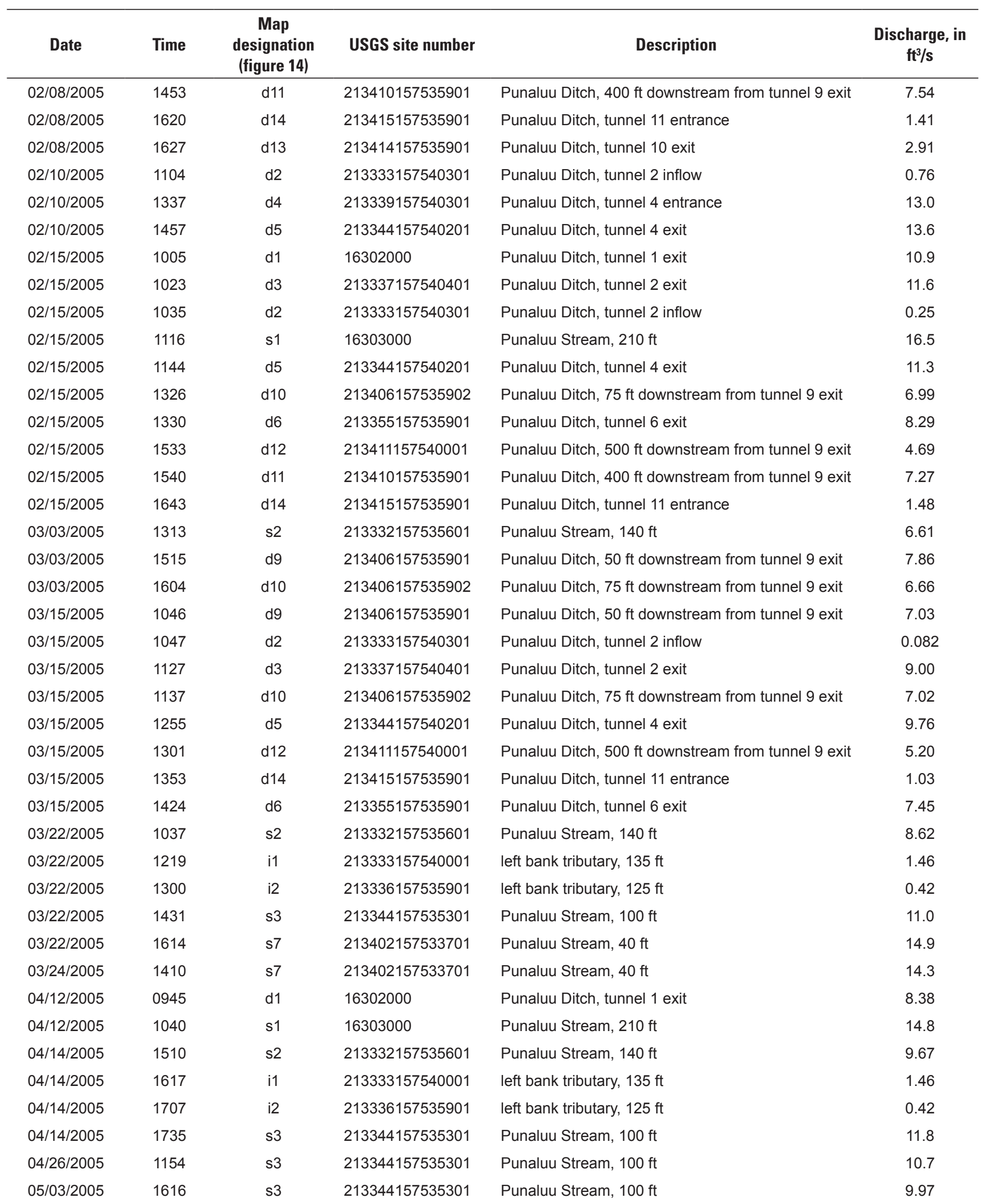


Table 1. Discharge measurements made during 2004 and 2005 in Punaluu Ditch and Punaluu Stream and tributaries, Oahu, Hawaii, sorted by date-Continued.

$\left[\mathrm{ft}^{3} / \mathrm{s}\right.$, cubic feet per second; $\mathrm{ft}$, feet]

\begin{tabular}{|c|c|c|c|c|c|}
\hline Date & Time & $\begin{array}{c}\text { Map } \\
\text { designation } \\
\text { (figure 14) }\end{array}$ & USGS site number & Description & $\begin{array}{c}\text { Discharge, in } \\
\mathrm{ft}^{3} / \mathrm{s}\end{array}$ \\
\hline 05/17/2005 & 1330 & $\mathrm{~s} 2$ & 213332157535601 & Punaluu Stream, $140 \mathrm{ft}$ & 4.12 \\
\hline 05/25/2005 & 1209 & $\mathrm{~s} 2$ & 213332157535601 & Punaluu Stream, $140 \mathrm{ft}$ & 12.6 \\
\hline 05/25/2005 & 1213 & s3 & 213344157535301 & Punaluu Stream, $100 \mathrm{ft}$ & 14.3 \\
\hline 05/25/2005 & 1412 & i2 & 213336157535901 & left bank tributary, $125 \mathrm{ft}$ & 0.34 \\
\hline 05/26/2005 & 1545 & s10 & 213434157531001 & Punaluu Stream, $5 \mathrm{ft}$ & 20.6 \\
\hline 05/26/2005 & 1555 & s9 & 213425157531701 & Punaluu Stream, $10 \mathrm{ft}$ & 19.7 \\
\hline 06/09/2005 & 1050 & s3 & 213344157535301 & Punaluu Stream, $100 \mathrm{ft}$ & 12.1 \\
\hline 06/09/2005 & 1255 & ¡5 & 213352157534601 & left bank tributary, $70 \mathrm{ft}$ & 0.022 \\
\hline 06/09/2005 & 1300 & i4 & 213348157534901 & right bank tributary, $75 \mathrm{ft}$ & 0 \\
\hline 06/09/2005 & 1319 & ¡3 & 213346157535501 & left bank tributary, $95 \mathrm{ft}$ & 0.018 \\
\hline 06/09/2005 & 1400 & i6 & 213355157534701 & left bank tributary, $65 \mathrm{ft}$ & 0 \\
\hline 06/09/2005 & 1412 & i7 & 213356157534701 & left bank tributary, $60 \mathrm{ft}$ & 0.33 \\
\hline 06/09/2005 & 1437 & s7 & 213402157533701 & Punaluu Stream, $40 \mathrm{ft}$ & 12.4 \\
\hline 06/09/2005 & 1512 & s4 & 213356157534601 & Punaluu Stream, $60 \mathrm{ft}$ & 12.5 \\
\hline 06/09/2005 & 1551 & i8 & 213405157533801 & left bank return flow, $35 \mathrm{ft}$ & 0.95 \\
\hline 06/09/2005 & 1618 & i9 & 213413157532801 & right bank return flow, $17 \mathrm{ft}$, upper pipe & 0.59 \\
\hline 06/21/2005 & 1310 & d1 & 16302000 & Punaluu Ditch, tunnel 1 exit & 14.1 \\
\hline 06/22/2005 & 1117 & s9 & 213425157531701 & Punaluu Stream, $10 \mathrm{ft}$ & 21.0 \\
\hline 06/22/2005 & 1132 & s10 & 213434157531001 & Punaluu Stream, $5 \mathrm{ft}$ & 20.4 \\
\hline 06/22/2005 & 1303 & s8 & 213409157533901 & Punaluu Stream, $30 \mathrm{ft}$ & 15.8 \\
\hline 06/22/2005 & 1415 & s7 & 213402157533701 & Punaluu Stream, $40 \mathrm{ft}$ & 10.7 \\
\hline 06/22/2005 & 1435 & i8 & 213405157533801 & left bank return flow, $35 \mathrm{ft}$ & 5.53 \\
\hline 06/22/2005 & 1600 & ¡10 & 213413157533101 & right bank return flow, $17 \mathrm{ft}$, lower pipe & 1.34 \\
\hline 06/22/2005 & 1600 & i9 & 213413157532801 & right bank return flow, $17 \mathrm{ft}$, upper pipe & 0.66 \\
\hline 07/05/2005 & 1155 & s3 & 213344157535301 & Punaluu Stream, $100 \mathrm{ft}$ & 18.0 \\
\hline 08/01/2005 & 1540 & s3 & 213344157535301 & Punaluu Stream, $100 \mathrm{ft}$ & 4.58 \\
\hline 08/01/2005 & 1554 & $\mathrm{~s} 2$ & 213332157535601 & Punaluu Stream, $140 \mathrm{ft}$ & 3.46 \\
\hline 08/04/2005 & 0955 & s3 & 213344157535301 & Punaluu Stream, $100 \mathrm{ft}$ & 9.56 \\
\hline 08/04/2005 & 1016 & i7 & 213356157534701 & left bank tributary, $60 \mathrm{ft}$ & 0.24 \\
\hline 08/04/2005 & 1054 & ¡3 & 213346157535501 & left bank tributary, $95 \mathrm{ft}$ & 0.014 \\
\hline 08/04/2005 & 1100 & s4 & 213356157534601 & Punaluu Stream, $60 \mathrm{ft}$ & 10.2 \\
\hline
\end{tabular}


Table 1. Discharge measurements made during 2004 and 2005 in Punaluu Ditch and Punaluu Stream and tributaries, Oahu, Hawaii, sorted by date-Continued.

$\left[\mathrm{ft}^{3} / \mathrm{s}\right.$, cubic feet per second; $\mathrm{ft}$, feet]

\begin{tabular}{|c|c|c|c|c|c|}
\hline Date & Time & $\begin{array}{c}\text { Map } \\
\text { designation } \\
\text { (figure 14) }\end{array}$ & USGS site number & Description & $\begin{array}{c}\text { Discharge, in } \\
\mathrm{ft}^{3} / \mathrm{s}\end{array}$ \\
\hline 08/04/2005 & 1105 & i4 & 213348157534901 & right bank tributary, $75 \mathrm{ft}$ & 0 \\
\hline 08/04/2005 & 1112 & i5 & 213352157534601 & left bank tributary, $70 \mathrm{ft}$ & 0.035 \\
\hline 08/04/2005 & 1331 & s8 & 213409157533901 & Punaluu Stream, $30 \mathrm{ft}$ & 11.9 \\
\hline 08/04/2005 & 1515 & i9 & 213413157532801 & right bank return flow, $17 \mathrm{ft}$, upper pipe & 0.74 \\
\hline 08/04/2005 & 1530 & ¡10 & 213413157533101 & right bank return flow, $17 \mathrm{ft}$, lower pipe & $2-3$ \\
\hline 08/04/2005 & 1530 & i11 & 213415157533401 & left bank tributary, $20 \mathrm{ft}$ & 0 \\
\hline 08/04/2005 & 1535 & $\mathrm{i} 12$ & 213416157532401 & right bank tributary, $15 \mathrm{ft}$ & 0 \\
\hline
\end{tabular}


Table 2. Discharge measurements made during 2004 and 2005 in Punaluu Ditch and Punaluu Stream and tributaries, Oahu, Hawaii, sorted by site.

$\left[\mathrm{ft}^{3} / \mathrm{s}\right.$, cubic feet per second; ft, feet]

\begin{tabular}{|c|c|c|c|c|c|}
\hline $\begin{array}{c}\text { Map } \\
\text { designation } \\
\text { (figure 14) }\end{array}$ & USGS site number & Description & Date & Time & $\begin{array}{c}\text { Discharge, in } \\
\mathrm{ft}^{3} / \mathrm{s}\end{array}$ \\
\hline d1 & 16302000 & Punaluu Ditch, tunnel 1 exit & $06 / 01 / 2004$ & 1410 & 14.7 \\
\hline $\mathrm{d} 1$ & 16302000 & Punaluu Ditch, tunnel 1 exit & $06 / 23 / 2004$ & 1119 & 9.20 \\
\hline $\mathrm{d} 1$ & 16302000 & Punaluu Ditch, tunnel 1 exit & $12 / 16 / 2004$ & 1200 & 5.09 \\
\hline d1 1 & 16302000 & Punaluu Ditch, tunnel 1 exit & $02 / 15 / 2005$ & 1005 & 10.9 \\
\hline $\mathrm{d} 1$ & 16302000 & Punaluu Ditch, tunnel 1 exit & $04 / 12 / 2005$ & 0945 & 8.38 \\
\hline d1 & 16302000 & Punaluu Ditch, tunnel 1 exit & $06 / 21 / 2005$ & 1310 & 14.1 \\
\hline $\mathrm{d} 2$ & 213333157540301 & Punaluu Ditch, tunnel 2 inflow & 02/10/2005 & 1104 & 0.76 \\
\hline d3 & 213337157540401 & Punaluu Ditch, tunnel 2 exit & $02 / 15 / 2005$ & 1023 & 11.6 \\
\hline d3 & 213337157540401 & Punaluu Ditch, tunnel 2 exit & $03 / 15 / 2005$ & 1127 & 9.00 \\
\hline d4 & 213339157540301 & Punaluu Ditch, tunnel 4 entrance & $06 / 23 / 2004$ & 1130 & 10.5 \\
\hline d4 & 213339157540301 & Punaluu Ditch, tunnel 4 entrance & 02/10/2005 & 1337 & 13.0 \\
\hline d5 & 213344157540201 & Punaluu Ditch, tunnel 4 exit & $06 / 23 / 2004$ & 1026 & 11.2 \\
\hline d5 & 213344157540201 & Punaluu Ditch, tunnel 4 exit & 02/10/2005 & 1457 & 13.6 \\
\hline d5 & 213344157540201 & Punaluu Ditch, tunnel 4 exit & $02 / 15 / 2005$ & 1144 & 11.3 \\
\hline d5 & 213344157540201 & Punaluu Ditch, tunnel 4 exit & $03 / 15 / 2005$ & 1255 & 9.76 \\
\hline d6 & 213355157535901 & Punaluu Ditch, tunnel 6 exit & $02 / 15 / 2005$ & 1330 & 8.29 \\
\hline d9 & 213406157535901 & Punaluu Ditch, $50 \mathrm{ft}$ downstream from tunnel 9 exit & $03 / 15 / 2005$ & 1046 & 7.03 \\
\hline d10 & 213406157535902 & Punaluu Ditch, $75 \mathrm{ft}$ downstream from tunnel 9 exit & 02/08/2005 & 1402 & 7.96 \\
\hline d10 & 213406157535902 & Punaluu Ditch, $75 \mathrm{ft}$ downstream from tunnel 9 exit & $02 / 15 / 2005$ & 1326 & 6.99 \\
\hline $\mathrm{d} 10$ & 213406157535902 & Punaluu Ditch, $75 \mathrm{ft}$ downstream from tunnel 9 exit & $03 / 03 / 2005$ & 1604 & 6.66 \\
\hline d10 & 213406157535902 & Punaluu Ditch, $75 \mathrm{ft}$ downstream from tunnel 9 exit & $03 / 15 / 2005$ & 1137 & 7.02 \\
\hline $\mathrm{d} 11$ & 213410157535901 & Punaluu Ditch, $400 \mathrm{ft}$ downstream from tunnel 9 exit & $02 / 08 / 2005$ & 1453 & 7.54 \\
\hline d11 & 213410157535901 & Punaluu Ditch, $400 \mathrm{ft}$ downstream from tunnel 9 exit & $02 / 15 / 2005$ & 1540 & 7.27 \\
\hline $\mathrm{d} 12$ & 213411157540001 & Punaluu Ditch, $500 \mathrm{ft}$ downstream from tunnel 9 exit & $06 / 23 / 2004$ & 1308 & 6.11 \\
\hline d12 & 213411157540001 & Punaluu Ditch, $500 \mathrm{ft}$ downstream from tunnel 9 exit & $02 / 08 / 2005$ & 1452 & 5.04 \\
\hline $\mathrm{d} 12$ & 213411157540001 & Punaluu Ditch, $500 \mathrm{ft}$ downstream from tunnel 9 exit & $02 / 15 / 2005$ & 1533 & 4.69 \\
\hline $\mathrm{d} 12$ & 213411157540001 & Punaluu Ditch, $500 \mathrm{ft}$ downstream from tunnel 9 exit & $03 / 15 / 2005$ & 1301 & 5.20 \\
\hline d13 & 213414157535901 & Punaluu Ditch, tunnel 10 exit & $06 / 23 / 2004$ & 1323 & 4.23 \\
\hline d13 & 213414157535901 & Punaluu Ditch, tunnel 10 exit & $02 / 08 / 2005$ & 1627 & 2.91 \\
\hline d14 & 213415157535901 & Punaluu Ditch, tunnel 11 entrance & $02 / 08 / 2005$ & 1620 & 1.41 \\
\hline
\end{tabular}


Table 2. Discharge measurements made during 2004 and 2005 in Punaluu Ditch and Punaluu Stream and tributaries, Oahu, Hawaii, sorted by site-Continued.

[ $\mathrm{ft}^{3} / \mathrm{s}$, cubic feet per second; ft, feet]

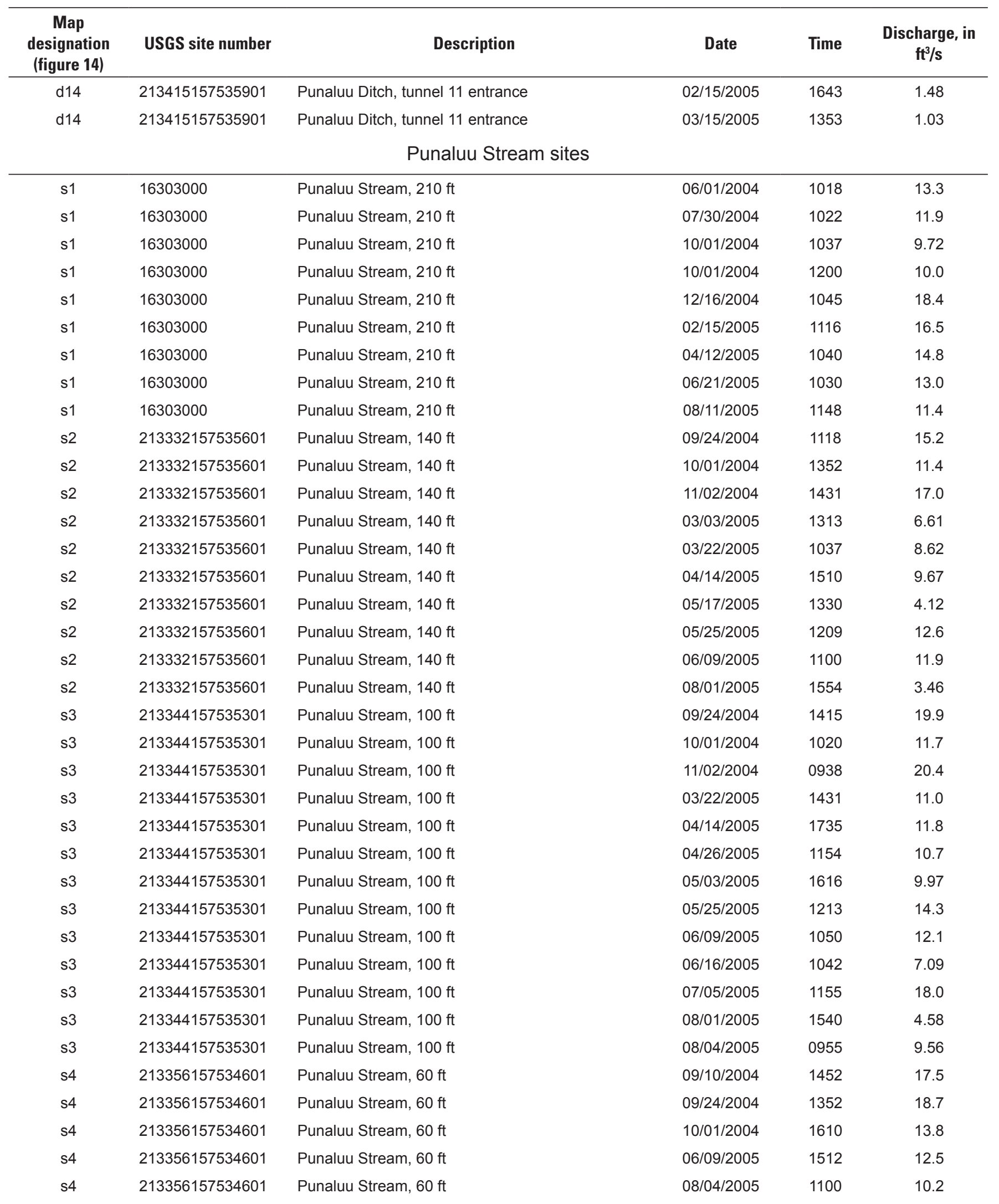


Table 2. Discharge measurements made during 2004 and 2005 in Punaluu Ditch and Punaluu Stream and tributaries, Oahu, Hawaii, sorted by site-Continued.

[ $\mathrm{ft}^{3} / \mathrm{s}$, cubic feet per second; ft, feet]

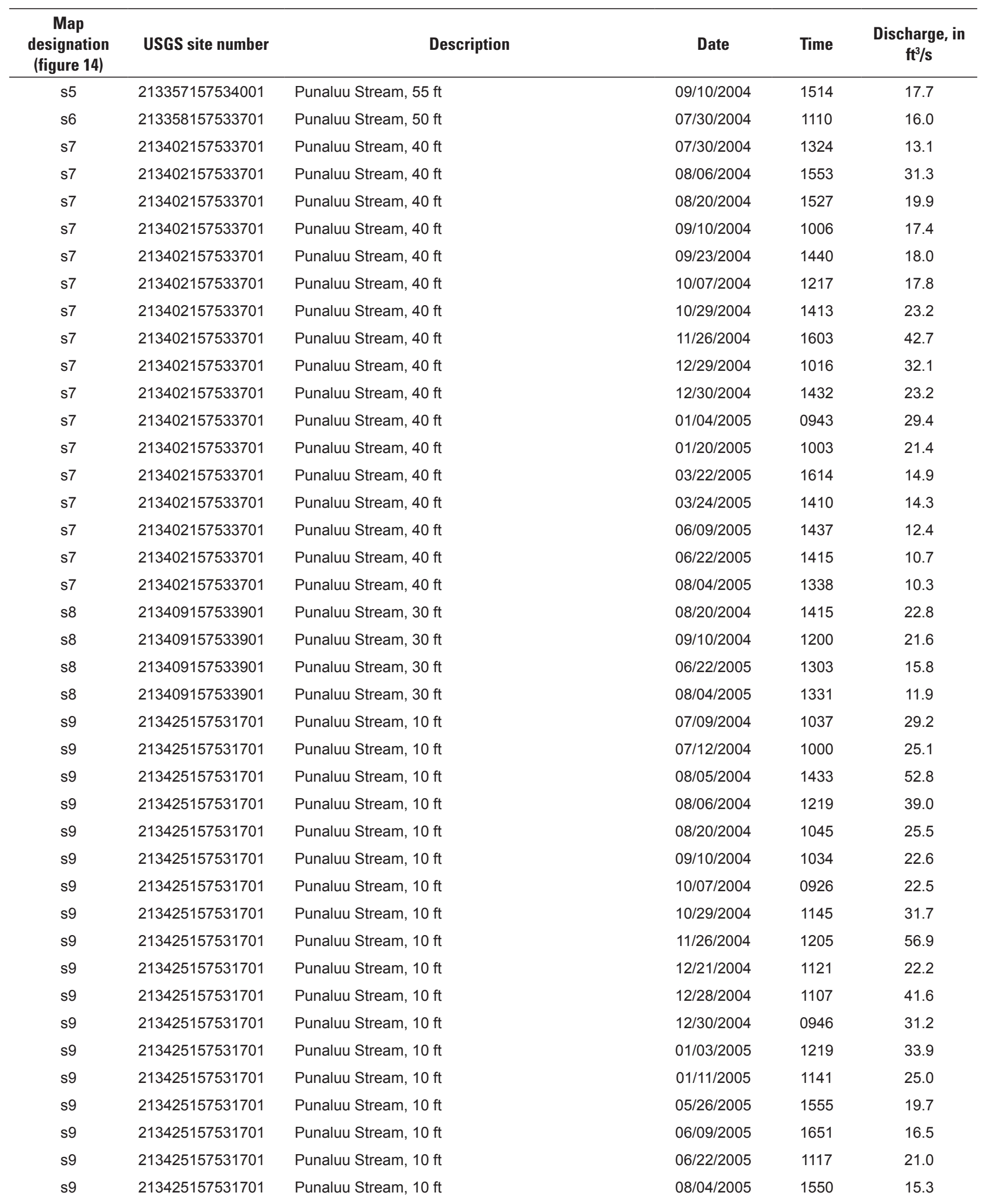


Table 2. Discharge measurements made during 2004 and 2005 in Punaluu Ditch and Punaluu Stream and tributaries, Oahu, Hawaii, sorted by site-Continued.

$\left[\mathrm{ft}^{3} / \mathrm{s}\right.$, cubic feet per second; ft, feet]

\begin{tabular}{|c|c|c|c|c|c|}
\hline $\begin{array}{c}\text { Map } \\
\text { designation } \\
\text { (figure 14) }\end{array}$ & USGS site number & Description & Date & Time & $\begin{array}{c}\text { Discharge, in } \\
\mathrm{ft}^{3} / \mathrm{s}\end{array}$ \\
\hline $\mathrm{s} 10$ & 213434157531001 & Punaluu Stream, $5 \mathrm{ft}$ & $05 / 26 / 2005$ & 1545 & 20.6 \\
\hline s10 & 213434157531001 & Punaluu Stream, $5 \mathrm{ft}$ & $06 / 09 / 2005$ & 1701 & 17.2 \\
\hline s10 & 213434157531001 & Punaluu Stream, $5 \mathrm{ft}$ & $06 / 22 / 2005$ & 1132 & 20.4 \\
\hline s10 & 213434157531001 & Punaluu Stream, $5 \mathrm{ft}$ & 08/04/2005 & 1558 & 16.3 \\
\hline $\mathrm{i} 1$ & 213333157540001 & left bank tributary, $135 \mathrm{ft}$ & 09/24/2004 & 1129 & 1.38 \\
\hline ¡1 & 213333157540001 & left bank tributary, $135 \mathrm{ft}$ & $10 / 01 / 2004$ & 1257 & 1.33 \\
\hline ¡1 & 213333157540001 & left bank tributary, $135 \mathrm{ft}$ & $11 / 02 / 2004$ & 1310 & 1.58 \\
\hline ¡1 & 213333157540001 & left bank tributary, $135 \mathrm{ft}$ & 03/22/2005 & 1219 & 1.46 \\
\hline $\mathrm{i} 2$ & 213336157535901 & left bank tributary, $125 \mathrm{ft}$ & 09/24/2004 & 1230 & 0.12 \\
\hline i2 & 213336157535901 & left bank tributary, $125 \mathrm{ft}$ & $10 / 01 / 2004$ & 1230 & 0.11 \\
\hline i2 & 213336157535901 & left bank tributary, $125 \mathrm{ft}$ & $11 / 02 / 2004$ & 1140 & 0.35 \\
\hline i2 & 213336157535901 & left bank tributary, $125 \mathrm{ft}$ & 03/22/2005 & 1300 & 0.42 \\
\hline i2 & 213336157535901 & left bank tributary, $125 \mathrm{ft}$ & $04 / 14 / 2005$ & 1707 & 0.42 \\
\hline i2 & 213336157535901 & left bank tributary, $125 \mathrm{ft}$ & 05/25/2005 & 1412 & 0.34 \\
\hline i2 & 213336157535901 & left bank tributary, $125 \mathrm{ft}$ & 06/09/2005 & 1246 & 0.12 \\
\hline i3 & 213346157535501 & left bank tributary, $95 \mathrm{ft}$ & 09/24/2004 & 1445 & 0.034 \\
\hline i4 & 213348157534901 & right bank tributary, $75 \mathrm{ft}$ & 06/09/2005 & 1300 & 0 \\
\hline i4 & 213348157534901 & right bank tributary, $75 \mathrm{ft}$ & $08 / 04 / 2005$ & 1105 & 0 \\
\hline i5 & 213352157534601 & left bank tributary, $70 \mathrm{ft}$ & 09/24/2004 & 1450 & 0.69 \\
\hline i5 & 213352157534601 & left bank tributary, $70 \mathrm{ft}$ & $10 / 01 / 2004$ & 1655 & 0.72 \\
\hline ¡5 & 213352157534601 & left bank tributary, $70 \mathrm{ft}$ & 06/09/2005 & 1255 & 0.022 \\
\hline i5 & 213352157534601 & left bank tributary, $70 \mathrm{ft}$ & 08/04/2005 & 1112 & 0.035 \\
\hline i6 & 213355157534701 & left bank tributary, $65 \mathrm{ft}$ & 09/24/2004 & 1330 & 0 \\
\hline i6 & 213355157534701 & left bank tributary, $65 \mathrm{ft}$ & $10 / 01 / 2004$ & 1600 & 0 \\
\hline i6 & 213355157534701 & left bank tributary, $65 \mathrm{ft}$ & 06/09/2005 & 1400 & 0 \\
\hline i7 & 213356157534701 & left bank tributary, $60 \mathrm{ft}$ & 09/24/2004 & 1340 & 0 \\
\hline ¡7 & 213356157534701 & left bank tributary, $60 \mathrm{ft}$ & $10 / 01 / 2004$ & 1600 & 0 \\
\hline i7 & 213356157534701 & left bank tributary, $60 \mathrm{ft}$ & 06/09/2005 & 1412 & 0.33 \\
\hline ¡7 & 213356157534701 & left bank tributary, $60 \mathrm{ft}$ & 08/04/2005 & 1016 & 0.24 \\
\hline i8 & 213405157533801 & left bank return flow, $35 \mathrm{ft}$ & 08/20/2004 & 1713 & 3.39 \\
\hline
\end{tabular}


Table 2. Discharge measurements made during 2004 and 2005 in Punaluu Ditch and Punaluu Stream and tributaries, Oahu, Hawaii, sorted by site-Continued.

$\left[\mathrm{ft}^{3} / \mathrm{s}\right.$, cubic feet per second; $\mathrm{ft}$, feet]

\begin{tabular}{|c|c|c|c|c|c|}
\hline $\begin{array}{c}\text { Map } \\
\text { designation } \\
\text { (figure 14) }\end{array}$ & USGS site number & Description & Date & Time & $\begin{array}{c}\text { Discharge, in } \\
\mathrm{ft}^{3} / \mathrm{s}\end{array}$ \\
\hline i8 & 213405157533801 & left bank return flow, $35 \mathrm{ft}$ & $11 / 26 / 2004$ & 1442 & 5.22 \\
\hline i8 & 213405157533801 & left bank return flow, $35 \mathrm{ft}$ & $12 / 30 / 2004$ & 1445 & 4.15 \\
\hline i8 & 213405157533801 & left bank return flow, $35 \mathrm{ft}$ & 08/04/2005 & 1430 & 1.62 \\
\hline i9 & 213413157532801 & right bank return flow, $17 \mathrm{ft}$, upper pipe & 09/10/2004 & 1150 & 0.13 \\
\hline i9 & 213413157532801 & right bank return flow, $17 \mathrm{ft}$, upper pipe & 06/09/2005 & 1618 & 0.59 \\
\hline i9 & 213413157532801 & right bank return flow, $17 \mathrm{ft}$, upper pipe & $06 / 22 / 2005$ & 1600 & 0.66 \\
\hline i10 & 213413157533101 & right bank return flow, $17 \mathrm{ft}$, lower pipe & $06 / 22 / 2005$ & 1600 & 1.34 \\
\hline ¡10 & 213413157533101 & right bank return flow, $17 \mathrm{ft}$, lower pipe & 08/04/2005 & 1530 & $2-3$ \\
\hline i11 & 213415157533401 & left bank tributary, $20 \mathrm{ft}$ & 09/10/2004 & 1200 & 0 \\
\hline i11 & 213415157533401 & left bank tributary, $20 \mathrm{ft}$ & $08 / 04 / 2005$ & 1530 & 0 \\
\hline i12 & 213416157532401 & right bank tributary, $15 \mathrm{ft}$ & $09 / 10 / 2004$ & 1142 & 0.01 \\
\hline ¡12 & 213416157532401 & right bank tributary, $15 \mathrm{ft}$ & 08/04/2005 & 1535 & 0 \\
\hline
\end{tabular}

